\title{
Effects of Administrative License Revocation on
}

\section{Employment}

\section{May 1996}

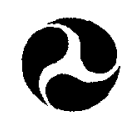

U.S. Department of Transportation National Highway Traffic Safety Administration 
This publication is distributed by the U.S. Department of Transportation, National Highway Traffic Safety Administration, in the interest of information exchange. The opinions, findings, and conclusions expressed in this publication are those of the author(s) and not necessarily those of the Department of Transportation or the National Highway Traffic Safety Administration. The United States Government assumes no liability for its contents or use thereof. If trade or manufacturers' name or products are mentioned, it is because they are considered essential to the object of the publication and should not be construed as an endorsement. The United States Government does not endorse products or manufacturers. 


\section{PREFACE}

This research project evaluated both the effects of administrative license revocation (ALR) on the employment of first and multiple DUI offenders and the effects of alcohol-involved crashes on the employment of the victims of these crashes.

The authors would like to recognize the following organizations (and contact individuals) for their .assistance with the DUI offender questionnaire by allowing KETRON team members to administer surveys to DUI offenders in their education/treatment programs: Delaware Safety Council, Inc. (Mr. Christopher Massaferi), Delaware Drinking Driver Program (Mr. Bruce Lorenz), Alcohol and Drug Recovery, Ltd. (Mr. Barry Wilen), Health Management Enterprises, Inc. (Mr. Stephen Buchness), Recovery Center of Annapolis (Dr. John McClanahan), Chester County (PA) Council on Addictive Diseases, Inc. (Mr. Robert Esty), and Marin County Drinking Driver Program (Dr. Joan Driscoll).

The victim questionnaire administration was only possible as a result of the assistance of the following organizations and contact individuals: Delaware State Police (Captain Doug Hancock and Ms. Tammy Hitchens), California Department of Motor Vehicles (Mr. Ray Peck, Mr. Cliff Helander, and Ms. Patrice Rogers), and Chester County, PA District Attorney's Office (Mr. Nick Casenta).

The authors would also like to thank Mr. Steven Schmidt, formerly of the PA DUI Association, for his assistance throughout the project and the following KETRON team members who assisted with site selection and recruiting, survey development, survey administration, and impact analysis: Mr. Lawrence Decina, Dr. Michael Temple, Ms. Marta BlotnyKornak, and Mr. William Dreifke.

Finally, a special thanks goes to Ms. Julee Shuck for the production of the task and final reports for this project. 
Technical Report Documentation Page

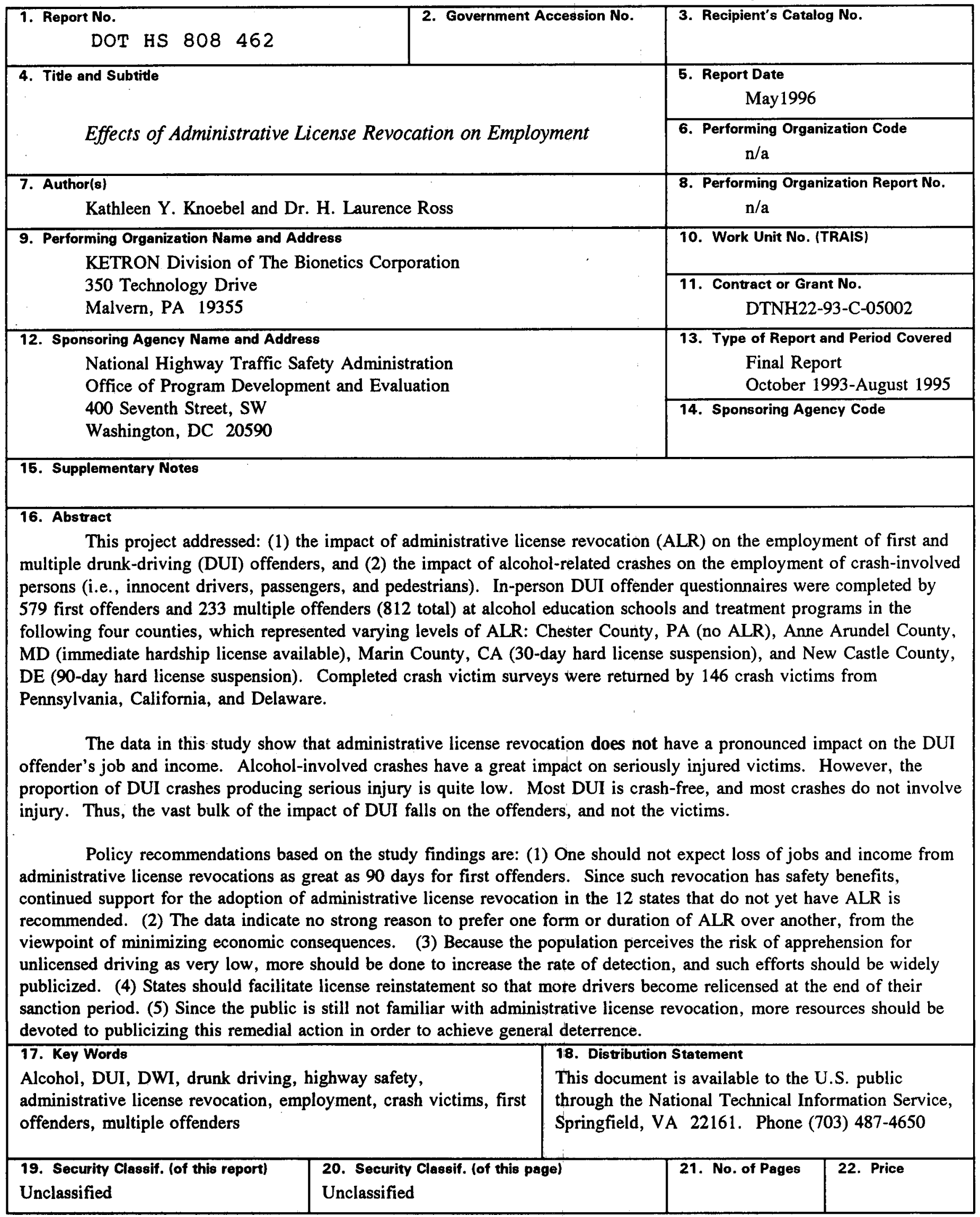

Form DOT F 1700.7 (8-72)

Reproduction of completed page authorized 


\section{TABLE OF CONTENTS}

\section{Section \& Title}

Page

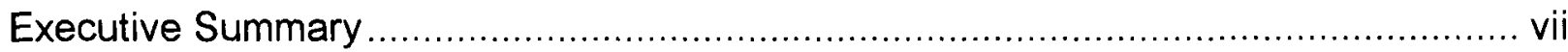

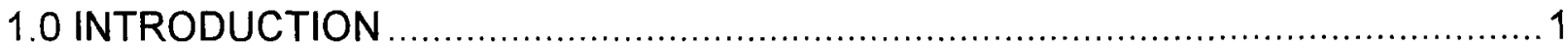

1.1 Background on Administrative License Revocation ..................................... 1

1.2 The Benefits of Administrative License Revocation ........................................... 3

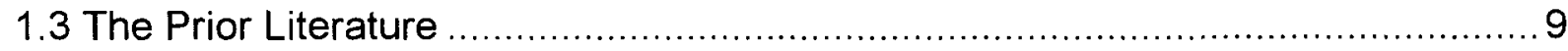

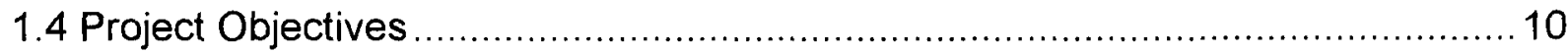

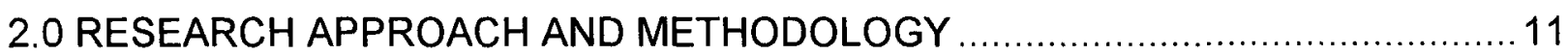

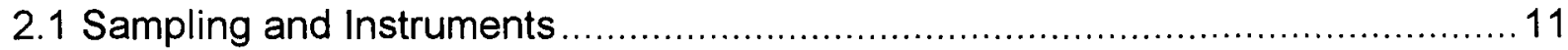

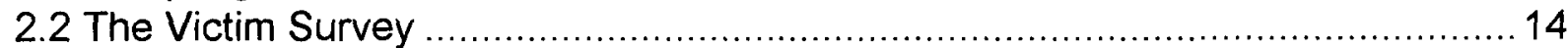

2.3 DUI Offender Survey Administration ............................................................ 14

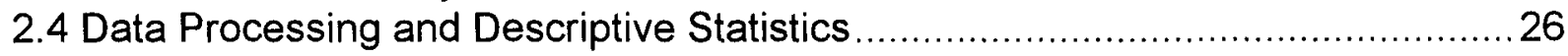

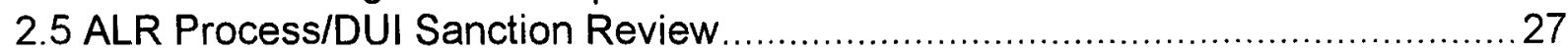

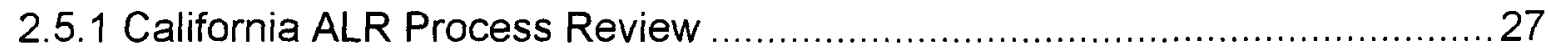

2.5.2 Delaware ALR Process Review.............................................................. 30

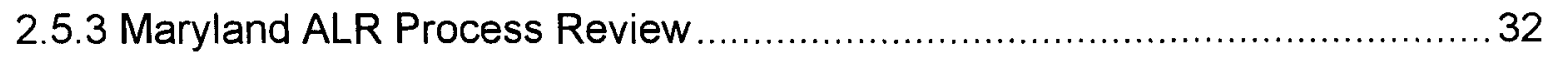

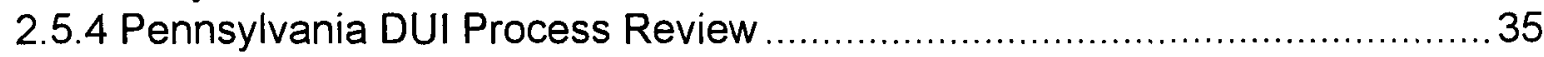

2.6 Methodology for Estimating Impact on Employment .......................................37

3.0 ANALYSIS AND INTERPRETATION OF RESEARCH FINDINGS .....................39

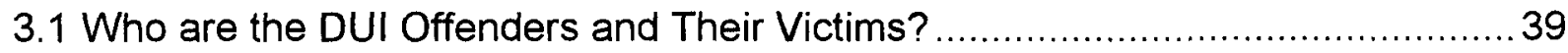

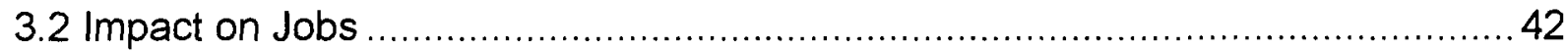

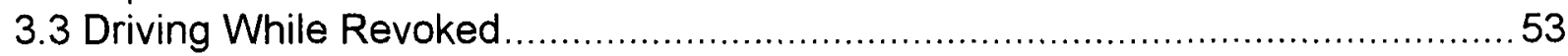

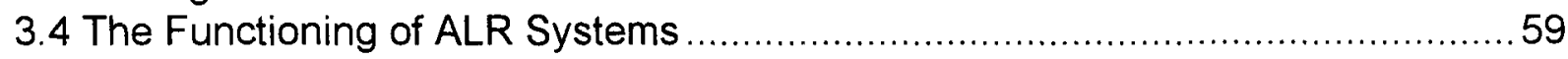

3.5 Other Findings Related to Safety Among DUI Offenders .................................6. 65

3.6 Administration of Surveys to Spanish Speaking DUI Offenders .......................70

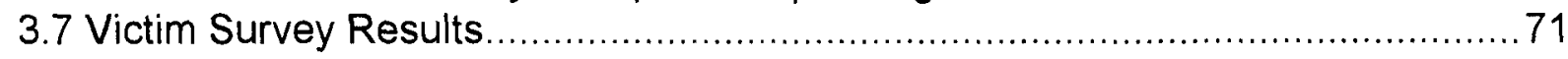

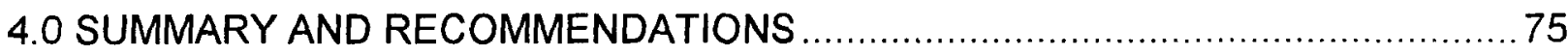

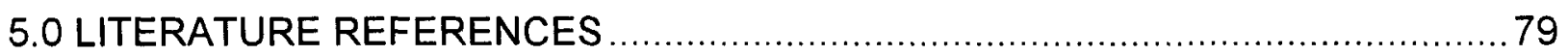

\section{APPENDIXES}

A - DUI Offender Questionnaire for ALR States

B - Spanish-Version of DUI Offender Questionnaire for ALR States

C - Alcohol-Related Crash Victim Cooperation Letters and Survey

D - DUI Offender Survey Statistical Tabulation by State and DUI Offender Type

E - Alcohol-Related Crash Victim Survey Statistical Tabulation by State and

Treatment of Injuries

F - Evaluation Design for Estimating Impact on Employment 


\section{List of Figures}

Figure

Page

1-1 Length of Mandatory License Suspension by State ............................................ 8

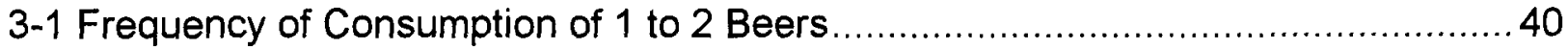

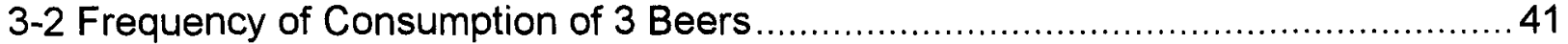

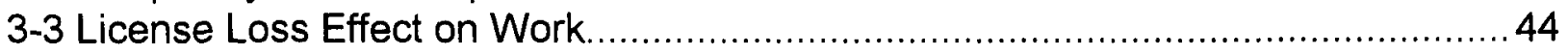

3-4 Impact Analysis of ALR on First Offender Income.............................................4

3-5 Impact Analysis of ALR on Multiple Offender Income .......................................48

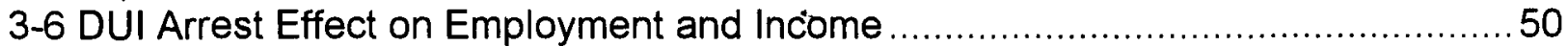

3-7 DUI Crash Victim Employment and Income Changes ........................................5 52

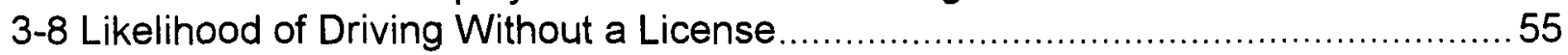

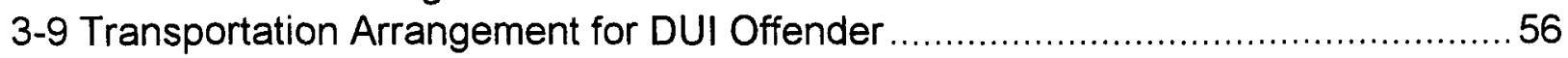

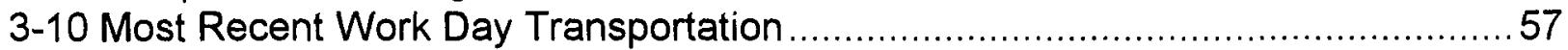

3-11 Likelihood of Being Caught Driving Unlicensed ...............................................5

3-12 Percent DUI Offenders Who Did Not Take Breath Test....................................6 60

3-13 Percent of DUI Offenders Who Did Not Take Breath Test Who Were Charged With Refusing Breath Test ............................................................................60

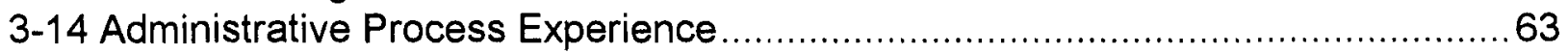

3-15 Awareness of Administrative Process Before DUI Arrest...................................63

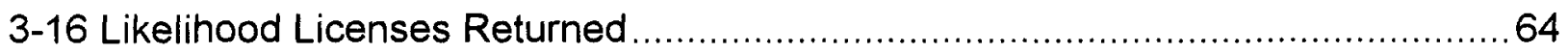

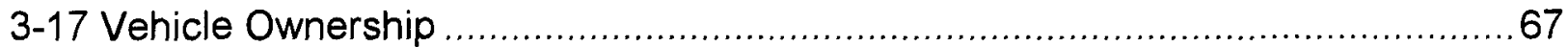

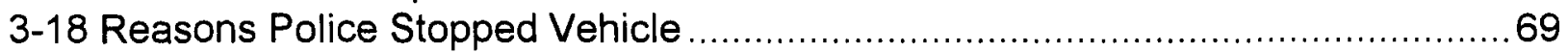

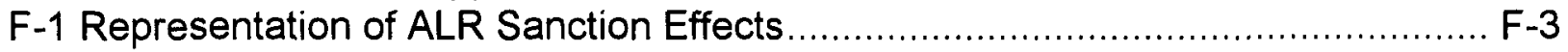




\section{List of Tables}

Table

Page

1-1 Status of Administrative License Revocation by State .......................................... 4

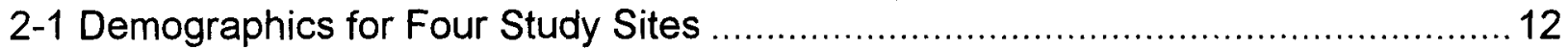

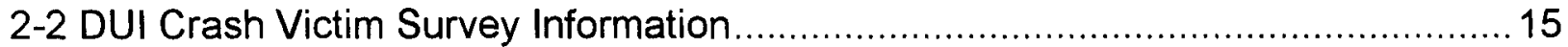

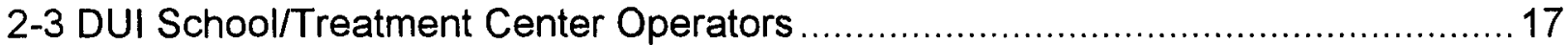

2-4 DUI Offender Survey Administration Schedule ................................................. 24

3-1 Characteristics of DUI Offenders, Crash Victims, and the General

Population in the Four Study Sites

3-2 Frequency of Consumption of One to Two Beers/Mixed Drinks/Glasses Wine

Less Than 1 Hour Before Driving During the 12 Months Prior to DUI Arrest..........40

3-3 Frequency of Consumption of Three Beers/Mixed Drinks/Glasses Wine

Less Than 1 Hour Before Driving During the 12 Months Prior to DUI Arrest..........41 41

3-4 Extent Loss of License Has Interfered With Work ...............................................44

3-5 Extent Loss of License Has Interfered With Work by Need for Vehicle/License .... 45

3-6 First Offender Income Impact After DUI Arrest................................................4 47

3-7 Multiple Offender Income Impact After DUi Arrest ............................................48

3-8 Difference in Percent Reduction in Income Between ALR and Non-ALR States ....49

3-9 Stated Changes in Employment and Income as a Result of the DUI Arrest............50

3-10 Activity the Month After DUI Arrest for Those Working the Month Before

Arrest

3-11 Stated Changes in Employment and Income as a Result of DUI Crash...............52

3-12 Activity the Month After DUI Crash for Those Working the Month

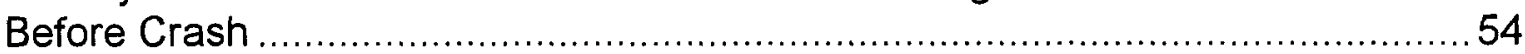

3-13 DUI Offender's Likelihood of Driving Without a License ..................................55

3-14 DUI Offender's Transportation Arrangements for Work While Waiting for

License Reinstatement................................................................................56

3-15 Method of Transportation for DUI Offender's Most Recent Day of Work ...............57

3-16 Likelihood of Being Caught for Those DUI Offenders Who Drive Without

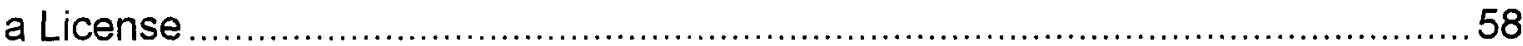

3-17 DUI Offender Experience With the Breath Test at Time of Arrest......................59

3-18 Experience/Knowledge of DUI Offenders With the Administrative

Process

3-19 Likelihood DUI Offender Will Get License Back When Suspension/

Revocation Ends 64

3-20 DUI Offenders With Valid License at Their Most Recent DUI Arrest ....................65

3-21 Prior DUI Arrest Records.........................................................................6. 65

3-22 DUI Offenders Who Reported Wearing Seat Belt at the Time of DUI Arrest .......66

3-23 Ownership of the Vehicle Driven at the Time of DUI Arrest .............................67

3-24 Reason Police Stopped Vehicle at the Time of DUI Arrest ...............................68

3-25 Number Currently Employed Household Members of the DUI Offender ...............69

3-26 Involvement of Victims in the DUI Crash....................................................

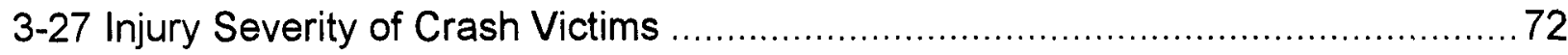




\section{List of Tables (Continued)}

Table

Page

3-28 Damage to Vehicle Resulting from DUI Crash ..................................................73

3-29 Comparison of Crash Victim Survey and DUI Offender Survey Results ..............74 


\section{EXECUTIVE SUMMARY}

\section{PROJECT OBJECTIVES AND BACKGROUND}

This report presents the results of a study of drunk-driving (DUI) offenders in four jurisdictions which differ in the driver-license consequences of failing and refusing alcohol breath tests. The three main objectives of this research project were to:

1. Determine the impact of short-term (30-45 days) administrative license suspension/revocation on the emplöyment and income of first offenders.

2. Determine the impact of longer-term ( 6 months to a year) administrative license suspension/revocation on the employment and income of multiple offenders.

3. Determine the effects of alcohol-related crashes and injuries on the employment and income of other crash-involved persons (i.e., innocent drivers, passengers, and pedestrians).

The administrative license revocation (ALR) process constitutes taking a driver's license administratively, rather than judicially, based on evidence provided by the police that the driver was impaired by alcohol. This differs from the traditional use of license revocation as a criminal sanction. Traditionally, license revocation was one of several possible remedial actions available to a judge for sentencing someone found guilty of drunk driving or, in more recent years, someone found guilty of driving with a blood/breath alcohol content (BAC) exceeding a tolerated limit, usually 0.10 percent. Criminal license penalties could only be imposed after final judgment, rendering them contingent on successful prosecution. Criminal prosecution required proof beyond a reasonable doubt that the defendant had committed the offense charged. The mechanics of this process substantially weakened license actions in terms of the swiftness and certainty of application.

The prior research literature supports the view that ALR is effective in reducing alcohol-involved driving. However, an important concern with this issue is ALR is not universal in the United States. As of January 1996, ALR laws were in effect in 38 states and the District of Columbia. Among the principal rationales offered by the remaining 12 states for rejecting ALR is the claim that license revocation leads to loss of employment, in turn impacting on the offender's dependents and subsequently societal welfare costs

On this topic, prior literature has found that income and employment losses are experienced by only a small minority of persons losing their licenses as a consequence of DUI. Among the reasons that can be cited are: (1) some important fraction of workers do not commute, but earn their income by working at home or walking to work; (2) some are able to substitute alternative means of getting to work, such as car pooling or using public transportation; and (3) some evade the remedial actions by 
driving without licenses. The current study investigated the extent to which these alternatives are realized.

Despite the evidence in favor of administrative license revocation for DUI offenders, as of January 1996, there are still 12 states that do not have ALR laws. Although the research in Delaware, New Mexico, Arizona, and Mississippi indicates that the effect of ALR on employment is minimal, the research is thin in this area. In the absence of quantitative data regarding the actual effects of ALR on employment, it is impossible to know whether the perceived draconian effect on employment actually occurs for an important fraction of DUI offenders.

Therefore, in order to examine the actual effect of ALR on the employment of DUI offenders and the victims of crashes associated with these offenders, NHTSA funded the current research project. The results of this research provide NHTSA with information to present to states that are considering enacting ALR laws.

\section{RESEARCH APPROACH AND METHODOLOGY}

\section{Site Selection}

Current ALR laws vary widely by state. The states can be characterized as falling into one of the following four categories:

1. No Laws. The driver's license can only be suspended after a criminal conviction.

2. ALR/Immediate Hardship License. A hardship license (e.g., for employment) can be obtained for the duration of the suspension period, with no mandatory "hard" suspension period.

3. ALR/30-60 Day Mandatory Suspension. The license suspension period is typically 90 days, but a hardship license can be obtained after a full or "hard" suspension period of 30-60 days. However, there is a short period after the DUI arrest when the DUI offender has a temporary license so that transportation arrangements can be made.

4. ALR/90+ Day Mandatory Suspension. A "hard" suspension period of at least 90 days is prescribed.

The study was designed to investigate the consequences of license revocation by choosing jurisdictions representing the four legal categories. In Delaware, ALR for 90 days is automatic for persons arrested for DUI and failing the mandated breath test. In California, although a suspension period of 120 days is prescribed, hardship license's are available after 30 days. In Maryland, a DUI offender has a formal suspension period of 45 days, but can receive a hardship license without any period of "hard" 
suspension. The fourth state, Pennsylvania, represents non-ALR jurisdictions. In Pennsylvania, there are no mandated consequences for failing a breath test at the scene of an arrest; it is not until a suspect is convicted that the possibility of license revocation arises. These four cases represent the range of license revocation provisions generally used for DUI.

In order to appreciate any impacts that might be found, the study was designed to compare employment and income effects of license revocation on DUI offenders with the employment and income effects of injury-producing DUI crashes on victims, pedestrians, non-impaired drivers, and their passengers.

A problem with comparing different jurisdictions is that the law is not the only thing that differentiates them. One can expect differences in climate, demography, the economy and, most generally, culture. A problem arises in interpreting whether differences found between the jurisdictions are caused by the variables by which they were selected.

The approach used to control for these factors was to select jurisdictions with different laws but similar socio-demographics and proximate locations. Three of the four states were contiguous: Pennsylvania (without ALR), Maryland (with immediate hardship licenses), and Delaware (with 90 days "hard" suspension). From each of these states, one county was selected on the basis of physical and social similarity to the others. The counties were Chester, Anne Arundel, and New Castle, respectively.

These jurisdictions did not provide an example of a state making hardship licenses available after 30 days. Indeed, there are none contiguous to the three mentioned above. Because of its excellent statistical system and cooperative officials, California was selected as a comparison state. It lacks contiguity, but Marin County is socio-demographically similar to the other sample counties.

\section{DUI Offender Survey}

Prior experience with similar research suggested that random sampling from state records of the DUI population would not succeed in reaching DUI offenders. Therefore, subjects were drawn from DUI treatment and education programs. In each of the four selected counties, all programs providing services to DUI offenders were located and requested to cooperate in allowing their classes or treatment groups to complete a paper-and-pencil questionnaire.

A questionnaire was designed for classroom administration. Once it was discovered that both California and Pennsylvania institutions offered classes for Spanish-speaking people, the questionnaire was translated into Spanish for use with these special classes and anyone else who indicated a preference. (Unfortunately, the Hispanic sample, largely Mexican immigrants, frequently proved to be illiterate in 
Spanish as well as English, and it was not possible to complete a planned analysis of them.)

DUI schools/treatment programs in all four counties agreed to participate in the datacollection activities. In Chester County, Pennsylvania, the one facility that runs both first offender and multiple offender programs participated. In Anne Arundel County, Maryland, three facilities participated, covering both first and multiple offenders. Also in Marin County, California, the one facility that offers both first offender and multiple offender programs agreed to participate. In New Castle County, Delaware, one first-offender DUI school (serving New Castle County only) and one multiple-offender DUI program (serving all of Delaware) participated.

The project goal was 200 interviews in each county--150 with first offenders and 50 with multiple offenders. It was estimated that this distribution would mirror the split between first offenders and multiple offenders among those convicted of DUI offenses. Data collection spanned the period from June 1, 1994 to October 6, 1994. A total of 812 completed DUI offender surveys were used for the final analysis--579 with first offenders and 233 with multiple offenders.

\section{Crash Victim Survey}

A comparison group of victims was selected, defined as people other than the impaired drivers involved in alcohol-related injury crashes in the same counties. These were largely unimpaired drivers of other cars, along with some passengers and pedestrians. Victims thus defined are a difficult group to find and study. In California and Delaware, state records were used to identify qualifying crashes in the respective counties, from about the time that the DUI offenders were apprehended. For reasons of confidentiality, state officials hired clerks to identify appropriate persons, and send them questionnaires based on items from the DUI offender instrument. A victim population could not be identified in Maryland.

In Pennsylvania, the state proved unable to provide appropriate files, so DUI arrest records from the District Attorney's Office in Chester County were scanned to locate those that involved crashes. The crash reports were then read to extract the names and addresses of third parties (victims) involved in these crashes, to whom questionnaires were sent.

It was assumed that victims had a story they would want to tell and that endorsement by the state would produce high response rates, but a surprisingly low response rate was obtained--58 of 189 surveys (32 percent) were returned in Delaware, 34 of 192 surveys (19 percent) were returned in California, and 54 of 182 surveys ( 32 percent) were returned in Pennsylvania. 


\section{RESEARCH FINDINGS}

\section{Who are the DUI Offenders and Their Victims?}

As has been found in other studies, the DUI offenders were atypical of the general population. Even first offenders differ socio-demographically from the general population, and the multiple offenders were even less representative. DUI offenders are disproportionately male, living without families, less educated, and more working class, than either the victims or the general population. As mature men, they are very likely to be employed and to be susceptible to factors impinging on employment. Beyond this, it appears that the DUI offenders, especially the multiple offenders, are heavy drinkers in conjunction with driving.

However, DUI offenders are not importantly different from victims (or the general public) in average age and in racial composition.

The victim populations are socio-demographically close to the general population, a finding that might be expected in an auto-dependent society if victimization merely depends on using the public roads.

\section{Impact on Jobs for DUI Offenders}

In brief, expectations that earnings of DUI offenders in ALR states should be reduced when compared to the non-ALR state were not confirmed by most of the analyses. This central question was examined in numerous ways for both DUI offenders and crash victims.

First, the offenders were asked to rate the extent that their loss of license has interfered with work (for those offenders who were working at the time of the DUI arrest). Nearly half the offenders reported that the experience greatly interfered with their work. These were mostly people who claimed that their jobs required the use of a car, whether for commuting or even more so, for those using a car in their work. Multiple offenders were in general more likely to report a great extent of interference than were first offenders, as might be expected given the heavier license penalties reported by this group. However, there does not seem to be an orderly pattern of responses among the states and therefore among different kinds and lengths of ALR.

Second, the offenders were asked to report income for the jobs they held from 1992 to 1994. An impact analysis was performed for first and multiple offenders which compared the change in income after DUI arrest for DUI offenders in each of the ALR states to the change in income after DUI arrest for DUl offenders in the non-ALR comparison state. The impact analysis regression model controlled for the effect of the DUI offender being in jail or attending school in any given month, as well as the expected increase in monthly income over time. Monthly impact measures/significance levels were obtained for the 6 months after DUI arrest for three separate models (for 
both first and multiple offenders): Maryland versus Pennsylvania, California versus Pennsylvania, and Delaware versus Pennsylvania.

For first offenders, the earnings comparison between Delaware and Pennsylvania was not significant, though in the same direction as that presented in the hypothesis (income was reduced more in the ALR state when compared to the nonALR state). There was no significant impact on earnings for multiple offenders, and the differences were in the opposite direction from that presented in the hypothesis (postarrest income was higher in the ALR state than in the non-ALR state). The same patterns and lack of significance were found when offenders in Maryland were compared with those in Pennsylvania. The impact analysis for California first offenders showed a significant gain against Pennsylvania in earnings. No significant effect was noted for California multiple offenders in the first several months after arrest.

Third, the offenders were asked how much income they lost per week as a direct result of their DUI arrest/loss of license. The percent reduction in income from the income reported for the month of the DUI arrest was computed for all offenders (where available). A t-test of difference between the percent reduction in each of the three ALR states and the percent reduction in the comparison non-ALR state was performed for both first and multiple offenders to determine whether the percent reduction was significantly greater in the ALR states. None of these six tests was significant at the $5 \%$ level.

Fourth, the offenders were asked to describe the effect of their most recent arrest on their employment. These open-ended responses were coded into categories and summarized. Over 55 percent of the respondents stated there was no change in their employment or income after the DUI arrest.

Fifth, the activity the month after arrest was examined for those offenders who were working the month before their arrest to determine whether changes in employment were more pronounced in ALR states when compared to the non-ALR state. The percent still working the month after arrest (94 percent) was identical for DUI offenders in the three ALR states and the non-ALR state.

Finally, a regression analysis was performed to predict income based on multiple explanatory variables to determine whether there was a strong relationship between income and ALR status. The regression analysis found strong significant relationships with gender, marital status, age, and education, but not with the state of residence (and therefore, probably not with ALR status).

\section{Impact on Jobs for DUI Crash Victims}

Membership in the victim group was defined in terms of unimpaired survivors of alcohol-related crashes. Even though this analysis compared people who were in crashes with a broader group of DUls, most of whom were not in crashes, the evidence does not 
support the idea that the employment of victims is more impacted than that of the DUI offenders. Victims seldom reported a disability-related change in jobs--only 6 of 146 made this claim, and it was not necessarily the case that the disability was related to the victimization

When the crash victims were asked to describe the impact on their employment that resulted from involvement in the alcohol-related crash, over 56 percent reported no impact. It is important to note that, assuming self-selection bias, the more seriously injured/impacted crash victims would have been more likely to return the questionnaire.

The crash victims were asked how much income they lost per week as a direct result of their DUI crash. The percent reduction in income from the income reported for the month of the DUI crash was computed for all DUI crash victims (where available). A t-test of difference between the percent reduction for DUI offenders and the percent reduction for DUI crash victims was performed to determine whether the percent reduction was significantly greater for victims or offenders. The percent reduction was actually greater for offenders (12.0 percent) compared to DUI crash victims (7.6 percent). However, this difference was not significant at the $5 \%$ level.

The activity the month after the DUI crash was examined for those crash victims who were working the month before their crash to determine whether changes in employment were more pronounced when compared to DUI offenders. The percent still working the month after the crash was less for the victims (71 percent total) compared to the offenders ( 94 percent total).

\section{Driving While Revoked}

Although the respondents frequently claimed interference with work from the DUI and license revocation, many of them admitted to driving to work and for other social functions. Particularly in the ALR states, large numbers of informants rated the probability that they would drive without a license as very likely, reaching nearly twothirds for California multiple offenders.

Important numbers of DUI offenders who lost their license stated that they drive to work. The figure was higher in Maryland and California, where hardship licenses are available, but even in Delaware, a fifth of first offenders and one in seven multiple offenders declared that they continued to drive to work. More than a third of respondents reported that they drove on the most recent day they worked. When all occasions for travel are considered for those DIU offenders without a license, 46 percent admitted that they drove themselves ( 48 percent of first offenders and 41 percent of multiple offenders).

Driving while unlicensed is likely to be encouraged by the belief that there is little danger of being caught. Majorities of both first and multiple offenders rated the risk as 
low, and only seven percent of the sample said that being caught is very likely during a month of unlicensed driving.

\section{The Functioning of ALR Systems}

A small proportion of DUI offenders did not take breath tests at the time of arrest. Except in California, the proportions were higher for repeat offenders, representing almost half in Maryland. One would have expected (as is the case for Maryland) that a large percent of DUI offenders who did not take a breath test at the time of arrest would have been charged with refusing the breath test. However, this was not the case as less than 35 percent of those who did not take a breath test were charged with test refusal in the other three states.

Nearly a third of first offenders were ignorant of the possibility of administrative license revocation at the time of their offense. This was also true of one out of six multiple offenders. Such people obviously could not have been deterred by the ALR law. Among the ALR states, Maryland produced the highest proportion of demands for hearings, with more than half requesting them. Maryland drivers also more frequently attended the hearings and were more frequently rewarded by getting their licenses returned.

DUI offenders expect to become relicensed. However, nontrivial proportions of multiple offenders indicated a low probability of relicensing.

\section{Other Findings Related to Safety Among DUI Offenders}

On average, 2 percent of first offenders and 21 percent of multiple offenders were driving while unlicensed at the time of their arrest. Many repeat offenders (nearly one in six) had more than one prior offense on their record in the past year, and declared priors were as high as five in 5 years.

Multiple offenders were more likely to fail to wear seat belts ( 40 percent for multiple offenders versus 30 percent for first offenders). This accords with the understanding that repeat DUI offenders tend to engage in other unsafe driving behaviors. Registration of vehicles in the name of persons other than the DUI offender was relatively uncommon, even for multiple offenders. Approximately 20 percent were registered in the name of someone who did not live in the same household. It was expected that this would occur as a means of avoiding insurance surcharges, but the expectations were disconfirmed.

Crashes accompanied 17 percent of all DUI arrests. The vast bulk of arrests were based on moving violations (66 percent) or equipment violations ( 8 percent). One implication of this fact is that the experiences of DUI offenders as a group are incommensurate with those of crash victims. 
Most offenders (67 percent) lived in households with other employed persons. One implication of this is that even if the DUI offender were to lose his/her employment, most of the households would be able to count on the income of others for survival.

\section{Administration of Surveys to Spanish Speaking DUI Offenders}

Another finding of this research study was that the needs of Spanish speaking DUI offenders may not be adequately addressed by current alcohol education and treatment programs. This group is very different from the DUI offenders for whom English is the primary language, in terms of culture, education, employment, and driving experience. The Spanish version of the DUI offender questionnaire, which was developed for administration in the special classes conducted in Spanish in two states, met several obstacles in practice. In the end, the attempt was abandoned when it turned out that members of the target group were often illiterate in Spanish as well as English, and were not able to complete a paper-and-pencil survey on their own. Also, some components of the questionnaire were foreign to the Hispanic classes.

The Spanish speaking respondents raised the problem that our definition of jobs and employment does not correspond with the understanding of some segments of society. Many of the Mexican immigrants in the sample worked at a different "job" every day. Furthermore, many of the Hispanics never possessed a driver's license and thus could not have been greatly influenced by that sanction. The questions concerning license revocation made little sense to them. Other, similar, problems were discovered, such as the fact that many Spanish speakers in Pennsylvania lived in company dormitories and lacked understanding of the journey to work.

\section{Victim Survey Results}

The results are for a relatively small sample of victims (approximately 150) and they represent a very small percentage of the injuries in alcohol-related crashes. The majority of the injuries are suffered by the DUI offenders who cause these crashes. Over 75 percent of the victims were drivers of another vehicle involved in the crash (but not charged with DUI). Over 27 percent were uninjured and nearly half did not require medical treatment. Only about 15 percent required hospitalization. Most of the damage was to vehicles; more than 57 percent of the crash victims reported that their vehicle was damaged such that it could not be driven away from the crash scene.

The results from the crash victim survey were compared with comparable results from the DUI offender survey. Ten percent fewer crash victims were employed at the time of their DUI crash as compared to DUI offenders employed at the time of their DUI arrest. A larger percent of crash victims was employed in professional jobs than DUI offenders. The average tenure of crash victims at their current job was 8 months longer than the average tenure of DUI offenders at their current job. The DUI offenders worked more hours per week and earned slightly more per week than the crash victims. Both groups reported an 
almost identical weekly reduction in income (under $\$ 100 /$ week) as a result of the DUI crash or loss of license.

\section{SUMMARY AND RECOMMENDATIONS}

The data in this study show that administrative license revocation does not have a pronounced impact on the DUI offender's job and income. An important reason for this is the willingness of these offenders to continue driving, although presumably more safely than they did when licensed. DUI offenders view the risk of apprehension as low. The main employment consequence of license revocation on DUI offenders is the need to find alternative transportation, which is generally achieved by riding with others. Offenders see this as an inconvenience, but lost income is uncommon.

Alcohol-involved crashes have a great impact on seriously injured victims. However, the proportion of DUI crashes producing serious injury is quite low. Most DUI is crash-free, and most crashes do not involve injury. Thus, the vast bulk of the impact of DUI falls on the offenders and not the victims.

Some important experience regarding the study of offenders was obtained during the course of this project. The method of surveying offenders at alcohol highway safety schools and alcohol treatment programs worked very well for both first and multiple offenders literate in English. The schools and treatment programs were interested in the research study and were therefore cooperative and accommodating of the survey requirements. A very high survey participation rate was obtained from the offenders.

This research has also found that administrative license systems differ in their efficiency. In some places, represented by Maryland, hearings are almost routinely requested and they often result in return of the license. In others, including both California and Delaware, few requests are made and few are successful in canceling the penalty. A partial explanation may be found (as in Delaware) in the policy of demanding police attendance at hearings and restoring the license of drivers if police do not attend.

Policy recommendations based on these findings are:

1. One should not expect loss of jobs and income from administrative license revocation periods as great as 90 days for first offenders. Since such revocation has safety benefits, continued support for the adoption of administrative license revocation policies is recommended.

2. The data indicate no strong reason to prefer one form or duration of ALR over another, from the viewpoint of minimizing economic consequences. 
3. Because the population perceives the risk of apprehension for unlicensed driving as very low, more should be done to increase the rate of detection, and such efforts should be widely publicized.

4. States should facilitate license reinstatement at the end of the sanction period to encourage drivers to reenter the licensing system.

5. Since the public is still not familiar with administrative license revocation, more resources should be devoted to publicizing this remedial action in order to achieve general deterrence.

The following additional research is suggested:

1. Further research is needed to determine whether driving would be further reduced with vehicle sanctions, i.e., policies designed to separate would-be drunk driving offenders from access to vehicles.

2. The direct economic impact of the DUI conviction in the matter of fines, legal expenses, program fees, and insurance surcharges should be studied. These costs are quite likely to exceed the income impacts investigated in this report.

3. More is needed on enforcing the prohibition of driving while suspended or revoked.

4. The population in this study very largely declares expectations of becoming relicensed. A panel study might follow a set of unlicensed drivers over time to check when and how they achieve relicensing, and compare those who do get licensed with those who do not in terms of subsequent driving history. 


\subsection{INTRODUCTION}

This report presents the results of a study of drunk-driving (DUI) offenders in four jurisdictions, which differ in the driver-license consequences of failing and refusing breath tests. Its main concern was to evaluate the extent to which these consequences affect the employment and income of DUI offenders.

An important basis for concern with this issue is that adoption of administrative license revocation (ALR), increasing the probability and swiftness of removing the offending driver from the road, is not complete in the United States. Among the principal rationales offered for rejecting this measure is the claim that license revocation leads to loss of employment, in turn impacting on the offender's dependents and subsequently on societal welfare costs. This claim cannot be rejected out of hand, and to the extent that it is valid it suggests the need to balance these consequences against the benefits of revocation in terms of incapacitating and reforming the offenders and deterring others.

\subsection{Background on Administrative License Revocation}

As of January 1996, administrative license revocation (ALR) laws were in effect in 38 states and the District of Columbia. Adoption of such laws is being urged on the remaining states by numerous organizations devoted to reducing drunk driving, most notably the National Highway Traffic Safety Administration (NHTSA), which has drafted a model statute and offers funding incentives for the states passing conforming legislation. The first ALR law was enacted in 1976 in Minnesota (major amendments to Minnesota's statutes were passed in 1978 and 1982).

The ALR process constitutes taking a driver's license administratively, rather than judicially, based on evidence provided by the police that the driver was impaired by alcohol. This differs from the traditional use of license revocation as a criminal sanction. Traditionally, license revocation was one of several possible remedial actions available to a judge for sentencing someone found guilty of drunk driving or, in more recent years, someone found guilty of driving with a blood/breath alcohol content (BAC) exceeding a tolerated limit, usually 0.10 percent. Criminal license penalties could only be imposed after final judgment, rendering them contingent on successful prosecution. Criminal prosecution required proof beyond a reasonable doubt that the defendant had committed the offense charged. The mechanics of this process substantially weakened license actions in terms of the swiftness and certainty of application.

Administrative revocation developed in stages, initially as a means to induce cooperation of drivers in taking breath-alcohol tests by enforcing the driver's "implied consent" to be tested. People using the roads, it was argued, had by implication consented to cooperation with the alcohol test. Today, administrative revocation permits the police to temporarily remove the license on the basis of evidence that the driver may be unsafe. 
This evidence is supplied by a positive reading on a test of alcohol impairment or by refusal to take the test when there is reasonable cause to believe that the driver is impaired.

The driver's license is taken or altered on the spot, and the driver is notified that his/her permission to drive will expire in a given number of days. A temporary driving permit, valid for a limited number of days, is then issued. Each state has statutory provisions that define the process leading back to reinstatement, which can include obtaining a limited or provisional license, enrolling in therapeutic or educational programs, taking a relicensing examination, paying various fees, and others.

Due process requires a review procedure for appealing the revocation. A hearing by an administrative official must be requested within a given time period. The hearing may concern issues such as whether the police officer had sufficient reason to stop the driver and whether the stop yielded sufficient reason (e.g., "probable cause") for arrest. The hearing officer's decision is based on the administrative standard of preponderance of evidence, rather than the criminal standard of proof beyond a reasonable doubt. If requested, the hearing must be held within a specified time. The revocation action is usually stayed pending the results of the review.

Most states impose the loss of driving privileges if no hearing is held or if this administrative hearing finds against the driver. The license may either be suspended (driving privileges return automatically at the end of the license-suspension period) or revoked (the license is lost and the offender must obtain a new license at the end of the period of restriction). Suspended drivers are typically more easily reintegrated into the licensing system once the sanction period is over.

Table 1-1 demonstrates the variety of versions of ALR currently adopted in the 50 states and DC (as of January 1996) by listing the following information for each state as well as for the model statute offered by the Uniform Vehicle Code, which generally parallels the model Revocation on Administrative Determination (ROAD) Act offered by NHTSA.

1. BAC defined as illegal per se;

2. Existence of ALR laws in the state (yes/no); indication of whether the license is suspended (S) or revoked (R) for states with ALR; and effective date of ALR law;

3. Term of temporary license issued by police officer when permanent license taken;

4. For administrative per se hearings, time offender has to request a hearing and time within which the hearing must be held if requested;

5. Term of license suspension/revocation for first offense for positive test results; and 
6. Availability of a hardship license (which permits commuting to and from work for first offenders who meet certain criteria) and length of mandatory (hard) suspension.

Although the ALR laws shown in Table 1-1 vary widely by state, the states can be characterized as falling into one of the following four categories:

1. No Laws. The driver's license can only be suspended after a criminal conviction.

2. ALR/Immediate Hardship License. A hardship license (e.g., for employment) can be obtained for the duration of the suspension period, with no mandatory "hard" suspension period.

3. ALR/30-60 Day Mandatory Suspension. The license suspension period is typically 90 days, but a hardship license can be obtained after a full or "hard" suspension period of 30-60 days. However, there is a short period after the DUI arrest when the DUI offender has a temporary license so that transportation arrangements can be made.

4. ALR/90+ Day Mandatory Suspension. A "hard" suspension period of at least 90 days is prescribed.

The above categorization of each state (as of January 1996) is shown on the map in Figure 1-1.

\subsection{The Benefits of Administrative License Revocation}

This study accepts from the existing literature the proposition that ALR is an effective penalty. Although as with all social policy, it is only partially effective, and the literature vouches for the fact that it accomplishes important improvements in safety at reasonable direct cost. The accomplishments of ALR include: incapacitation of the dangerous drivers represented by the offenders; their reform through mandated treatment and education programs; and deterrence of others, who see the consequences of apprehension for DUI increased in certainty and swiftness with ALR.

Substantial research testifies to the fact that revoked offenders experience reduced crashes and violations. Although the accumulation of any such incidents would be impossible if license revocation were completely effective, the reduction represents an important safety benefit. It appears that individuals driving in violation of revocation orders fear the consequences of apprehension, leading them to reduce their driving and to improve its safety. Furthermore, the improved safety can be perceived beyond the duration of the license revocation. This may perhaps be explained in terms of successful education and therapy, or it may reflect offenders' failure to obtain new 
Table 1-1. Status of Administrative License Revocation by State (Source: IIHS, 1995)

\begin{tabular}{|c|c|c|c|c|c|c|c|c|}
\hline \multirow[b]{2}{*}{ State } & \multirow[b]{2}{*}{$\begin{array}{c}\text { BAC } \\
\text { Defined } \\
\text { as Illegal } \\
\text { Per Se }\end{array}$} & \multirow[b]{2}{*}{$\begin{array}{c}\text { Existence of } \\
\text { Administrative } \\
\text { License } \\
\text { Suspension(S)/ } \\
\text { Revocation(R) } \\
\text { (Effective Date) }\end{array}$} & \multirow[b]{2}{*}{$\begin{array}{l}\text { Term of } \\
\text { Temporary } \\
\text { License }\end{array}$} & \multicolumn{2}{|c|}{ Administrative Per Se Hearing } & \multirow[b]{2}{*}{$\begin{array}{c}\text { Term of } \\
\text { License } \\
\text { Suspension } \\
\text { for Positive } \\
\text { Test Results }\end{array}$} & \multirow[b]{2}{*}{$\begin{array}{l}\text { Hardship } \\
\text { License } \\
\text { Availability for } \\
\text { 1st Offense }\end{array}$} & \multirow[b]{2}{*}{$\begin{array}{l}\text { Length of } \\
\text { Mandatory (Hard) } \\
\text { Suspension }\end{array}$} \\
\hline & & & & Request Within & $\begin{array}{l}\text { Hold } \\
\text { Within }\end{array}$ & & & \\
\hline Vifiform & Percent & yesin & 7110115 days & 711019 days & 20 days & 00 days & 30 days & 30 days \\
\hline Alabama & $\begin{array}{c}0.08 \\
\text { Percent }\end{array}$ & no & - & - & - & - & - & - \\
\hline Alaska & $0 \%$ Percent & yes/ $(1017183)$ & 7 days & 7 days & +2 & 900ays & $300 \mathrm{ays}$ & 300 ays \\
\hline Arizona & $\begin{array}{c}0.10 \\
\text { Percent }\end{array}$ & yes/S (1/1/88) & 15 days & 15 days & - & 90 days & 30 days & 30 days \\
\hline Aransas & peroent & no (neWALPloW & \% & 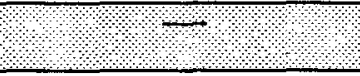 & Ð & •ै। & ?. & ?. \\
\hline California & $\begin{array}{c}0.08 \\
\text { Percent }\end{array}$ & yes/S $(7 / 1 / 90)$ & 45 days & 45 days & 45 days & 4 months & 30 days & 30 days \\
\hline Colorado & 010 Percent & Vesin $(11983)$ & odays & 7 days & $6000 y$ & 3 months & No hardship & 3 months \\
\hline Connecticut & $\begin{array}{c}0.10 \\
\text { Percent }\end{array}$ & yes/S $(1 / 1 / 90)$ & 35 days & 7 days & 35 days & 90 days & $\begin{array}{l}\text { Immediate } \\
\text { availability }\end{array}$ & $\begin{array}{c}\text { No mandatory } \\
\text { suspension }\end{array}$ \\
\hline Delaware & 010 & yesik $(2 / 8 / 83)$ & 15 obys & 15 days & so days to & 3 months & No hardship & 3 months \\
\hline $\begin{array}{l}\text { District of } \\
\text { Columbia }\end{array}$ & $\begin{array}{c}0.10 \\
\text { Percent }\end{array}$ & yes/s (1955) & 5 days & 5 days & - & $\begin{array}{l}\text { 2-30 days (at } \\
\text { discretion of } \\
\text { director) }\end{array}$ & $\begin{array}{l}\text { Immediate } \\
\text { availability }\end{array}$ & $\begin{array}{l}\text { No mandatory } \\
\text { suspension }\end{array}$ \\
\hline Florida & 0.08 Percent & yesis $(10 / 190)$ & 10ays & 10 days & 30 odys & 6 months & 30 obys & 30 days \\
\hline Georgia & $\begin{array}{c}0.10 \\
\text { Percent }\end{array}$ & yes/S (7/1/94) & 30 days & 10 days & 30 days & 1 year & $\begin{array}{l}\text { Immediate } \\
\text { availability }\end{array}$ & $\begin{array}{c}\text { No mandatory } \\
\text { suspension }\end{array}$ \\
\hline Hawail & Percent? & yesiR & 30 days & 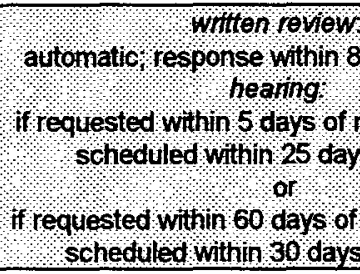 & $\begin{array}{l}\text { sor arrest } \\
\text { arest } \\
\text { st nust } \\
\text { equest }\end{array}$ & 3 months & 30 oays & 300 ays \\
\hline Idaho & $\begin{array}{c}0.10 \\
\text { Percent }\end{array}$ & yes/s $(7 / 1 / 94)$ & 30 days & 7 days & 20 days & 90 days & 30 days & 30 days \\
\hline Ilinois & $010 \%$ & yesis (11186) & 45 days & anytime diung suspension & 30 days & 3 months & Immediate & $\begin{array}{l}\text { No mandatory } \\
\text { suspension }\end{array}$ \\
\hline
\end{tabular}


Table 1-1. Status of Administrative License Revocation by State (Source: IIHS, 1995)

\begin{tabular}{|c|c|c|c|c|c|c|c|c|}
\hline \multirow[b]{2}{*}{ State } & \multirow[b]{2}{*}{$\begin{array}{c}\text { BAC } \\
\text { Defined } \\
\text { as Illegal } \\
\text { Per Se }\end{array}$} & \multirow[b]{2}{*}{$\begin{array}{c}\text { Existence of } \\
\text { Administrative } \\
\text { License } \\
\text { Suspension(S)/ } \\
\text { Revocation(R) } \\
\text { (Effective Date) }\end{array}$} & \multirow[b]{2}{*}{$\begin{array}{l}\text { Term of } \\
\text { Temporairy } \\
\text { License }\end{array}$} & \multicolumn{2}{|c|}{ Administrative Per Se Hearing } & \multirow[b]{2}{*}{$\begin{array}{c}\text { Term of } \\
\text { License } \\
\text { Suspension } \\
\text { for Positive } \\
\text { Test Results }\end{array}$} & \multirow[b]{2}{*}{$\begin{array}{c}\text { Hardship } \\
\text { License } \\
\text { Availability for } \\
\text { 1st Offense }\end{array}$} & \multirow[b]{2}{*}{$\begin{array}{l}\text { Length of } \\
\text { Mandatory (Hard) } \\
\text { Suspension }\end{array}$} \\
\hline & & & & Request Within & $\begin{array}{l}\text { Hold } \\
\text { Within }\end{array}$ & & & \\
\hline Indiana & $\begin{array}{c}0.10 \\
\text { Percent }\end{array}$ & yes/S (9/1/83) & $\begin{array}{l}\text { valid until } \\
\text { hearing }\end{array}$ & N/A (hearing automatic) & 20 days & 180 days & 30 days & 30 days \\
\hline 10wa & peroent & $y e s / R(71182)$ & 20 days & 300 ays & 45 days & 180 days & 30 days & 300 ays \\
\hline Kansas & $\begin{array}{c}0.08 \\
\text { Percent }\end{array}$ & yes/S $(7 / 1 / 88)$ & 20 days & 10 days & 30 days & 30 days & $\begin{array}{l}\text { No hardship } \\
\text { license }\end{array}$ & 30 days \\
\hline Kentucky & Percent & no & ২ैै & ڤै & m & ?. & ?ै & 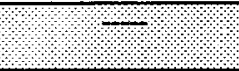 \\
\hline Louisiana & $\begin{array}{c}0.10 \\
\text { Percent }\end{array}$ & yes/S $(9 / 3 / 84)$ & 30 days & 10 days & - & 90 days & 30 days & 30 days \\
\hline Malne & Percent & yests $(1 / 184)$ & nonet taken & 10 days & 30 days & 90 days & availability & No mandaton \\
\hline Maryland & $\begin{array}{c}0.10 \\
\text { Percent } \\
(10 / 1 / 95)\end{array}$ & yes/S $(1 / 1 / 90)$ & 45 days & 30 days & 45 days & 45 days & $\begin{array}{l}\text { Immediate } \\
\text { availability }\end{array}$ & $\begin{array}{l}\text { No mandatory } \\
\text { suspension }\end{array}$ \\
\hline Massachusetts & 008 & yes/s $(6 / 27 / 94)$ & no temporary & immediate & (10modate & oodays & No hardship & 90 days \\
\hline Michigan & $\begin{array}{c}0.10 \\
\text { Percent }\end{array}$ & no & - & - & - & - & - & - \\
\hline Minnesola & 010 & yes/R $(9 / 1 / 78)$ & 7 days & 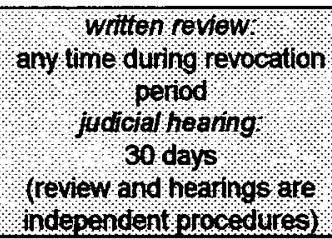 & $\begin{array}{l}15 \text { days } \\
60 \text { days }\end{array}$ & 90 days & 15 days & 15 days \\
\hline Mississippi & $\begin{array}{c}0.10 \\
\text { Percent }\end{array}$ & yes/S $(7 / 1 / 83)$ & 30 days & 30 days & 30 days & 90 days & 30 days & 30 days \\
\hline Nissoun & 0.0 & yesth $(9 / 28 / 83)$ & 15 days & 15 days & 30 days & 90 days & 30 days & 30 days \\
\hline Montana & $\begin{array}{c}0.10 \\
\text { Percent }\end{array}$ & no & - & - & - & - & - & - \\
\hline Nebroska & Peroen & yes/R $(1 / 1 / 93)$ & 30 days & 10 days & 20 days & 9006,4 & 30 days & 30 days \\
\hline Nevada & $\begin{array}{c}0.10 \\
\text { Percent }\end{array}$ & yes/R $(7 / 1 / 83)$ & 7 days & $\begin{array}{l}\text { any time during revocation } \\
\text { period }\end{array}$ & 15 days & 90 days & 45 days & 45 days \\
\hline
\end{tabular}


Table 1-1. Status of Administrative License Revocation by State (Source: IIHS, 1995)

\begin{tabular}{|c|c|c|c|c|c|c|c|c|}
\hline \multirow[b]{2}{*}{ State } & \multirow[b]{2}{*}{$\begin{array}{c}\text { BAC } \\
\text { Defined } \\
\text { as Illegal } \\
\text { Per Se }\end{array}$} & \multirow[b]{2}{*}{$\begin{array}{c}\text { Existence of } \\
\text { Administrative } \\
\text { License } \\
\text { Suspension(S)/ } \\
\text { Revocation(R) } \\
\text { (Effective Date) }\end{array}$} & \multirow[b]{2}{*}{$\begin{array}{l}\text { Term of } \\
\text { Temporary } \\
\text { License }\end{array}$} & \multicolumn{2}{|c|}{ Administrative Per Se Hearing } & \multirow[b]{2}{*}{$\begin{array}{l}\text { Term of } \\
\text { License } \\
\text { Suspension } \\
\text { for Positive } \\
\text { Test Results }\end{array}$} & \multirow[b]{2}{*}{$\begin{array}{l}\text { Hardship } \\
\text { License } \\
\text { Availability for } \\
\text { 1st Offense }\end{array}$} & \multirow[b]{2}{*}{$\begin{array}{l}\text { Length of } \\
\text { Mandatory (Hard) } \\
\text { Suspension }\end{array}$} \\
\hline & & & & Request Within & $\begin{array}{l}\text { Hold } \\
\text { Within }\end{array}$ & & & \\
\hline New & $\begin{array}{r}0.08 \\
\text { Percent }\end{array}$ & yesis $(713 / 92)$ & $30 \mathrm{day}$ & 30 days & 20 days & 6 months & No hardship & 6 nonths \\
\hline New Jersey & $\begin{array}{c}0.10 \\
\text { Percent }\end{array}$ & no & - & - & $\ldots$ & - & - & - \\
\hline New Mexico & percent & yes/R $(1 / 184)$ & 20 days & 10days & 00 days & 90 days & 30 oays & 30 days \\
\hline New York & $\begin{array}{c}0.10 \\
\text { Percent }\end{array}$ & no & $\cdots$ & - & - & - & - & - \\
\hline North Carolina & 0.08 Percent & yes/R $(101 / 83)$ & notemporay & \multicolumn{2}{|c|}{ 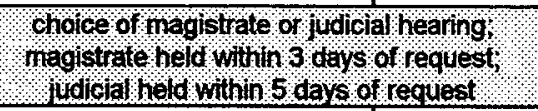 } & 10 days & $\begin{array}{l}\text { No hardship } \\
\text { icense }\end{array}$ & 10 days \\
\hline North Dakota & $\begin{array}{c}0.10 \\
\text { Percent }\end{array}$ & yes/S (7/1/83) & 25 days & 10 days & 25 days & 91 days & 30 days & 30 days \\
\hline ohio & 010 & yests $(71993)$ & 15 days & 15 days & 30 days & 90 days & 15 days? & 15 days \\
\hline Oklahoma & $\begin{array}{c}0.10 \\
\text { Percent }\end{array}$ & yes/R $(4 / 1 / 83)$ & 30 days & 15 days & - & 180 days & $\begin{array}{l}\text { Immediate } \\
\text { availability }\end{array}$ & $\begin{array}{l}\text { No mandatory } \\
\text { suspension }\end{array}$ \\
\hline oregon & Peroent & yes/s $(71184)$ & 30 days & 10 days & 30 days & 90 ovys & 30 days & 30 days \\
\hline Pennsytvania & $\begin{array}{c}0.10 \\
\text { Percent }\end{array}$ & no & - & - & - & - & - & - \\
\hline Rhodelsland & $\begin{array}{l}010 \\
\text { Peroent }\end{array}$ & no & 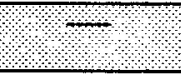 & 0 & 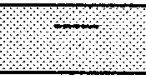 & ? & $\checkmark$ & \% \\
\hline South Carolina & none' & no & - & - & - & - & - & - \\
\hline South Bakota & Percent & no & 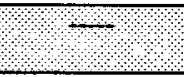 & 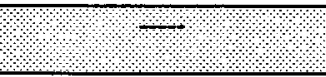 & ? & ? & \% & ॠै \\
\hline Tennessee & $\begin{array}{c}0.10 \\
\text { Percent }\end{array}$ & no & - & - & - & - & - & - \\
\hline texas & Percent & yes/s 11105$)$ & no teroporary & 150ays & 11 days & 60 days & $\begin{array}{l}\text { Inmediate } \\
\text { availability }\end{array}$ & No nandatory \\
\hline Utah & $\begin{array}{c}0.08 \\
\text { Percent }\end{array}$ & yes/S $(8 / 1 / 83)$ & 29 days & 10 days & 30 days & 90 days & $\begin{array}{l}\text { No hardship } \\
\text { license }\end{array}$ & 90 days \\
\hline Vemont & Percent & yes/s $(121189)$ & $\begin{array}{l}\text { license not } \\
\text { taken }\end{array}$ & 7 days & 30 days & 90 days & No hardship & 90 days \\
\hline Virginia & $\begin{array}{c}0.08 \\
\text { Percent }\end{array}$ & yes/S (1/1/95) & $\begin{array}{l}\text { no temporary } \\
\text { license }\end{array}$ & immediate (in lieu of bail) & $\begin{array}{l}\text { immediate } \\
\text { (in lieu of } \\
\text { bail) }\end{array}$ & 7 days & $\begin{array}{l}\text { No hardship } \\
\text { license }\end{array}$ & 7 days \\
\hline
\end{tabular}


Table 1-1. Status of Administrative License Revocation by State (Source: IIHS, 1995)

\begin{tabular}{|c|c|c|c|c|c|c|c|c|}
\hline \multirow[b]{2}{*}{ State } & \multirow[b]{2}{*}{$\begin{array}{c}\text { BAC } \\
\text { Defined } \\
\text { as Illegal } \\
\text { Per Se }\end{array}$} & \multirow[b]{2}{*}{$\begin{array}{c}\text { Existence of } \\
\text { Administrative } \\
\text { License } \\
\text { Suspension(S)/ } \\
\text { Revocation(R) } \\
\text { (Effective Date) }\end{array}$} & \multirow[b]{2}{*}{$\begin{array}{l}\text { Term of } \\
\text { Temporary } \\
\text { License }\end{array}$} & \multicolumn{2}{|c|}{ Administrative Per Se Hearing } & \multirow[b]{2}{*}{$\begin{array}{c}\text { Term of } \\
\text { License } \\
\text { Suspension } \\
\text { for Positive } \\
\text { Test Results }\end{array}$} & \multirow[b]{2}{*}{$\begin{array}{l}\text { Mardship } \\
\text { License } \\
\text { Availability for } \\
\text { 1st Offense }\end{array}$} & \multirow[b]{2}{*}{$\begin{array}{l}\text { Length of } \\
\text { Mandatory (Hard) } \\
\text { Suspension }\end{array}$} \\
\hline & & & & Request Within & $\begin{array}{l}\text { Hold } \\
\text { Within }\end{array}$ & & & \\
\hline Washington & Percent & 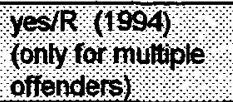 & $\begin{array}{l}\text { marked } \\
\text { lcenselor } 60\end{array}$ & 30 days & $\begin{array}{l}600 \text { orys } \\
\text { ronolices }\end{array}$ & \multicolumn{2}{|c|}{ Probationaly license for 5 years for } & so mandatory \\
\hline West Virginia & $\begin{array}{l}0.10 \\
\text { Percent }\end{array}$ & yes/R $(9 / 1 / 81)$ & $\begin{array}{l}\text { prescribed by } \\
\text { DMV ( } 30 \\
\text { days) }\end{array}$ & 10 days & 20 days & 6 months & 30 days $^{2}$ & 30 days \\
\hline Wisconsin & percent & yesiR $(1 / 1888)$ & $30 \mathrm{days}$ & 10 orys & 30 obys & 6 montlis & lonediate & No mandalon \\
\hline Wyoming & $\begin{array}{c}0.10 \\
\text { Percent }\end{array}$ & yes/S $(7 / 1 / 85)$ & 30 days & 20 days & 45 days & 90 days & $\begin{array}{l}\text { Immediate } \\
\text { availability }\end{array}$ & $\begin{array}{l}\text { No mandatory } \\
\text { suspension }\end{array}$ \\
\hline
\end{tabular}

${ }^{1}$ DUI/DWI laws are not per se laws. A BAC of 0.10 percent is evidence of alcohol impairment but is not illegal per se.

2 With participation in ignition interlock program. 


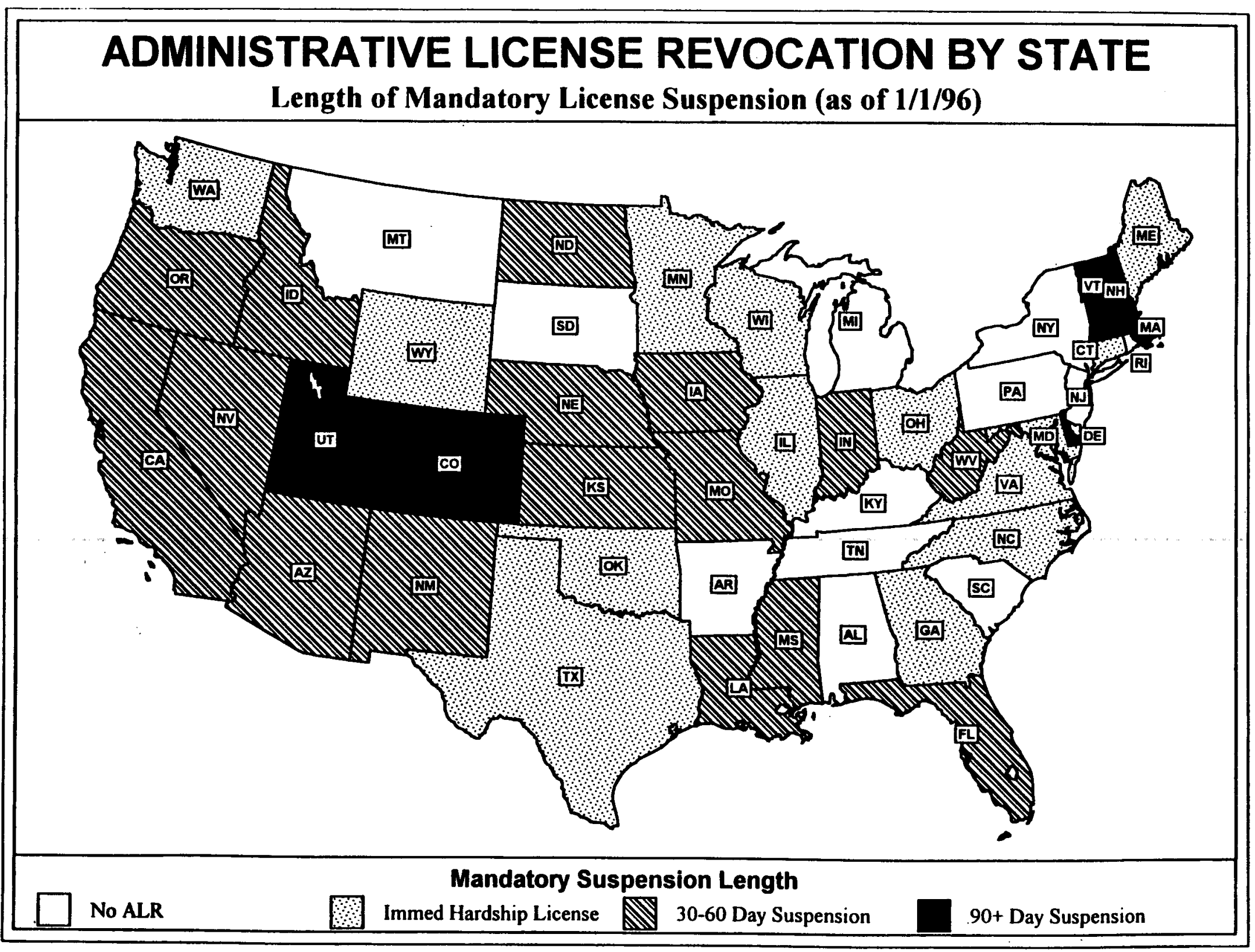

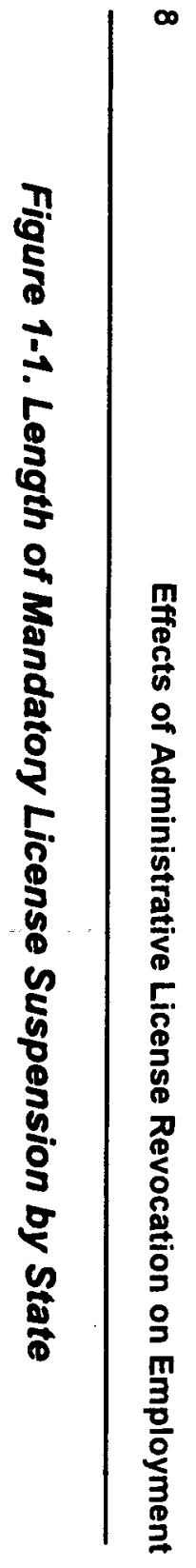


licenses and thus a continuation of the reduced mileage and greater prudence noted during the revocation. Thus, although compliance with license revocation is only partial, it produces important safety benefits by modifying the behavior of DUI offenders.

Moreover, there are benefits in terms of increased safety in the driving of persons other than the known offenders. ALR is associated with decreased rates of alcohol-involved crashes sufficiently large that they cannot be explained in terms of changes in the violators alone. The decrease is understood in terms of general deterrence, a response to the perceived swiftness and certainty (as well as severity) of the deterrent threat.

But all policies have costs, which have to be weighed against their benefits. The state attempts to pass on the direct financial costs of DUI measures to the violators as part of the remedial action, but a social cost is incurred regardless of who pays, and it must be reckoned with. As noted previously, ALR appears to be a relatively cheap policy from the viewpoint of direct costs. However, one of the reasons offered for not adopting this proved safety measure is the indirect cost of taking an offender's license in the form of potential loss of income or employment. Although this cost impinges most directly on the offender, indirectly it involves his (presumably innocent) dependents, and possibly the public treasury to the extent that the violator's reduction in income impoverishes the dependents. If we take the license, it is claimed, we take the job and we end up paying the offender's salary from the public treasury.

This is not a trivial objection. If income and employment losses are common, the benefits of ALR must be demonstrably greater in order to justify the system. If the balance is in question, various policy options other than repealing ALR may be considered. For example, if job loss is related to the length of revocation, the mandatory period could be made short enough to avoid job consequences but long enough to be perceived as punitive. Another possible modification is to allow hardship licenses permitting driving on work-related trips on certain roads at certain times. Other possibilities such as mandating installation of breath-alcohol interlocks in the vehicles driven by the offender also come to mind. The aim of this research was to explore the employment and income consequences of ALR under laws differing in the length of revocation and in the availability of hardship licenses.

\subsection{The Prior Literature}

There has been considerable prior work concerning this topic, although limited to case studies and briefly reported. Known studies concerning the employment and income effects of license revocation include: one in Mississippi (Wells-Parker and Cosby, 1987); one in New Mexico and Arizona (Ross and Gonzales, 1988); one in California (Peck, Sadler and Perrine, 1986); one in Delaware (Johnson, 1986); and one in Australia (Robinson, n.d.) 
This prior literature has found that income and employment losses are experienced by only a small minority of persons losing their licenses as a consequence of DUI. (This is true despite the fact that dependence on the private car is quite extensive, especially for those workers like traveling salespeople or construction workers, who perform their work at disparate locations and who need to haul tools and supplies.) The fact begs for an explanation. Among the reasons that can be cited are: (1) some important fraction of workers do not commute, but earn their income by working at home or walking to work; (2) some are able to substitute alternative means of getting to work, such as car pooling or using public transportation; and (3) some evade the remedial action by driving without licenses. The current study investigated the extent to which these alternatives are realized.

\subsection{Project Objectives}

Despite the evidence in favor of administrative license revocation for DUI offenders, as of January 1996, there are still 12 states that do not have ALR laws. One reason that has been given for the reluctance of legislators to impose license suspension/revocation is that the denial of driving privileges is seen as producing severe economic hardship (namely the inability of the DUI offender to go to work) for the offenders and their families. Although the research in Delaware, New Mexico, Arizona, and Mississippi indicates that the effect of ALR on employment is minimal, the research is thin in this area. In the absence of quantitative data regarding the actual effects of ALR on employment, it is impossible to know whether the perceived draconian effect on employment actually occurs for an important fraction of DUI offenders.

Therefore, in order to examine the actual effect of ALR on the employment of DUI offenders and the victims of crashes associated with these offenders, NHTSA funded the current research project. The results of the research provide NHTSA with information to present to states that are considering enacting ALR laws.

The three main objectives of this research project were to:

1. Determine the impact of short-term (30-45 days) administrative license suspension/revocation on the employment and income of first offenders.

2. Determine the impact of longer-term ( 6 months to a year) administrative license suspension/revocation on the employment and income of multiple offenders.

3. Determine the effects of alcohol-related crashes and injuries on the employment of other crash-involved persons (i.e., innocent drivers, passengers, and pedestrians). 


\subsection{RESEARCH APPROACH AND METHODOLOGY}

The study was designed to investigate the consequences of license revocation by choosing jurisdictions representing four legal categories. In one jurisdiction, Delaware, administrative license revocation for 90 days is automatic for persons arrested for DUI and failing the mandated breath test. In a second, California, although a suspension period of 120 days is prescribed, hardship licenses are available after 30 days. In the third, Maryland, a DUI offender has a formal suspension period of 45 days, but can receive a hardship license without any period of "hard" suspension. The fourth case, Pennsylvania, represents non-ALR jurisdictions. In Pennsylvania, there are no mandated consequences for failing a breath test at the scene of an arrest; it is not until a suspect is convicted that the possibility of license revocation arises. These four cases represent the range of license revocation provisions generally used for DUI.

In order to appreciate any impacts that may be found, the study was designed to compare employment and income effects of license revocation on DUI offenders with the employment and income effects of injury-producing DUI crashes on victims, pedestrians, non-impaired drivers, and their passengers.

\subsection{Sampling and Instruments}

A problem with comparing different jurisdictions is that the law is not the only thing that differentiates them. One can expect differences in climate, demography, the economy and, most generally, culture. A problem arises in interpreting whether differences found between the jurisdictions are caused by the variable according to which they were selected.

The approach used to control for these factors was to select jurisdictions with different laws but similar socio-demographics and proximate locations. Three of the states were contiguous: Pennsylvania (without ALR), Maryland (with immediate hardship licenses), and Delaware (with 90 days "hard" suspension). From each of these states, one county was selected on the basis of physical and social similarity to the others. The counties were Chester, Anne Arundel, and New Castle, respectively.

These jurisdictions did not provide an example of a state making hardship licenses available after 30 days. Indeed, there are none contiguous to the three mentioned above. Because of its excellent statistical system and cooperative officials, California was selected as a comparison state. It lacks contiguity, but Marin County is socio-demographically similar to the other sample counties. Table 2-1 presents selected demographic data for the study counties. 
Table 2-1. Demographics for Four Study Sites (1990 Census Data)

\begin{tabular}{|c|c|c|c|c|}
\hline & Chester Co, PA & $\begin{array}{c}\text { Anne Arundel } \\
\text { Co., MD }\end{array}$ & Marin co. $\mathrm{CA}$ & $\begin{array}{c}\text { New Castle Co., } \\
\text { DE }\end{array}$ \\
\hline Population & 376396 & 427,239 & 230096 & 441,946 \\
\hline White & $344 / 931(92 \%)$ & $365,953(86 \%)$ & $204.128(89 \%)$ & $355,399(80 \%)$ \\
\hline Black & $239956 \%$ & $50,525(12 \%)$ & $8.172(6 \%)$ & $72,834(16 \%)$ \\
\hline $\begin{array}{l}\text { American } \\
\text { Indian }\end{array}$ & $510(0.1 \%)$ & $1,292(0.3 \%)$ & $789(03 \%)$ & $760(0.2 \%)$ \\
\hline Asian & $4.070(1 \%)$ & $7,675(2 \%)$ & $9,442(4 \%)$ & $7,048(2 \%)$ \\
\hline $\begin{array}{l}\text { Hispanic (any } \\
\text { race) }\end{array}$ & $8,565(2 \%)$ & $6,815(2 \%)$ & $17930(8 \%)$ & $11,804(3 \%)$ \\
\hline \multicolumn{5}{|l|}{ Age \% } \\
\hline$\leq 17$ & $249 \%$ & $24.6 \%$ & $19.1 \%$ & $24 \%$ \\
\hline $18-24$ & $10 \%$ & $10.9 \%$ & $76 \%$ & $12.1 \%$ \\
\hline $25-44$ & $34 \%$ & $35.5 \%$ & $378 \%$ & $33.7 \%$ \\
\hline $45-64$ & $20.1 \%$ & $20.1 \%$ & $233 \%$ & $18.9 \%$ \\
\hline $65+$ & $10.9 \%$ & $8.8 \%$ & $12.3 \%$ & $11.4 \%$ \\
\hline $\begin{array}{l}\text { Males per } 100 \\
\text { Females }\end{array}$ & 96.1 & 101.4 & 982 & 93.8 \\
\hline Persons/Household & 273 & 2.76 & 233 & 2.61 \\
\hline \multicolumn{5}{|l|}{ Education } \\
\hline $\begin{array}{l}\text { \% High school } \\
\text { grad or higher }\end{array}$ & $849 \%$ & $81.1 \%$ & $91 \% \%$ & $80.6 \%$ \\
\hline $\begin{array}{l}\% \text { Bachelors } \\
\text { degree } \\
\text { or higher }\end{array}$ & $34.7 \%$ & $24.6 \%$ & $440 \%$ & $25.2 \%$ \\
\hline $\begin{array}{l}\text { Median annual } \\
\text { family income }\end{array}$ & $\$ 52325$ & $\$ 49,706$ & $\$ 59157$ & $\$ 45,216$ \\
\hline $\begin{array}{l}\text { Average \# } \\
\text { vehicles/household }\end{array}$ & 199 & 2.0 & 180 & $\overline{1.7}$ \\
\hline $\begin{array}{l}\text { Average commute } \\
\text { time (min. to work) }\end{array}$ & $239 \mathrm{~min}$ & $25.9 \mathrm{~min}$ & $28 . \mathrm{min}$ & $20.3 \mathrm{~min}$ \\
\hline $\begin{array}{l}\text { Unemployment rate } \\
(\%)\end{array}$ & $46 \%$ & $5.0 \%$ & $40 \%$ & $6.2 \%$ \\
\hline \multicolumn{5}{|l|}{$\begin{array}{l}\text { Employment by } \\
\text { industry }\end{array}$} \\
\hline $\begin{array}{l}\text { \% Agriculture, } \\
\text { forestry, fishing }\end{array}$ & $36 \%$ & $1.1 \%$ & $10 \%$ & $1.1 \%$ \\
\hline$\%$ Manufacturing & $197 \%$ & $10.5 \%$ & $76 \%$ & $19.6 \%$ \\
\hline $\begin{array}{l}\text { \% Wholesale/ } \\
\text { retail trade }\end{array}$ & $20.1 \%$ & $21.9 \%$ & $19.3 \%$ & $18.6 \%$ \\
\hline $\begin{array}{l}\text { \% Finance, } \\
\text { insurance, real } \\
\text { estate }\end{array}$ & $8.5 \%$ & $6.5 \%$ & $129 \%$ & $11.7 \%$ \\
\hline $\begin{array}{l}\text { \% Health } \\
\text { services }\end{array}$ & $84 \%$ & $5.9 \%$ & $92 \%$ & $8.0 \%$ \\
\hline $\begin{array}{l}\text { \% Public } \\
\text { administration }\end{array}$ & $1.8 \%$ & $13.8 \%$ & $36 \%$ & $3.3 \%$ \\
\hline
\end{tabular}

* Source: US Bureau of the Census, County and City Data Book: 1994, Washington, DC 
Prior experience with similar research suggested that random sampling from state records of the DUI population would not succeed in reaching DUI offenders. Therefore, the methodology used in Ross and Gonzales (1988) of requesting subjects from DUI treatment and education programs was followed. Both in the past and for this project, administering questionnaires in these programs resulted in excellent cooperation. The quid pro quo that was offered was a discussion of the expectations and previous findings concerning the research topic.

The population of DUI arrestees is further not statistically representative of persons who drink and drive illegally. The arrest rate for DUI is estimated at a range of from one in 500 to one in 2,000 occasions, and very dangerous drivers may take the road for many years without encountering police. The size of the community, the staffing of police departments, and the priority given to DUI patrol are some of the variables that affect this probability. Furthermore, police may systematically release greater proportions of some kinds of offenders whom they meet-for instance, middle-class, respectable, well-mannered persons. Women may possibly find greater leniency in some interactions with law enforcement than men. Other circumstances such as time of day, type of road, and type of vehicle driven may affect police suspiciousness and thus the likelihood of an arrest for DUI.

To the extent that these mandated programs represent DUls, the method is successful in obtaining representative or complete population samples. Of course, some proportion of those convicted do not participate in the mandated programs, either leaving the area or simply accepting that an arrest warrant may be issued. Such persons probably cannot be reached by any systematic method, and are likely to have a low cooperation rate if actually found.

It was concluded that this method of locating subjects would suffice for the present study. In each of the counties, all programs providing services to DUI offenders were located and requested to cooperate in allowing their classes/treatment groups to complete a paper-and-pencil questionnaire.

A questionnaire guided by these expectations was designed for classroom administration. There were five successive versions, as pretesting in New Mexico and Pennsylvania indicated what was necessary for clear communication. Furthermore, once it was discovered that both California and Pennsylvania institutions offered classes for Spanish-speaking people, the questionnaire was translated into Spanish for use with these special classes and anyone else who indicated a preference. (Unfortunately, the Hispanic sample, largely Mexican immigrants, frequently proved to be illiterate in Spanish as well as English, and it was not possible to complete a planned analysis of them.) Appendix A contains the questionnaire administered in the three ALR states. (The Pennsylvania questionnaire deleted questions that addressed ALR.) Appendix B contains the Spanish version of the ALR questionnaire. 


\subsection{The Victim Survey}

A comparison group of "victims" was selected, defined as people other than the impaired drivers involved in alcohol-related injury crashes in the same counties. These were largely unimpaired drivers of other cars, along with some passengers and pedestrians.

Victims thus defined are a difficult group to find and study. In California and Delaware, state records were used to identify qualifying crashes in the respective counties, from about the time that the DUI offenders were apprehended. For reasons of confidentiality, state officials hired clerks to identify appropriate persons, and send them questionnaires based on items from the DUI instrument, with the request to return these by mail to the contractor. Stamped return envelopes were provided for this purpose. It was assumed that victims had a story they would want to tell and that endorsement by the state would produce high response rates, but a surprisingly low response rate was obtained--32 percent of 189 individuals in Delaware and 19 percent of 192 in California. A victim population could not be identified in Maryland.

In Pennsylvania, the state proved unable to provide appropriate files, so DUI arrest records from the District Attorney's Office in Chester County were scanned to locate those that involved crashes. The crash reports were then read to extract the names and addresses of third parties ("victims") involved in these crashes, to whom questionnaires were sent.

Since it was not expected that important differences would be found among victims related to the ALR laws, the analysis was performed largely on the basis of the combined samples from all states. Table 2-2 presents summary Victim Survey information for the three states in which surveys were distributed. It is important to note that alcohol-related crash victims represent a small percent of all persons injured in alcohol-involved crashes. Appendix $\mathrm{C}$ contains the Victim Survey and the letters of cooperation that were enclosed by the agency noted in Table 2-2 for California, Delaware, and Pennsylvania.

\subsection{DUI Offender Survey Administration}

After the four representative counties were selected as described above, letters were sent to the NHTSA Regional Offices in Region III (PA, DE, and MD) and Region IX (CA), explaining the project and soliciting their cooperation. Next, State Governor's Highway Safety/DUI Representatives in each of the four states were contacted by mail to explain the project and also solicit their cooperation.

Once all clearances were obtained at the state level, the organizations that run the first-offender DUI schools and repeat-offender DUI treatment programs in each of the four selected counties were contacted by telephone. They were asked whether they would be willing to incorporate the distribution and completion of DUI Offender Surveys into their 
Table 2-2. DUI Crash Victim Survey Information

\begin{tabular}{|c|c|c|c|}
\hline \multirow{2}{*}{$\begin{array}{l}\text { Agency Assisting in } \\
\text { Survey Distribution }\end{array}$} & Oaliforna & Delaware & Pennsylvania \\
\hline & $\begin{array}{l}\text { Department of Motor } \\
\text { Yehicles } \\
\text { Sacramento }: \text { A }\end{array}$ & $\begin{array}{l}\text { Delaware State Police } \\
\text { Dover, DE }\end{array}$ & $\begin{array}{l}\text { Chester County Bistrict. } \\
\text { Attorney s office } \\
\text { West Chester, PA }\end{array}$ \\
\hline $\begin{array}{l}\text { Time frame for crash } \\
\text { selection }\end{array}$ & $5 / 934 / 94$ & 4/93-3/94 & 493.4194 \\
\hline County of crash & Marin and Sonoma & New Castle County, DE & Chester County. PA. \\
\hline Victim selection criteria & $\begin{array}{l}\text { l6 years old } \mathrm{CA} \text {. } \\
\text { resident non fatal } \\
\text { injury, not driving under } \\
\text { influence? }\end{array}$ & $\begin{array}{l}216 \text { years old, non-fatal } \\
\text { injury, not "driving under } \\
\text { influence" }\end{array}$ & $\begin{array}{l}\text { I6 years old non-fatal } \\
\text { injury, victim" on crash? } \\
\text { investigation torm }\end{array}$ \\
\hline $\begin{array}{l}\text { Total surveys mailed } \\
\text { (date) }\end{array}$ & $200(2 / 14 / 95)$ & $201(2 / 20 / 95)$ & $197(4 / 20 / 95)$ \\
\hline $\begin{array}{l}\text { Number surveys } \\
\text { returned undeliverable }\end{array}$ & 8 & 12 & 15 \\
\hline $\begin{array}{l}\text { Number surveys that } \\
\text { presumably reached } \\
\text { victims }\end{array}$ & 192 & 189 & 182 \\
\hline $\begin{array}{l}\text { Total surveys returned } \\
\text { to contractor }\end{array}$ & 36 & 61 & 58 \\
\hline $\begin{array}{l}\text { Total surveys used in } \\
\text { analysis }\end{array}$ & 34 & 58 & 54 \\
\hline $\begin{array}{l}\text { Last date surveys } \\
\text { received by contractor }\end{array}$ & $5 / 16 / 95$ & $5 / 8 / 95$ & $5 / 19 / 95$ \\
\hline $\begin{array}{l}\text { \% delivered surveys } \\
\text { returned }\end{array}$ & $19 \%$ & $32 \%$ & $32 \%$ \\
\hline $\begin{array}{l}\text { \% surveys used in } \\
\text { analysis }\end{array}$ & $18 \%$ & $31 \%$ & $30 \%$ \\
\hline $\begin{array}{l}\text { Total crashes in time } \\
\text { period during which } \\
\text { crashes selected }\end{array}$ & $\begin{array}{l}10,576 \text { (1993) } \\
3,268 \text { (Main), } \\
1,308 \text { (Sonoma) }\end{array}$ & 11,735 & N/A \\
\hline $\begin{array}{l}\text { Total alcohol-involved } \\
\text { crashes in applicable } \\
\text { time period }\end{array}$ & $\begin{array}{l}659 \text { (1993) } \\
180 \text { (Marin) } \\
470 \text { (Sonoma) }\end{array}$ & 570 & NIA \\
\hline $\begin{array}{l}\text { Total injured in alcohol- } \\
\text { involved crashes }\end{array}$ & $\begin{array}{l}1,002 \text { (1993) } \\
257 \text { (Marin) } \\
745 \text { (Sonoma) }\end{array}$ & 420 & N/A \\
\hline $\begin{array}{l}\text { Total crash victims in } \\
\text { applicable time period }\end{array}$ & $\begin{array}{l}200(1993) \\
48 \text { (Marin) } \\
152 \text { (Sonoma) }\end{array}$ & 201 & N/A \\
\hline $\begin{array}{l}\text { Passengers in drunk } \\
\text { driver's vehicle }\end{array}$ & 80 & 14 & N/A \\
\hline $\begin{array}{l}\text { Driver/occupant of non- } \\
\text { drunk driver's vehicle }\end{array}$ & 120 & 163 & N/A \\
\hline Pedestrians & 0 & 2 & N/A \\
\hline Owners of parked cars & 0 & 22 & $\mathrm{~N} / \mathrm{A}$ \\
\hline
\end{tabular}


classroom activities. Letters were sent to each of these schools and treatment programs and in-person visits were made to each facility.

DUI schools/treatment programs in all four counties agreed to participate in the datacollection activities. Table 2-3 presents complete information on the seven participating programs summarized below:

- Chester County, Pennsylvania - One facility in the county runs both first offender and multiple offender programs.

- Anne Arundel County, Maryland - Three facilities participated, covering both first and multiple offenders.

- Marin County, California -- One facility in the county offers both first offender and multiple offender programs.

- New Castle County, Delaware - One first-offender DUI school (serving New Castle County only) and one multiple-offender DUI program (serving all of Delaware) participated.

Letters of permission were obtained from all seven facilities before data-collection activities were initiated. Calls were then made to each site to arrange the most convenient times for visits to be made to complete the DUI Offender Survey. A complete schedule of visits was maintained over the course of data collection.

The project goal was 200 interviews in each county-150 with first offenders and 50 with multiple offenders. It was estimated that this distribution would mirror the split between first offenders and multiple offenders among those convicted of DUl offenses.

The following instructions were used to introduce the survey to DUI offenders and explain how to complete the survey.

Good evening/morning, my name is

and we are working with (fill in name of organization where survevs being conducted) to determine how your recent DUl arrest has affected your employment. By recent DUI arrest, we mean the one that has resulted in your attendance at this program. We are comparing the effects of losing your license at the time of the DUI arrest with losing your license menths later after judicial proceeedings are complete. Some states already have administrative license revocation (or suspension), where the police officer can take your license at the time of the DUI arrest, but some states do not yet have these DUI laws. (Explain the situation in the state where the survey is being conducted. If this is PA, point out that some questions on page 7 concerning ALR have been omitted in their survey version, since PA does not have ALR) 
Table 2-3. DUI School/Treatment Center Operators Serving New Castle County, DE

\begin{tabular}{|c|c|c|c|c|c|c|c|}
\hline Organization & Classes/Schools & $\begin{array}{l}\text { Type of } \\
\text { Program }\end{array}$ & $\begin{array}{l}\text { Schedule/ } \\
\text { Length of } \\
\text { Class }\end{array}$ & $\begin{array}{l}\text { Hours of } \\
\text { Education }\end{array}$ & $\begin{array}{l}\text { Size of } \\
\text { Class }\end{array}$ & $\begin{array}{c}\text { Time Between } \\
\text { Arrest Date } \\
\text { and When } \\
\text { People Begin } \\
\text { Class }\end{array}$ & Notes \\
\hline 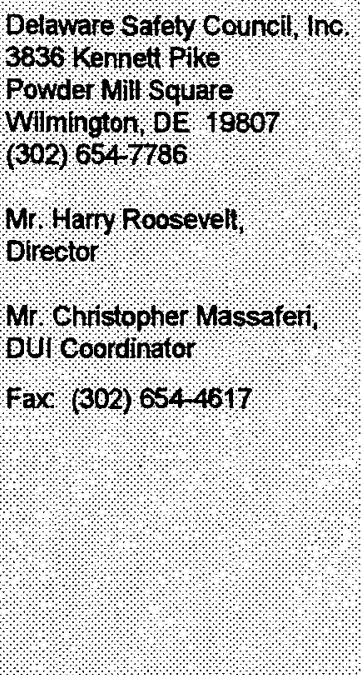 & 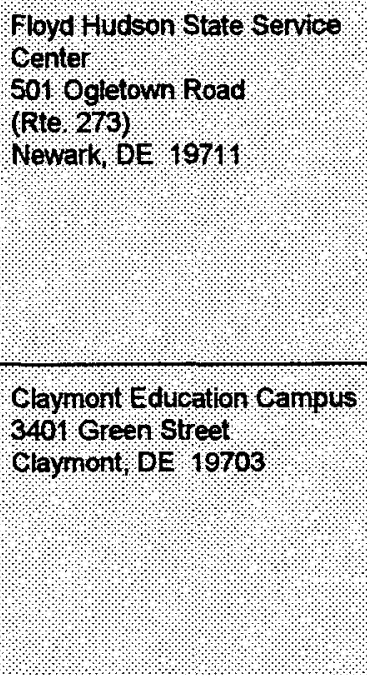 & tistoffender & 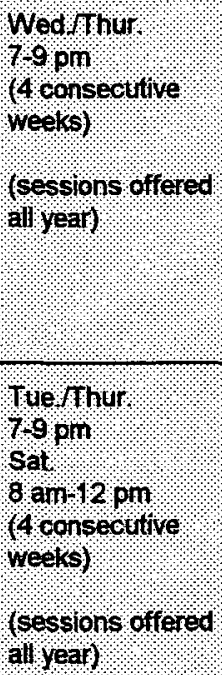 & 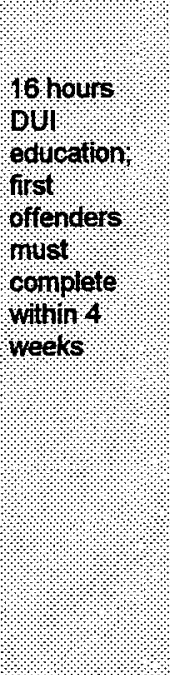 & r & $\begin{array}{l}\text { (t) } \\
\text { on average } \\
\text { somethes } 6\end{array}$ & tै? \\
\hline $\begin{array}{l}\text { Delaware Drinking Driver } \\
\text { Program, Div. of Thresholds } \\
1661 \text { South DuPont Highway } \\
\text { Dover, DE } 19901 \\
\text { (302) 678-0682 } \\
\text { Mr. Walter A. McCann, } \\
\text { President } \\
\text { Mr. Bruce Lorenz, } \\
\text { Director } \\
\text { Fax: (302) 678-1611 } \\
\text { (call above number before } \\
\text { faxing) }\end{array}$ & $\begin{array}{l}\text { Delaware Drinking Driver } \\
\text { Program, New Castle County } \\
\text { Woodmill Corporate Center } \\
5193 \text { W. Woodmill Drive, } \\
\text { Suite } 28 \\
\text { Wilmington, DE } 19808 \\
\text { (302) } 996-5450\end{array}$ & $\begin{array}{l}\text { Individual/Group } \\
\text { Counseling } \\
\\
\text { multiple offenders } \\
\text { chronic offenders } \\
>0.20 \% \text { BAC first- } \\
\text { time offenders }\end{array}$ & $\begin{array}{l}\text { Mon.-Fri. } \\
6-7: 30 \mathrm{pm} / \\
7: 30-9 \mathrm{pm} \\
\text { (Also daytime } \\
\text { and Sat. groups) } \\
21 \text {-hr. individual } \\
\text { sessions, } \\
\text { followed by } \\
81.5 \text {-hr. group } \\
\text { sessions } \\
\text { (sessions offered } \\
\text { all year) }\end{array}$ & $\begin{array}{l}25 \text { hours of } \\
\text { counseling } \\
\text { over } 41 / 2 \\
\text { months }\end{array}$ & $\begin{array}{l}\text { One-on-one } \\
\text { groups up to } \\
15 \text { (average } \\
10 \text { ); } \\
4-5 \text { groups } \\
\text { could meet } \\
\text { on one day }\end{array}$ & $\begin{array}{l}11 / 2 \text { to } 3 \text { months } \\
\text { on average }\end{array}$ & $\begin{array}{l}\text { Received letter of } \\
\text { permission dated } \\
6 / 20 / 94 \text {. }\end{array}$ \\
\hline
\end{tabular}


Table 2-3. DUI School/Treatment Center Operators Serving Anne Arundel County, MD

\begin{tabular}{|c|c|c|c|c|c|c|c|}
\hline Organization & Classes/Schools & $\begin{array}{l}\text { Type of } \\
\text { Program }\end{array}$ & $\begin{array}{l}\text { Schedule/ } \\
\text { Length of } \\
\text { Class }\end{array}$ & $\begin{array}{l}\text { Hours of } \\
\text { Education }\end{array}$ & $\begin{array}{l}\text { Size of } \\
\text { Class }\end{array}$ & $\begin{array}{c}\text { Time Between } \\
\text { Arrest Date } \\
\text { and When } \\
\text { People Begin } \\
\text { Class }\end{array}$ & Notes \\
\hline $\begin{array}{l}\text { Alcohol and Drag recovery } \\
\text { Ltd (ADR) } \\
\text { to7 Ridgely Ave, suite } 15 \\
\text { Annapolis Mo } 21401 \\
(410) 280-2270 \\
\text { Mr Bary Wilen President } \\
\text { rax (410) } 280-2322\end{array}$ & A & ক্ষে & 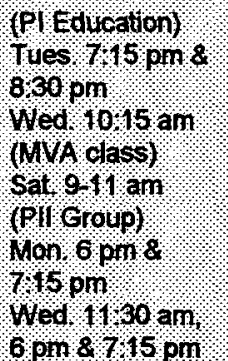 & $\begin{array}{l}\text { 12 hours Pl } \\
\text { Eduodion } \\
\text { ousses } \\
\text { offenders) }\end{array}$ & 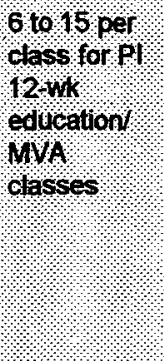 & 3106 months & Recelved letter ol \\
\hline l & 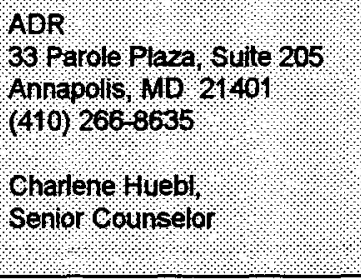 & & 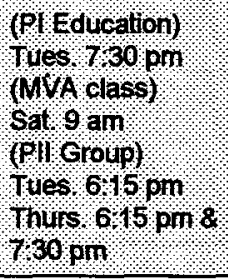 & $\begin{array}{l}14 \text { lours pll } \\
\text { counoup } \\
\text { trepeal } \\
\text { offenders) }\end{array}$ & $\begin{array}{l}\text { Mar of } 10 \\
\text { ror plil groul } \\
\text { coluseling }\end{array}$ & & \\
\hline $\begin{array}{l}\text { Recovery Center of Annapolis } \\
2525 \text { Riva Road, Suite } 107 \\
\text { Annapolis, MD } 21401 \\
\text { (410) 224-3336 } \\
\text { Dr. John McClanahan, } \\
\text { Clinical Director } \\
\text { Fax: (410) 224-2636 }\end{array}$ & $\begin{array}{l}\text { Recovery Center of } \\
\text { Annapolis } \\
2525 \text { Riva Road, Suite } 107 \\
\text { Annapolis, MD } 21401\end{array}$ & $\begin{array}{c}\text { First Offender, } \\
\text { Repeat Offender, } \\
\text { Education Classes } \\
\text { (mixed) }\end{array}$ & $\begin{array}{l}\text { Mon. } \\
\text { 9:30-11:30 am } \\
\text { (6-week cycle) } \\
\text { Mon. } \\
6: 30-8: 30 \text { pm } \\
\text { (6-week cycle) }\end{array}$ & 12 hours & $\begin{array}{l}10 \text { per class } \\
20 \text { per class }\end{array}$ & 3 to 6 months & $\begin{array}{l}\text { Received letter of } \\
\text { permission dated } \\
5 / 28 / 94 \text {. }\end{array}$ \\
\hline
\end{tabular}


Table 2-3. DUI School/Treatment Center Operators Serving Anne Arundel County, MD (Continued)

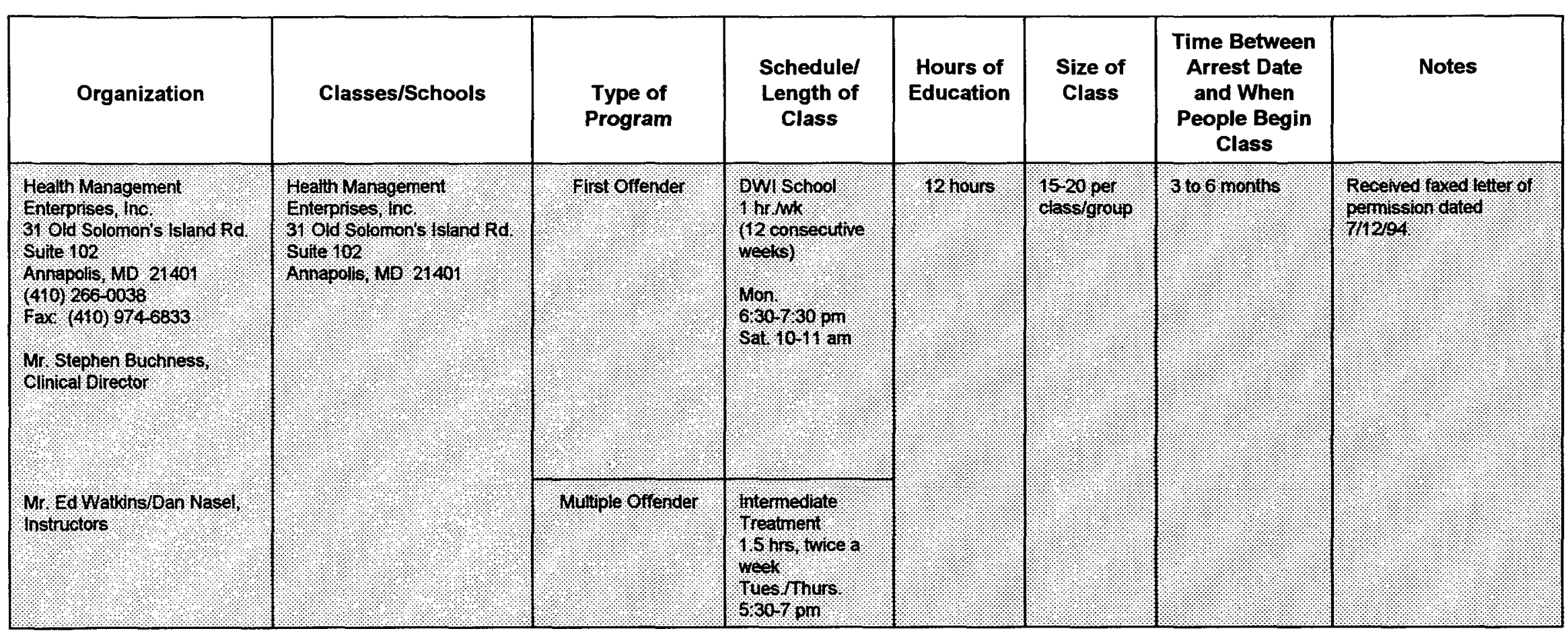


Table 2-3. DUI School/Treatment Center Operators Serving Chester County, PA

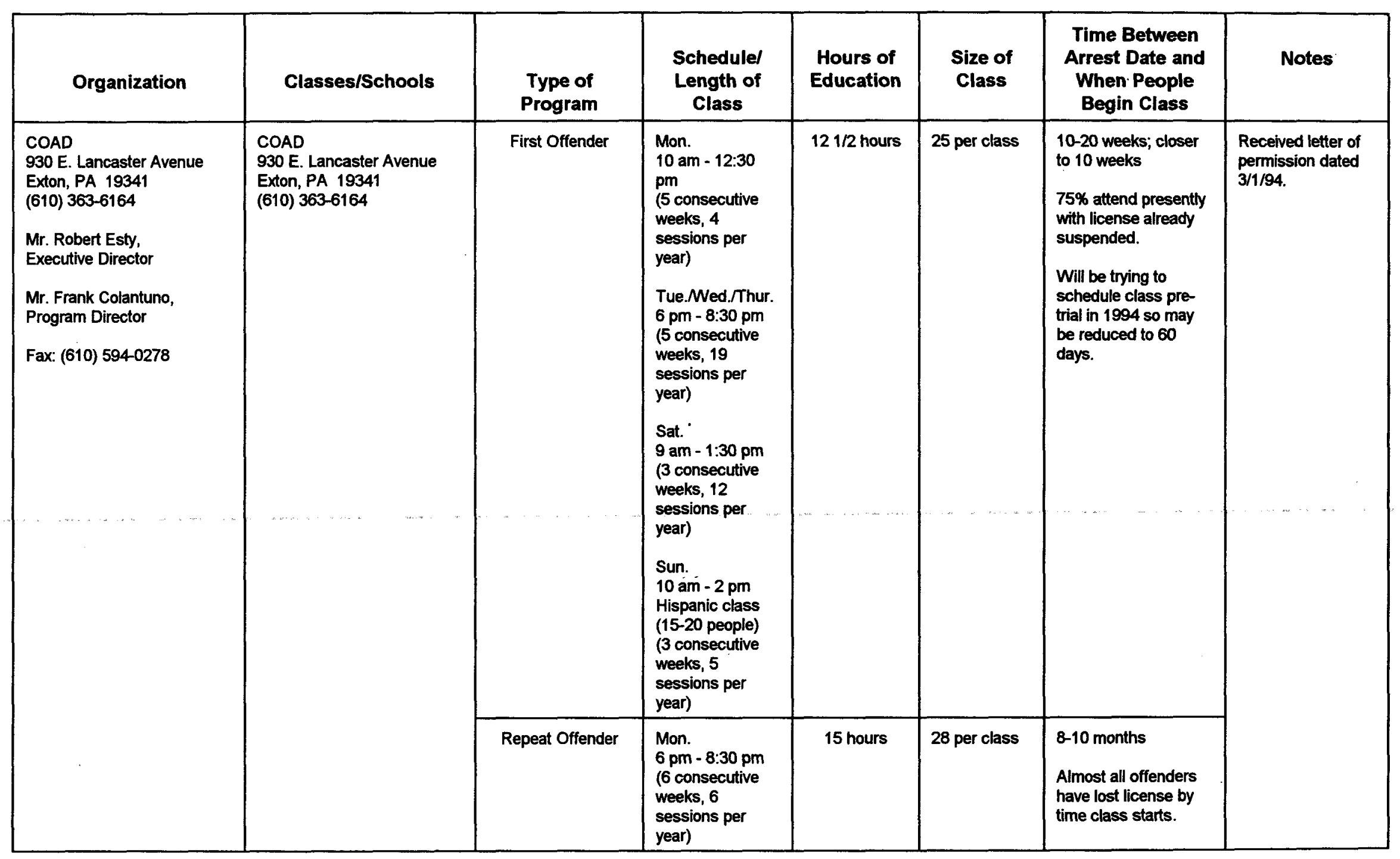


Table 2-3. DUI School/Treatment Center Operators Serving Marin County, CA

\begin{tabular}{|c|c|c|c|c|c|c|c|}
\hline Organization & Classes/Schools & $\begin{array}{l}\text { Type of } \\
\text { Program }\end{array}$ & $\begin{array}{l}\text { Schedule/ } \\
\text { Length of } \\
\text { Class }\end{array}$ & $\begin{array}{l}\text { Hours of } \\
\text { Education }\end{array}$ & $\begin{array}{l}\text { Size of } \\
\text { Class }\end{array}$ & $\begin{array}{c}\text { Time Between } \\
\text { Arrest Date } \\
\text { and When } \\
\text { People Begin } \\
\text { Class }\end{array}$ & Notes \\
\hline \multirow[t]{2}{*}{ 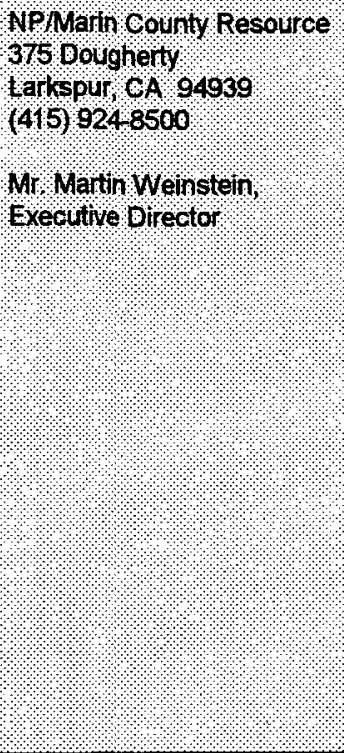 } & \multirow[t]{2}{*}{ 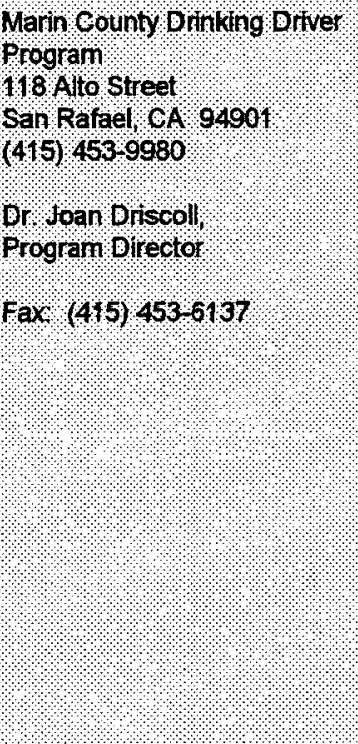 } & first Offender & 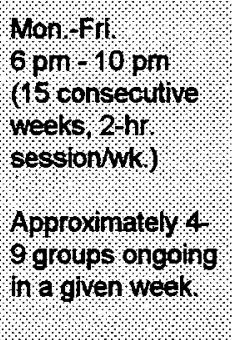 & $\begin{array}{l}12 \text { hours } \\
\text { education } \\
\text { 18 hours of } \\
\text { group } \\
\text { sessions }\end{array}$ & $\begin{array}{l}3035 \text { per } \\
\text { class ior } \\
\text { education. } \\
\text { 15 per group } \\
\text { for treatment }\end{array}$ & $\begin{array}{l}\text { Unable to } \\
\text { determine; court } \\
\text { doess not provide } \\
\text { arrest date } \\
21 \text { days from } \\
\text { conviction to } \\
\text { program } \\
\text { registration }\end{array}$ & \multirow[t]{2}{*}{$\begin{array}{l}\text { Recelved letter of } \\
\text { permission dated } \\
415194\end{array}$} \\
\hline & & Muttiple Offender & 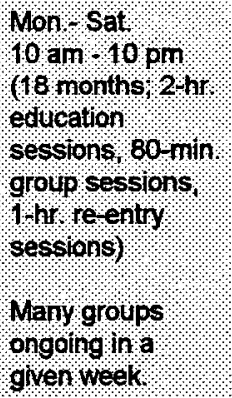 & $\begin{array}{l}12 \text { hours: } \\
\text { education: } \\
52 \text { hours of } \\
\text { group : } \\
\text { sessions: } \\
6 \text { houts of } \\
\text { reenty } \\
\text { counseling }\end{array}$ & $\begin{array}{l}30-35 \text { per } \\
\text { class for } \\
\text { education. } \\
15 \text { per group } \\
\text { lor treatnent }\end{array}$ & 3106 months & \\
\hline
\end{tabular}


You are part of a four-state study. however, this is the only county/school in your state where we are conducting interviews. Therefore, your input and opiniens are very impertant to us. The results of this survey will be used to make recommendations for improvements to DUl laws. This survey will take about 10-20 minutes for you to complete. It is completely anonymous. We are not asking for your name, driver license number. employer names. or any other identifying information. We hope you will answer each question completely and honestly. Please feel free to ask me any questions that you may have while you are completing the survey.

I will now hand out the survey. Please complete page 1 as soon as you receive the questionnaire. I want to go over page 2 before you continue on with that page. IHand out the survey, pencils, and something to wite against; if necessary)

Please turn to page 2, but don't forget to finish page 1 if you have not had a chance to do so. Look at the monthly calendar blocks in the middle of page 2. We would like you to fill in a number from 1.7 for each month from January 1992 to the present (e.g. June 1994) to indicate what you were doing that month. If you were employed at all in a month, enter a "1" in that month's block. Employment is considered any activity from which you received income (cash or check), including fulltime employment, part-time employment, self employment, and military service. If you were going to school in a month, enter a "2". If you were working and going to school in a particular month, enter both a "1" and a "2" in that menth block. The rest of the codes (3-7) are shown above the calendar. Code " 3 " would be used for any months when you were unemployed, during which you were searching for a job "Code "4" denotes months where you were not working of your own choice.

Now look at those months from January 1992 to the present where you entered a " 1 ". If there were no months with " $1 \mathrm{~s}$ " (i.e. you did not work at all from January 1992 to the present), you will skip to question 21 on page 6 . Now think about how many jobs you have had since January 1992 (including the one you were working at the beginning of 1992). If you work for a temp agency and have had many assignments since 1992, this still counts as one job. Also, if you are self-employed (e.g. as a carpenter, electrician, plumber, landscaper, etc) and have worked for many people since 1992, this still counts as one job. How many people have had more than two jobs since January 1992? (Hand out additional copies of page 4 to those with more than 2 jobs.)

On pages 3 and 4 (and any additional pages that I have handed out), we would like you to provide additional information on all the jobs 
represented by the " $1 \mathrm{~s}$ ' In the calendar you just filled out. Use one page for each job. Page 3 is for your current or nest recent job. Page 4 (the buff colored page) would be used for your next most recent job, if you have had two or more jobs since January 1992. If you have only had one job since January 1992, you will skip the buff colored page and go on to page 5. If you held two jobs at the same time (e.g. two part time jebs). use page 3 for one job and page 4 for the other. It is mportant that you complete an employment page for all jobs that correspond to the " $1 \mathrm{~s}$ " that you entered in the activity calendar on page 2.

Remember to go back and complete page 1 if you have not already done so. Note that some questions in the survey may be skipped. based on your response to prior questions. For example, on page 1, question 6 asks whether this was your first DUI arrest. If you answer "Yes" to this question, you are instructed to skip to question 9 (that is, you don't have to answer questions 7 and 8). Please ask me any questions that you may have while completing the survey. There are no "stupid" questions. We have tried to make the survey as clear as possible, but l am sure you will have questions, especially based on unique circumstances that we have not thought of. The reason I am here is to answer questions so that you are able to complete the survey as accurately as possible. Our research is only as good as the information you provide.

We thank you for your participation. We assure you that your input will be used to recommend improvements to DUI laws, with the intention of saving lives.

A total of 73 visits were made to the facilities shown in Table 2-3 in order to complete the desired number of interviews. Data collection spanned the period from June 1, 1994 to October 6, 1994. Table 2-4 presents the schedule followed for these visits, including the number of first offender (FO) and multiple offender (MO) surveys completed during each session. The number of completed surveys is less than the number of surveys returned by participants since incomplete surveys were not kept.

The completed offender surveys are tabulated as follows (including the Hispanic surveys) :

\begin{tabular}{|l|c|c|c|c|}
\hline State & $\begin{array}{c}\text { Total Surveys } \\
\text { Returned by } \\
\text { Participants }\end{array}$ & $\begin{array}{l}\text { First Offender } \\
\text { DUI Complete }\end{array}$ & $\begin{array}{c}\text { Multiple } \\
\text { Offender DUI } \\
\text { Complete }\end{array}$ & $\begin{array}{c}\text { Total DUI } \\
\text { Complete }\end{array}$ \\
\hline Delaware & 232 & 146 & 50 & 196 \\
\hline Maryland & 192 & 96 & 39 & 135 \\
\hline Pennsylvania & 272 & 188 & 66 & 254 \\
\hline California & 340 & 193 & 96 & 289 \\
\hline Total & 1,036 & 623 & 251 & 874 \\
\hline
\end{tabular}


Table 2-4. DUI Offender Survey Administration Schedule

\begin{tabular}{|c|c|c|c|c|c|c|c|c|c|c|}
\hline Visit & $\begin{array}{l}\text { Date of } \\
\text { Survey }\end{array}$ & $\begin{array}{l}\text { Day of } \\
\text { Week }\end{array}$ & $\begin{array}{c}\text { Time of } \\
\text { Class }\end{array}$ & State & Location & FO / MO & $\begin{array}{c}\text { Total } \\
\text { Surveys }\end{array}$ & $\begin{array}{l}\text { Total DUI } \\
\text { Complete }\end{array}$ & $\begin{array}{c}\text { FO DUI } \\
\text { Complete }\end{array}$ & $\begin{array}{c}\text { MO DUI } \\
\text { Complete }\end{array}$ \\
\hline 18 & $6 / 194$ & Wod & $600 \mathrm{pm}$ & $\mathrm{PA}$ & $\begin{array}{l}\text { COAD } \\
\mathrm{Ex} \text { (O) }\end{array}$ & 50 & 31 & 30 & 30 & \\
\hline 2 & $6 / 18 / 94$ & Sat & $9: 00$ am & PA & $\begin{array}{l}\text { COAD } \\
\text { Exton }\end{array}$ & FO & 28 & 27 & 27 & \\
\hline 3 & 623194 & Thu & $700 \mathrm{p}$ & DE & olaymont & 80 & 11 & 10 & 10 & \\
\hline 4 & $6 / 28 / 94$ & Tue & $6: 00 \mathrm{pm}$ & $\overline{P A}$ & $\begin{array}{l}\text { COAD } \\
\text { Exton }\end{array}$ & FO & 29 & 25 & 23 & 2 \\
\hline 5 & $6 / 30 / 94$ & rou & $600 \mathrm{pm}$ & $\mathrm{PA}$ & $\begin{array}{l}\text { COAD } \\
\text { Exon }\end{array}$ & 80 & 34 & 33 & 32 & 1 \\
\hline 6 & $7 / 11 / 94$ & Mon & $9: 30 \mathrm{am}$ & MD & $\begin{array}{c}\text { RC } \\
\text { Annapolis }\end{array}$ & FO/MO & 15 & 4 & 3 & 1 \\
\hline 7 & 711194 & Mon & 630017 & $\mathrm{MO}$ & Annapolis & FONO & 19 & 10 & 5 & 5 \\
\hline 8 & $7 / 12 / 94$ & Tue & $6: 15 \mathrm{pm}$ & MD & $\begin{array}{c}\text { ADR } \\
\text { Annapolis }\end{array}$ & MO & 7 & 5 & 3 & 2 \\
\hline 9 & 7112194 & 108 & $330 \mathrm{pm}$ & No & Annapolls & 80 & 15 & 10 & 9 & 1 \\
\hline 10 & $7 / 13 / 94$ & Wed & $10: 15 \mathrm{am}$ & MD & $\begin{array}{c}\text { ADR Glen } \\
\text { Burnie }\end{array}$ & FO & 4 & 3 & 3 & \\
\hline 18 & 113194 & Wed & 113001 & 14 & ADAGon & 10 & 8 & 7 & 4 & 3 \\
\hline 12 & $7 / 13 / 94$ & Wed & $6: 00 \mathrm{pm}$ & MD & $\begin{array}{c}\text { ADR Glen } \\
\text { Burnie }\end{array}$ & MO & 11 & 8 & 4 & 4 \\
\hline 13 & 113194 & Wod & $715 \mathrm{pm}$ & 10\% & $\begin{array}{l}\text { ADR Gien } \\
\text { Bumie }\end{array}$ & MO & 10 & 8 & 3 & 3 \\
\hline 14 & $7 / 14 / 94$ & Thu & $6: 15 \mathrm{pm}$ & MD & $\begin{array}{c}\text { ADR } \\
\text { Annapolis }\end{array}$ & MO & 10 & 5 & 1 & 4 \\
\hline 15 & 74494 & Thu & $100 \mathrm{pm}$ & $\mathrm{OE}$ & Neswark & 80 & 22 & 18 & 18 & \\
\hline 16 & $7 / 14 / 94$ & Thu & $7: 30 \mathrm{pm}$ & MD & $\begin{array}{c}\text { ADR } \\
\text { Annapolis }\end{array}$ & MO & 4 & 3 & 1 & 2 \\
\hline 17 & 7116194 & sal & $800 \mathrm{am}$ & QE & claymont & 80 & 22 & 19 & 19 & \\
\hline 18 & $7 / 16 / 94$ & Sat & $9: 00 \mathrm{am}$ & MD & $\begin{array}{c}\text { ADR Glen } \\
\text { Burnie }\end{array}$ & FO & 13 & 13 & 13 & \\
\hline 19 & $746 / 94$ & Sal & $1030 \mathrm{an}$ & NO & Annapols & 80 & 4 & 4 & 4 & \\
\hline 20 & $7 / 18 / 94$ & Mon & $6: 00 \mathrm{pm}$ & MD & $\begin{array}{l}\text { ADR Glen } \\
\text { Burnie }\end{array}$ & MO & 11 & 4 & 4 & \\
\hline 21 & 718894 & Mon & $715 \mathrm{pm}$ & MO & AQR Gien & 10 & 2 & 2 & 1 & 1 \\
\hline 22 & $7 / 19 / 94$ & Tue & $5: 30 \mathrm{pm}$ & MD & $\begin{array}{c}\text { HME } \\
\text { Annapolis }\end{array}$ & MO & 9 & 9 & 8 & 1 \\
\hline 23 & 711994 & 10 & $600 \mathrm{pm}$ & $\mathrm{OE}$ & Wilmopon & 110 & 14 & 12 & 11 & 1 \\
\hline 24 & $7 / 19 / 94$ & Tue & $7: 15 \mathrm{pm}$ & MD & $\begin{array}{c}\text { ADR Glen } \\
\text { Burnie } \\
\end{array}$ & FO & 3 & 0 & & \\
\hline 25 & 7119194 & Tue & $830 \mathrm{pm}$ & MO & ADR Glen & 80 & 6 & 4 & 2 & 2 \\
\hline 26 & $7 / 21 / 94$ & Thu & $7: 00 \mathrm{pm}$ & $\mathrm{DE}$ & $\begin{array}{c}\text { DSC } \\
\text { Claymont }\end{array}$ & FO & 9 & 9 & 9 & \\
\hline 27 & 722194 & $\mathrm{Fr}$ & $630 \mathrm{pm}$ & MD & Annapolis & 10 & 5 & 4 & 1 & 3 \\
\hline 28 & $7 / 23 / 94$ & Sat & $10: 00 \mathrm{am}$ & MD & $\begin{array}{c}\text { HME } \\
\text { Annapolis }\end{array}$ & FO & 7 & 5 & 4 & 1 \\
\hline 29 & 7725194 & Mon & $600 \mathrm{pin}$ & $\mathrm{CA}$ & $\begin{array}{c}\text { MeO sar } \\
\text { Ratael }\end{array}$ & 10 & 11 & 6 & & 6 \\
\hline 30 & $7 / 25 / 94$ & Mon & $6: 00 \mathrm{pm}$ & CA & $\begin{array}{c}\begin{array}{c}\text { MCD San } \\
\text { Rafael }\end{array} \\
\end{array}$ & FO & 13 & 13 & 12 & 1 \\
\hline
\end{tabular}


Table 2-4. DUI Offender Survey Administration Schedule

\begin{tabular}{|c|c|c|c|c|c|c|c|c|c|c|}
\hline Visit & $\begin{array}{l}\text { Date of } \\
\text { Survey }\end{array}$ & $\begin{array}{l}\text { Day of } \\
\text { Week }\end{array}$ & $\begin{array}{c}\text { Time of } \\
\text { Class }\end{array}$ & State & Location & FO/MO & $\begin{array}{c}\text { Total } \\
\text { Surveys }\end{array}$ & $\begin{array}{l}\text { Total DUI } \\
\text { Complete }\end{array}$ & $\begin{array}{c}\text { FO DUI } \\
\text { Complete }\end{array}$ & $\begin{array}{c}\text { MO DUI } \\
\text { Complete }\end{array}$ \\
\hline 37 & 72579 & Non & $6,00 \mathrm{pm}$ & $8 \mathrm{~A}$ & Wofsar & Eduo & 22 & 27 & 14 & १? \\
\hline 32 & $7 / 25 / 94$ & Mon & $6: 00 \mathrm{pm}$ & MD & $\begin{array}{c}\text { HME } \\
\text { Annapolis }\end{array}$ & MO & 5 & 5 & 3 & 2 \\
\hline 33 & $7 2 5 \longdiv { 9 4 }$ & 101 & 63001 & MO & AnMe & 80 & 13 & 13 & 11 & 2 \\
\hline 34 & $7 / 25 / 94$ & Mon & 7:00 pm & CA & $\begin{array}{c}\text { MCD San } \\
\text { Rafael }\end{array}$ & MO & 11 & 9 & . & 9 \\
\hline 35 & 72684 & Tuo & $1000 \mathrm{am}$ & 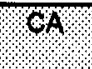 & Metsan & M0 & 13 & 91 & & 11 \\
\hline 36 & $7 / 26 / 94$ & Tue & $6: 00 \mathrm{pm}$ & CA & $\begin{array}{c}\text { MCD San } \\
\text { Rafael }\end{array}$ & FO & 12 & 12 & 11 & 1 \\
\hline 37 & 72684 & Tuo & $6,30 \mathrm{pm}$ & $8 \mathrm{~A}$ & Mos ${ }^{2}$ ara & 10 & 16 & 15 & 95 & \\
\hline 38 & $7 / 26 / 94$ & Tue & 7:00 pm & CA & $\begin{array}{c}\text { MCD San } \\
\text { Rafael }\end{array}$ & MO & 12 & 6 & & 6 \\
\hline 39 & 71279 & Wed & $400 \mathrm{ph}$ & $\mathrm{OA}$ & Meqsan & no & 12 & 9 & & 9 \\
\hline 40 & $7 / 27 / 94$ & Wed & $6: 00 \mathrm{pm}$ & $\mathrm{CA}$ & $\begin{array}{c}\text { MCD San } \\
\text { Rafael }\end{array}$ & FO & 11 & 10 & 10 & \\
\hline 41 & 712719 & Wed & 6000010 & $8 \mathrm{~B}$ & Mo Ratan & Eutucaton & 20 & 19 & 12 & 7 \\
\hline 42 & $7 / 27 / 94$ & Wed & $6: 00 \mathrm{pm}$ & $\mathrm{CA}$ & $\begin{array}{c}\text { MCD San } \\
\text { Rafael }\end{array}$ & FO & 11 & 11 & 11 & \\
\hline 43 & 712719 & Wed & $700 \mathrm{pm}$ & $\mathrm{CA}$ & $\begin{array}{l}\text { Mopsan } \\
\text { ratael }\end{array}$ & 80 & 11 & 9 & 9 & \\
\hline 44 & $7 / 28 / 94$ & Thu & $6: 00 \mathrm{pm}$ & CA & $\begin{array}{c}\text { MCD San } \\
\text { Rafael }\end{array}$ & FO & 8 & 6 & 6 & \\
\hline 85 & 112898 & Tho & $5 \% 00 \mathrm{pm}$ & 8 & $\begin{array}{l}\text { Mensan } \\
\text { Rataspanta }\end{array}$ & Mo & 14 & 13 & & 13 \\
\hline 46 & $7 / 28 / 94$ & Thu & $6: 00 \mathrm{pm}$ & $\mathrm{CA}$ & \begin{tabular}{c|} 
MCD San \\
Rafael - \\
Vietnamese
\end{tabular} & $\mathrm{FO} / \mathrm{MO}$ & 3 & 1 & 1 & \\
\hline 47 & 729194 & 81 & $10008 \mathrm{~m}$ & 8 & MCAsan & MO & 10 & 8 & & 8 \\
\hline 48 & $7 / 30 / 94$ & Sat & $10: 00 \mathrm{am}$ & CA & $\begin{array}{c}\text { MCD San } \\
\text { Rafael - } \\
\text { Hispanic }\end{array}$ & FO & 11 & 11 & 10 & 1 \\
\hline 49 & $6 / 294$ & 960 & $600 \mathrm{pm}$ & $\mathrm{DE}$ & WoOphoptory & Mo & 10 & 7 & & 7 \\
\hline 50 & $8 / 2 / 94$ & Tue & 7:30 pm & DE & $\begin{array}{c}\text { DDDP } \\
\text { Wilmington }\end{array}$ & MO & 15 & 9 & 9 & \\
\hline 51 & 81114 & Thu & $6,00 \mathrm{pm}$ & BE & WoOphor & MO & 11 & 10 & & 10 \\
\hline 52 & $8 / 11 / 94$ & Thu & $7: 00 \mathrm{pm}$ & $D E$ & $\begin{array}{c}\text { DSC } \\
\text { Newark }\end{array}$ & FO & 21 & 19 & 19 & \\
\hline 58 & 8113194 & Sal & $8000 \mathrm{~m}$ & $\mathrm{BE}$ & Olase & $\mathrm{PO}$ & 18 & 17 & 17 & \\
\hline 54 & $8 / 16 / 94$ & Tue & $6: 00 \mathrm{pm}$ & PA & $\begin{array}{l}\text { COAD } \\
\text { Exton }\end{array}$ & FO & 33 & 33 & 33 & \\
\hline 55 & 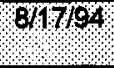 & Wed & $600 \mathrm{pm}$ & $\mathrm{DE}$ & Wo imington & Mo & 10 & 9 & 3 & 6 \\
\hline 56 & $8 / 18 / 94$ & Thu & $6: 00 \mathrm{pm}$ & PA & $\begin{array}{l}\text { COAD } \\
\text { Exton }\end{array}$ & FO & 24 & 22 & 22 & \\
\hline 57 & 811819 & This: & $100 \mathrm{pm}$ & $8 \mathrm{OC}$ & $\begin{array}{l}\text { osc } \\
\text { claymont }\end{array}$ & $\mathrm{FO}$ & 9 & 8 & 8 & \\
\hline 58 & $8 / 23 / 94$ & Tue & $6: 00 \mathrm{pm}$ & $\mathrm{DE}$ & \begin{tabular}{|c|} 
DDDP \\
Wilmington
\end{tabular} & MO & 15 & 10 & 4 & 6 \\
\hline 59 & 629194 & Mon & $1000 \mathrm{am}$ & bA & QOAO & $F$ & 21 & 78 & 91 & 7 \\
\hline
\end{tabular}


Table 2-4. DUI Offender Survey Administration Schedule

\begin{tabular}{|c|c|c|c|c|c|c|c|c|c|c|}
\hline Visit & $\begin{array}{l}\text { Date of } \\
\text { Survey }\end{array}$ & $\begin{array}{l}\text { Day of } \\
\text { Week }\end{array}$ & $\begin{array}{c}\text { Time of } \\
\text { Class }\end{array}$ & State & Location & $\mathrm{FO} / \mathrm{MO}$ & $\begin{array}{c}\text { Total } \\
\text { Surveys }\end{array}$ & $\begin{array}{l}\text { Total DUI } \\
\text { Complete }\end{array}$ & $\begin{array}{c}\text { FO DUI } \\
\text { Complete }\end{array}$ & $\begin{array}{c}\text { MO DUI } \\
\text { Complete }\end{array}$ \\
\hline 60 & $8 / 29 / 94$ & Mon & $6: 00 \mathrm{pm}$ & $\overline{P A}$ & $\begin{array}{l}\text { COAD } \\
\text { Exton }\end{array}$ & MO & 31 & 26 & & 26 \\
\hline 61 & $829 / 94$ & Non & $700 \mathrm{pm}$ & $\mathrm{BA}$ & EOAD & Mo & 27 & 26 & & 26 \\
\hline 62 & $9 / 13 / 94$ & Tue & $7: 30 \mathrm{pm}$ & $\mathrm{DE}$ & $\begin{array}{c}\text { DDDP } \\
\text { Wilmington }\end{array}$ & MO & 13 & 11 & & 11 \\
\hline 63 & $9 / 15 / 94$ & Thu & $1000 \mathrm{pm}$ & $\mathrm{DE}$ & clasmons & 80 & 9 & 8 & 8 & \\
\hline 64 & $9 / 17 / 94$ & Sat & $8: 00 \mathrm{am}$ & DE & $\begin{array}{c}\text { DSC } \\
\text { Claymont }\end{array}$ & FO & 13 & 11 & 11 & \\
\hline 65 & $9 / 19 / 94$ & $\mathrm{Non}$ & 93011 & $\mathrm{MP}$ & An Ropolis & POMO & 11 & 11 & 9 & 2 \\
\hline 66 & $9 / 22 / 94$ & Thu & $7: 30 \mathrm{pm}$ & DE & $\begin{array}{c}\text { DDDP } \\
\text { Wilmington }\end{array}$ & MO & 10 & 9 & & 9 \\
\hline 67 & $9 / 2594$ & sun & $1000 \mathrm{am}$ & $\mathrm{PA}$ & $\begin{array}{l}\text { CoAD } \\
\text { Exton }\end{array}$ & FOMO & 14 & 14 & 10 & 4 \\
\hline 68 & $10 / 3 / 94$ & Mon & $6: 00 \mathrm{pm}$ & $C A$ & $\begin{array}{c}\text { MCD San } \\
\text { Rafael }\end{array}$ & $\begin{array}{l}\text { FO-MO I } \\
\text { Education }\end{array}$ & 28 & 23 & 14 & 9 \\
\hline 69 & $10 / 4194$ & Tue & $600 \mathrm{pm}$ & $\mathrm{CA}$ & Meqsan & 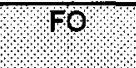 & 11 & 9 & 9 & \\
\hline 70 & $10 / 4 / 94$ & Tue & $6: 30 \mathrm{pm}$ & CA & $\begin{array}{c}\text { MCD San } \\
\text { Rafael }\end{array}$ & FO & 12 & 11 & 11 & \\
\hline 71 & $10 / 5 / 94$ & Wed & $1800 \mathrm{pm}$ & $\mathrm{CA}$ & $\begin{array}{l}\text { MeO San } \\
\text { Rafael }\end{array}$ & Education & 34 & 32 & 30 & 2 \\
\hline 72 & $10 / 6 / 94$ & Thu & $6: 00 \mathrm{pm}$ & $\mathrm{CA}$ & $\begin{array}{c}\text { MCD San } \\
\text { Rafael }\end{array}$ & FO & 28 & 21 & 12 & 9 \\
\hline 73 & $10 / 6 / 94$ & Thu & $700 \mathrm{pm}$ & 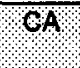 & $\begin{array}{l}\text { Mes san } \\
\text { Rafael }\end{array}$ & 80 & 6 & 6 & 6 & \\
\hline
\end{tabular}

\subsection{Data Processing and Descriptive Statistics}

Procedures were developed to check every offender and victim survey (before data entry) for completeness. The same person checked all surveys so that consistent editing was used. An offender survey status sheet was developed to track (in time order) the number of surveys completed at each scheduled class/program at each facility. The victim surveys were tracked by the date they were received.

A PC-based data-entry program was developed for the keying and verifying of both offender surveys and victim surveys. Offender surveys were keyed for all complete questionnaires. Surveys could not be used if any one of the following conditions were met: (1) the offender did not attend the program as a result of a DUI arrest; (2) the arrest date is missing; (3) the arrest date was before January 1, 1992 (prearrest data was not available for impact analysis); or (4) employment information was not provided for jobs held in 1992/1993/1994. After surveys were excluded according to one of the above criteria, the final number of surveys used in the analysis was as follows. 


\begin{tabular}{|l|c|c|c|}
\hline \multicolumn{1}{|c|}{ State } & $\begin{array}{c}\text { Final First Offender } \\
\text { Surveys }\end{array}$ & $\begin{array}{c}\text { Final Multiple } \\
\text { Offender Surveys }\end{array}$ & $\begin{array}{c}\text { Total } \\
\text { Surveys } \\
\text { Pennsylvania }\end{array}$ \\
\hline Maryland & 168 & 65 & 233 \\
\hline California & 96 & 38 & 134 \\
\hline Delaware & 171 & 83 & 254 \\
\hline Total & 144 & 47 & 191 \\
\hline
\end{tabular}

After the surveys were keyed and verified, descriptive statistics were produced that listed all responses to each question on both surveys. All "outliers" were identified and extensive data cleaning was employed to assure that all survey data were entered correctly. Since the survey respondents could not be contacted to correct any suspect answers, any survey responses that appeared to be extreme were coded as missing so they would not be included in the final analysis.

After all data-cleaning activity was complete, statistical tables were produced for all questions on both surveys. The open-ended question concerning the effect of the DUI arrest/crash on the respondent's employment and income was coded into distinct categories for presentation purposes. Cross tabulations of the offender survey data were produced that showed the distribution (frequency and percent) of survey responses by state and offender type, ALR status in state, current job type, need to use a vehicle for employment, and loss of license status. Cross tabulations of the victim survey data were produced that showed the distribution (frequency and percent) of survey responses by state and treatment of injuries.

Appendix D contains the DUI offender survey statistical tabulation by state and DUI offender type. Appendix E contains the crash victim survey statistical tabulation by state and treatment of injuries.

\subsection{ALR Process/DUI Sanction Review}

In order to understand the DUI sanction environment operating in each of the study states, a process review was conducted of the DUI laws and procedures in each state. Topic guides were completed (either by telephone interview or mail) by the cognizant individuals in each state. The following subsections present the responses to the questions posed in these topic guides.

\subsubsection{California ALR Process Review}

The following information on California's ALR process was provided by:

1. Joan Driscoll, Marin County Drinking Driver Program; 
2. Mike Woods, Director of CADDTP (an association of treatment programs);

3. Frank Cox, Marin County public defender;

4. Linda Robinson, Department of Motor Vehicles; and

5. Cliff Helander, Department of Motor Vehicles, Sacramento, California.

1. What are the conditions of DUI arrest (BAC level, test refusals, passive methods)?

The conditions of DUI arrest are based on a test showing $0.08 \%$ or more BAC, or a refusal to lake the test. (Some members of the groups said they have had blood extracted forcefully). Refusal is not a crime, but may be a violation of conditions of probation. There is no current use of passive methods.

2. When is the DUl offender's permanent license taken away? Is it suspended or revoked?

The Dul offender's permanent license is taken away at the scene of the arrest. The license is suspended for 120 days.

3. Is a temporany license issued? How long is it good for?

A temporary license is issued at the scene of arrest and is valid tor 30 days as of 11194 ( 45 days previously).

4. What is the process for requesting an administrative hearing?

An administrative hearing must be requested within 10 days.

5. Is action stayed until a hearing is held?

Action is not stayed for the hearing.

6. Is police presence required at the hearing?

Police presence is not required at the hearing; a written statement by the arresting officer suffices. The administrative hearing has traditionally been held in Sacramento and now is held in several other offices.

7. Are hearings permitted by telephone? Can testimony be submitted by affidavit?

Telephone affidavit is not allowed at administrative hearings. However, officer testimony is written.

8. What are the possible results of a hearing (e.g, suspension upheld, license restored)?

The result of an administrative hearing may be that the driver's license is restored if police lacked probable cause for arrest, if the citizen at the hearing was not driving, or if the BAC was not $0.08 \%$ or nore. 
9. What percent of DUI administrative actions are appealed and what ane the success rates?

Of administrative per se (APS) actions in 1992 and $1993.9 \%$ resulted in a hearing. In 1992. the APS suspension was upheld in $86 \%$ of the BAC or refusal administrative hearings held. In 1993, the APS suspension was upheld in $76 \%$ of the BAC or refusal administrative hearngs held.

10. What is the length of license suspension if no hearing or hearing supponts suspension)?

Suspension periods are: (1) first offense is 4 months based on the BAC test or 1 year for test refusal; and (2) repeat offenses are 1 year based on the BAC test or 2 years for test refusal. However. the standard requirement for multiple offenders is completion of DUI program, which takes 18 months. A work permit is avallable to multiple offenders after 12 months.

11. What are the conditions 10.9 . employment only) and timing tor obtaining a hardship/restricted license?

Restricted license conditions are: (1) After 30 days, first offenders may apply for a restricted license for participation in the Dul program only, but not for driving to work However some judges appear to think that driving to work is permitted (relevant if someone is charged with driving while suspended). Pending legislation (S B. 1758) would give first offenders a work permiti and (2) Multiple offenders may apply for a restricted license permit to drive to work and to the DUI program after 1 year.

12. Must all DUI offenders attend school? When? For how long?

Aftendance at DUI school is mandatery except for the very few who do not receive a fudicial order. DUl school follows conviction. DUl offenders must register for the program within 21 days. DUI school lasts for 15 weeks for first offenders and 18 months for multiple offenders.

\section{Must the DUI oftender perform community senvice?}

Multiple offenders must complete 24 hours of service in Marin County, however, this is not uniform statewide.

14. How does community service affect the length of license suspension?

Community service does not affect the length of suspension.

\section{What are the conditions and timing tor the restoration of a permanent license?}

The conditions and timing for permanent license restoration are different for first and multiple offenders. First offenders must wait for passage of 90 days trom the effective date of suspension and receipt of notice of program completion (the latter is often ignored in practice). Multiple offenders must wail for passage of 12 months and completion of program (note that a work permit can be obtained before full license restoration). 
16. When discretion is allowed at any point in the sanction process, how is it applied?

No discretion is permitted in this process.

\subsubsection{Delaware ALR Process Review}

The following information on Delaware was obtained during the contractor's recent evaluation of Delaware's DUI Program (Knoebel, Ross, Schmidt, and Decina, 1995).

1. What are the conditions of DUI arrest (BAC level, test refusals, passive methods)?

The conditions of DUI arrest are (1) probable cause to stop person; (2) a preponderance of evidence that person was driving under the influence of alcohol, (3) a BAC of $0.10 \%$ or above constitutes conducive evidence; or (4) a refusal to submit to chemical test:

2. When is the DUI offender's permanent license taken away?

At the time of the arrest the officer takes the plastic license from the driver: A 15 -day temporany (paper) license is given to the driver at that time.

3. Is it suspended or revoked?

If, as a result of the administrative hearing, the person is to lose their driving privileges, the license is revoked.

4. Is a temporany license issued?

A temporary license is issued at the time of the arrest if the officer takes the plastic license from the driver. If the driver does not have his license in his/her possession. no temporary license is issued:

5. How long is the temporany license good for?

A temporary license is good for 15 days initially. If the person requests an administrative hearing, the temporary license is extended for 60 days. If for some reason no decision has been made within the 60 -day period the temporary license is extended until a determination is made concerning the driver's privileges.

6. What is the process for requesting an administrative hearing?

The administrative hearing request must be in writing and must be submitted to the Department of Motor Vehicles (DMV) within 15 days following the date of arrest. The DMV also has a form which can be filled out to request a hearing if the person chooses to appear at the DMV to complete the form. No requests are taken by telephone. None are taken after the 15 th day. 
7 . Is action stayed until a hearing is held?

Yes. action is stayed until a hearing is held . No action will be taken with reference to the administrative revocation until the hearing is held and it is determined that the hearing is to be ruled against the driver.

8. Is police presence required at the heanng?

Police presence is required at the administrative hearing. (As per Sweeney v. Motor Vehicle Commissioner, 257 A , 2nd 764, Del Super, 1969)

9. What are the consequences if police fail to appear?

The hearing is ruled in favor of the person if the police do not appear.

10. Are hearings permitted by telephone?

Tearings are not permitted by telephone.

1. Can testimony be submitted by affidavit?

Testimony can not be submitted by affidavit.

12. What are the possible results of a hearing $(e, g$, suspension upheld, license restored)?

The possible results of a hearing are. (1) revocation of the license is initiated, or (2) no action taken and the license is sent back to person.

13. What percent of QUI administrative actions are appealed and what are the success rates?

Approximately $2 \%$ of all administrative hearings are appealed and out of the $2 \%$, less than $1 / 2 \%$ are ruled against DMV and thus have to be reinstated.

14. What is the length of license revocation (if no heaning or hearing supports revocation)?

Revocation periods for the first offender are 3 months for test failure or 1 year for test refusal. Second offender revocation periods are 1 year for test failure or 18 months for test: refusal. Third offense revocation is 18 months for test failure or 2 years for test refusal.

15. What are the conditions (e.g., employment only) and timing for obtaining a hardship/restricted license?

Only first offender elections through the court system are allowed a conditional license. The driver may make application for a conditional license with the completion of 16 hours of a program (and payment of same), license must have been surrendered to DMV for at: least 90 days, and they must have completed a favorable background review, Fee is $\$ 10$ An application form is completed. No follow up is done. There are no specific requirements for approval of the conditional license. 
16. Must all DUI offenders attend school? When?

Dul offenders must attend sehool or a treatment program. They must contact the evaluation agency within 72 hours of the court decision requiring this attendance. They will be evaluated as soon as possible and enrolled in an appropriate program as soon as space becomes available.

17 For how long?

First offenders must attend 16 hours of class. Multiple offenders, those with more than $0.20 \% \mathrm{BAC}$, and chronic offenders must attend a more intensive program lasting 18 months.

18. Must the DUl offender perform community service?

DUl offenders do not need to perform community service:

19. How does community service affect the length of license revocation?

Community service has no effect on the length of license revocation.

20. What are the conditions and timing for the restoration of permanent license?

Restoration of the permanent license will be made when (1) a minimum revocation time has been served: (2) all tines are paid: (3) a background review is favorable; (4) the recommended program is completed successfully; and (5) a reinstatement fee is paid.

21. When discretion is allowed at any point in the sanction process, how is it applied?

All revocation periods, school requirements and reinstatement procedures are outlined by law. There is no discretion allowed in these areas. The only time discretion is evident in the process is at the time of reinstatement when a background review is done. The extent of the review is discretionary as well as the results (recommendations) of the review.

\subsubsection{Maryland ALR Process Review}

The following information on Maryland was provided by Lucile Haislip, Assistant Director, Division of Administrative Adjudication.

1. What are the conditions of OUI arrest (BAC level, test refusals, passive methods)?

The conditions for DUl arrest are: (1) the police officer has probable cause to believe that the person was operating or attempting to operate a motor vehicle on the highways under the influence of intoxicating liquor or drugs; and (2) the driver took a breath test and failed (alcohol concentration of $0.10 \%$ or more) or refused to submit to a chemical test: 
2. When is the OUl offenders pemanent license taken away?

The DUl offender's permanent license is taken away by the police officer at the time of: arrest:

3. Is it suspended or revoked?

The DUI offender's license is suspended.

4. Is a temporary license issued?

A temporany license is issued.

5. How long is the temporany license good for?

The temporary license is good for 45 days.

6. What is the process for requesting an administrative heaning?

To stop the suspension from becoming effective on the 46 th day after arrest, an administrative hearing nust be requested within 10 days from the order of suspension. date. . However. the DUI offender has 30 days in which to request an administrative hearing.

7. Is action stayed until a hearing is held?

Action can be delayed if a hearing is requested within 10 days.

8. Is police presence required at the heaning?

Police presence is required only if subpoenaed by administration due to questionable information on the order of suspension or if the administrative law udge requests the testimony of the police officer:

9. What are the consequences if police fall to appear?

If the arresting officer fails to appear at the hearing, the case is usually dismissed:

10. Are hearings permitted by telephone?

Hearings are not permitted by telephone.

11 Can testimony be submitted by afidavit?

Testimony can not be made by affidavit. 
12. What are the possible results of a hearing $(\theta, 9 .$, suspension upheld, license restored)?

The result of a hearing may be: (1) the suspension is upheld (person falls lo appear or evidence supponts suspension), (2) the full license is restored (evidence does not support suspension or police fail to appear if requested to attend), or ( 3 ) a restricted license is issued for employmenteducational reasons if the suspension was the result of a first test failure.

13. What pencent of DUI administrative actions are appealed and what are the success rates?

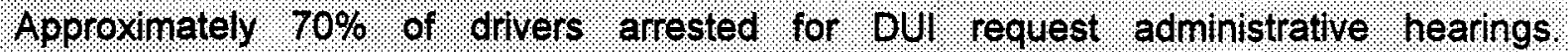
Approximately $5 \%$ of administrative law judge's decisions are appealed to the eircuit court, the appeal success rates are not known.

14. What is the length of license suspension (if no hearing or hearing supports suspension)?

A first refusal results in a 120 day suspension, a second or subsequent refusal results in a 1 year suspension. A first test fallure results in a 45 day suspension and a second test failure results in a 90 -day suspension.

15. What are the conditions (e.g., employment onty) and timing for obtaining a hardship/restricted license?

Maryland law does nol allow for a restricted license or a modification of suspension when a person refuses a chemical test for a test failure, a restricted license may be issued if proof is submitted to the administrative law judge that the person must drive in the course of employment or to attend school: The restricted license is valid from dawn to dusk.

16. Must all DUl offenders attend school? When? for how long?

Administrative law judges may require a DUl offender to attend a 12 -hour alcohol education program (based on the prior driving record). Approximately $60 \%$ of DUI offenders are referred to such a program. The alcohol education program is a 12 hour program (typically held 2 hours/week for 6 consecutive weeks). The alcohol treatment counseling program is a 26 -hour program and may be required for multiple offenders.

\section{Must the DU1 offender perform community service?}

Community service could be a condition of a criminal sentence (court trial), but not of the administrative process.

18. How does community service affect the length of license suspension?

Community service has no effect on license suspension.

19. What are the conditions and timing for the restoration of permanent license?

Restoration of permanent license occurs when the suspension period has expired or restriction time has been served. 
20. When discretion is allowed at any point in the sanction process; how is it applied?

Biscretion is only applied by an administrative law ludge on test tailures where a restricted license or modification of suspension is permitted. No discretion is allowed on refusals.

\subsubsection{Pennsylvania DUI Process Review}

The following information on Pennsylvania was provided by Chester County Council on Addictive Diseases, Inc.

1. What are the conditions of DUI arrest?

Conditions of DUI arrest include: probable cause to stop vehicle and BAC>0.10\%, refused chemical test, or BAC 0.050.09\% and failed field sobriety tests.

2. When is the DUI offender's permanent license taken away?

Seven days after the DUI arrest, a preliminary hearing is held. At that time, a court date is set for 45.60 days in the future. If a DUI conviction is obtained or the offender is granted Accelerated Rehabilitative Disposition (ARD), the plastic license is surrendered at the time of the court dateltrial.

3. Is it suspended or revoked?

The DUI offenders permanent license is suspended for first offenders and revoked for habitual offenders.

4. What is the length of license suspensiontrevocation?

ARD election (First Offender): Base license suspension is a function of the BAC.

$0.05-0.14 \% \mathrm{BAC} .3$ months suspension

$0.15-0.19 \%$ BAC : 4 months suspension

$0.20 \cdot 0.24 \%$ BAC 5 months suspension (unknown BAC is placed in this category)

$0.25-0.29 \%$ BAC $: .6$ months suspension

$0.30 \cdot 0.34 \% \mathrm{BAC}: 7$ months suspension

$0.35 \%$ BAC and above 8 months suspension

50 hours of community service reduces the above suspension by 1 month. 100 hours of community service reduces the above suspension by 2 months. Participation in an ignition interlock program for 6 months reduces the above suspension by 2 months. A new Fast Track program waives community service/ignition interlock for those DUI offenders who finish the required alcohol highway safety class within 60 days.

First DUI conviction/test refusal: 12 months suspension Judicial and/or PennDOT discretion applied) 
Second DUl convictiontest refusal: 12 nonths suspension ninimum with a 2 year parole period (udicial andior PennDOT discretion applled)

Third Dul convictiontest refusal (within a 5-year period) 5 -year license revocation as an Habitual Offender . Any additional DUl convictions within the 5 year period add 2 years to the license revocation period.

5. What fines are imposed for a DUl conviction?

A $\$ 300$ minimum tine is imposed for a DUI conviction.

6. What terms of imprisonment are served for a DUl offense?

ARD election: 1.18 .8 None

First DUl conviction: 18.88 consecutive hours

Second DUI conviction: 30 days.

Third DUl conviction : 190 days

Fourth PUl conviction: 1 year

The time period within which second, third, and fouth oul convictions are determined is? years. AA ARD election counts as a first conviction for determining the applicable /ail time.

7. What are the conditions $(e \mathrm{~g}$. employment only) and timing for obtaining a hardship/restricted license (if one is available)?

An occupational limited license may not be issued to anyone convicted of DUI granted ARD for DUI, or whose ficense was suspended for refusing to submit to a chemical test.

8. Must all DUI offenders attend school? When? for how long?

All DUl offenders must attend school at some point after arrest, prior to completion of the probationary period. First offenders attend for 12.5 hours and multiple offenders attend for 15 hours.

9. Must the DUt offender perform community service?

Community service is not required.

10. How does community service affect the length of license suspension?

50 hours of community service reduces an ARD license suspension by 1 month. 100 hours of community service reduces an ARD license suspension by 2 months. Community service is now waived for ARD if the DUl offender completes the alcohol highway safey school within 60 days. 


\section{What are the conditions and timing for the restoration of the permanent license?}

Restoration of the permanent license requires completion of all program requirements including: Court Reporting Network (CRN) evaluation, alcohol highway safety school, inpatient or outpatient treatment or counseling (if ordered); community service (if elected as part of ARD program), and prescribed license suspension period served. All requirements are at the discretion of PennBOT, the presiding Judge, and the Adult Probation Department:

12. When discretion is allowed at any point in the sanction process, how is it applied?

See question 11 above.

\subsection{Methodology for Estimating Impact on Employment}

The goal of the methodology is to obtain clear cause-and-effect linkages between variables. In this case, the researchers aimed to link any employment differences found among the four jurisdictions to the legal variable, which was hypothesized as potentially causal. It was expected that differences in employment levels for DUI offenders would be related to differences in administrative license consequences. In particular, it was expected that the states would line up with Delaware at one end, having the longest period of hard suspension; then California, with an initial period of hard suspension, followed by a longer one in which drivers could obtain limited licenses; then Maryland, where hardship licenses were obtainable at any time; and finally Pennsylvania, which lacks administrative license revocation.

The general problem for social science methodology is that the social world is filled with potentially causal factors and it is usually difficult to assert with confidence that any one factor or combination of factors is a necessary or sufficient cause of changes in another. The classic solution to this problem is the randomized group experiment, in which subjects are equated through randomization on all variables except the experimental one. If license revocation could be given out in various lengths according to random selection, it could be concluded that subsequent differences in employment were due to the license actions. However, in this case, and in legal studies more generally, it is not possible to apply laws and penalties in a random manner. Practical difficulties preclude this, and law application is governed by the principle that like cases should be treated alike, which is precisely what is not done when random differences are applied.

An alternative to randomization, when the latter is unavailable, is selection of cases in a way to maximize their comparability. Although the researcher has no control over application of the experimental condition, he or she may have control over selection of cases for the study. This "quasi-experiment" is not as good a method as randomization because some potentially valid alternative interpretations of differences often remain. However, it may represent the best that can be done in a situation, and is far better than 
selecting cases haphazardly. The researchers used this principle in selecting the counties observed in Pennsylvania, Delaware, and Maryland. Counties were selected in these three neighboring states as a means of minimizing differences in population composition, climate, road network, and general culture. This match was confirmed by statistical analysis of the three jurisdictions. The counties were as close on the socio-economic indexes as reality permitted. Since there was no adjacent or even close state with the policy of a short hard suspension followed by a longer soft one, Marin County, California, was included in the study. Although regional differences remain a bothersome potential in explaining differences between California and the other three states, the county was selected to duplicate as closely as possible the socio-economic environment of the other three counties. The researchers believe they were successful in this attempt.

Control over irrelevant variables can also be attempted by statistical means. This also is not an ideal solution to the control problem because only those variables thought of and measured can be controlled, and it is always possible that something not envisaged produced the difference in question. An example of a statistical control would be to weight populations known to differ in racial composition in order to hold constant the influence of race on some other characteristic. Statistical controls were used in the analysis for such matters as age and gender.

As it turned out, there did not appear to be a systematic and important effect of the different DUI laws in the states studied. It was also assumed that criminal sanctions, treatment, etc. took place after the ALR period of evaluation, so their effects were not considered. Since there is little or no relationship to be explained, erroneous cause-andeffect conclusions are avoided. Regrettably, valid cause-and-effect conclusions are also avoided, but this represents the state of the world as it was observed.

Appendix $F$ contains a detailed statistical explanation of the design of the evaluation that was used in this research project to estimate the impact of ALR on employment. 


\subsection{ANALYSIS AND INTERPRETATION OF RESEARCH FINDINGS}

\subsection{Who are the DUI Offenders and Their Victims?}

As has been found in other studies, the DUI offenders were atypical of the general population. Even first offenders differ socio-demographically from the general population, and the multiple offenders were even less representative. Parameters of the DUI offender populations are compared with the "victim" samples and, where available, Census figures for the counties in question in Table 3-1.

Table 3-1. Characteristics of DUI Offenders, Crash Victims, and the General Population in the Four Study Sites

\begin{tabular}{|c|c|c|c|c|c|c|c|c|}
\hline & \multicolumn{4}{|c|}{ Chester County, Pennsylvania } & \multicolumn{4}{|c|}{ Anne Arundel County, Maryland } \\
\hline & $\begin{array}{l}\text { First } \\
\text { Offenders }\end{array}$ & $\begin{array}{l}\text { Multtiple, } \\
\text { Offenders }\end{array}$ & Victims & $\begin{array}{c}\text { General } \\
\text { Population. }\end{array}$ & $\begin{array}{c}\text { First } \\
\text { Offenders }\end{array}$ & $\begin{array}{c}\text { Multiple } \\
\text { Offenders }\end{array}$ & Victims & $\begin{array}{c}\text { General } \\
\text { Population }\end{array}$ \\
\hline White (\%) & 93 & 90 & 90 & 92 & 87 & 79 & -- & 86 \\
\hline $\begin{array}{l}\text { College } \\
\text { Grads (\%) }\end{array}$ & 26 & 17 & 42. & 35 & 26 & 17 & - & 25 \\
\hline Male (\%) & 76 & 91 & 54 & 48 & 86 & 87 & -- & 50 \\
\hline Single (\%) & 54 & 38 & 38. & N/A & 45 & 54 & -- & N/A \\
\hline $\begin{array}{l}\text { Previously } \\
\text { Married (\%) }\end{array}$ & 13 & 27 & 8 & N/A & 32 & 30 & -- & N/A \\
\hline \multirow[t]{3}{*}{ Mean Age } & 33 & 38 & 37 & 34 & 36 & 35 & -- & 33 \\
\hline & \multicolumn{4}{|c|}{ Marin County, California } & \multicolumn{4}{|c|}{ New Castle County, Delaware } \\
\hline & $\begin{array}{c}\text { First } \\
\text { Offenders }\end{array}$ & $\begin{array}{c}\text { Multiple } \\
\text { Offenders }\end{array}$ & Victims & $\begin{array}{c}\text { General } \\
\text { Population }\end{array}$ & Offenders & $\begin{array}{l}\text { Muittiple } \\
\text { Offenders }\end{array}$ & Victims. & $\begin{array}{l}\text { General } \\
\text { Population }\end{array}$ \\
\hline White (\%) & 90 & 90 & 79 & 89 & 89 & 87 & 83 & 80 \\
\hline $\begin{array}{l}\text { College } \\
\text { Grads (\%) }\end{array}$ & 37 & 32 & 24 & 44 & 19 & 15 & 26 & 25 \\
\hline Male (\%) & 71 & 81 & 50 & 50 & 85 & 89 & 47 & 47 \\
\hline Single (\%) & 51 & 60 & 35 & N/A & 51 & 43 & 43 & N/A \\
\hline $\begin{array}{l}\text { Previously } \\
\text { Married (\%) }\end{array}$ & 24 & 28 & 6 & N/A & 16 & 21. & 10 & NIA \\
\hline Mean Age & 37 & 38 & 37 & 38 & 35 & 37 & 38 & 35 \\
\hline
\end{tabular}

The data indicate that DUI offenders are disproportionately male, living without families, less educated, and more working class, than either the victims or the general population. As mature men, they are very likely to be employed and to be susceptible to factors impinging on employment. Beyond this, it appears that the DUI offenders, especially the multiple offenders, are heavy drinkers in conjunction with driving. Not all 
drivers have an equal chance of being apprehended for drunk driving. Tables 3-2 and 3-3 and Figures 3-1 and 3-2 describe the frequency with which first offenders and multiple offenders consumed one to two or three drinks less than 1 hour before driving in the 12 months prior to their DUI arrest. (All question numbers refer to the DUI Offender Questionnaire in Appendix A.) It seems reasonable to think that many offenders were from groups of single and divorced working-class men where heavy drinking is accepted.

Table 3-2. Frequency of Consumption of One to Two Beers/Mixed Drinks/Glasses Wine Less Than 1 Hour Before Driving During the 12 Months Prior to DUI Arrest (Question 25)

\begin{tabular}{|l|r|r|r|r|r|r|}
\hline \multirow{2}{*}{ Frequency } & \multicolumn{2}{|c|}{ First Offenders } & \multicolumn{2}{c|}{ Multiple Offenders } & \multicolumn{2}{|c|}{ Total } \\
\cline { 2 - 7 } & Number & Percent & Number & Percent & Number & Percent \\
\hline Never & 27 & 4.7 & 9 & 3.9 & 36 & 4.5 \\
\hline Once in a while & 381 & 66.5 & 106 & 45.9 & 487 & 60.6 \\
\hline More than once per & 139 & 24.3 & 86 & 37.2 & 225 & 28.0 \\
week & & & & & & \\
\hline Daily & 26 & 4.5 & 30 & 13.0 & 56 & 7.0 \\
\hline Total & 573 & 100.0 & 231 & 100.0 & 804 & 100.0 \\
\hline
\end{tabular}

Figure 3-1. Frequency of Consumption of One to Two Beers/Mixed Drinks/Glasses Wine Less Than 1 Hour Before Driving During the 12 Months Prior to DUI Arrest

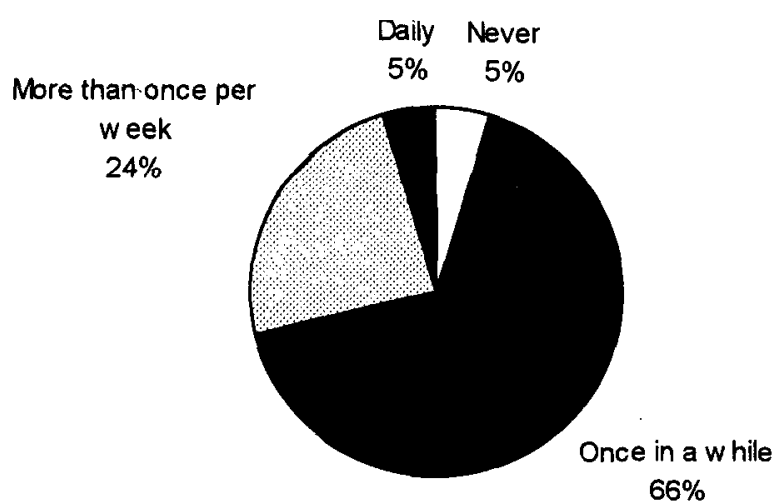

First Offenders

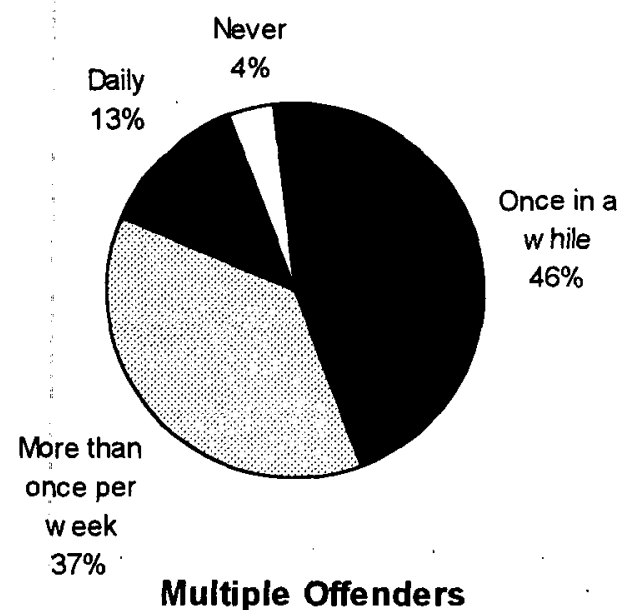

Multiple Offenders 
Table 3-3. Frequency of Consumption of Three Beers/Mixed Drinks/Glasses Wine Less Than 1 Hour Before Driving During the 12 Months Prior to DUI Arrest

(Question 26)

\begin{tabular}{|c|c|c|c|c|c|c|}
\hline \multirow[b]{2}{*}{ Frequency } & \multicolumn{2}{|c|}{ First Offenders } & \multicolumn{2}{|c|}{ Multiple Offenders } & \multicolumn{2}{|c|}{ Total } \\
\hline & Number & Percent & Number & Percent & Number & Percent \\
\hline Never & 117 & 20.6 & 32. & $14: 0$ & 149 & 18.7 \\
\hline Once in a while & 349 & 61.4 & 113 & 49.3 & 462 & 58.0 \\
\hline $\begin{array}{l}\text { More than once per } \\
\text { week }\end{array}$ & 83 & 14.6 & 65 & 28.4 & 148 & 18.6 \\
\hline Daily & 19 & 3.3 & 19 & $\overline{8.3}$ & 38 & 4.8 \\
\hline Total & 568 & 1000 & 229 & 100.0 & 797 & 100.0 \\
\hline
\end{tabular}

Figure 3-2. Frequency of Consumption of Three Beers/Mixed Drinks/Glasses Wine Less Than 1 Hour Before Driving During the 12 Months Prior to DUI Arrest

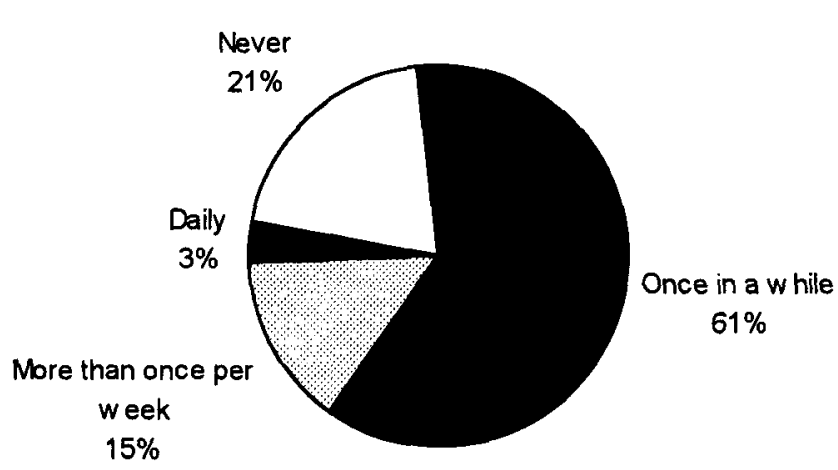

First Offenders

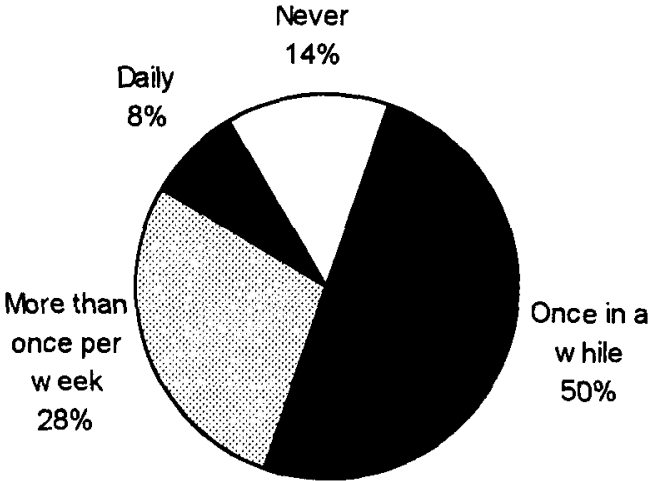

Multiple Offenders

It is important to know in what ways the DUIs are not atypical. They are not importantly different from the victims (or the general public) in average age and in racial composition.

The victim populations were socio-demographically close to the general population, a finding that might be expected in an auto-dependent society if victimization merely depends on using the public roads. One can picture victimization 
in the sense used here, excluding impaired drivers, as the consequence of something like a random draw from the general population or the population of road users.

\subsection{Impact on Jobs}

This central question was examined in numerous ways for both DUI offenders and crash victims. The following analyses were performed for DUI offenders:

1. The DUI offenders were asked to rate the extent that their loss of license has interfered with work (for those DUI offenders who were working at the time of the DUI arrest).

2. The DUI offenders were asked to report income for the jobs they held from 1992-1994. An impact analysis was performed for first and multiple offenders which compared the change in income after DUI arrest for DUI offenders in each of the ALR states to the change in income after DUI arrest for DUI offenders in the non-ALR comparison state.

3. The DUI offenders were asked how much income they lost per week as a direct result of their DUI arrest/loss of license. The percent reduction in income from the income reported for the month of the DUI arrest was computed for all DUI offenders (where available). A t-test of difference between the percent reduction in each of the three ALR states and the percent reduction in the comparison non-ALR state was performed for both first and multiple offenders to determine whether the percent reduction was significantly greater in the ALR states.

4. The DUI offenders were asked to describe the effect of their most recent DUI arrest on their employment. These open-ended responses were coded into categories and summarized.

5. The activity the month after DUI arrest was examined for those DUI offenders who were working the month before their arrest to determine whether changes in employment were more pronounced in ALR states when compared to the non-ALR state.

6. A regression analysis was performed to predict income based on multiple explanatory variables to determine whether there was a strong relationship between income and ALR status.

The following additional analyses were performed for DUI crash victims: 
1. The crash victims were asked to describe the effect of the DUI crash on their employment. These open-ended responses were coded into categories and summarized.

2. The crash victims were asked how much income they lost per week as a direct result of their DUI crash. The percent reduction in income from the income reported for the month of the DUI crash was computed for all DUI crash victims (where available). A t-test of difference between the percent reduction for DUI offenders and the percent reduction for DUI crash victims was performed to determine whether the percent reduction was significantly greater for crash victims or DUI offenders.

3. The activity the month after the DUI crash was examined for those crash victims who were working the month before their crash to determine whether changes in employment were more pronounced for crash victims when compared to DUI offenders.

The results of the above analyses are presented in the following two subsections for DUI offenders and DUI crash victims.

\section{Impact on DUI Offenders}

Table 3-4 and Figure 3-3 present the offenders' evaluation of the impact of the DUI arrest and loss of license on their jobs. Nearly half the offenders reported that the experience greatly interfered with their work. It can be seen from Table 3-5 that these were disproportionately people who claimed that their jobs required the use of a car, whether for commuting or even more so for those using a car in their work. Multiple offenders were in general more likely to report a great extent of interference than were first offenders, as might be expected given the heavier license penalties reported by this group. There does not seem to be an orderly pattern of responses among the states and therefore among different kinds and lengths of ALR. 
Table 3-4. Extent Loss of License Has Interfered With Work (Question 39a)

\begin{tabular}{|l|r|r|r|r|r|r|}
\hline \multirow{2}{*}{ Extent } & \multicolumn{2}{|c|}{ First Offenders } & \multicolumn{2}{c|}{ Multiple Offenders } & \multicolumn{2}{c|}{ Total } \\
\cline { 2 - 7 } & Number & Percent & Number & Percent & Number & Percent \\
\hline Not applicable & 32 & 7.9 & 13 & 7.2 & 45 & 77 \\
\hline Not at all & 109 & 27.0 & 42 & 23.2 & 151 & 25.9 \\
\hline To a little extent & 29 & 7.2 & 12 & 6.6 & 41 & 7.0 \\
\hline To some extent & 64 & 15.9 & 30 & 16.6 & 94 & 16.1 \\
\hline To a great extent & 169 & 41.9 & 84 & 46.4 & 253 & 43.3 \\
\hline Total & 403 & 100.0 & 181 & 100.0 & 584 & 100.0 \\
\hline
\end{tabular}

Figure 3-3. License Loss Effect on Work
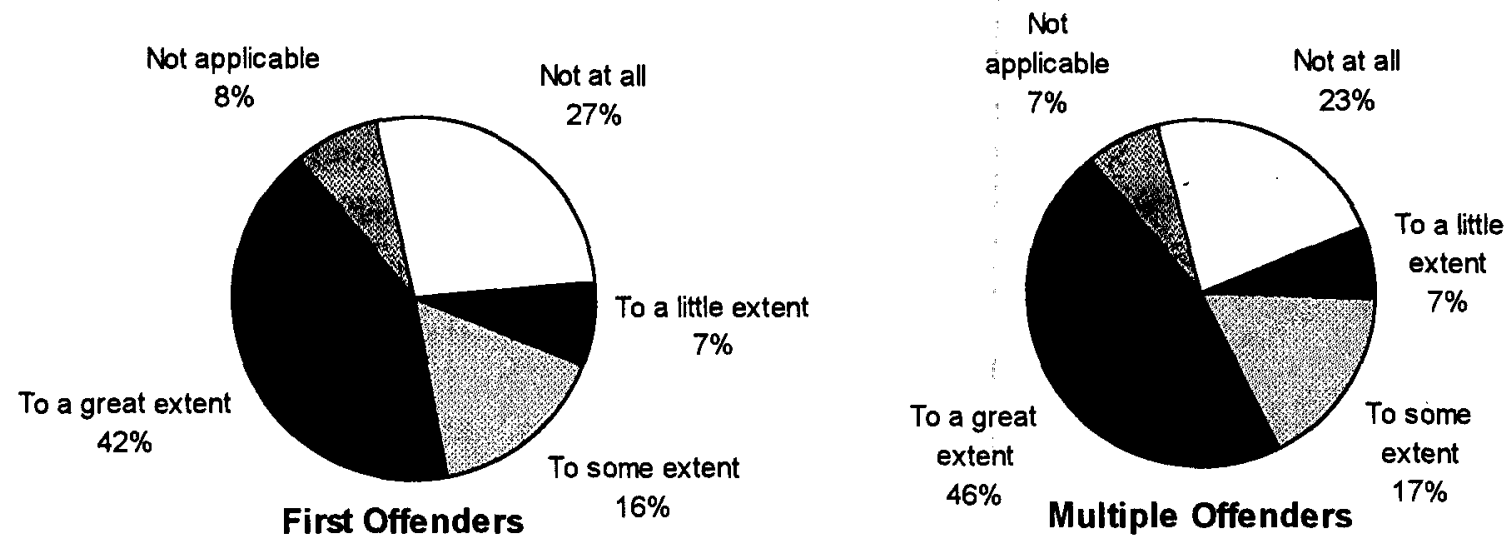
Table 3-5. Extent Loss of License Has Interfered With Work by Need for Vehicle/License (Question 39a)

\begin{tabular}{|c|c|c|c|c|c|c|c|c|}
\hline \multirow[b]{2}{*}{ Extent } & \multicolumn{2}{|c|}{$\begin{array}{c}\text { Need } \\
\text { Car/License to } \\
\text { Perform Job }\end{array}$} & \multicolumn{2}{|c|}{$\begin{array}{l}\text { Need Car to } \\
\text { Commute Only }\end{array}$} & \multicolumn{2}{|c|}{$\begin{array}{c}\text { No Need for Car } \\
\text { or No } \\
\text { Employment }\end{array}$} & \multicolumn{2}{|c|}{ Total } \\
\hline & Number & Percent & Number & Percent & Number & Percent & Number & Percent \\
\hline Not applicable & 12 & 4.1 & 8. & 6.3 & 24 & 170 & 44 & 78 \\
\hline Not at all & 53 & 18.1 & 36 & 28.3 & 59 & 41.8 & 148 & 26.4 \\
\hline To a litue extent & 15 & 51 & 10 & 79 & 12 & 8.5 & 37 . & 66 \\
\hline To some extent & 44 & 15.0 & 28 & 22.0 & 14 & 9.9 & 86 & 15.3 \\
\hline Toxtent great & 169 & 577 & 45 & 35.4 & 32 & 227 & 246 & 43.9 \\
\hline Total & 293 & 100.0 & 127 & 100.0 & 141 & 100.0 & 561 & 100.0 \\
\hline
\end{tabular}

Similar proportions of respondents claimed interference with activities other than work, such as shopping, attending church, and visiting the doctor. The highest proportions were with respect to social and recreational activities, where great interference was reported by at least half of the respondents in all states, first offenders as well as repeat offenders.

Relatively few people--fewer than 10 percent--reported having changed jobs at about the time of the DUI arrest. Of these, however, close to half attributed leaving to the DUI arrest. This was true for 32 percent of first offenders and 62 percent of the multiple offenders who had changed jobs. The numbers of job changers were insufficient to perform a valid analysis by state.

However, the above claims of interference with jobs were not supported in other data. The offenders were asked to report the beginning and end employment dates and average income for all jobs they held in 1992, 1993, and 1994. From this job history, the average monthly income was computed for each month in these 3 years for each DUI offender. Changes in income due to the DUI arrest were measured separately for first and multiple offenders in a monthly impact analysis (described in Appendix F) and are reported in Tables 3-6 and 3-7, respectively. The impact analysis regression model controlled for the effect of the DUI offender being in jail or attending school in any given month as well as the expected increase in monthly income over time. Monthly impact measures/significance levels were obtained for the 6 months after DUI arrest for three separate models (for both first and multiple offenders): Maryland versus Pennsylvania, California versus Pennsylvania, and Delaware versus Pennsylvania. Those impact measures that were significant at the $5 \%$ level are indicated with an asterisk in Tables 3-6 and 3-7. 
The impact measure of "minus $\$ 27$ " for the first month after DUl arrest for the Maryland vs. Pennsylvania first offender model in Table 3-6 is interpreted to mean that Maryland first offenders made $\$ 27$ less in the first month after their DUI arrest when compared to Pennsylvania first offenders in their first month after DUI arrest. Although this difference is in the direction expected by the hypothesis, the impact was not significant at the $5 \%$ level. In other words, this difference could occur by chance more than 5 percent of the time.

It is theorized that an effect on employment for first and multiple offenders, if any, should be evident in the first 3 months following the arrest. The following presents an analysis for each of the three ALR states when compared with the non-ALR state (Pennsylvania). Figures 3-4 and 3-5 illustrate this data in chart form.

For first offenders, the earnings comparison between Delaware and Pennsylvania was not significant, though in the same direction as that presented in the hypothesis (income was reduced more in the ALR state when compared to the nonALR state). There was no significant impact on earnings for multiple offenders, and the differences were in the opposite direction from that presented in the hypothesis (postarrest income was higher in the ALR state than in the non-ALR state).

The same patterns and lack of significance were found when offenders in Maryland were compared with those in Pennsylvania. The impact analysis for California first offenders showed a significant gain against Pennsylvania in earnings. No significant effect was noted for California multiple offenders in the first several months after arrest. 


\section{Table 3-6. First Offender Income Impact After DUI Arrest}

The impact on employment of first offenders in each of the three ALR states (Maryland, California, and Delaware) was compared to the impact on employment of first offenders in the non-ALR comparison state (Pennsylvania) for each of the 6 months after DUI arrest. The value of (\$27) for Maryland versus Pennsylvania first offenders means that these Maryland first offenders made \$27 less in the first month after arrest when compared to Pennsylvania first offenders. It should be noted that many offenders in the ALR states may have had a temporary license during the first month after arrest.

\begin{tabular}{|c|c|c|c|c|c|c|}
\hline & $\begin{array}{c}\text { 1st Month } \\
\text { After } \\
\text { Arrest }\end{array}$ & $\begin{array}{c}\text { 2nd Month } \\
\text { After } \\
\text { Arrest }\end{array}$ & $\begin{array}{l}\text { 3rd Month } \\
\text { After Arrest }\end{array}$ & $\begin{array}{c}\text { 4th Month } \\
\text { After } \\
\text { Arrest } \\
\end{array}$ & $\begin{array}{c}\text { 5th Month } \\
\text { After } \\
\text { Arrest }\end{array}$ & $\begin{array}{c}\text { 6th Month } \\
\text { After } \\
\text { Arrest }\end{array}$ \\
\hline $\begin{array}{l}\text { Movs.PA } \\
\text { First } \\
\text { Orfenders }\end{array}$ & $(\$ 27)$ & $\$ 9$ & $(\$ 103)^{*}$ & $(61)$ & $(\$ 9)$ & $\$ 13$ \\
\hline $\begin{array}{l}\text { CA vs. PA } \\
\text { First } \\
\text { Offenders }\end{array}$ & $\$ 241^{\star}$ & $\$ 272^{\star}$ & $\$ 250^{\star}$ & $\$ 114$ & $\$ 177$ & $\$ 69$ \\
\hline $\begin{array}{l}\text { DE VS PA } \\
\text { First } \\
\text { Orfenders: }\end{array}$ & $(\$ 22)$ & $(\$ 32)$ & $(\$ 16)$ & (\$3) & $(\$ 109)^{*}$ & $(\$ 134)^{*}$ \\
\hline
\end{tabular}

* Impact significant at $5 \%$ level (could occur by chance less than $5 \%$ of the time).

Figure 3-4. Impact Analysis of ALR on First Offender Income

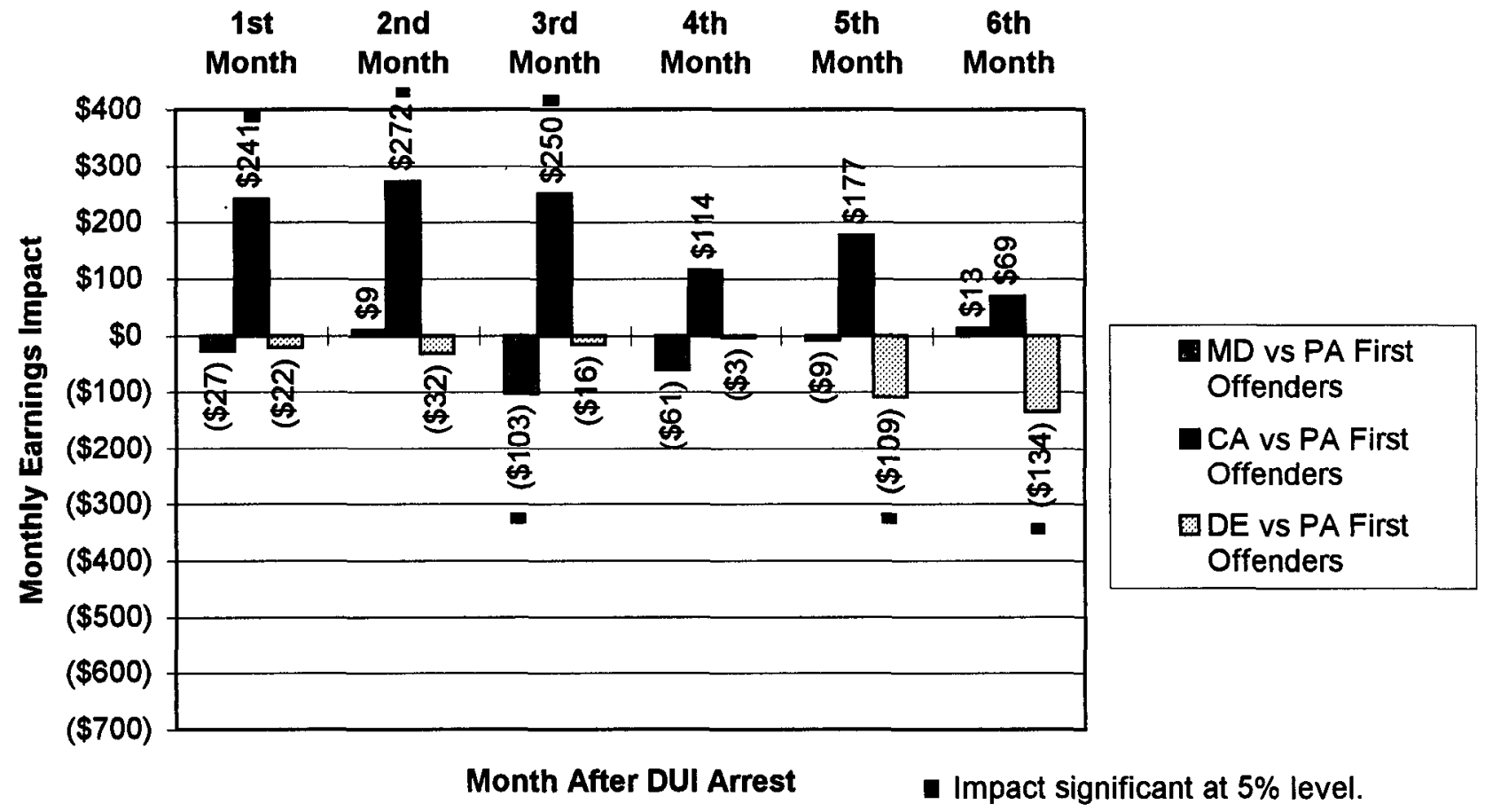




\section{Table 3-7. Multiple Offender Income Impact After DUI Arrest}

The impact on employment of multiple offenders in each of the three ALR states (Maryland, California, and Delaware) was compared to the impact on employment of multiple offenders in the non-ALR comparison state (Pennsylvania) for each of the 6 months after DUI arrest. The value of $\$ 54$ for Maryland versus Pennsylvania multiple offenders means that these Maryland multiple offenders made $\$ 54$ more in the first month after arrest when compared to Pennsylvania multiple offenders. It should be noted that many offenders in the ALR states may have had a temporary license during the first month after arrest.

\begin{tabular}{|c|c|c|c|c|c|c|}
\hline & $\begin{array}{l}\text { 1st Month } \\
\text { After } \\
\text { Arrest }\end{array}$ & $\begin{array}{l}\text { 2nd Month } \\
\text { After Arrest }\end{array}$ & $\begin{array}{l}\text { 3rd Month } \\
\text { After Arrest }\end{array}$ & $\begin{array}{l}\text { 4th Month } \\
\text { After Arrest }\end{array}$ & $\begin{array}{l}\text { 5th Month } \\
\text { After } \\
\text { Arrest } \\
\end{array}$ & $\begin{array}{c}\text { 6th Month } \\
\text { After } \\
\text { Arrest } \\
\end{array}$ \\
\hline $\begin{array}{l}\text { MO vs.PA } \\
\text { Multiple } \\
\text { Offenders }\end{array}$ & $\$ 54$ & $(\$ 195)$ & $(\$ 150)$ & $(\$ 235)^{\prime}$ & $(\$ 434)^{t}$ & $(\$ 450)^{*}$ \\
\hline $\begin{array}{l}\text { CA vs. PA } \\
\text { Multiple } \\
\text { Offenders }\end{array}$ & $\$ 154$ & (\$43) & $(\$ 428)^{*}$ & $(\$ 422)^{*}$ & $(\$ 510)^{\star}$ & (\$201) \\
\hline $\begin{array}{l}\text { DE vS. PA. } \\
\text { Multiple. } \\
\text { Offenders }\end{array}$ & $\$ 134$ & $\$ 57$ & $\$ 22$ & $\$ 11$ & $(\$ 44)$ & $(\$ 18)$ \\
\hline
\end{tabular}

* Impact significant at $5 \%$ level (could occur by chance less than $5 \%$ of the time).

Figure 3-5. Impact Analysis of ALR on Multiple Offender Income

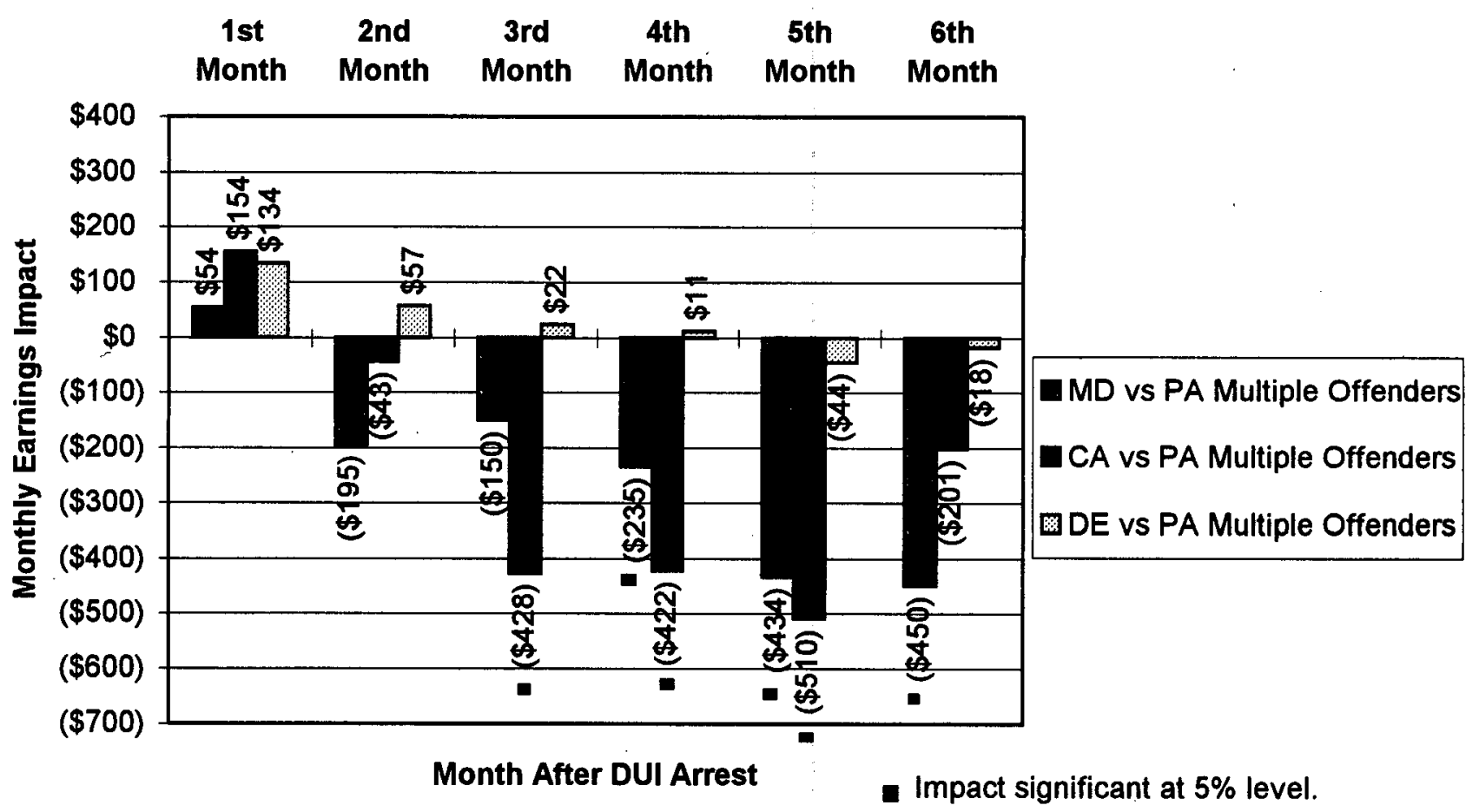


The offenders were asked how much income they lost per week as a direct result of their DUI arrest/loss of license. The percent reduction in income from the income reported for the month of the DUI arrest was computed for all offenders (where available). A t-test of difference between the percent income reduction in each of the three ALR states and the percent income reduction in the comparison non-ALR state was performed for both first and multiple offenders and is reported in Table 3-8. Since none of these six tests was significant at the $5 \%$ level (significance probability less than 0.05 ), there was no significant difference in the percent reduction in income resulting from the DUI arrest between ALR and non-ALR states for either first or multiple offenders. It was assumed that the offenders in ALR and non-ALR states experienced similar criminal sanctions. However, these sanctions probably took place after the period of ALR impact evaluation.

Table 3-8. Difference in Percent Reduction in Income Between ALR and Non-ALR States

\begin{tabular}{|c|c|c|c|c|}
\hline $\begin{array}{c}\text { Group 1 } \\
\text { Description }\end{array}$ & $\begin{array}{l}\text { Group } 1 \\
\% \text { Reduction } \\
\text { in Income }\end{array}$ & $\begin{array}{c}\text { Group } 2 \\
\text { Description }\end{array}$ & $\begin{array}{c}\text { Group } 2 \\
\% \text { Reduction } \\
\text { in Income }\end{array}$ & $\begin{array}{c}\text { Significance } \\
\text { Probability }\end{array}$ \\
\hline PA first offenders. & $10.5 \%$ & MD first offenders & $7.4 \%$ & 2945 \\
\hline PA first offenders & $10.5 \%$ & CA first offenders & $14.6 \%$ & 1543 \\
\hline PA first offenders. & $10.5 \%$ & DE first offenders. & $8.2 \%$ & 3609 \\
\hline $\begin{array}{l}\text { PA multiple } \\
\text { offenders }\end{array}$ & $11.8 \%$ & $\begin{array}{l}\text { MD multiple } \\
\text { offenders }\end{array}$ & $12.0 \%$ & .9707 \\
\hline $\begin{array}{l}\text { PA multiple } \\
\text { offenders }\end{array}$ & $11.8 \%$ & $\begin{array}{l}\text { CA multiple } \\
\text { offenders }\end{array}$ & $19.4 \%$ & 1595 \\
\hline $\begin{array}{l}\text { PA multiple } \\
\text { offenders }\end{array}$ & $11.8 \%$ & $\begin{array}{l}\text { DE multiple } \\
\text { offenders }\end{array}$ & $14.3 \%$ & 6409 \\
\hline
\end{tabular}

The offenders were asked to describe the effect of their recent arrest on their employment and income. All open-ended responses were categorized as shown in Table 3-9 and Figure 3-6. Over 55 percent of the respondents stated there was no change in their employment or income after the DUI arrest. 
Table 3-9. Stated Changes in Employment and Income as a Result of the DUI Arrest (Question 10)

\begin{tabular}{|l|r|r|r|r|r|r|}
\hline \multirow{2}{*}{$\begin{array}{c}\text { Effect on } \\
\text { Employment }\end{array}$} & \multicolumn{2}{|c|}{ First Offenders } & \multicolumn{2}{c|}{ Multiple Offenders } & \multicolumn{2}{c|}{ Total } \\
\cline { 2 - 7 } & Number & Percent & Number & Percent & Number & Percent \\
\hline No change & 394 & 60.0 & 125 & 45.6 & 519 & 55.8 \\
\hline Job change & 64 & 9.7 & 53 & 19.4 & 117 & 12.6 \\
\hline Lost time & 48 & 7.3 & 25 & 9.1 & 73 & 78 \\
\hline Lost income & 98 & 14.9 & 50 & 18.2 & 148 & 15.9 \\
\hline $\begin{array}{l}\text { Miscellaneous } \\
\text { expenses }\end{array}$ & 53 & 8.1 & 21 & 7.7 & 74 & 7.9 \\
\hline Total & & & & & & \\
\hline
\end{tabular}

Figure 3-6. DUI Arrest Effect on Employment and Income

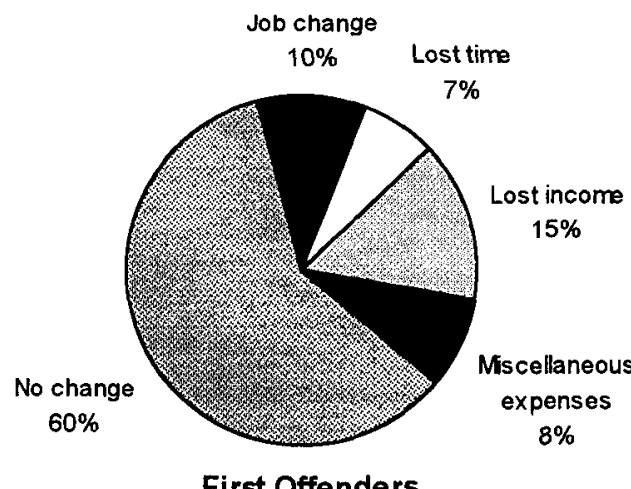

First Offenders

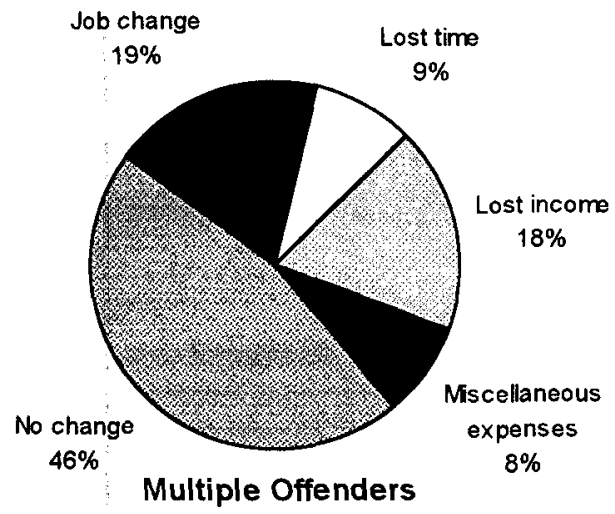

Multiple Offenders

Another measure of the impact of ALR on employment is the change in the offender's activity from the month right before arrest to the month right after arrest for those who were working in the month before arrest. Table 3-10 shows this transition for the non-ALR state, the ALR states, and total. The percent still working the month after arrest (94 percent) was identical for DUI offenders in the three ALR states and the non-ALR state. However, many offenders in the ALR states may have had a temporary license during the first month after arrest. Attending school may well have been independent of arrest. 
Table 3-10. Activity the Month After DUI Arrest for

Those Working the Month Before Arrest (Question 9)

\begin{tabular}{|c|c|c|c|c|c|c|c|c|c|}
\hline & \multicolumn{8}{|c|}{ Activity the Month After Arrest } & \multirow{3}{*}{$\begin{array}{c}\text { Total } \\
\text { Working } \\
\text { Month Before } \\
\text { Arrest }\end{array}$} \\
\hline & \multicolumn{2}{|c|}{ Working } & \multicolumn{2}{|c|}{$\begin{array}{l}\text { Attending } \\
\text { School }\end{array}$} & \multicolumn{2}{|c|}{ Unemployed } & \multicolumn{2}{|c|}{ Other } & \\
\hline & No. & $\%$ & No. & $\%$ & No. & $\%$ & No. & $\%$ & \\
\hline $\begin{array}{l}\text { DUl offenders } \\
\text { in non-ALR } \\
\text { state working } \\
\text { the month } \\
\text { before arrest }\end{array}$ & 175 & 94 & 4 & 2 & 8 & 4 & 3 & 1 & 190 \\
\hline $\begin{array}{l}\text { DUI offenders } \\
\text { in ALR states } \\
\text { working the } \\
\text { month before } \\
\text { arrest }\end{array}$ & 472 & 94 & 5 & 1 & 20 & 4 & 3 & 1 & 500 \\
\hline $\begin{array}{l}\text { All DUI } \\
\text { offenders } \\
\text { working the } \\
\text { month before } \\
\text { arrest }\end{array}$ & 647. & 94 & 9 & 1 & 28 & 4 & 6 & 1 & 690 \\
\hline
\end{tabular}

Finally, a regression analysis, performed to predict income based on an array of explanatory variables, found strong significant relationships with gender, marital status, age, and education, but not with the state of residence (and therefore, probably not with ALR status).

In brief, expectations that earnings of offenders in ALR states should be disproportionately reduced were not supported by most of the above analyses.

\section{Impact on DUI Crash Victims}

Membership in the victim group was defined in terms of unimpaired survivors of alcohol-related crashes. Even though this analysis compared people who were in crashes with a broader group of DUls, most of whom were not, the evidence does not support the idea that the employment of victims is more impacted than that of the DUI offenders. Victims seldom reported a disability-related change in jobs-only 6 of 146 made this claim, and it is not necessarily the case that the disability was related to the victimization.

When the crash victims were asked to describe the impact on their employment that resulted from involvement in the alcohol-related crash, over 56 percent reported no impact. It is important to note that assuming self-selection bias, the more seriously injured/impacted 
crash victims may have been more likely to return the questionnaire. The open-ended responses were coded as shown in Table 3-11 and Figure 3-7.

Table 3-11. Stated Changes in Employment and Income as a Result of DUI Crash (Question 5)

\begin{tabular}{|l|c|c|}
\hline \multicolumn{1}{|c|}{ Effect on Employment } & Number Crash Victims & Percent \\
\hline No impact & 82 & 56.2 \\
\hline Job activities have been limited & 7 & 4.8 \\
\hline Lost from 1 day to 2 weeks pay & 22 & 15.0 \\
\hline $\begin{array}{l}\text { Could not work from 2 weeks to } 6 \\
\text { months }\end{array}$ & 21 & 14.4 \\
\hline $\begin{array}{l}\text { Currenty unemployed due to iniury } \\
\text { Total }\end{array}$ & 14 & 9.6 \\
\hline
\end{tabular}

Figure 3-7. DUI Crash Victim Employment and Income Changes

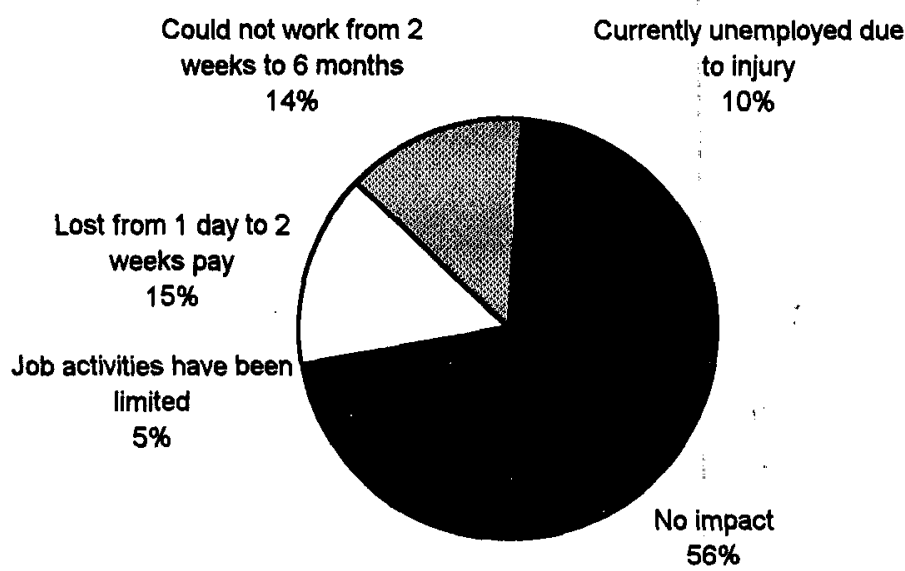

Victims 
The crash victims were asked how much income they lost per week as a direct result of their DUI crash. The percent reduction in income from the income reported for the month of the DUI crash was computed for all DUI crash victims (where available). A t-test of difference between the percent reduction for DUI offenders and the percent reduction for DUI crash victims was performed. The percent reduction was actually greater for offenders (12.0 percent) compared to DUl crash victims (7.6 percent). However, with a significance probability of 0.0646 , this difference failed to be significant at the $5 \%$ level.

Another measure of the impact of the crash on employment is the change in the crash victim's activity from the month right before the crash to the month right after the crash for those who were working in the month before the crash. Table 3-12 shows this transition for the three states and total. The percent still working the month after the crash was less for the victims ( 71 percent total) compared to the offenders ( 94 percent total).

\subsection{Driving While Revoked}

Although the respondents frequently claimed interference with work from the DUI and license revocation, many of them admitted to driving to work and for other social functions. Data are presented in Tables 3-13 and 3-14 and Figures 3-8 and 3-9 for those DUI offenders who lost their license. Particularly in the ALR states, large numbers of informants rated the probability that they would drive without a license as very likely, reaching nearly two-thirds for California multiple offenders.

Important numbers of DUI offenders who lost their license stated that they drive to work. The figure was higher in Maryland and California, where hardship licenses are available, but even in Delaware a fifth of first offenders and one in seven multiple offenders declared that they continue to drive to work. Taxis and public transportation were an important alternative only in California, where experience suggests that these might be more viable options. However, the main alternative in general was driving with others, perhaps relatives or neighbors. Driving with others was the most frequent form of transportation everywhere for shopping, church attendance, and especially social and recreational activities. A majority of respondents in all circumstances lived in households where there was at least one other licensed driver, who might be able to provide this service. 
Table 3-12. Activity the Month After DUI Crash for Those Working the Month Before Crash (Question 6)

\begin{tabular}{|c|c|c|c|c|c|c|c|c|c|}
\hline & \multicolumn{8}{|c|}{ Activity the Month After Crash } & \multirow{3}{*}{$\begin{array}{c}\text { Total } \\
\text { Working } \\
\text { Month Before } \\
\text { Crash }\end{array}$} \\
\hline & \multicolumn{2}{|c|}{ Working } & \multicolumn{2}{|c|}{$\begin{array}{l}\text { Attending } \\
\text { School }\end{array}$} & \multicolumn{2}{|c|}{ Unemployed } & \multicolumn{2}{|c|}{ Disabled } & \\
\hline & No. & $\%$ & No. & $\%$ & No. & $\%$ & No. & $\%$ & \\
\hline $\begin{array}{l}\text { DUI crash } \\
\text { victims in PA } \\
\text { working the } \\
\text { month before } \\
\text { crash }\end{array}$ & 37 & 79 & 1 & 2 & 2 & 4 & 7 & 15 & 47 \\
\hline $\begin{array}{l}\text { DUI crash } \\
\text { victims in CA } \\
\text { working the } \\
\text { month before } \\
\text { crash }\end{array}$ & 14 & 56 & 0 & 0 & 1 & 4 & 10 & 40 & 25 \\
\hline $\begin{array}{l}\text { DUl crash } \\
\text { victims in DE } \\
\text { working the } \\
\text { month before } \\
\text { crash }\end{array}$ & 27 & 71 & 3 & 8 & 0 & 0 & 8 & 21 & 38 \\
\hline $\begin{array}{l}\text { All DUl crash } \\
\text { victims } \\
\text { working the } \\
\text { month before } \\
\text { crash }\end{array}$ & 78 & 71 & 4 & 4 & 3 & 2 & 25 & 23 & 110 \\
\hline
\end{tabular}


Table 3-13. DUI Offender's Likelihood of Driving Without a License (Question 37)

\begin{tabular}{|l|r|r|r|r|r|r|}
\hline \multirow{2}{*}{ Likelihood } & \multicolumn{2}{|c|}{ First Offenders } & \multicolumn{2}{c|}{ Multiple Offenders } & \multicolumn{2}{c|}{ Total } \\
\cline { 2 - 7 } & Number & Percent & Number & Percent & Number & Percent \\
\hline Not at all likely & 266 & 55.6 & 89 & 43.2 & 355 & 51.9 \\
\hline Unlikely & 41 & 8.6 & 22 & 10.7 & 63 & 9.2 \\
\hline Somewhat likely & 30 & 6.3 & 14 & 6.8 & 44 & 6.4 \\
\hline Very likely & 141 & 29.5 & 81 & 39.3 & 222 & 32.5 \\
\hline Total & 478 & 100.0 & 206 & 100.0 & 684 & 100.0 \\
\hline
\end{tabular}

Figure 3-8. Likelihood of Driving Without a License

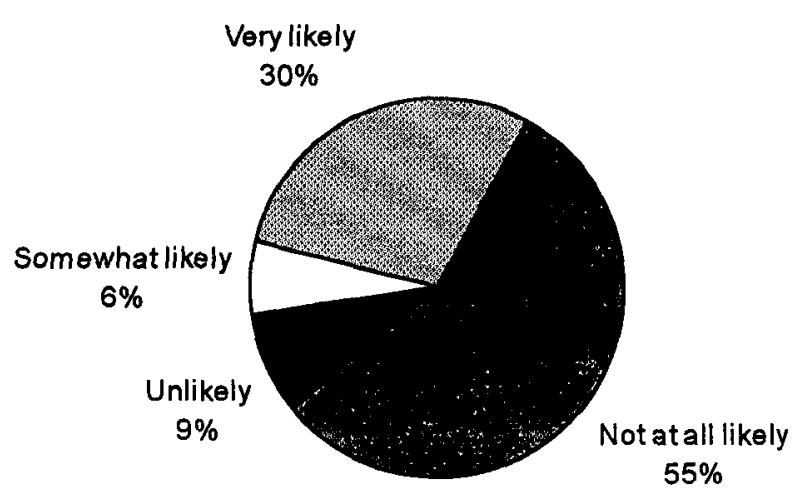

First Offenders

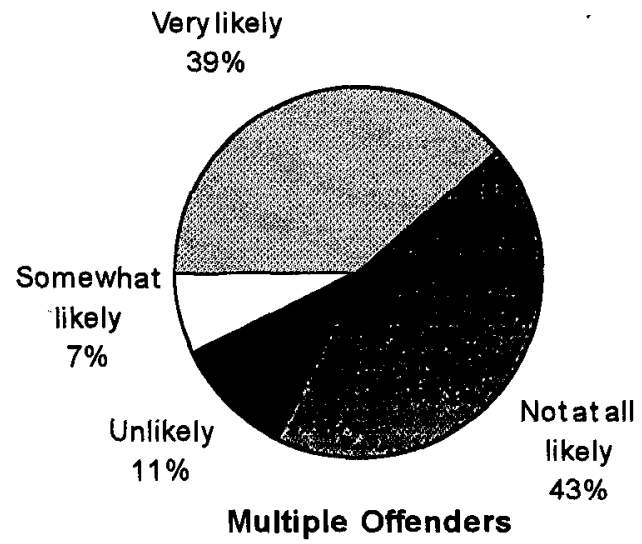


Table 3-14. DUI Offender's Transportation Arrangements for Work While Waiting for License Reinstatement (Question 40a)

\begin{tabular}{|l|r|r|r|r|r|r|}
\hline \multirow{2}{*}{ Arrangement } & \multicolumn{2}{|c|}{ First Offenders } & \multicolumn{2}{c|}{ Multiple Offenders } & \multicolumn{2}{c|}{ Total } \\
\cline { 2 - 8 } & Number & Percent & Number & Percent & Number & Percent \\
\hline Drive myself & 110 & 21.5 & 52 & 22.3 & 162 & 21.1 \\
\hline $\begin{array}{l}\text { Someone else } \\
\text { drives me }\end{array}$ & 226 & 44.1 & 95 & 40.9 & 321 & 43.2 \\
\hline $\begin{array}{l}\text { Taxi or public } \\
\text { transportation }\end{array}$ & 78 & 15.2 & 36 & 15.5 & 14. & 15.3 \\
\hline Walk or bicycle & 69 & 13.5 & 34 & 14.6 & 103 & 13.8 \\
\hline Other/not applicable & 29 & 5.7 & 16 & 6.9 & 45 & 6.0 \\
\hline Total & 512 & 100.0 & 233 & 100.0 & 745 & 100.0 \\
\hline
\end{tabular}

Figure 3-9. Transportation Arrangement for DUI Offender
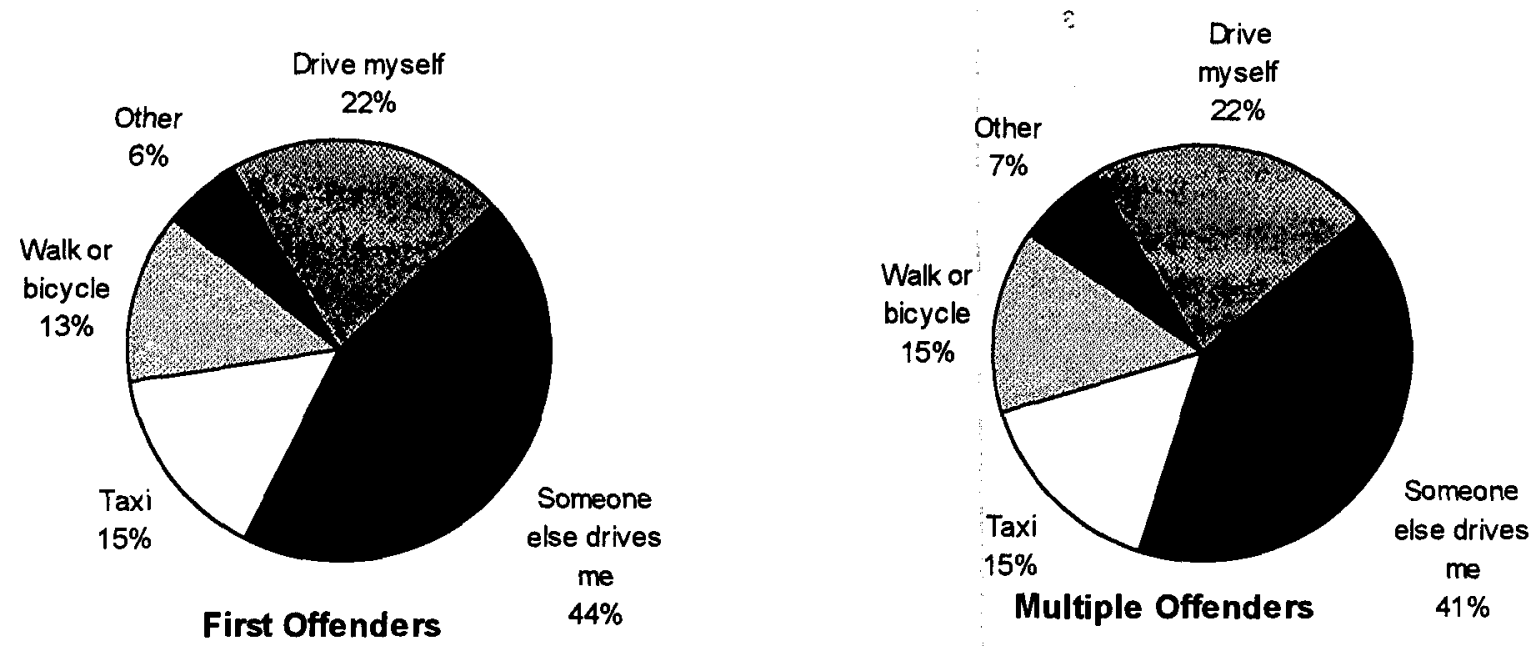

In Table 3-15 and Figure 3-10, it can be seen that more than a third of respondents who lost their license reported that they drove on the most recent day they worked. Maryland and California had the highest proportions, which reached a majority for California multiple offenders. Even in Delaware, which does not issue hardship licenses, important proportions drove, though fewer than in the other states. 
Table 3-15. Method of Transportation for DUI Offender's Most Recent Day of Work (Question 40g)

\begin{tabular}{|l|r|r|r|r|r|r|}
\hline \multirow{2}{*}{$\begin{array}{c}\text { Method of } \\
\text { Transportation }\end{array}$} & \multicolumn{2}{|c|}{ First Offenders } & \multicolumn{2}{c|}{ Multiple Offenders } & \multicolumn{2}{c|}{ Total } \\
\cline { 2 - 7 } & Number & Percent & Number & Percent & Number & Percent \\
\hline Drove myself & 162 & 38.8 & 66 & 36.1 & 228 & 38.0 \\
\hline $\begin{array}{l}\text { Someone else } \\
\text { drove me }\end{array}$ & 162 & 38.8 & 70 & 38.3 & 232 & 38.7 \\
\hline $\begin{array}{l}\text { Taxi or public } \\
\text { transportation }\end{array}$ & 36 & 86 & 16 & 87 & 52 & 8.7 \\
\hline Walk or bicycle & 38 & 9.2 & 20 & 10.9 & 58 & 7.6 \\
\hline Other/not applicable & 19 & 4.6 & 11 & 6.0 & 30 & 5.0 \\
\hline Total & 417 & 100.0 & 183 & 100.0 & 600 & 100.0 \\
\hline
\end{tabular}

Figure 3-10. Most Recent Work Day Transportation
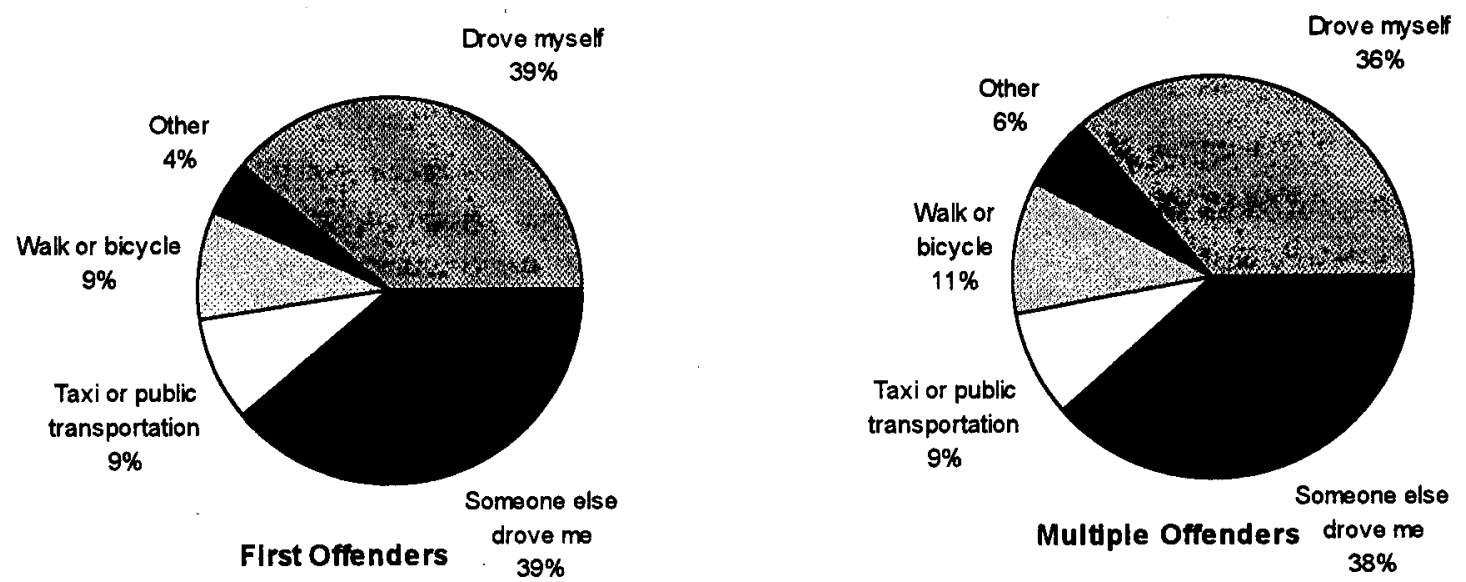

These declarations are supported by reports of having driven to the educational or therapy program. This was most common in California and Maryland, where it may be related to the availability of hardship licenses. Again, public transportation was seldom used and the major alternative to driving one's self was to travel with someone else.

When all occasions for travel are considered for those DUI offenders without a license, 46 percent admitted that they drove (48 percent of first offenders and 41 percent of multiple offenders). Driving without a license was most common in California (65 percent overall) and least common in Delaware (30 percent overall). 
Driving while unlicensed is likely to be encouraged by the belief that there is little danger of being caught. As can be seen in Table 3-16 and Figure 3-11, majorities of both first and multiple offenders rated the risk as low, and only seven percent of the sample said that being caught is very likely during a month of unlicensed driving.

Table 3-16. Likelihood of Being Caught for Those DUI Offenders Who Drive Without a License (Question 38)

\begin{tabular}{|l|r|r|r|r|r|r|}
\hline \multirow{2}{*}{$\begin{array}{l}\text { Likelihood of } \\
\text { Being Caught }\end{array}$} & \multicolumn{2}{|c|}{ First Offenders } & \multicolumn{2}{c|}{ Multiple Offenders } & \multicolumn{2}{c|}{ Total } \\
\cline { 2 - 7 } & Number & Percent & Number & Percent & Number & Percent \\
\hline Not at all likely & 105 & 53.3 & 59 & 56.7 & 164 & $54: 5$ \\
\hline Unlikely & 44 & 22.3 & 20 & 19.2 & 64 & 21.3 \\
\hline Somewhat likely & 34 & 17.3 & 18 & 17.3 & 52 & 17.3 \\
\hline Very likely & 14 & 7.1 & 7 & 6.7 & 21 & 7.0 \\
\hline Total & 197 & 100.0 & 104 & 100.0 & 301 & 100.0 \\
\hline
\end{tabular}

Figure 3-11. Likelihood of Being Caught Driving Unlicensed

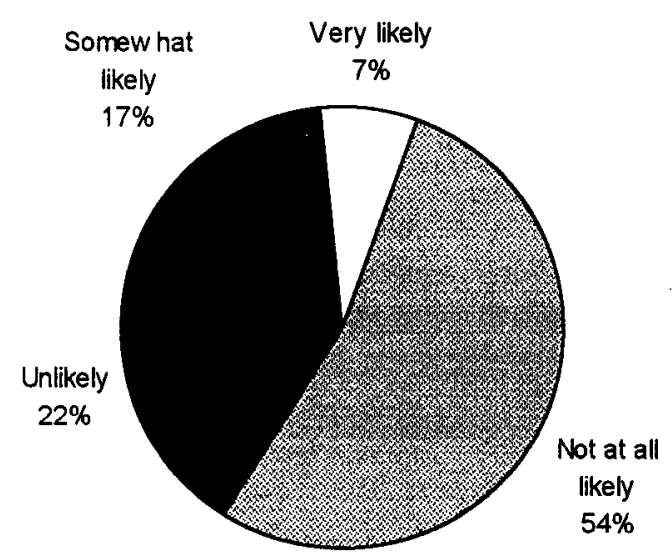

First Offenders

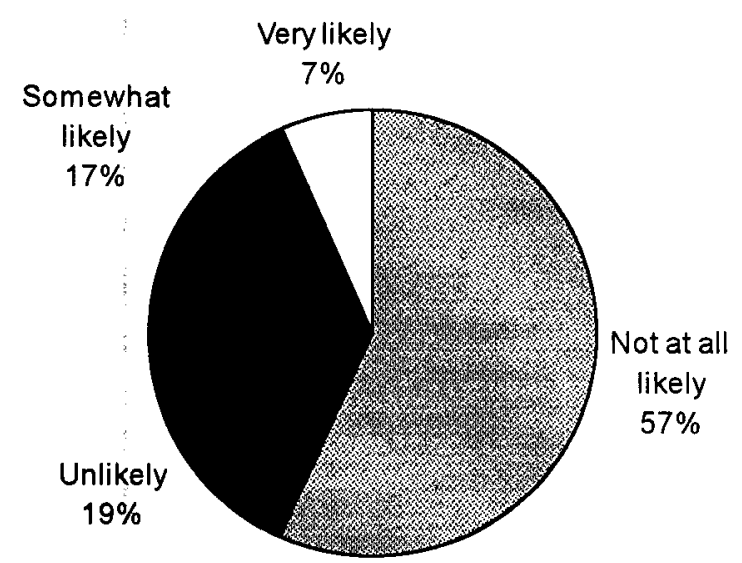

Multiple Offenders 


\subsection{The Functioning of ALR Systems}

The following observations can be made about the experience of the drivers with the breath test and administrative process in Maryland, California, and Delaware. Table 3-17 and Figures 3-12 and 3-13 show that important minorities of offenders did not take breath tests at the time of arrest. Except in California, the proportions were higher for repeat offenders, representing almost half in Maryland.

One would have expected (as is the case for Maryland) that a large percent of DUI offenders who did not take a breath test at the time of arrest would have been charged with refusing the breath test. The following are some possible explanations for the lower percentages in Pennsylvania, California, and Delaware: (1) A significant percent of the DUI offenders who did not take a breath test in Pennsylvania, California, and Delaware could have had blood drawn for BAC analysis (and would not be charged with test refusal); (2) In Pennsylvania, the license suspension period is the same for test refusals and test failures, so these offenders may not be charged with test refusal; (3) In Delaware, drivers who refuse chemical testing must sign an "implied consent" form (not a "test refusal" form), so they may not recognize being charged with refusing the breath test; or (4) The DUI offenders did not understand what a refusal charge meant.

Table 3-17. DUI Offender Experience With the Breath Test at Time of Arrest

\begin{tabular}{|l|c|c|}
\hline & $\begin{array}{c}\text { \% DUI Offenders Who Did } \\
\text { Not Take a Breath Test at } \\
\text { Time of Arrest } \\
\text { (Question 27) }\end{array}$ & $\begin{array}{c}\text { \% DUI Offenders Who Did Not Take a } \\
\text { Breath Test Who Were Charged With } \\
\text { Refusing Test (Question 28) }\end{array}$ \\
\hline PA first offenders & $25 \%$ & $8 \%$ \\
\hline PA multiple offenders & $31 \%$ & $16 \%$ \\
\hline MD first offenders & $20 \%$ & $85 \%$ \\
\hline $\begin{array}{l}\text { MD multiple } \\
\text { offenders }\end{array}$ & $43 \%$ & $92 \%$ \\
\hline CA first offenders & $24 \%$ & $12 \%$ \\
\hline CA multiple offenders & $24 \%$ & $35 \%$ \\
\hline DE first offenders & $17 \%$ & $8 \%$ \\
\hline DE multiple offenders & $26 \%$ & $25 \%$ \\
\hline All first offenders & $22 \%$ & $18 \%$ \\
\hline All multiple offenders & $29 \%$ & $38 \%$ \\
\hline Total & $24 \%$ & $25 \%$ \\
\hline
\end{tabular}


Figure 3-12. Percent DUI Offenders Who Did Not Take Breath Test

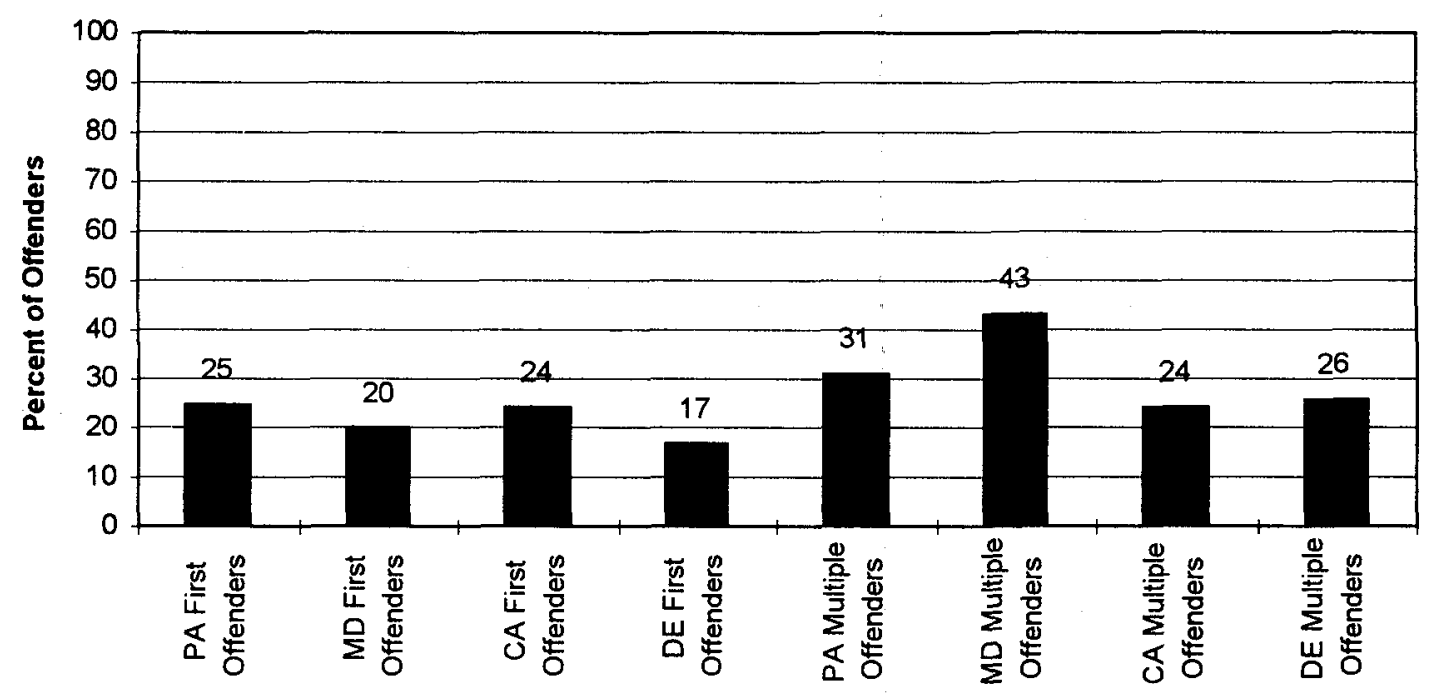

Figure 3-13. Percent DUI Offenders Who Did Not Take Breath Test Who Were Charged With Refusing Breath Test

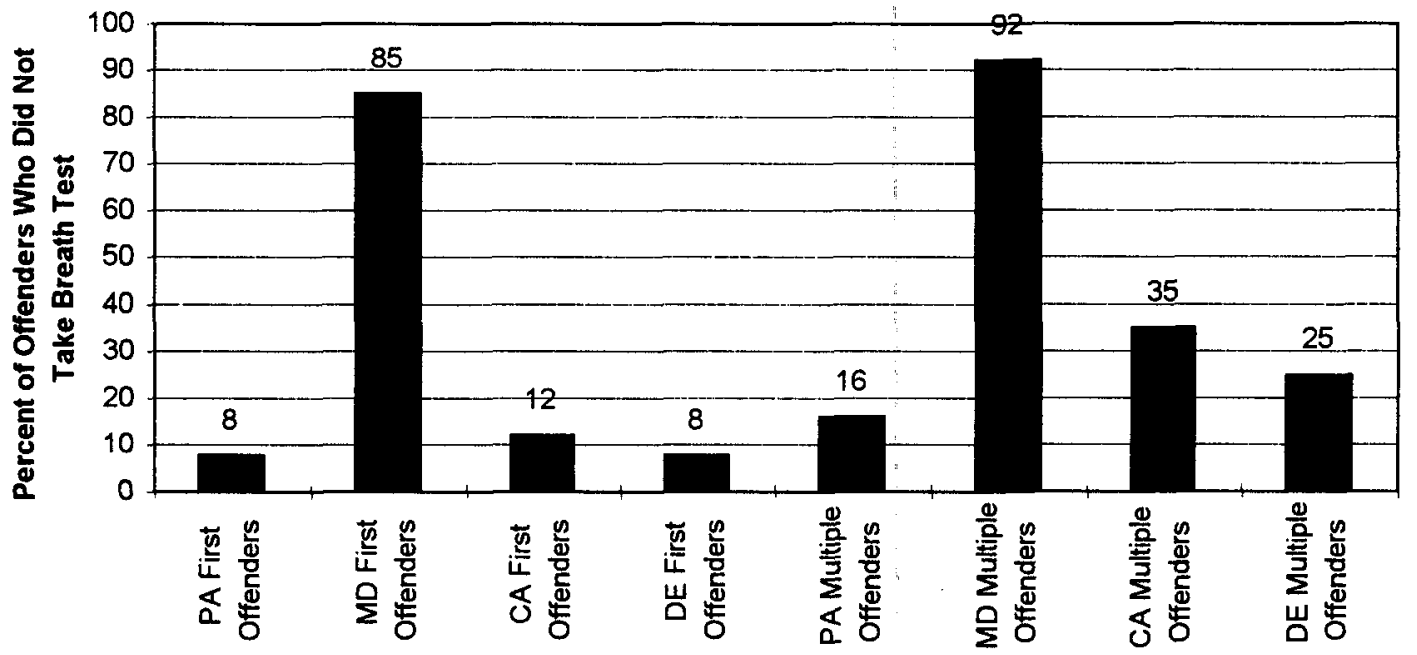


Table 3-18 and Figures 3-14 and 3-15 summarize the experience of DUI offenders in ALR states with the administrative process. Nearly a third of first offenders were ignorant of the possibility of administrative license revocation at the time of their offense. Unreasonable as it may be, this was also true of one out of six multiple offenders. Such people obviously could not have been deterred by the ALR law. Among the ALR states, Maryland produced the highest proportion of demands for hearings, with more than half saying they requested them. Maryland drivers also more frequently attended the hearings. They were more frequently rewarded by having their license returned. First offenders were more likely to succeed in all states. Only in Delaware are police required to attend all administrative hearings, which explains the difference in police attendance among the three states (see note at bottom of Table 318). 
Table 3-18. Experience/Knowledge of DUI Offenders with the Administrative Process

\begin{tabular}{|c|c|c|c|c|c|c|}
\hline & \multicolumn{2}{|c|}{ Maryland } & \multicolumn{2}{|c|}{ California } & \multicolumn{2}{|c|}{ Delaware } \\
\hline & $\begin{array}{c}\text { First } \\
\text { Offenders }\end{array}$ & $\begin{array}{c}\text { Multiple } \\
\text { Offenders }\end{array}$ & $\begin{array}{c}\text { First } \\
\text { Offenders }\end{array}$ & $\begin{array}{l}\text { Multiple } \\
\text { Offenders }\end{array}$ & $\begin{array}{c}\text { First } \\
\text { Offenders }\end{array}$ & $\begin{array}{c}\text { Multiple } \\
\text { Offenders }\end{array}$ \\
\hline $\begin{array}{l}\text { \% Requesting } \\
\text { Administrative } \\
\text { Hearing (Question } \\
\text { 30) }\end{array}$ & $65 \%$ & $59 \%$ & $25 \%$ & $21 \%$ & $33 \%$ & $38 \%$ \\
\hline $\begin{array}{l}\% \text { of Those } \\
\text { Requesting Hearing } \\
\text { Who Attended } \\
\text { Administrative } \\
\text { Hearing (Question } \\
\text { 31) }\end{array}$ & $98 \%$ & $83 \%$ & $63 \%$ & $47 \%$ & $75 \%$ & $88 \%$ \\
\hline $\begin{array}{l}\% \text { of Those } \\
\text { Requesting Hearing } \\
\text { for Which Arresting } \\
\text { Police Attended } \\
\text { Administrative } \\
\text { Hearing (Question } \\
32)^{*}\end{array}$ & $10 \%$ & $47 \%$ & $7 \%$ & $15 \%$ & $55 \%$ & $71 \%$ \\
\hline $\begin{array}{l}\% \text { of Those } \\
\text { Requesting \& } \\
\text { Attending } \\
\text { Administrative } \\
\text { Hearing Whose } \\
\text { License Was } \\
\text { Returned (Question } \\
\text { 33) }\end{array}$ & $47 \%$ & $40 \%$ & $13 \%$ & $8 \%$ & $34 \%$ & $18 \%$ \\
\hline $\begin{array}{l}\% \text { of DUI Offenders } \\
\text { Aware of } \\
\text { Administrative } \\
\text { License Revocation } \\
\text { Laws Before Arrest } \\
\text { (Question 29) }\end{array}$ & $67 \%$ & $84 \%$ & $66 \%$ & $80 \%$ & $68 \%$ & $72 \%$ \\
\hline
\end{tabular}

* In California, police are not required to attend administrative hearings. In Maryland, police need only attend the administrative hearings if they are subpoenaed. In Delaware, police must attend all administrative hearings. 
Figure 3-14. Administrative Process Experience

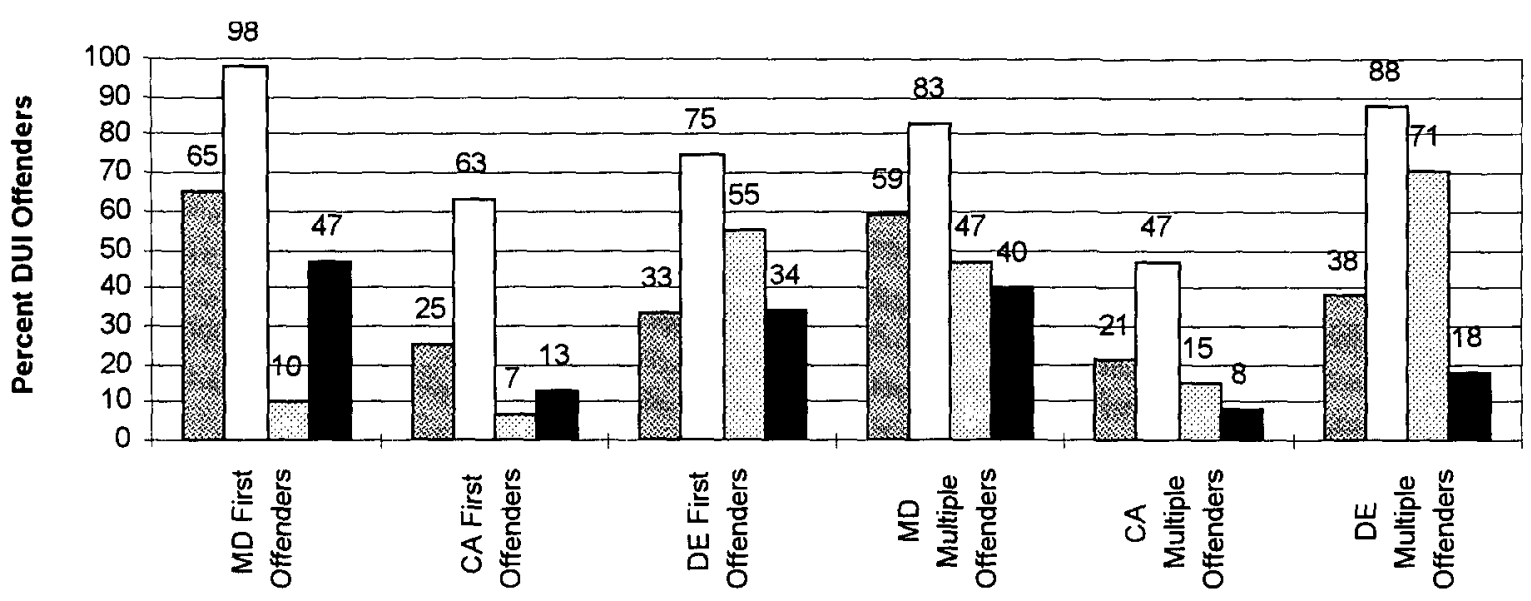

\% Requesting Adm. Hearing

$\square \%$ Requested Hearing \& Attended

\% \% Requested Hearing \& Police Attended

— Requested Hearing \& License Returned

Figure 3-15. Awareness of Administrative Process Before DUI Arrest

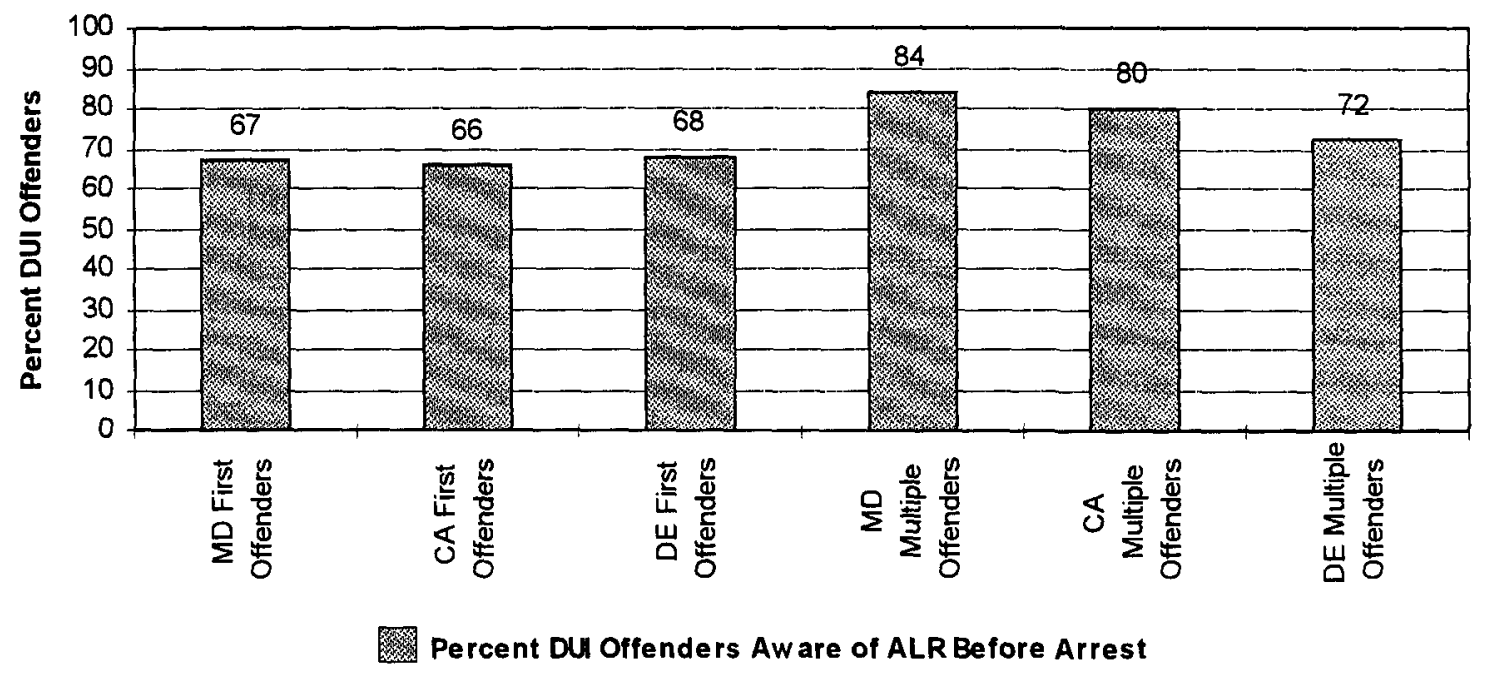


DUI offenders expect to get back into the system as shown in Table 3-19 and Figure 3-16. However, nontrivial proportions of multiple offenders (13 percent) indicated a low probability of relicensing.

Table 3-19. Likelihood DUI Offender Will Get License Back When Suspension/Revocation Ends (Question 36)

\begin{tabular}{|l|r|r|r|r|r|r|}
\hline \multirow{2}{*}{ Likelihood } & \multicolumn{2}{|c|}{ First Offenders } & \multicolumn{2}{c|}{ Multiple Offenders } & \multicolumn{2}{c|}{ Total } \\
\cline { 2 - 7 } & Number & Percent & Number & Percent & Number & Percent \\
\hline Not at all likely & 30 & 6.4 & 19 & 9.6 & 49 & 7.3 \\
\hline Unlikely & 6 & 1.3 & 6 & 3.0 & 12 & 1.8 \\
\hline Somewhat likely & 22 & 4.7 & 26 & 13.1 & 48 & 7.2 \\
\hline Very likely & 412 & 87.7 & 147 & 74.2 & 559 & 83.7 \\
\hline Total & 470 & 100.0 & 198 & 100.0 & 668 & 100.0 \\
\hline
\end{tabular}

Figure 3-16. Likelihood Licenses Returned

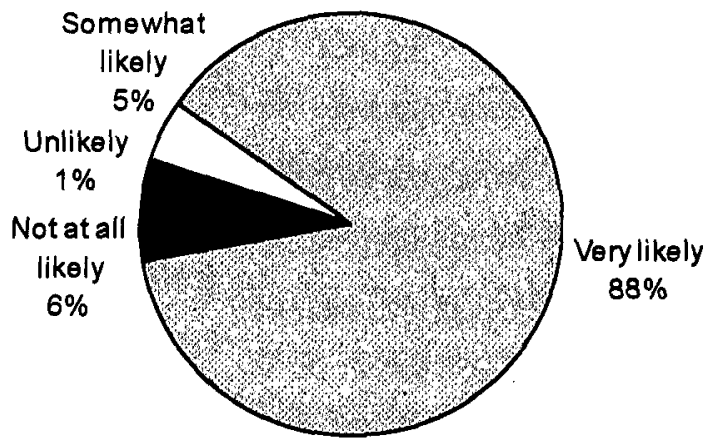

First Orfenders

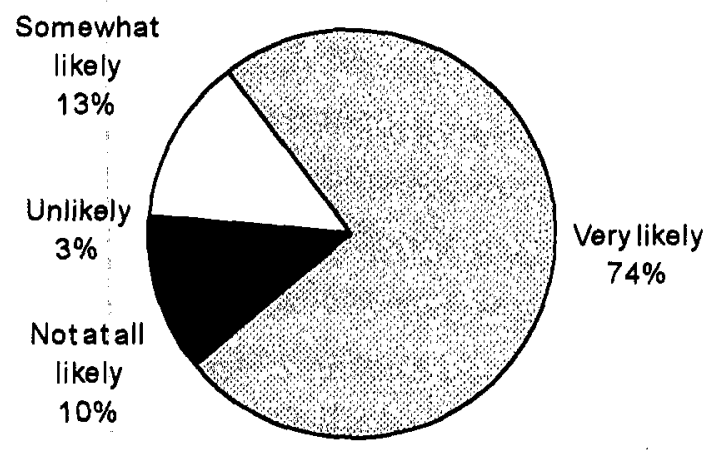

Multiple Orfenders 


\subsection{Other Findings Related to Safety Among DUI Offenders}

On average, 2 percent of first offenders and 21 percent of multiple offenders were driving while unlicensed at the time of their arrest. Table 3-20 shows the number of DUI offenders possessing a valid license at the time of their DUI arrest.

Table 3-20. DUI Offenders With Valid License at Their Most Recent DUI Arrest (Question 4)

\begin{tabular}{|l|r|r|r|r|r|r|}
\hline \multirow{2}{*}{ Valid License? } & \multicolumn{2}{|c|}{ First Offenders } & \multicolumn{2}{c|}{ Multiple Offender } & \multicolumn{2}{c|}{ Total } \\
\cline { 2 - 7 } & Number & Percent & Number & Percent & Number & Percent \\
\hline Yes & 563 & 98.1 & 181 & 79.0 & 74.7 & 92.7 \\
\hline No & 11 & 1.9 & 48 & 21.0 & 59 & 7.3 \\
\hline Total & 114 & 1000 & 229 & 1000 & 803 & 100.0 \\
\hline
\end{tabular}

Many repeat offenders (nearly one in six) had more than one prior offense on their record in the past year, and declared priors were as high as five in 5 years. Table 3-21 summarizes the percent of multiple offenders with more than one prior DUI arrest.

Table 3-21. Prior DUI Arrest Records (Questions 7 and 8)

\begin{tabular}{|l|c|c|c|c|c|}
\hline $\begin{array}{l}\text { Percent of Multiple } \\
\text { Offenders With More } \\
\text { Than One Prior Arrest }\end{array}$ & \multicolumn{5}{|c|}{ State } \\
\cline { 2 - 6 } & Pennsylvania & Maryland & California & Delaware & Total \\
\hline Inlast Year & $18 \%$ & $21 \%$ & $15 \%$ & $13 \%$ & $16 \%$ \\
\hline In last five years & $81 \%$ & $100 \%$ & $78 \%$ & $67 \%$ & $80 \%$ \\
\hline
\end{tabular}


Multiple offenders were more likely to fail to wear seat beits. This accords with the understanding that repeat DUI offenders tend to engage in other unsafe driving behaviors. Table 3-22 summarizes the number of DUI offenders who reported wearing a seat belt at the time of their DUI arrest.

Table 3-22. DUI Offenders Who Reported Wearing Seat Belt at the Time of DUI Arrest (Question 23)

\begin{tabular}{|l|r|r|r|r|r|r|}
\hline \multirow{2}{*}{$\begin{array}{c}\text { Wearing } \\
\text { Seat Belt? }\end{array}$} & \multicolumn{2}{|c|}{ First Offenders } & \multicolumn{2}{c|}{ Multiple Offenders } & \multicolumn{2}{c|}{ Total } \\
\cline { 2 - 7 } & Number & Percent & Number & Percent & Number & Percent \\
\hline Yes & Nou & 70.2 & 136 & 59.6 & 536 & 67.2 \\
\hline No & 170 & 29.8 & 92 & 40.2 & 262 & 32.8 \\
\hline Total & 570 & 100.0 & 228 & 100.0 & 798 & 100.0 \\
\hline
\end{tabular}

Registration of vehicles in the name of persons other than the DUI offender was relatively uncommon, even for multiple offenders. It was expected that this would occur as a means of avoiding insurance surcharges, but the expectations were disconfirmed. Table 3-23 and Figure 3-17 display the ownership of the car driven by the DUI offender at the time of DUI arrest. 
Table 3-23. Ownership of the Vehicle Driven at the Time of DUI Arrest (Question 22)

\begin{tabular}{|c|c|c|c|c|c|c|}
\hline \multirow[b]{2}{*}{ Owner } & \multicolumn{2}{|c|}{ First Offenders } & \multicolumn{2}{|c|}{ Multiple Offenders } & \multicolumn{2}{|c|}{ Total } \\
\hline & Number & Percent & Number & Percent & Number & Percent \\
\hline Self: & 426 & 74.0 & 172 & 74.8 & 598 & 742 \\
\hline Spouse & 25 & 4.3 & 11 & 4.8 & 36 & 4.5 \\
\hline $\begin{array}{l}\text { Relative (other than } \\
\text { spouse) }\end{array}$ & 65 & 111.3 & 16 & 7.0 & 81 & 10.0 \\
\hline $\begin{array}{l}\text { Friend (living in } \\
\text { same household) }\end{array}$ & 11 & 1.9 & 9 & 3.9 & 20 & 2.5 \\
\hline $\begin{array}{l}\text { Friend (nof living in } \\
\text { same household) }\end{array}$ & 22 & 3.8 & 12 & 5.2 & 34 & 4.2 \\
\hline Prior owner & 7 & 1.2 & 2 & 0.9 & 9 & 1.1 \\
\hline Employer & 10 & 1.7 & 6 & 2.6 & 16 & 2.0 \\
\hline Rental car & 8 & 1.4 & 1 & 0.4 & 9 & 1.1 \\
\hline Other & 2. & 0.3 & 1 & 0.4 & 3 & 0.4 \\
\hline Total & 576 & 100.0 & 230 & 100.0 & 806 & 100.0 \\
\hline
\end{tabular}

Figure 3-17. Vehicle Ownership

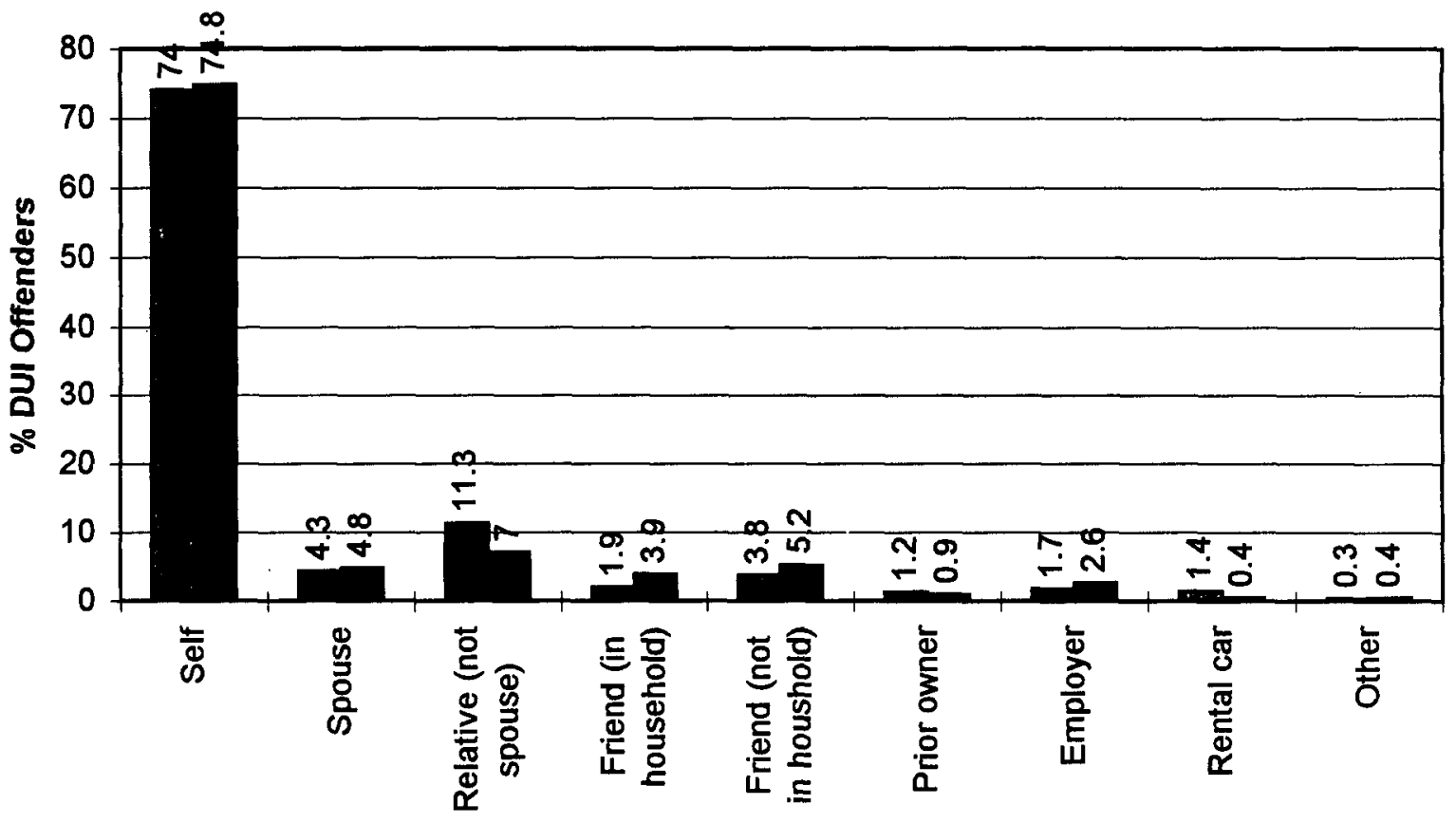

First Offenders (\%) Dultiple Offenders (\%) 
Crashes accompanied 17 percent of all DUI arrests. The vast bulk of arrests were based on moving violations or equipment violations. One implication of this fact is that the experiences of DUI offenders as a group are incommensurate with those of crash victims. Table 3-24 and Figure 3-18 summarize the reasons police stopped the DUI offender at the time of DUI arrest.

Table 3-24. Reason Police Stopped Vehicle at the Time of DUI Arrest (Question 24)

\begin{tabular}{|c|c|c|c|c|c|c|}
\hline \multirow{2}{*}{$\begin{array}{l}\text { Reason } \\
\text { Stopped }\end{array}$} & \multicolumn{2}{|c|}{ First Offenders } & \multicolumn{2}{|c|}{ Multiple Offenders } & \multicolumn{2}{|c|}{ Total } \\
\hline & Number & Percent & Number & Percent & Number & Percent \\
\hline Orash & 102 & 17.8 & 38 & 16.5 & 140 & 174 \\
\hline Moving violation & 380 & 66.2 & 152 & 66.1 & 532 & 66.2 \\
\hline 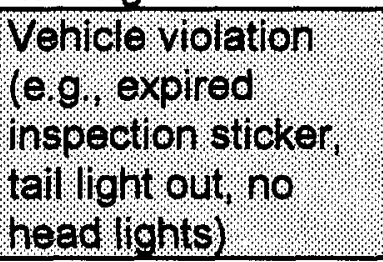 & 46 & 80 & 18 & 7.8 & 64 & 80 \\
\hline $\begin{array}{l}\text { Roadblock or } \\
\text { sobriety checkpoint }\end{array}$ & 18 & 3.1 & 7 & 3.0 & 25 & 3.1 \\
\hline Other & 28 & 49 & 15 & 6.5 & 43 & 53 \\
\hline Total & 574 & 100.0 & 230 & 100.0 & 804 & 100.0 \\
\hline
\end{tabular}


Figure 3-18. Reasons Police Stopped Vehic/e

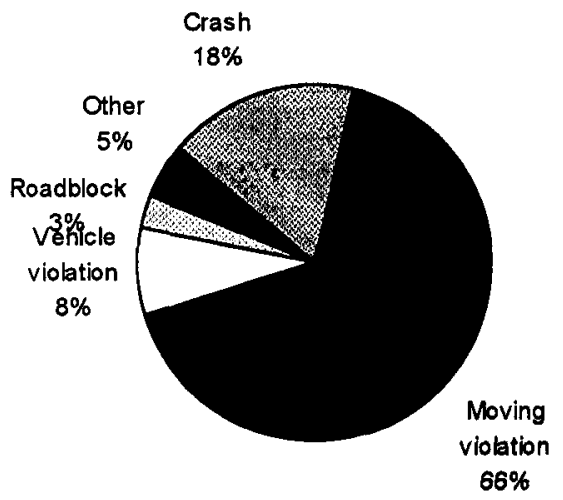

First Offenders

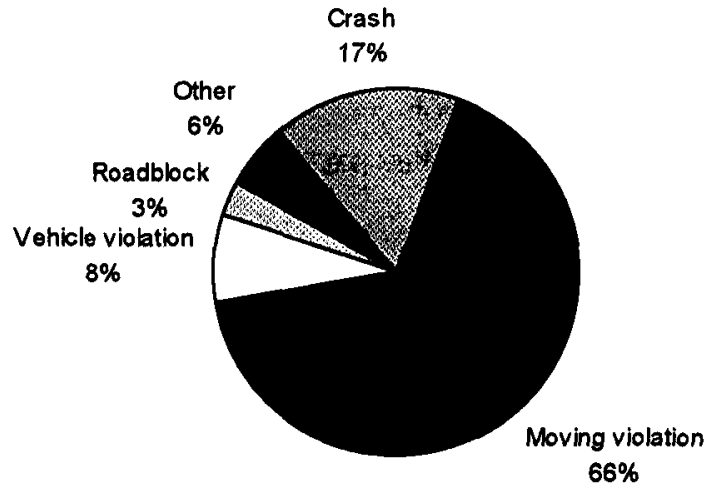

Multiple Offenders

Most offenders lived in households with other employed persons. One implication of this is that even if the DUI offender were to lose his/her employment, most of the households would be able to count on the income of others for survival. Table 3-25 tabulates the number of currently employed household members other than the DUI offender.

Table 3-25. Number Currently Employed Household Members of the DUI Offender (Question 49)

\begin{tabular}{|l|r|r|r|r|r|r|}
\hline \multirow{2}{*}{ Number Employed } & \multicolumn{2}{|c|}{ First Offenders } & \multicolumn{2}{c|}{ Multiple Offenders } & \multicolumn{2}{|c|}{ Total } \\
\cline { 2 - 7 } & Number & Percent & Number & Percent & Number & Percent \\
\hline None & 181 & 32.6 & 72 & 32.4 & 253 & 32.6 \\
\hline One & 211 & 38.0 & 91 & 41.0 & 302 & 38.9 \\
\hline Two or more & 163 & 29.4 & 59 & 26.6 & 222 & 28.6 \\
\hline Total & 555 & 100.0 & 222 & 100.0 & 777 & 100.0 \\
\hline
\end{tabular}




\subsection{Administration of Surveys to Spanish Speaking DUI Offenders}

In the course of pretesting, it was found that some DUl offenders, mainly immigrants from Mexico, had difficulty comprehending English. Marin County, California and Chester County, Pennsylvania addressed this problem with special classes in the Spanish language. The DUI offender questionnaire was translated into Spanish in an attempt to reach this group.

The Spanish questionnaire met several obstacles in practice, and in the end the attempt was abandoned. The translation was a good one for the purpose, being done by a native New Mexico Hispanic sociologist. However, it turned out that members of the target group were often illiterate in Spanish as well as English. Short of individual interviews, which were judged too expensive, the group administration required the instructors to read the questions. In at least some circumstances the instructors seemed to hint at the "correct" answers, thus influencing the supposedly independent responses.

The Spanish questionnaire raised a problem that was not recognized at the time the interview was prepared, which is that the conception of jobs and employment does not correspond with the understanding of some segments of society. Many of the Mexican immigrants in the sample did not have jobs in the sense that is generally understood. For example, some workers, especially in agriculture, worked at a different "job" every day. The questions would not be meaningful in that situation. Furthermore, many of the Hispanics, and doubtless some of the English speakers, never possessed a driver's license and thus could not have been greatly influenced by that sanction. (However, all drove.) The questions concerning license revocation made little sense to them. Other, similar, problems were discovered, such as the fact that many Spanish speakers in Pennsylvania lived in company dormitories, and lacked understanding of the journey to work.

Although an attempt was made to administer the Spanish questionnaire despite these problems, the necessity to read and explain each question made these sessions lengthy and intrusive. The answers received were difficult to understand. The effort was abandoned and the data from the Spanish classes were not included in the final results. Of course, problems such as functional illiteracy and different understandings of employment probably affect some members of the mainstream classes, but it is impossible to identify the misleading cases.

The experience interviewing the Chester County, Pennsylvania Hispanic class on Sunday morning, September 25, 1994 is illustrative of the problems encountered with this group. Although 35 were registered for the class, only 14 people attended. As anticipated, these people were not able to complete a paper-and-pencil survey on their own. The instructor read every question to them and waited for them to record their answers on the questionnaire. One man could neither read not write, but his neighbor volunteered to listen to his answer (after the instructor read each question) and write his answer on his questionnaire. The administration of the questionnaire in this manner took 80 minutes (compared to the 15-20 minutes when everyone read the questions and answered them on 
their own). Some components of the questionnaire were foreign to the Hispanic class (e.g., understanding the word "county", following skip patterns, circling answers, and providing scale responses for questions). Many of these people ride with someone to work, so a vehicle is not important for their employment. Although they are supposed to get a valid Pennsylvania license within 90 days of coming from Mexico, few ever do.

\subsection{Victim Survey Results}

The following summarizes the results of the victim survey, in addition to the impact on employment already discussed in Section 3.2. It must be remembered that these results are for a relatively small sample of victims (approximately 150) and they represent a very small percentage of the injuries in alcohol-related crashes. The majority of the injuries are suffered by the DUl offenders who cause these crashes (based on absolute numbers). In the following analysis, the question numbers noted on the tables refer to the Victim Questionnaire in Appendix C.

Membership in the victim group was defined in terms of unimpaired survivors of alcohol-related crashes. Over 75 percent of the victims were drivers of another vehicle involved in the crash (but not charged with DUI), as shown in Table 3-26.

Table 3-26. Involvement of Victims in the DUI Crash (Question 2)

\begin{tabular}{|c|c|c|c|c|c|c|}
\hline \multirow[b]{2}{*}{ Involvement } & \multicolumn{2}{|c|}{$\begin{array}{l}\text { Victims Not Treated } \\
\text { at Hospital }\end{array}$} & \multicolumn{2}{|c|}{$\begin{array}{c}\text { Victims Treated at } \\
\text { Hospital }\end{array}$} & \multicolumn{2}{|c|}{ Total } \\
\hline & Number & Percent & Number & Percent & Number & Percent \\
\hline $\begin{array}{l}\text { Passenger in } \\
\text { vehicle of driver } \\
\text { charged with DUI }\end{array}$ & 3 & 4.6 & 5 & 16.3 & 18.8 & 185 \\
\hline $\begin{array}{l}\text { Driver of another } \\
\text { vehicle (not } \\
\text { charged with DUI) }\end{array}$ & 57 & 87.7 & 53 & 66.3 & 110 & 75.9 \\
\hline $\begin{array}{l}\text { Passenger in } \\
\text { another vehicles } \\
\text { (driver not charged } \\
\text { with DUI) }\end{array}$ & 2 & 3.1 & 22 & 27.5 & 24 & 16.6 \\
\hline Pedestrian & 3 & 4.6 & 0 & 0.0 & 3 & 2.1 \\
\hline Total & 65 & 100.0 & 80 & 100.0 & 145 & 100.0 \\
\hline
\end{tabular}


Over 27 percent of the victims were uninjured and nearly half did not require medical treatment. Only about 15 percent required hospitalization. Table 3-27 summarizes the injury severity of the victims by state and total.

Table 3-27. Injury Severity of Crash Victims (Question 3)

\begin{tabular}{|c|c|c|c|c|c|c|c|c|}
\hline \multirow[b]{2}{*}{ Injury Severity } & \multicolumn{2}{|c|}{ Pennsylvania } & \multicolumn{2}{|c|}{ Califomia } & \multicolumn{2}{|c|}{ Delaware } & \multicolumn{2}{|c|}{ Total } \\
\hline & Number & Percent & Number & Percent & Number & Percent & Number & Percent \\
\hline Not infured & 24 & 44.4 & 2 & $5 \%$ & 14 & 241 & 40 & 274 \\
\hline $\begin{array}{l}\text { Injured, but not } \\
\text { treated at hospital }\end{array}$ & 6 & 11.1 & 8 & 23.5 & 12 & 20.7 & 26 & 17.8 \\
\hline $\begin{array}{l}\text { Treated for } \\
\text { at hospolat but no } \\
\text { overnighy stay } \\
\text { regulred }\end{array}$ & 18 & 33.3 & 17 & 508 & 22 & 379 & 57 & 390 \\
\hline $\begin{array}{l}\text { Hospitalized for } \\
\text { less than } 1 \text { week }\end{array}$ & 4 & 7.4 & 2 & 5.9 & 8 & 13.8 & 14 & 9.6 \\
\hline 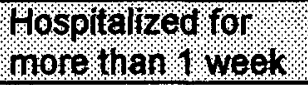 & 2 & 37. & 5 & $14 \%$ & 2 & 34 & 9 & 6.2 \\
\hline Total & 54 & 100.0 & 34 & 100.0 & 58 & 100.0 & 146 & 100.0 \\
\hline
\end{tabular}

Most of the damage was to vehicles. More than 57 percent of the crash victims reported that their vehicle was damaged such that it could not be driven away from the crash scene, as shown in Table 3-28. 
Table 3-28. Damage to Vehicle Resulting from DUI Crash (Question 4)

\begin{tabular}{|c|c|c|c|c|c|c|c|c|}
\hline \multirow[b]{2}{*}{ Vehicle Damage } & \multicolumn{2}{|c|}{ Pennsylvania } & \multicolumn{2}{|c|}{ Califomia } & \multicolumn{2}{|c|}{ Delaware } & \multicolumn{2}{|c|}{ Total } \\
\hline & Number & Percent & Number & Percent & Number & Percent & Number & Percent \\
\hline Do nol drive & 1 & 109 & 4 & 118 & 1 & 18 & 6 & 42 \\
\hline $\begin{array}{l}\text { No loss of vehicle } \\
\text { regularly driven }\end{array}$ & 13 & 24.5 & 1 & 2.9 & 10 & 17.5 & 24 & 16.7 \\
\hline $\begin{array}{l}\text { Vehicle damaged. } \\
\text { but still able to } \\
\text { drive }\end{array}$ & 14 & 26.4 & 6 & 176 & 11 & 19.3 & 31 & 215 \\
\hline $\begin{array}{l}\text { Vehicle damaged } \\
\text { so could not drive } \\
\text { away from crash, } \\
\text { but since repaired }\end{array}$ & 5 & 9.4 & 5 & 14.7 & 13 & 22.8 & 23 & 16.0 \\
\hline $\begin{array}{l}\text { Venicle totaled in } \\
\text { crash }\end{array}$ & 20 & $37 \%$ & 18 & 52.9 & 22 & 38.6 & 60 & 41.7 \\
\hline Total & 53 & 100.0 & 34 & 100.0 & 57 & 100.0 & 144 & 100.0 \\
\hline
\end{tabular}

Table 3-29 compares the remaining results from the crash victim survey with comparable results from the DUI offender survey. Ten percent fewer crash victims were employed at the time of their DUI crash as compared to DUI offenders employed at the time of their DUI arrest. A larger percent of crash victims was employed in professional jobs than DUI offenders. The average tenure of crash victims at their current job was 8 months longer than the average tenure of DUI offenders at their current job. The DUI offenders worked more hours per week and earned slightly more per week than the crash victims. This may be a reflection of the overtime compensation afforded in the more common blue collar jobs of DUI offenders. Another explanation of the higher earnings of DUI offenders is that DUI offenders are predominantly males, and males on average tend to earn more than females. Both groups reported an almost identical weekly reduction in income (under $\$ 100 /$ week) as a result of the DUI crash or loss of license. 


\section{Table 3-29. Comparison of Crash Victim Survey and DUI Offender Survey Results}

\begin{tabular}{|c|c|c|c|}
\hline $\begin{array}{c}\text { Crash victim survey } \\
\text { question }\end{array}$ & $\begin{array}{c}\text { Crash victim } \\
\text { survey response }\end{array}$ & $\begin{array}{c}\text { DUl offender survey } \\
\text { question }\end{array}$ & $\begin{array}{c}\text { DUl offender } \\
\text { survey response }\end{array}$ \\
\hline $\begin{array}{l}\text { Employed at time of } \\
\text { crash (Question 9) }\end{array}$ & $80.8 \%$ & $\begin{array}{l}\text { Employed at time of DUl } \\
\text { arrest (Question } 13 \text { ) }\end{array}$ & $918 \%$ \\
\hline $\begin{array}{l}\text { Professional } \\
\text { employment at current } \\
\text { job (Question 7c) }\end{array}$ & $27.1 \%$ & $\begin{array}{l}\text { Professional employment at } \\
\text { current job (Question 11d) }\end{array}$ & $16.0 \%$ \\
\hline $\begin{array}{l}\text { Average tenure } \\
\text { (months) at current }{ }^{\circ} \\
\text { (Question } 7 \mathrm{a} \text { a) }\end{array}$ & 72 months & $\begin{array}{l}\text { Average tenure (months) at } \\
\text { current job (Question } 1 \text { larb) }\end{array}$ & 64 months \\
\hline $\begin{array}{l}\text { Average weekly hours } \\
\text { worked at current job } \\
\text { (Question 7d) }\end{array}$ & 38 hours/week & $\begin{array}{l}\text { Average weekly hours } \\
\text { worked at current job } \\
\text { (Question } 11 \mathrm{~g} \text { ) }\end{array}$ & 45 hours/week \\
\hline $\begin{array}{l}\text { Average weekly gross } \\
\text { eamings at current job } \\
\text { (Question } 7 \text { e) }\end{array}$ & $\$ 670$ week & $\begin{array}{l}\text { Average week gy gross } \\
\text { eamings at current job } \\
\text { (Question } 1 \mathrm{H} \text { ) }\end{array}$ & $\$ 717$ week \\
\hline $\begin{array}{l}\text { Average total } \\
\text { uncompensated lost } \\
\text { wages for those } \\
\text { employed at time of } \\
\text { crash (Question } 10 \mathrm{a} \text { ) }\end{array}$ & $\$ 682$ & N/A & N/A \\
\hline $\begin{array}{l}\text { Average difference } \\
\text { between regular pay } \\
\text { and disability pay for } \\
\text { those employed at time } \\
\text { of crash \& injured in } \\
\text { crash (Question } 10 \text { b) }\end{array}$ & $\$ 150$ & N/A & NIA \\
\hline $\begin{array}{l}\text { Average weekly } \\
\text { reduction in income for } \\
\text { those employed at time } \\
\text { of crash (Question } 10 \mathrm{c} \text { ) }\end{array}$ & $\$ 99$ & $\begin{array}{l}\text { Average weekly reduction in } \\
\text { income for those employed } \\
\text { at time of DUl arrest } \\
\text { (Question 20) }\end{array}$ & $\$ 95$ \\
\hline
\end{tabular}




\subsection{SUMMARY AND RECOMMENDATIONS}

This research indicates that employment consequences of administrative license revocation on DUI offenders are mainly restricted to the need to find alternative transportation. This is generally achieved by riding with others. Offenders see this as an inconvenience, but lost income is uncommon. An impact on established travel patterns is also noticed with regard to functions like shopping and especially for social and recreational purposes. This finding is a general one and is not related to the nature and length of revocation.

Some adaptation to loss of license is accomplished by depending on others, such as family and co-workers. Some is accomplished by driving while unlicensed; it is difficult to control this behavior through law because the population views the risk of apprehension as low.

Alcohol-involved crashes have a great impact on seriously injured victims. However, the proportion of DUI crashes producing serious injury is quite low. Most DUI is crash-free, and most crashes do not involve injury. Thus, the vast bulk of the impact of DUI falls on the offenders and not the "victims."

Some important experience regarding the study of DUI offenders was obtained in the course of this project. The method of obtaining information from offenders at alcohol highway safety schools and alcohol treatment programs worked very well for both first and multiple offenders literate in English. The schools and treatment programs were interested in the research study and were therefore cooperative and accommodating of the research requirements. A very high participation rate was obtained from the offenders. (Of course, they were somewhat of a captive audience and were not actually told that participation in the survey was voluntary.)

Another implication of this research study is that the needs of Spanish speaking DUI offenders may not be adequately addressed by the current alcohol education and treatment program methods. This group is very different from the DUI offenders for whom English is the primary language, in terms of culture, education, employment, and driving experience. A Spanish version of the DUI offender questionnaire was developed for administration in the special classes conducted in Spanish in California and Pennsylvania. The Spanish questionnaire met several obstacles in practice, and in the end the attempt was abandoned when it turned out that members of the target group were often illiterate in Spanish as well as English, and were not able to complete a paperand-pencil survey on their own. Also, some components of the questionnaire were foreign to the Hispanic classes.

The Spanish speaking respondents raised a problem that was not recognized at the time the interview was prepared, which is that our conception of jobs and employment does not correspond with the understanding of some segments of society. Many of the Mexican immigrants in the sample worked at a different "job" every day. Furthermore, many of the 
Hispanics never possessed a driver's license and thus could not have been greatly influenced by that sanction. The questions concerning license revocation made little sense to them. Other, similar, problems were discovered, such as the fact that many Spanish speakers in Pennsylvania lived in company dormitories and lacked understanding of the journey to work.

This research has also found that administrative license systems differ in their efficiency. In some places, represented by Maryland, hearings are almost routinely requested and they often result in return of the license. In others, including both California and Delaware, few requests are made and few are successful in canceling the penalty. A partial explanation may be found, as in Delaware and to a limited extent in Maryland, in the policy of demanding police attendance at hearings and restoring the license of drivers if police do not attend.

Policy recommendations based on these findings are:

1. One should not expect loss of jobs and income from administrative license revocation as great as 90 days for first offenders. Since such revocation has safety benefits, continued support for the adoption of administrative license revocation policies is recommended.

2. The data indicate no strong reason to prefer one form or duration of ALR over another, from the viewpoint of minimizing economic consequences.

3. Because the population perceives the risk of apprehension for unlicensed driving as very low, more should be done to increase the rate of detection, and such efforts should be widely publicized.

4. States should facilitate license reinstatement at the end of the sanction period to encourage drivers to reenter the licensing system.

5. Since the public is still not familiar with administrative license revocation, more resources should be devoted to publicizing this remedial action in order to achieve general deterrence.

The data in this study show that administrative license revocation does not have a major impact on the DUI offender's job and income. An important reason for this is the willingness of offenders deprived of licenses to continue driving. Although they may drive more safely than they did when licensed, presumably even greater safety might be accomplished if the license revocation were more visibly enforced. However, to the extent that the revocation is complied with, there may occur a greater impact on jobs and income than noted. This general issue requires exploration.

Several issues amenable to future research have been identified in the course of this project. A first topic for further research concerns whether driving would be further 
reduced with vehicle sanctions, i.e., policies designed to separate would-be drunk driving offenders from access to vehicles. A good model might be Minnesota's license plate confiscation law, applicable to all vehicles driven or owned by multiple offenders. Alan Rodgers (1994) has shown that this law decreases DUI recidivism, but he did not explore the economic consequences of this policy.

A second topic which was not addressed because of contract specifications, but which is related, concerns the direct economic impact of the DUI conviction in the matter of fines, legal expenses, program fees, and insurance surcharges. These costs are quite likely to exceed the income impacts investigated in this report. One should explore differences in these costs by the financial status of the offenders. It is likely that these costs reduce the ability of the offenders to gain access to vehicles and therefore lower DUI recidivism as a collateral matter.

More is needed on enforcing the prohibition of driving while suspended or revoked. What is or would be the impact of increasing checkpoints, whether as an aspect of sobriety checkpoints or separate operations (which could be held during the day and at different kinds of sites)? Would a requirement for licenses to be displayed in windshields produce less unlicensed driving? Technological "fixes" have been suggested, things like making licenses readable by roadside scanners identifying the age and sex of the owners so that police could identify probable unlicensed drivers. Would stiffer penalties deter unlicensed drivers more than they do the general population of potential DUls?

Finally, the population in this study very largely declares expectations of becoming relicensed, an outcome desirable at first glance because both knowledge and control efforts are enhanced by relicensing. However, the degree to which these expectations are fulfilled is unknown, and the actual consequences or relicensing are not known. A panel study might follow a set of unlicensed drivers over time to check when and how they achieve relicensing, and compare those who do get licensed with those who do not in terms of subsequent driving history. It is possible that a failure to get relicensed is favorable for traffic safety due to the increased effort of the illegal driver to avoid detection. 


\subsection{LITERATURE REFERENCES}

Accident Facts, 1993 Edition, National Safety Council, 1993.

Blincoe, Lawrence J. and Faigin, Barbara M., The Economic Cost of Motor Vehicle Crashes, 1990, U.S. Department of Transportation, National Highway Traffic Safety Administration, DOT-HS-807-876, September 1992.

Evans, Leonard, Traffic Safety and The Driver (New York: Van Nostrand Reinhold, 1991).

Hagen, R.E., Effectiveness of License Suspension or Revocation for Drivers Convicted of Multiple Driving-Under-the-Influence Offenses (Sacramento, CA: Department of Motor Vehicles, 1977).

Hagen, R., McConnell, E. and Williams, R., Suspension and Revocation Effects on the DUI Offender (Sacramento, CA: Department of Motor Vehicles, 1980).

Hagen, R.E., Williams, R.L., and McConnell, E.J., "The Traffic Safety Impact of Alcohol Abuse Treatment as Alternative to Mandated Licensing Controls," Accident Analysis and Prevention, Vol. 11, pp. 275-291, 1979.

Highway Safety Research Center, An Initial Evaluation of the North Carolina Statewide Alcohol and Drug Education Traffic Schools Conducted by the UNC Highway Safety Research Centers. Executive Summary (Chapel Hill, NC: University of North Carolina Highway Safety Research, 1983).

Johnson, Delmas Maxwell, "The Effects of Administrative License Revocation on Employment: A Preliminary Report," Office of Alcohol and State Programs, Traffic Safety Programs, National Highway Traffic Safety Administration, August 1986.

Kedjidjian, Catherine B., "Cut Crashes, Cut Costs," Traffic Safety, July-August 1994, pp. 12-15.

Knoebel, K.Y., Ross, H.L., Schmidt, S.L., and Decina, L.E., State of Delaware Driving Under the Influence (DUI) Program Evaluation: Final Report, Delaware Department of Public Safety, Contract No. 07-95-02, June 1995.

"License Revocation Requires Minimal Costs," Operation Buckle Down Dispatch, Vol. 3, No. 2, February 1994.

MADD Pennsylvania Victim Information Booklet, MADD PA State Office, Harrisburg, PA, 1992. 
Miller, Ted R., Ph.D., "The Cost of Injuries to Employers, Methods Supplement," U.S. Department of Transportation, National Highway Traffic Safety Administration, DOT-HS-807-971, April 1993.

Miller, Ted R., Ph.D., "The Cost of Injuries to Employers, A Traffic Safety Compendium," U.S. Department of Transportation, National Highway Traffic Safety Administration, DOT-HS-807-970, April 1993.

Network of Employers for Traffic Safety Annual Report, NETS, Washington, DC, 1992.

Peck, R.C., Sadler, D.D., and Perrine, M.W., "The Comparative Effectiveness of Alcohol Rehabilitation and Licensing Control Actions for Drunk Driving Offenders: A Review of The Literature," Alcohol, Drugs and Driving, Vol. 4, No. 15 (1986), pp. 39.

Popkin, C., Li, L., Lacey, J., Stewart, R., and Waller, P., An Initial Evaluation of the North Carolina Alcohol and Drug Education Traffic Schools. Volume I (Chapel Hill, NC: University of North Carolina Highway Safety Research Center, 1983).

Popkin, C., Stewart, R., and Lacey, J., A Follow-Up Evaluation of North Carolina's Alcohol and Drug Education Traffic Schools and Mandatory Substance Abuse Assessments: Final Report (Chapel Hill, NC: University of North Carolina Highway Safety Research Center, 1988).

Rodgers, Alan, "Effect of Minnesota's License Plate Impoundment Law on Recidivism of Multiple DWI Offenders," Alcohol, Drugs, and Driving, Vol. 10, No. 2 (1994), pp. 127-134.

Ross, $\mathrm{H}$. Laurence, Administrative License Revocation for Drunk Drivers: Options and Choices in Three States (Washington, DC: AAA Foundation for Traffic Safety, April 1991).

Ross, H., McCleary, R. and LaFree, G., "Can Mandatory Jail Laws Deter Drunk Driving? The Arizona Case," Journal of Criminal Law and Criminology, Vol. 81, No. 1 (1990), pp. 155-172.

Ross, H. Laurence, Confronting Drunk Driving: Social Policy for Saving Lives (New Haven, CT: Yale University Press, 1992).

Ross, H. Laurence and Gonzales, Phillip, "Effects of License Revocations on DrunkDriving Offenders," Accident Analysis and Prevention, Vol. 20, No. 5 (1988), pp. 379-391.

Ross, $H$. and Voas, R., The New Philadelphia Story: The Effects of Severe Punishment for Drunk Driving (Washington, DC: AAA Foundation for Traffic Safety, 1989). 
Sadler, D.D. and Perrine, M.W., An Evaluation of the California Drunk Driving Countermeasure System: Volume 2. The Long-Term Traffic Safety. Impact of a Pilot Alcohol Abuse Treatment as an Alternative to License Suspensions (Sacramento, CA: Department of Motor Vehicles, 1984).

Salzberg, P.M., Hauser, R., and Klingberg, C.L., "License Revocation and Alcoholism Treatment Programs for Habitual Traffic Offenders." Unpublished report prepared for Department of Licensing, Olympia, WA, 1981.

Staplin, L., Knoebel, K., et al., "Effectiveness of Current Sanctions Against Habitual Offenders," Pennsylvania Department of Transportation, No. 86-16, March 1989.

Tashima, H.N. and Peck, R.C., "An Evaluation of the Specific Deterrent Effects of Alternative Sanctions for First and Repeat DUI Offenders," An Evaluation of the California Drunk Driving Countermeasure System, Volume 3. (Sacramento, CA: California Department of Motor Vehicles, 1986).

U.S. Department of Transportation, National Highway Traffic Safety Administration, Police Time and Costs Associated With Administrative License Revocation, December 1993.

U.S. Department of Transportation, National Highway Traffic Safety Administration, Digest of State Alcohol-Highway Safety Related Legislation, Fourteenth Edition, January 1, 1996.

U.S. Department of Transportation, National Highway Traffic Safety Administration, Administrative License Revocation: Resource Manual, July 1992.

U.S. Department of Transportation, National Highway Traffic Safety Administration, Source of Payment for the Medical Cost of Motor Vehicle Injuries in the United States, DOT-HS-807-800, January 1992.

U.S. Department of Transportation, National Highway Traffic Safety Administration, Alcohol Limits for Drivers: A Report on the Effects of Alcohol and Expected Institutional Responses to New Limits, Report to Congress, February 1991.

Waller, P.C., "Licensing and Other Controls of The Drinking Driver," Journal of Studies on Alcohol, Suppl. 10 (1985), pp. 150-160.

Wells-Parker, E. and Cosby, P.J., "Behavioral and Employment Consequences of Driver's License Suspension for Drinking and Driving Offenders," Journal of Safety Research, Vol. 19 (1988), pp. 5-20. 
Wells-Parker, E. and Cosby, P.J., "Impact of Driver's License Suspension on Employment Stability of Drunken Drivers," Social Science Report Series 87-3, Social Science Research Center, Mississippi State University, 1987. 


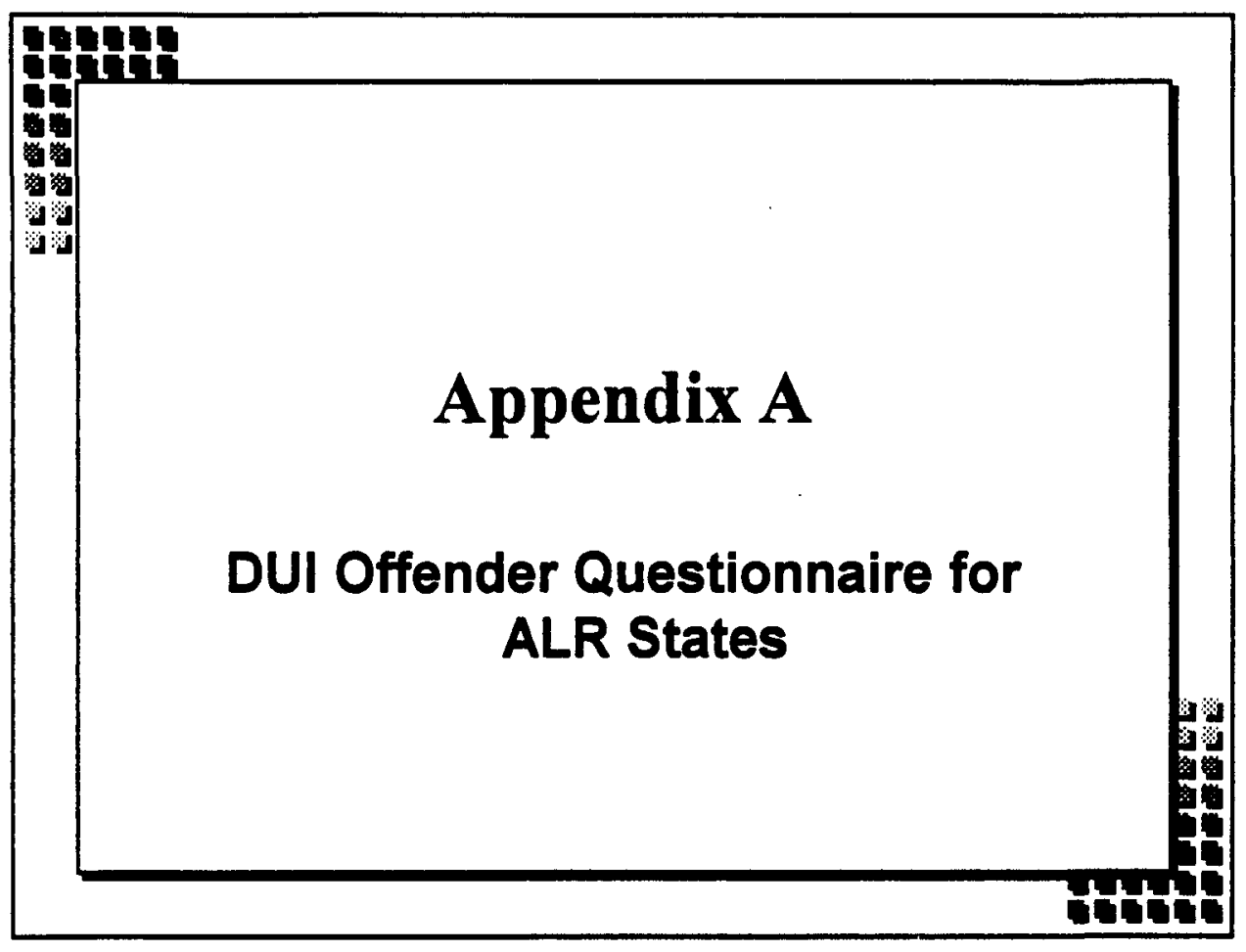




\section{STUDY OF EFFECTS OF LICENSE REVOCATION ON EMPLOYMENT - 1994}

Questionnaire for ALR States - Final Version 6

$$
\text { Interview Date: }
$$

There is an interest in finding out how your most recent DUI (driving under the influence) or DWI (driving while intoxicated) arrest has affected your life, especially your employment. In this questionnaire, this arrest is called "your most recent DUI arrest." The results of this anonymous survey will be used to make recommendations concerning state DUI/DWI laws. Thank you for your contribution to this study.

\section{Section 1. Introduction}

Q1. Which of the following best describes the reason you are attending today's program? [PLEASE CIRCLE THE MOST APPROPRLATE ANSWER.]

1. DUI/DWI arrest

2. Self referral

3. Employee assistance program referral

4. Other (please specify:

$>>>>$ IF YOU ARE NOT HERE TODAY BECAUSE OF A DUI/DWI ARREST, PLEASE SKIP TO Q41 ON PAGE 9. $<<<<$

Q2. In what county and state do you currently live?

County:

State:

Q3. What was the date (month and year) and location of your most recent DUI arrest (the one that has resulted in your attendance at this program)?

$\overline{\text { (Month) }}^{\prime} \frac{}{\text { (Year) }}$

(Location: City/town/township/borough, state)

Q4. Did you have a license at the time of this most recent DUI arrest?
1. Yes
2. No [If No, SKIP to Q6.]

Q5. When did you first lose your license because of this most recent DUI arrest (month and year)?

$\frac{1}{\text { (Month) }} \frac{\text { OR }}{\text { (Year) }} \quad \begin{aligned} & \text { I have not yet lost my license or started my license suspension. } \\ & \text { [PLEASE CIRCLE THE ABOVE LINE IF APPROPRLATE.] }\end{aligned}$

Q6. Was this most recent DUI arrest your FIRST DUI arrest since you started driving?
1. Yes [If FIRST DUI arrest, SKIP to Q9.]
2. No

Q7. How many total DUI arrests (including this most recent one) have you had in the last year?

Q8. How many total DUI arrests (including this most recent one) have you had in the last 5 years? 
Section 2. Employment, Schooling, Job Search, and Not Employed Periods in 1992/1993/1994

Q9. We would now like you to tell us (to the best of your ability) about your employment from January 1st of 1992 to the present. On the monthly 1992/1993/1994 calendar below, please enter a number from the following list (1-7) in each month biock to show your activity that month. If more than one activity applied in a month, enter the numbers for all applicable activities for the month. Choose from these seven categories:

1. Employment (any activity from which you received income, including full-time employment, part-time employment, self employment, and military service)

2. School attendance (high school, college, trade school)

3. Unemployment, during which time you were searching for a job

4. Not working of your own choice (i.e., you were NOT searching for a job)

5. Disability

6. Retirement

7. Jail

Please enter at least one number (from 1-7) in all applicable months below:

\begin{tabular}{||c||c|c|c|c|c|c|c|c|c|c|c|c||}
\hline \hline 1992 & Jan & Feb & Mar & April & May & June & .July & Aug & Sept & Oct & Nov & Dec \\
\hline \hline 1993 & & & & & & & & & & & & \\
\hline 1994 & & & & & & & & & & & & \\
\hline
\end{tabular}

If you did NOT enter a "1" (employment) in any month block above, SKIP TO Q21 ON PAGE 6.

Q10. What changes took place in your employment and income because of your DUI and/or loss of license? [IF YOU NEED MORE ROOM, PLEASE WRITE ON THE BACK OF THIS PAGE.]

We would now like you to provide some additional information on the following pages for all jobs you held from January 1, 1992 to the present (those jobs corresponding to all "1s" on the monthly calendar above). Please follow these additional instructions:

1. Enter overlapping time periods if appropriate. For example, if you held two part-time jobs at the same time, provide information on both jobs.

2. If you changed jobs while working for the same employer during 1992, 1993, or 1994, please provide information on these two jobs separately. 


\section{STUDY OF EFFECTS OF LICENSE REVOCATION ON EMPLOYMENT - 1994}

Questionnaire for ALR States - Final Version 6

Please answer the following for your current job (or most recent job if currently NOT employed).

Q11a. When did you start work at your current job (or most recent job if you are currently NOT employed)?

Month: Year: 19

Q11b. When did you stop working at the job you referred to in Q11a?

Month: Year: 19

OR I am currently still employed at this job.

Q11c. Which of the following best describes the industry or type of employer of your current job (or most recent job if you are currently NOT employed)? [CIRCLE THE MOST APPROPRIATE ANSWER.]
1. Agriculture
5. Transportation
9. Finance/insurance/real estate
2. Mining
6. Utilities
10. Services
3. Construction
7. Wholesale trade
11. Local/state government
4. Manufacturing
8. Retail trade
12. Federal government

13. Military

14. Other (please specify:

Q11d. Which of the following best describes the type of work you do at your current job (or most recent job if you are currently NOT employed)? [CIRCLE THE MOST APPROPRIATE ANSWER.]
1. Professional
2. Technical
4. Sales: High-Level
5. Sales: Clerical
7. Service (e.g., food service)
10. Professional driver
3. Managerial
6. Non-Sales: Clerical
8. Craft/skilled worker
11. Laborer
12. Other (please specify:
9. Machine operator )

Q1le. What is/was your most recent one-way average commute distance from home to work for your current job (or most recent job)?

$$
\text { miles one-way (average) }
$$

Q11f. How would you describe your need to drive at your current job (or most recent job)? [CIRCLE ALL THAT APPLY.]

1. I don't require a vehicle to do my job.

2. I use my own vehicle to commute to work only.

3. I drive my own vehicle as part of my job sometimes.
4. I drive my own vehicle as part of my job every day.

5. I drive another vehicle as part of my job sometimes.

6. I drive another vehicle as part of my job every day.

Q11g. In an average week, how many hours do/did you work at your current job (or most recent job)? hours/week (average)

Q11h. In an average week, what are/were your gross earnings at your current job (or most recent job)? $\$$ /week average gross earnings (before taxes or withholdings)

Q11i. If you are not still working at this job, why did you leave? [CIRCLE ONE.]

1. Better opportunity

2. Layoff/termination
3. Medical/disability

4. DUT/loss of license
5. Relocation

6. Resignation/unsatisfactory job conditions
7. Return to school

8. End of temporary job 
Please answer the following for the job you held before the one you just described on the last page.

Q12a. (SKIP TO Q13 IF NO MORE JOBS HELD.) When did you start work at this next most recent job?

Month: Year: 19

Q12b. When did you stop working at this next most recent job?

Month: __ Year: $19 \_$OR I am currently still employed at this job.

Q12c. Which of the following best describes the industry or type of employer of this next most recent job? [CIRCLE THE MOST APPROPRLATE ANSWER.]
1. Agriculture
5. Transportation
9. Finance/insurance/real estate
2. Mining
6. Utilities
10. Services
3. Construction
7. Wholesale trade
11. Local/state government
4. Manufacturing
8. Retail trade
12. Federal government

13. Military

14. Other (please specify: )

Q12d. Which of the following best describes the type of work you did at this next most recent job? [CIRCLE THE MOST APPROPRLATE ANSWER.]
1. Professional
4. Sales: High-Level
7. Service (e.g., food service)
8. Craft/skilled worker
9. Machine operator
10. Professional driver
2. Technical
5. Sales: Clerical
11. Laborer
3. Managerial
6. Non-Sales: Clerical
12. Other (please specify: )

Q12e. What was your most recent one-way average commute distance from home to work for this next most recent job? miles one-way (average)

Q12f. How would you describe your need to drive at this next most recent job? [CIRCLE ALL THAT APPLY.]

1. I don't require a vehicle to do my job.

2. I use my own vehicle to commute to work only.

3. I drive my own vehicle as part of my job sometimes.
4. I drive my own vehicle as part of my job every day.

5. I drive another vehicle as part of my job sometimes.

6. I drive another vehicle as part of my job every day.

Q12g. In an average week, how many hours did you work at this next most recent job? hours/week (average)

Q12h. In an average week, what were your gross earnings at this next most recent job? $\$$ /week average gross earnings (before taxes or withholdings)

Q12i. If you are not still working at this job, why did you leave? [CIRCLE ONE.]

1. Better opportunity

2. Layoff/termination
3. Medical/disability

4. DUI/loss of license
5. Relocation

6. Resignation/unsatisfactory job conditions
7. Return to school

8. End of temporary job 
If you worked at more than two jobs in 1992/1993/1994, please ask for additional pages to record the information for these additional jobs. After you have completed recording all jobs that you worked from January 1, 1992 to the present, continue to $Q 13$.

\section{Section 3. Effects on Employment of DUI Arrest/Loss of License}

Q13. Were you employed at the time of your most recent DUI arrest?
1. Yes
2. No [If No, SKIP to Q21 on PAGE 6.J

IF YOU HELD MORE THAN ONE JOB AT THE TIME OF YOUR DUI ARREST, PLEASE ANSWER THE FOLLOWING FOR THE JOB FROM WHICH YOU HAD THE MOST INCOME.

Q14. On a scale from 1 to 5 , how would you rate your overall satisfaction with the job you held at the time of your most recent DUI arrest?

Very Dissatisfied $1 \ldots \ldots . . \ldots . .3 \ldots . . .4 \ldots . .5$ Very Satisfied [CIRCLE A NUMBER FROM 1 TO 5.]

Q15. Were you self-employed at the time of your DUI arrest?
1. Yes [If Yes, SKIP to Q19.]
2. No

Q16. Does/did your employer know about your DUI arrest?
1. Yes
2. No [If No, SKIP to Q18.]

Q17. How did your employer find out about your DUI arrest? [CIRCLE THE BEST ANSWER.]

1. I told my employer.

2. A co-worker told my employer.

3. My employer read about it in the newspaper.

4. The Department of Motor Vehicles notified my employer.

5. Other (Please specify:

Q18. Does/did your employer (at the time of your DUI arrest) know that you lost your license?
1. Yes
2. No
3. I have not yet lost my license

Q19. On a scale from 1 to 5 , to what extent has your income been reduced as a direct result of your DUI arrest or loss of license?

Not at All 1.....2.....3.....4.....5 Very Much [CIRCLE A NUMBER FROM 1 TO 5.]

Q20. [SKIP to Q21 IF YOU ANSWERED "Not at All" to Q19.] How much was your income reduced as a direct result of your DUI arrest or loss of license (\$/week)? 


\section{Section 4. Experiences With DUI Arrest and Loss of License}

Q21. What vehicle were you driving at the time of your most recent DUI arrest?
a. Year:
b. Make:

Q22. In whose name was the vehicle you were driving at the time of your most recent DUI arrest registered? [CIRCLE THE MOST APPROPRIATE ANSWER.]
1. My own name
4. Friend (living in same household)
2. Spouse
5. Friend (not living in same household)
3. Relative (other than spouse)
6. Prior Owner
7. Other (please specify:

Q23. Were you wearing your seat belt at the time of your DUI arrest?
1. Yes
2. No

Q24. What did the police say was the reason for stopping your vehicle when the DUI arrest was made? [CIRCLE THE MOST APPROPRIATE ANSWER.]

1. Accident

2. Erratic/reckless driving (e.g., weaving)

3. Speeding

4. Other moving traffic violation (e.g., failure to stop at red light, improper turning)

5. Vehicle violation (e.g., expired inspection sticker, tail light out, no headlights)

6. Roadblock or sobriety checkpoint

7. Other (Please specify:

Q25. How frequently in the year before your most recent DUI arrest did you consume 1-2 beers/mixed drinks/glasses wine less than 1 hour before driving? [CIRCLE THE MOST APPROPRIATE ANSWER.]
1. Never
2. Once in a while
3. More than once per week
4. Daily

Q26. How frequently in the year before your most recent DUI arrest did you consume 3 beers/mixed drinks/glasses wine less than 1 hour before driving? [CIRCLE THE MOST APPROPRIATE ANSWER.]
1. Never
2. Once in a while
3. More than once per week
4. Daily 
$>>>>$ IF YOU HAVE NOT YET LOST YOUR LICENSE BECAUSE OF YOUR MOST RECENT DUI ARREST, PLEASE SKIP TO Q41 ON PAGE 9. $<<<<$

Q27. Did you take a breath test at the time of your most recent DUI arrest?
1. Yes [f Yes, SKIP to Q29.]
2. No

Q28. Were you charged with refusing a breath test?
1. Yes
2. No

Q29. Before your most recent DUI arrest, did you know you could lose your license for failing or refusing a breath test, even if you were NOT convicted of a DUI offense in court?
1. Yes
2. No

Q30. Did you request an administrative hearing with the Department of Motor Vehicles when you lost your license to get your license back?
1. Yes
2. No [f No, SKIP to Q34.]

Q31. Did you attend the administrative hearing?
1. Yes
2. No

Q32. Did the arresting police attend the administrative hearing?
1. Yes
2. No

Q33. What was the result of the administrative hearing?

1. I lost my license 2. I got my license back [f license returned, SKIP to Q41 on PAGE 9.]

Q34. When did your most recent DUI license suspension/revocation officially BEGIN?

$\frac{1}{\text { (Month) }} \frac{}{\text { (Year) }}$

Q35. How long will (or did) this most recent DUI license suspension/revocation last?

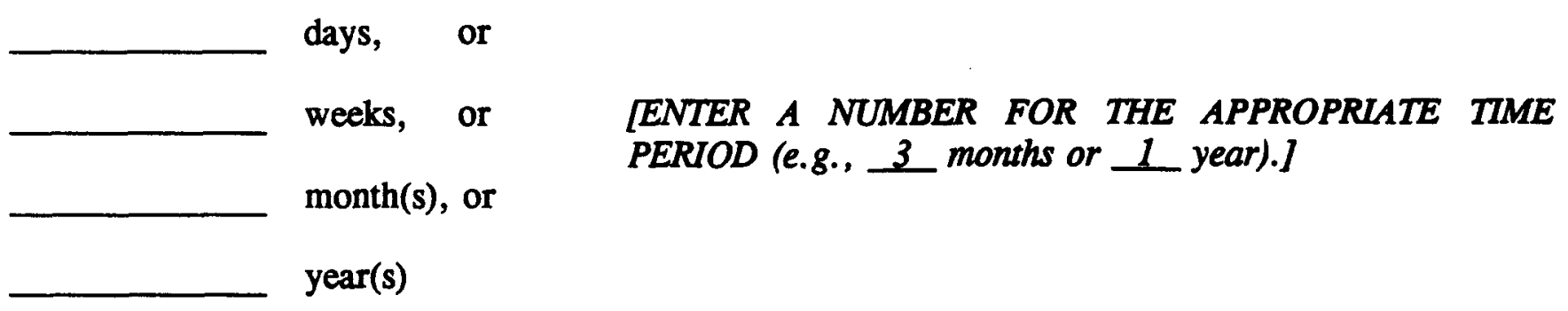




\section{STUDY OF EFFECTS OF LICENSE REVOCATION ON EMPLOYMENT - 1994 \\ Questionnaire for ALR States - Final Version 6}

Q36. On a scale from 1 to 5 , how likely is it that you will (or did) get your license when your suspension/revocation ends (or ended)?

Not at all Likely $1 \ldots . . .2 \ldots . .3 \ldots . . .4 \ldots . .5$ Very Likely [CIRCLE A NUMBER FROM 1 TO 5.]

Q37. How likely is it that you will drive while you don't have a license?

Not at all Likely $1 \ldots \ldots . \ldots . . . . . . .4 \ldots . . .5$ Very Likely [CIRCLE A NUMBER FROM 1 TO 5.]

Q38. [SKIP to Q39 IF YOU ANSWERED "Not at all Likely" to Q37.] Considering how you drive when you don't have a license, how likely is it that you will be caught during one month?

Not at all Likely $1 \ldots \ldots . . \ldots . .3 \ldots . . .4 \ldots . .5$ Very Likely [CIRCLE A NUMBER FROM 1 TO 5.]

Q39. On a scale from 0 to 5, to what extent has your loss of license interfered with the following? [CIRCLE A NUMBER FROM 0 TO 5 FOR EACH ACTIVITY.]

\begin{tabular}{|c|c|c|}
\hline $\begin{array}{c}\text { Not } \\
\text { Applicable }\end{array}$ & $\begin{array}{l}\text { Not } \\
\text { at All }\end{array}$ & Somewhat \\
\hline
\end{tabular}
a. Work
$0 \ldots \ldots \ldots \ldots . . .1$
3.
$.4 \ldots \ldots \ldots \ldots . .5$
b. Social/recreational activities
$0 \ldots \ldots \ldots \ldots . . .1$
2.
3.
$.4 \ldots \ldots \ldots \ldots . .5$
c. Shopping
$0 \ldots \ldots \ldots \ldots . . . . . \ldots \ldots \ldots . .2$
3.
$.4 \ldots \ldots \ldots \ldots . . .5$
d. Medical appointments
$0 \ldots \ldots \ldots \ldots . .1$
2.
3.
4............5
e. Religious services/activities
$0, \ldots \ldots \ldots \ldots \ldots . . \ldots \ldots \ldots . .2$
3 .
$.4 \ldots \ldots \ldots \ldots . .5$

Q40. Since you lost your license, what transportation arrangements do you use frequently for the following? [CIRCLE ALL NUMBERS THAT APPLY FOR EACH ACTIVTYY.]

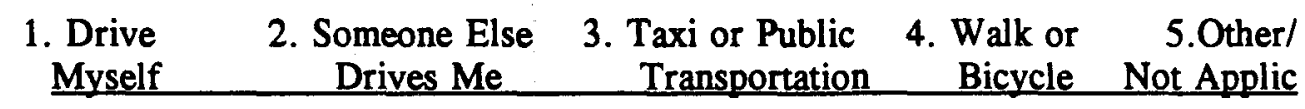
a. Work
1.
...2.
4 .
b. Social/recreational
$1 \ldots . . . . . . . . . . . . . .2 .2$
4. .5 activities
c. Shopping
1.
2
3
4. .5
d. Medical appointments
$1 \ldots \ldots \ldots \ldots \ldots \ldots . . .2$
3.
$.4 \ldots \ldots \ldots \ldots \ldots . . .5$
e. Religious services/
$1 \ldots \ldots \ldots \ldots \ldots \ldots . .2$
4. activities
f. How did you get here today?
g. How did you get to work 1 on the last day you worked? 


\section{Section 5. Background Information}

Q41. On average, how many miles do you drive per year when you have a full license to drive? miles/year (average)

Q42. How many miles did you drive last week?

\section{miles last week}

Q43. In which of the following ethnic groups would you classify yourself? [CIRCLE ONE.]

1. White, not of Hispanic Origin

2. African-American, not of Hispanic Origin
3. Hispanic

4. Native American

5. Asian/Pacific Islander

Q44. What is your date of birth (month and year)?

$\frac{}{\text { (Month) }} \frac{}{\text { (Year) }}$

Q45. What is your highest level of education? [CIRCLE ONE.]

1. Junior high school (or less)

2. Some high school

3. High school graduate

4. Trade school certificate
5. Some college, but no degree

6. Associates or 2-year college degree

7. Bachelors or 4-year college degree

8. Masters or doctorate degree

Q46. What is your gender? [CIRCLE ONE.]
1. Male
2. Female

Q47. What is your current marital status? [CIRCLE ONE.]
1. Single
3. Divorced
2. Married
4. Separated
5. Widowed

Q48. Other than yourself, how many people live in your household who currently have a valid driver's license? other people in my household currently have a valid driver's license.

Q49. Other than yourself, how many people live in your household who are currently employed? other people in my household are currently employed.

Q50. If you answered "O" to Q49, SKIP Q50.J What is the combined weekly gross earnings (before taxes and withholdings) of these other people who live in your household who are currently employed? 


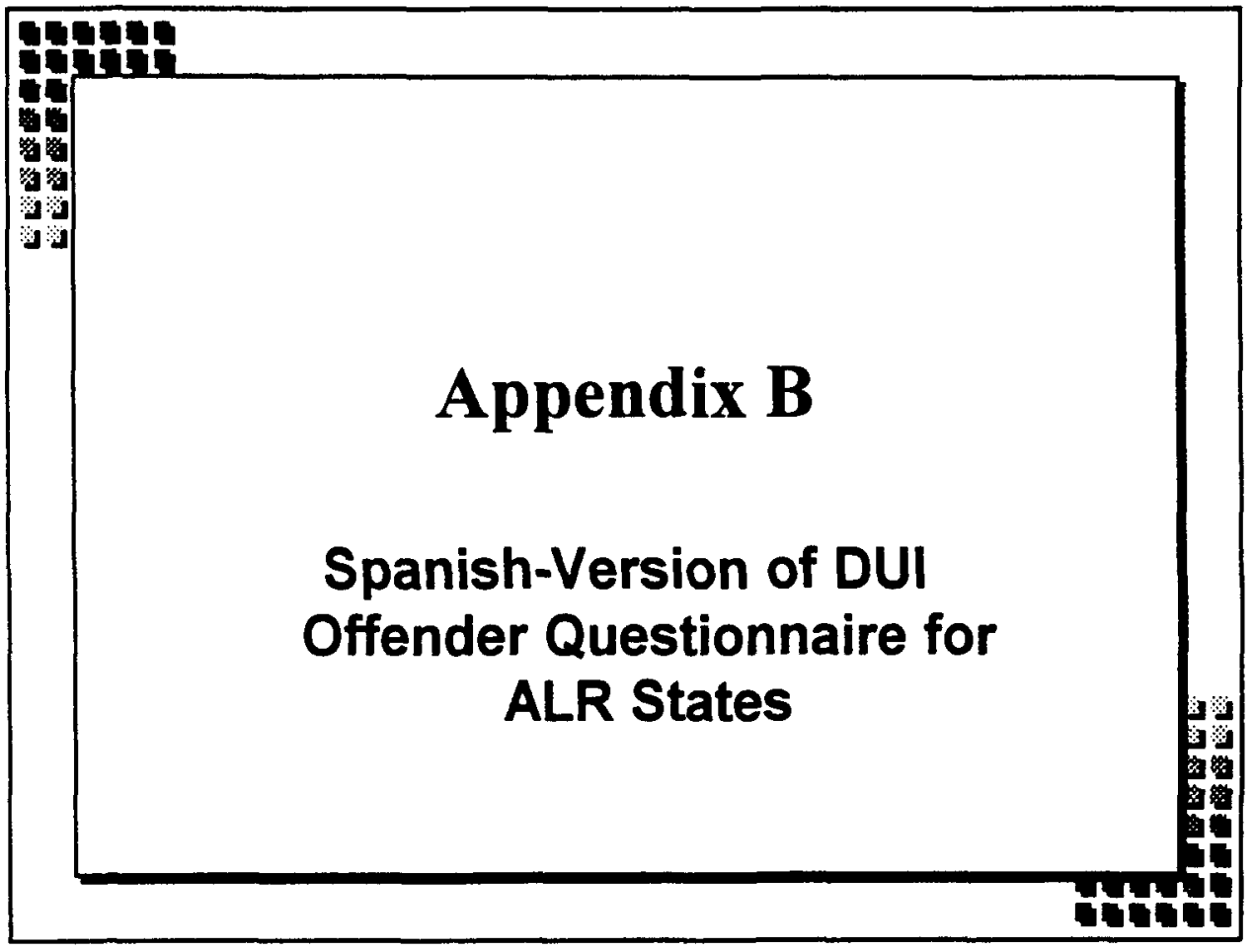


Tenemos interés en descubrir como su arresto reciente por manejar (guiar) bajo la influencia del alcohol (MI) o manejar ebrio (ME) ha afectado su vida, especialmente su empleo. En esta encuesta, este arresto se llama "su arresto (ME) más reciente." Los resultados de esta investigación anónima van a ser utilizados para proponer recomendaciones respecto (ME) y las leyes estatales. Muchas gracias por su contribucion a este estudio.

\section{Sección 1. Introducción}

P1. ¿Cuál de los siguientes elementos describe mejor la razón por su asistencia en el programa de hoy? [FAVOR DE PONER UN CÍRCULO EN LA RESPUESTA MÁS APROPRIADA.]

1. Arresto por (MI/ME)

2. Voluntario a si mismo

3. Referido por un programa de asistencia para empleados

4. Otra razón (favor dedecir:

> > > SI NO ESTA AQUÍ HOY POR RAZÓN DE UN ARRESTO POR (MI/ME), FAVOR DE PASAR A P41 EN PAGINA 9. $<<<<$

P2. ¿En que condado y estado vive ud. hoy?

Condado:

Estado:

P3. ¿Qué era la fecha (mes y año) y la localidad de su arresto más reciente (el que ha resultado en su presencia en este programa)?

$\frac{1}{\text { (Mes) }} \frac{}{\text { (Año) }}-\frac{}{\text { (Localidad: Ciudad/pueblo/municipio, estado) }}$

P4. ¿Tuvo ud. la licencia de manejar al tiempo de su arresto (ME) más reciente?
1. Si
2. No [Si No, PASE a P6.]

P5. ¿Cuándo perdió su licencia al principio por este arresto (ME) más reciente (mes y año)?

$\begin{array}{ll}\text { (Mes) } & \text { O } \\ \text { (Año) } & \begin{array}{l}\text { No he perdido la licencia ni empezado la suspención. } \\ \text { [FAVOR DE PONER UN CÍRCULO EN ESTA LÍNEA SI } \\ \text { APROPRIADO.] }\end{array}\end{array}$

P6. ¿Fué este arresto (ME) más reciente su PRIMER arresto (ME) desde que empezo a manejar (guiar)?
1. Si [SI ES EL PRIMER ARRESTO (ME, PASE A P9.]
2. No

P7. ¿Cuántos (ME) en total (incluso éste más reciente) ha tenido ud. en este año pasado?

P8. ¿Cuántos arrestos (ME) en total (incluso éste más reciente ha tenido ud. en los ultimos 5 años? 


\section{Sección 2. Empleo, Instrucción, Busca de Empleo, y Períodos \\ Sin Trabajo en 1992/1993/1994}

P9. ¿Quisiéramos que ud. nos dijera (segun su capacidad) acerca de su empleo desde el 1 de enero 1992 hasta el presente. En el calendario mensual 1992/1993/1994 abajo, ponga por favor el número de la siguiente lista (1-7) en cada bloque para indicar su actividad ese mes Si mas que un actividad aplica por un mes, ponga los números para todos la actividades aplicable por cada mes. Escoge de estas 7 categorias:

1. Empleo (cualquier actividad de que la recibio ingresos incluso empleo de tiempo pleno, trabajo por horas, empleo de si mismo, y servicio militar

2. Asistencia a la escuela (colegio, universidad, instituto vocacional)

3. Desempleo, mientras buscaba trabajo

4. Sin empleo por su elección (no buscaba trabajo)

5. Incapacidad

6. Retiro

7. Cárcel

Favor de poner un número por lo menos (de 1-7) para cada mes abajo:

\begin{tabular}{||l||l|l|l|l|l|l|l|l|l|l|l|l||}
\hline & ene & feb & mar & abril & may & jun & jul & ago & sept & oct & nov & dic \\
\hline \hline 1992 & & & & & & & & & & & & \\
\hline 1993 & & & & & & & & & & & & \\
\hline 1994 & & & & & & & & & & & & \\
\hline
\end{tabular}

Si no indicó "1" (empleo) para ningún mes arriba, FAVOR DE PASAR A P21 EN PÁGINA 6.

P10. ¿Qué cambios sucedieron en su empleo e ingresos debido a su arresto (ME) y/o la pérdida de licencia? [SI NECESITA MÁS ESPACIO, FAVOR DE ESCRIBIR AL REVES DE ESTA PÁGINA.]

Ahora queremos que ud. nos provee más información en las proximas páginas para todos los trabajos que ud. tuvo desde el 1 de enero 1992 hasta el presente (trabajos que corresponden a todo los "1s" en el calendario mensual arriba). Favor de seguir con estas instrucciones adicionales:

1. Ponga los períodos de cubertura parcial si es apropriado. Por ejemplo si mantuvo dos trabajos de tiempo parcial, provee información alredor de ambos trabajos.

2. Si ud. cambio trabajos mientras trabajaba por el mismo patrón durante 1992, 1993, o 1994, favor de proveer información de los dos trabajos por separado. 
Favor de responder a las siguiente preguntas para su trabajo actual (o trabajo mas reciente si no esta empleado).

P11a. ¿Cuándo comenzó su trabajo actual (o el trabajo más reciente si no esta trabajando ahora)?

Mes: Año: 19

P1lb. ¿Cuándo termino el trabajo referido en P11a?

Mes: Año: 19

O Estoy empleado todavía en este trabajo.

P1lc. ¿Cuál de los siguientes mejor representa la industria o el dueño de su trabajo actual (o el trabajo más reciente si no tiene trabajo)? [PONGA UN CIRCULO EN EL NÚMERO APROPRIADO]
1. Agricultura
5. Transportación
9. Finanzas/seguros/propiedades
2. Mineria
6. Servicios municipios
10. Industria de servicios
3. Construcción
7. Ventas al por mayor
4. Fabricación
8. Comercio al por menor
11. Gobierno local/estatal
12. Gobierno federal

13. Militario

14. Otro (favor de indicar:

P11d. ¿Cuál de los siguiente describe mejor el tipo de trabajo que tiene ud. ahora (o en el trabajo más reciente si no tiene trabajo ahora)? [FAVOR DE PONER UN CÍRCULO EN LA RESPUESTA APROPRLADA]
1. Profesional
4. Ventas: Alto Nivel
7. Servicios (oje., productos de comida)
10. Chofer
2. Técnico
5. Ventas: Dependiente
8. Artesano
Profesional
3. Administración
6. Oficinista
9. Maquinista
11. Obrero
12. Otro (favor de decir:

Plle. ¿Qué distancia maneja para su trabajo actual? O sea, ¿qué es/era el promedio distancia, en una dirreción de su vaje diario desde la casa al lugar de trabajo?

millas en una dirreción promedio

P11f. ¿Cómo describiría su necesidad de manejar (guiar) para su trabajo actual (o trabajo mas reciente)? [PONGA CIRCULOS EN TODOS QUE APPLICAN.]

1. No es necesario manojar para hacer mi trabajo.

2. Uso mi vehículo solamente para viajar al trabajo.

3. Es necesario manejar mi vehículo en el trabajo de vez en cuando.

4. Es necesario manejar mi vehículo como parte de mi trabajo cada dia.

5. Manejo otro vehiculo en mi trabajo de ver en cuando.

6. Manejo otro vehículo en mi trabajo cada día.

P11g. En una semana típica, ¿cuántas horas trabaja/trabajaba en su trabajo actual (o trabajo mas reciente)? horas/semana (promedio)

P11h. En una semana típica, ¿que son/eran sus sueldos brutos en su trabajo actual (o trabajo mas reciente)? $\$$ /semana ingresos brutos promedio (antes de impuestos o retenciones)

P11i. Si es que ya no tiene este trabajo, ¿por qué lo dejo? [PONGA UN ClRCULO EN UN NÚMERO.]

1. Mejor oportunidad

2. Me despidieron

3. Razón médica/incapacidad

4. Pérdida de licencia, ME

5. Mudanza

6. Dejé mi trabajo/insatisfecho con las condiciones de trabajo

7. Regresar al escuela

8. Trabajo temporario se terminó 
Favor de dar respuestas para las siguientes preguntas en relacion del trabajo que tuvo antes del trabajo referido en la página antes.

P12a. (PASE A P13 SI NO TUVO TRABAJO ANTES) ¿Cuándo comenzo el trabajo anterior del más reciente?

Mes: Año: 19

P12b. ¿Cuándo terminó el empleo en el trabajo anterior del más reciente?

Mes: Año: 19

- Todavía estoy empleado con este trabajo.

P12c. ¿Cuál de los siguientes elementos representa mejor la industria o dueño del trabajo anterior del más reciente? [PONGA CIRCULO EN LA RESPUESTA APROPRLADA.]
1. Agricultura
5. Transportación
9. Finanza/seguros/propiedades
2. Minería
6. Servicios municipios
10. Industria de servicios
3. Construcción
7. Comercio al por mayor
11. Gobierno local/estatal
4. Fabricación
8. Ventas al por menor
12. Gobierno federal
13. Militario

14. Otro: (favor de explicar:

P12d. ¿Cuál de los siguientes elementos mejor describe el tipo de trabajo que hizo en el trabajo anterior del más reciente? [PONGA CIRCULO EN LA RESPUESTA APROPRLADA.]
1. Profesional
4. Ventas: Nivel Alto
7. Servicios (eje. productos de comida
10. Chofer
2. Técnico
5. Ventas: Dependiente
8. Artesano
3. Administración
6. Oficinista
9. Maquinista Profesional
12. Otro (favor de explicar:
11. Obrero

P12e. ¿Para este trabajo anterior del más reciente, ¿qué es/era el promedio de distancia, en una dirección en su viaje diario de la casa al lugar de trabajo?

millas en una dirección (promedio)

P12f. ¿Cómo describiría su necesidad de manejar (guiar) en este trabajo anterior del más reciente? [PONGA UN CIRCULO EN TODOS QUE APLICAN.]

1. No es necesario manejar para hacer mi trabajo.

2. Uso mi vehículo solamente para viajar al trabajo.

3. Es necesario manejar mi vehículo en el trabajo de ver en cuando.

4. Es necesario manejar mi vehículo como parte do mi trabajo cada día.

5. Manejo otro vehículo en mi trabajo de ver en cuando.

6. Manejo otro vehículo on mi trabajo cada día.

P12g. En una semana típica, ¿cuántas horas trabajaba en este trabajo anterior del más reciente? horas/semana (promedio)

P12h. En una semana típica, ¿qué era sus sueldos brutos en este trabajo anterior del más reciente? $\$$ /semana ingresos brutos promedio (antes de impuestos o retenciones)

P12i. Si es que ya no tiene este trabajo, ipor qué lo dejó? [PONGA UN CfRCULO EN UNO.]

1. Mejor oportunidad

2. Me despidieron

3. Razón médica/incapacidad

4. Pérdida de licencia, ME

5. Mudanza

6. Dejé mi trabajo/insatisfecho con las condiciones de trabajo
7. Regresar al escuela

8. Trabajo temporario se torminó 
ESTUDIO DEL IMPACTO DE REVOCACIÓN DE LICENCIA EN EL EMPLEO-1994

Cuestionario para estados con ALR - Versión 6 Final

Si ud. tuvo más que dos trabajos en 1992/1993/1994, favor de pedimos más páginas para reportar la información de estos otros trabajos. Después de completar recordando todos los trabajos que tuvo desde el 1 de enero 1992 hasta el presente, continúe con P13.

Sección 3. Impactos en el Empleo del Arresto (ME)/Pérdida de Licencia

P13. Estaba ud. empleado cuando fue arrestado por ME?

1. Si

2. No [Si No, pase a P21 en PÁGINA 6.]

SI UD. TUVO MÁS QUE UN TRABAJO EN EL MOMENTO DE SU ARRESTO POR ME, FAVOR DE RESPONDER A LOS SIGUIENTES ELEMENTOS PARA EL TRABAJO DEL LO CUAL RECIBĹA MÁS INGRESOS.

P14. En una escala de 1 a 5 , ¿como evaluaría su satisfacción en general con el trabajo que tuvo en el momento de su arresto (ME) más reciente?

Muy Disfatisfecho $1 \ldots . .2 \ldots . .3 \ldots 4 \ldots . .5$ Muy Satisfecho [PONGA UN CÍRCULO EN UN NÚMERO.]

P15. ¿Estaba ud. empleado por si mismo en el tiempo de su arresto (ME)?
1. Si [Si St, PASE a P19.]
2. No

P16. ¿Supo/sabe su patrón de su arresto (ME)?
1. Si
2. No [Si No, PASE a P18.]

P17. ¿Cómo supo o discrubió su patrón de su arresto (ME)? [PONGA UN CÍRCULO EN EL MEJOR RESPUESTA.]

1. Yo le dije a mi patrón.

2. Un compañero de trabajo le dijo a mi patrón.

3. Mi patrón lo leyó en el perídico.

4. El Departamento de Vehículos Automotrices lo teporto al patrón.

5. Otro (Favor de explicar:

P18. ¿Supo/sabe su patrón que ud. perdió la licencia cuando lo arrestaron por ME?
1. SI
2. No
3. No he perdido la licencia todavía.

P19. En una escale de 1 a 5 , ¿hásta que grado ha sido reducido su ingresos por causa directa del arresto (ME) o la pérdida de la licencia?

Nada 1......2.................5 Muchísimo [PONGA UN CÍRCULO UN UN NÚMERO 1 A 5.]

P20. [PASE a P21 SI RESPONDIÓ "NADA" A P19.] ¿Por cuanto fue reducido sus ingresos por causa directa de su arresto (ME) o pérdida de la licencia? (\$/semana)?

$\$$ /semana ingresos reducidos por causa directa de mi arresto (ME) o pérdida de licencia 


\section{Sección 4. Experiencias Con Arresto ME y Perdida de Licencia}

P21. ¿Qué tipo de vehŕculo manejaba al momento de su arresto (ME) más reciente?
a. Año:
b. Marca:

P22. ¿En el nombre de quien estaba registrado el vehículo que estaba manejando cuando lo arrestaron por ME? [PONGA UN CÍRCULO EN LA RESPUESTA APROPRIADA.]
1. El nombre mio
4. Amigo (viviendo en mi casa)
2. Conyuge
5. Amigo (no viviendo en mi casa)
3. Pariente (no cónyuge)
6. El duễo anterior

7. Otro (favor de decir:

P23. ¿Estaba ud. usando el cinturón de seguridad cuando lo arrestaron por ME?
1. Si
2. No

P24. ¿Qué fue la razón que el policia le dí por haberle detenido cuando le arrestaron por ME? [PONGA UN CÍRCULO EN LA RESPUESTA MÁS APROPRIADA.]
1. Accidente
2. Manejando irregularmente (eje., zigzagueando)
3. Velocidad excesiva
4. Otra violación de tráfico (eje., falta de parar en semáforo con señal roja.)
5. Violación de vehículo (eje., inspección vencida)
6. Barricada (o inspeccion) policiaca
7. Otro (Favor de explicar:

P25. ¿Cón que frecuencia en el año antes de su arresto (ME) más reciente ud. consumió 1-2 cervezas/bebidas/copas de vino en una hora o menos antes de manejar? [PONGA UN CÍRCULO EN LA RESPUESTA MÁS APROPRIADA.]
1. Nunca
2. De vez en cuando
3. Más que una vez por semana
4. Diariamente

P26. ¿Con que frecuencia en el año antes de su arresto (ME) más reciente ud. consumí́ 3 cervezas/bebidas/copas de vino en una hora o menos antes de manejar? [PONGA UN CÍRCULO EN LA RESPUESTA MAS APROPRIADA.]
1. Nunca
2. De vez en cuando
3. Más que una vez por semana
4. Diariamente 
$>>>>$ SI UD. NO HA PERDIDO SU LICENCIA POR RAZÓN DE SU ARRESTO (ME) MÁS RECIENTE, FAVOR DE PASAR A P4I EN PÁGINA 9. $<<<~$

P27. ¿Tomó ud. el examen de aliento en su arresto (ME) más reciente?
1. Sí [Si St, PASE A P29.]
2. No

P28. ¿Lo acusaron por rehusar el examen de aliento?
1. S1
2. No

P29. Antes de su arresto (ME) más reciente, ¿sabra ud. que pudiera perdir la licencia por falta de tomar o por rehusar el examen de aliento, aunque no lo hubieran encontrado culpable por $\mathrm{ME}$ en la corte?
1. $\mathrm{S} 1$
2. No

P30. ¿Pidió ud. una audencia (vista) administrativa con el Departamento de Vehículo Automotrices para que se devolvieran la licencia?
1. $S 1$
2. No [Si No, PASE A P34.]

P31. ¿Asistió ud. a la audencia administrativa?
1. S1
2. No

P32. ¿El agente de poliça que lo arrestó también asistió a la audencia?
1. Si
2. No

P33. ¿Qué fue el resultado de la audencia administrativa?

1. Perdí la licencia 2. Me devolvieron la licencia [Si elegio número 2, PASE a P41 en PAGINA 9.]

P34. ¿Cuándo se comenz6 oficialmente la suspensión/revocación ME de su licencia?

$\frac{1}{\text { (Mes) }} \frac{}{\text { (Año) }}$

P35. ¿Cuánto tiempo va durar (o duró) esta suspensión/revicacuón por su arresto (ME) más reciente?

$\begin{array}{llll}\text { días, } & 0 & \\ \text { semanas, } & 0 \quad \begin{array}{l}\text { [PONGA UN NUMERO PARA LA APROPRIADO } \\ \text { mes(es), }\end{array} \\ & \text { años(s) }\end{array}$




\section{ESTUDIO DEL IMPACTO DE REVOCACIÓN DE LICENCIA EN EL EMPLEO-1994}

Cuestionario para estados con ALR - Versión 6 Final

P36. En una escala de 1 a 5, ¿qué es (o era) la probabilidad que van a devolver su licencia cuando se termina(6) la suspension/ revocación?

No es probable 1 ....2.........4....5 Muy probable [PONGA UN CIRCULO EN UN NÚMERO I A 5.]

P37. ¿Qué es la probabilidad que ud. todavía va manejar aunque no tenga la licencia?

No es probable 1 ....2....3....4....5 Muy probable [PONGA UN CIRCULO EN UN NÚMERO 1 A 5.]

P38. [SI RESPONDIÓ A P37 CON "NO ES PROBABLE" PASE A Q37.] Consideranndo su modo de manejar cuando no tiene la licencia, ¿qué es la probabilidad que la polićáa lo van a capturar durante un mes?

No es probable 1 .....2....3....4....5 Muy probable [PONGA UN CIRCULO EN UN NÚMERO 1 A 5.]

P39. En una escala de 0 a 5 , ¿hasta que punto la pérdida de licencia ha estorbarado los siguiente actividades? [PONGA UN CÍRCULO EN UN NÚMERO 0 A 5 PARA CADA ACTIVIDAD.]

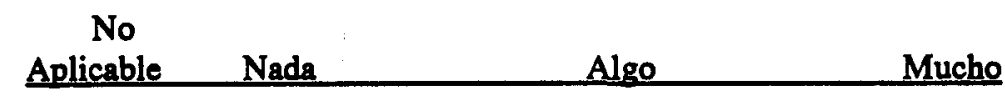
a. Trabajo
0.
.2 .
.3.
...............5
b. Actividades sociales
$0 \ldots \ldots \ldots \ldots . . . . . . . \ldots \ldots . . .2$
.3.
...............
c. Compras
$0 \ldots \ldots \ldots \ldots . . . \ldots \ldots \ldots . . . .2$
3.
$. .4 \ldots \ldots \ldots \ldots . . .5$
d. Consultas médicas
0..
.2.
.3.
4.............
e. Actividades religiosos

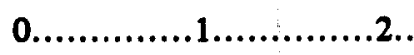
..3.
..............

P40. Desde que perdió la licencia, ¿qué modo de transportación usa con frecuencia para los siguientes actividades [PONGA UN CÍRCULO EN TODOS LOS NÚMEROS QUE APLICAN.]

1. Yo mismo 2. Otra persona 3. Taxi o Trans- 4. Caminar o 5.Otro/ Maneio Maneis portación Pública bicicleta No Aplica
a. Trabajo

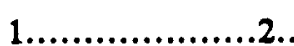 3.
$4 \ldots \ldots \ldots \ldots \ldots . . . .5$
b. Actividas sociales/
$1 .$.

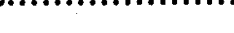
$4 \ldots \ldots . . . . . . . . .5$ recreactivas
c. Compras
1.
.2.
4 .5
d. Consultas médicas

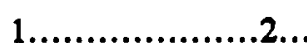
..3.
4. .5
e. Servicios/actividades
$1 .$.
2.
4.. . .5 religiosas
f. ¿Cómo vino ud. aqui hoy?

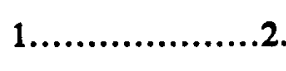

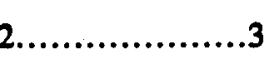

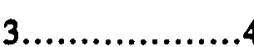
$4 \ldots \ldots \ldots \ldots \ldots . . .5$
g. ¿Cómo llegó al trabajo el último día que trabajo?

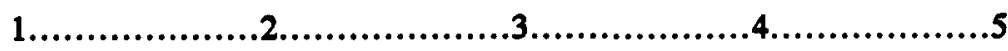


Sección 5. Información Antecedente

P41. En promedio, ¿cuántas millas maneja al año cuando tiene la licencia de manejar? millas/año (promedio)

P42. ¿Cuántas millas manejo la semana pasada? millas la semana pasada

P43. ¿En cuál de los siguientes grupos étnicos se clasificaría? [PONGA UN CÍRCULO EN UNO.]

1. Anglosajón, no Hispano

2. Africano-Americano, no Hispano

3. Hispano
4. Indio/Nativo Americano

5. Asiático/Isleño del Paćfico

P44. ¿Qué es la fecha de su nacimiento (mes y año)?

(Mes) $' \frac{}{\text { (Año) }}$

P45. ¿Cuál es su nivel de educación [PONGA UN CÍRCULO EN UNO.]
1. 8 años o menos
2. Algo de la secundaria
3. Graduado de la secundaria
4. Certificado vocacional
5. Algo de universidad, sin título
6. Tínulo asociado (2 años)
7. Bachiller (4 años)
8. Maestria o el doctorado

P46. ¿Cuál es su género (sexo)? [PONGA UN Cf́RCULO EN UNO.]
1. Varón
2. Hembra

P47. ¿Cuál es su estado matrimonial? [PONGA UN CÍRCULO UN UNO.]
1. Soltero
3. Divorciado
5. Viudo(a)
2. Casado
4. Separado

P48. Aparte de ud., ¿cuántas personas en la casa donde vive actualmente tienen una valida licencia de manejar?

otra gente in mi casa con licencia valida.

P49. Aparte de ud., ¿cuántas personas en la casa donde vive actualmente están empleados? personas otras en mi casa actualmente empleados

P50. [Si ud. respondio "O" a P49, No hay que responder a P50.] Todo combinado, ique son los ingresos brutos (antes de impuestos y retenciones) de estas otras personas en la casa donde vive que estan empleados actualmente?

$\$$ /semana, ingresos brutos de otra gente en mi casa actualmente empleados

MUCHAS GRACIAS POR SU PARTICIPACION EN NUESTRA INVESTIGACIÓN. 


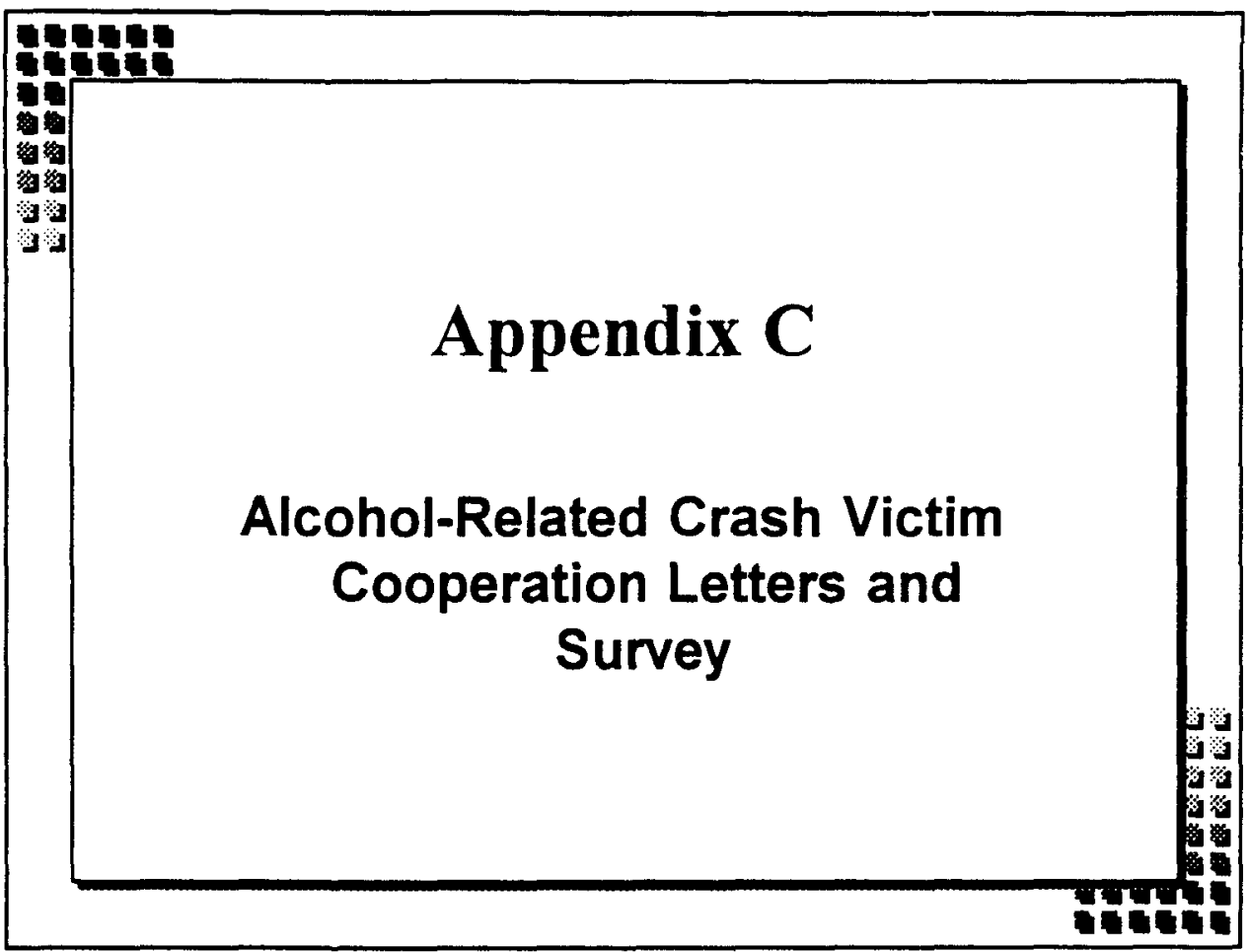


February 10, 1995

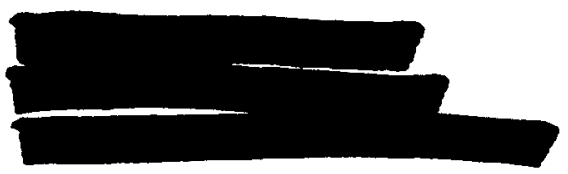

\section{Dear}

We are cooperating in a study to learn more about the impact of alcohol-related accidents on their victims. Our records indicate that you were recently a victin of such an accident, and we would appreciate your participating in the study by completing the enclosed short questionnaire and returning it in the postpaid envelope to KETRON, the contractor who will be analyzing the results of the survey.

This is an anonymous study. There is no place on the questionnaire for your name or other identifier. We have not given your name and address to anyone, and your participation in the study is completely voluntary. However, we hope you will cooperate so that national policy can be informed by the experience of victims.

Should you have any questions about completing the survey, please feel free to call KETRON toll-free at (800) 982-7645 and ask for assistance with the accident victim survey.

Thank you in advance for your participation.

Sincerely,

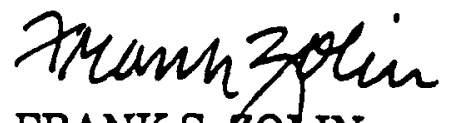

FRANK S. ZOLIN

Director

Enclosure 


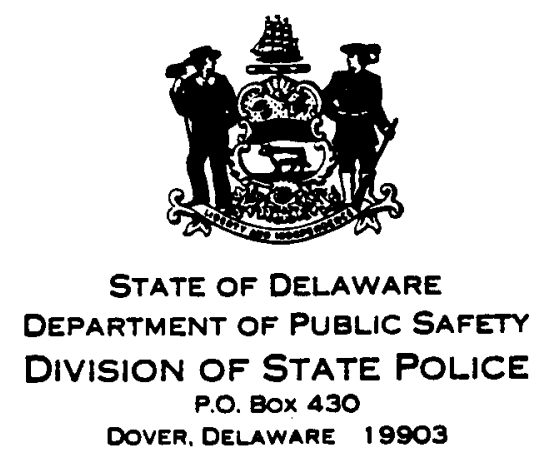

February 20, 1995

\section{Dear Delaware Motorist:}

We are cooperating in a study to leam more about the impact of alcohol-related accidents on their victims. Our records indicate that you were recently a victim of such an accident, and we would appreciate your participating in the study by completing the enclosed short questionnaire and returning it in the postpaid envelope to KETRON, the contractor who will be analyzing the results of the survey.

This is an anonymous study. There is no place on the questionnaire for your name or other identifier. We have not given your name and address to anyone, and your participation in the study is completely voluntary. However, we hope you will cooperate so that national policy can be informed by the experience of victims.

Should you have any questions about completing the survey, please feel free to call KETRON toll-free at (800) $982-7645$ and ask for assistance with the accident victim survey.

Thank you in advance for your participation.

Very truly yours,

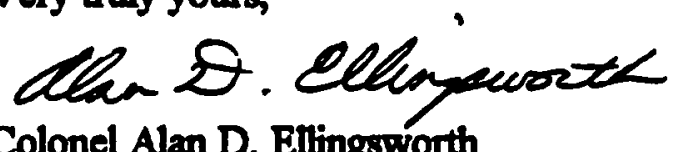

Colonel Alan D. Ellingsworth

Superintendent 
Anthony A. Sarcione

District Attorney
DISTRICT ATTORNEY'S OFFICE OF CHESTER COUNTY

17 NORTH CHURCH STREET, SUITE 218

COURTHOUSE ANNEX

WEST CHESTER, PENNSYLVANIA 19380-3086

TELEPHONE: $610-344-6801$

FAX: 610-344-5905
Charles Zagorskie

Chief County Detective

April 19, 1995

We are cooperating in a study to learn more about the impact of alcohol-related accidents on their victims. Our records indicate that you were a victim of such an accident within the last 2 years. You may have been a driver or a passenger in a vehicle that was struck by a drunk driver or your parked vehicle could have been damaged by a drunk driver. We would appreciate your participating in the study by completing the enclosed short questionnaire and returning it in the postpaid envelope to KETRON, the local contractor who will be analyzing the results of the survey.

This is an anonymous study. There is no place on the questionnaire for your name or other identifier. Your participation in the study is completely voluntary. However, we hope you will cooperate so that national policy can be informed by the experience of victims.

Should you have any questions about completing the survey, please feel free to call KETRON at (610) 648-9000 or toll-free at (800) 982-7645 and ask for assistance with the accident victim survey. Thank you in advance for your participation.

Sincerely,

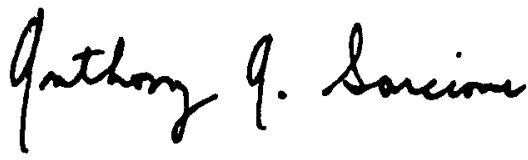

Anthony A. Sarcione District Attomey

Enclosure 
Q1. What was the date (month and year) of the alcohol-related accident in which you were involved?

(Month) $\frac{}{\text { (Year) }}$

Q2. Which of the following best describes the way you were involved in the accident? [CIRCLE ONE.]

1. I was the driver of a vehicle, and I was charged with DUI.

2. I was a passenger in the vehicle of a driver, who was charged with DUI.

3. I was the driver of another vehicle involved in the accident, and I was not charged with DUI.

4. I was a passenger in a vehicle involved in the accident, whose driver was not charged with DUI.

5. I was a pedestrian.

Q3. Which of the following best describes the injuries you received in the accident? [CIRCLE ONE.]

1. I was not injured in the accident.

2. I was injured, but I was not treated for my injuries at a hospital.

3. I was treated for my injuries at a hospital, but I did not stay overmight in the hospital.

4. I was treated for my injuries at a hospital, and I stayed in the hospital for less than 1 week.

5. I was treated for my injuries at a hospital, and I stayed in the hospital for more than 1 week.

Q4. Which of the following best describes the damage to the vehicle you regularly drive because of the accident? [CIRCLE ONE.]

1. I do not drive a vehicle on a regular basis.

2. I had no loss of use of the vehicle I regularly drive because of the accident.

3. The vehicle I regularly drive was damaged in the accident, but I was still able to drive the vehicle.

4. My vehicle was damaged in the accident such that I could not drive it away from the accident scene, but it has been.repaired.

5. My vehicle was damaged in the accident such that I could not drive it away from the accident scene, and it has not been repaired.

Q5. What changes took place in your employment and income because of your involvement in the alcoholrelated accident? 
Q6. We would now like you to tell us about your employment (to the best of your ability) from January 1st of 1993 to the present. On the following monthly 1993/1994/1995 calendar, please enter a number from the following list (1-6) in each month block to show your activity that month:

1. Employment (any activity from which you received income, including full-time employment, part-time employment, self employment, or military service)

2. School attendance (high school, college, or trade school)

3. Unemployment, during which time you were searching for a job

4. Not working of your own choice (i.e., you were NOT searching for a job)

5. Disability or hospitalization

6. Retirement

Please enter at least one number (from 1-6) in all applicable months below:

\begin{tabular}{||l|l|l|l|l|l|l|l|l|l|l|l|l||}
\hline \multicolumn{1}{l|}{} & Jan & Feb & Mar & April & May & June & July & Aug & Sept & Oct & Nov & Dec \\
\hline 1993 & & & & & & & & & & & & \\
\hline 1994 & & & & & & & & & & & & \\
\hline 1995 & & & & & & & & & & & &
\end{tabular}

If you did NOT enter a "1" (employment) in any month block above, SKIP TO Q11 ON PAGE 4.

We would now like you to provide some additional information for all jobs you held from January 1 , 1993 to the present (those jobs corresponding to all "1s" on the monthly calendar above). Enter overlapping time periods if appropriate. For example, if you held two part-time jobs at the same time, provide information on both jobs.

\section{PLEASE ANSWER THE FOLLOWING FOR YOUR CURRENT JOB (OR YOUR MOST RECENT JOB IF YOU ARE CURRENTLY NOT EMPLOYED).}

Q7a. When did you start work at your current job (or most recent job if you are currently NOT employed)?

Month: Year: 19

Q7b. When did you stop working at the job you referred to in Q7a?

Month: Year: 19

OR I am currently still employed at this job.

Q7c. Which of the following best describes the type of work you do at your current job (or most recent job if you are currently NOT employed)? [CIRCLE ONE.]

1. Professional

2. Technical

3. Managerial

4. Sales: High-Level

5. Sales: Clerical

6. Non-Sales: Clerical

12. Other (please specify:
7. Service (e.g., food service)

8. Craft/skilled worker

9. Machine operator

10. Professional driver

11. Laborer 
Q7d. In an average week, how many hours do/did you work at your current job (or most recent job)? hours/week (average)

Q7e. In an average week, what are/were your gross earnings at your current job (or most recent job)? $\$$ /week average gross earnings (before taxes or withholdings)

Q7f. If you are not still working at this job, why did you leave? [CIRCLE ONE.]
1. Better opportunity
5. Resignation/unsatisfactory job conditions
2. Layoff/termination
6. Return to school
3. Medical/disability
7. End of temporary job
4. Relocation
8. Retirement

SKIP TO Q9 IF YOU ONLY HELD ONE JOB IN 1993-1995. Otherwise, please answer the following questions for the job you held prior to or at the same time as the job you just described in $Q 7$. This second job is referred to as your "next most recent job" in the following questions. If you had more than 2 jobs in 1993-1995, please answer Questions Q8a through Q8f for each additional job on a separate piece of paper and enclose with your completed survey.

Q8a. When did you start work at your next most recent job?

Month: Year: 19

Q8b. When did you stop working at this next most recent job?

Month: Year: 19

OR I am currently still employed at this job.

Q8c. Which of the following best describes the type of work you did at this next most recent job? [CIRCLE ONE.]
1. Professional
7. Service (e.g., food service)
2. Technical
8. Craft/skilled worker
3. Managerial
9. Machine operator
4. Sales: High-Level
10. Professional driver
5. Sales: Clerical
11. Laborer
6. Non-Sales: Clerical
12. Other (please specify:

Q8d. In an average week, how many hours do/did you work at this next most recent job? hours/week (average)

Q8e. In an average week, what are/were your gross earnings at this next most recent job? /week average gross earnings (before taxes or withholdings) 
Q8f. If you are not still working at this job, why did you leave? [CIRCLE ONE.]
1. Better opportunity
5. Resignation/unsatisfactory job conditions
2. Layoff/termination
6. Return to school
3. Medical/disability
7. End of temporary job
4. Relocation
8. Retirement

Q9. Were you employed at the time of your alcohol-related accident?
1. Yes
2. No [If No, SKIP to Q11.]

Q10. What was the total income you lost as a direct result of your involvement in this accident in the following categories?

$\$$ in total uncompensated lost work time

$\$$ in the difference between my regular pay and any disability payments I received

$\$$ /week in reduced income due to job loss or inability to do my job

Q11. In which of the following ethnic groups would you classify yourself? [CIRCLE ONE.]

1. White, not of Hispanic Origin

2. African-American, not of Hispanic Origin

3. Hispanic

Q12. What is your date of birth (month and year)?

Q13. What is your gender? [CIRCLE ONE.]

4. Native American

5. Asian/Pacific Islander
1. Male
2. Female

Q14. What was your highest level of education at the time of your alcohol-related accident? [CIRCLE ONE.]

1. Junior high school (or less)

5. Some college, but no degree

2. Some high school

6. Associates or 2-year college degree

3. High school graduate

7. Bachelors or 4-year college degree

4. Trade school certificate

8. Masters or doctorate degree

Q15. What was your marital status at time of your alcohol-related accident? [CIRCLE ONE.]
1. Single
4. Separated
2. Married
5. Widowed

3. Divorced 


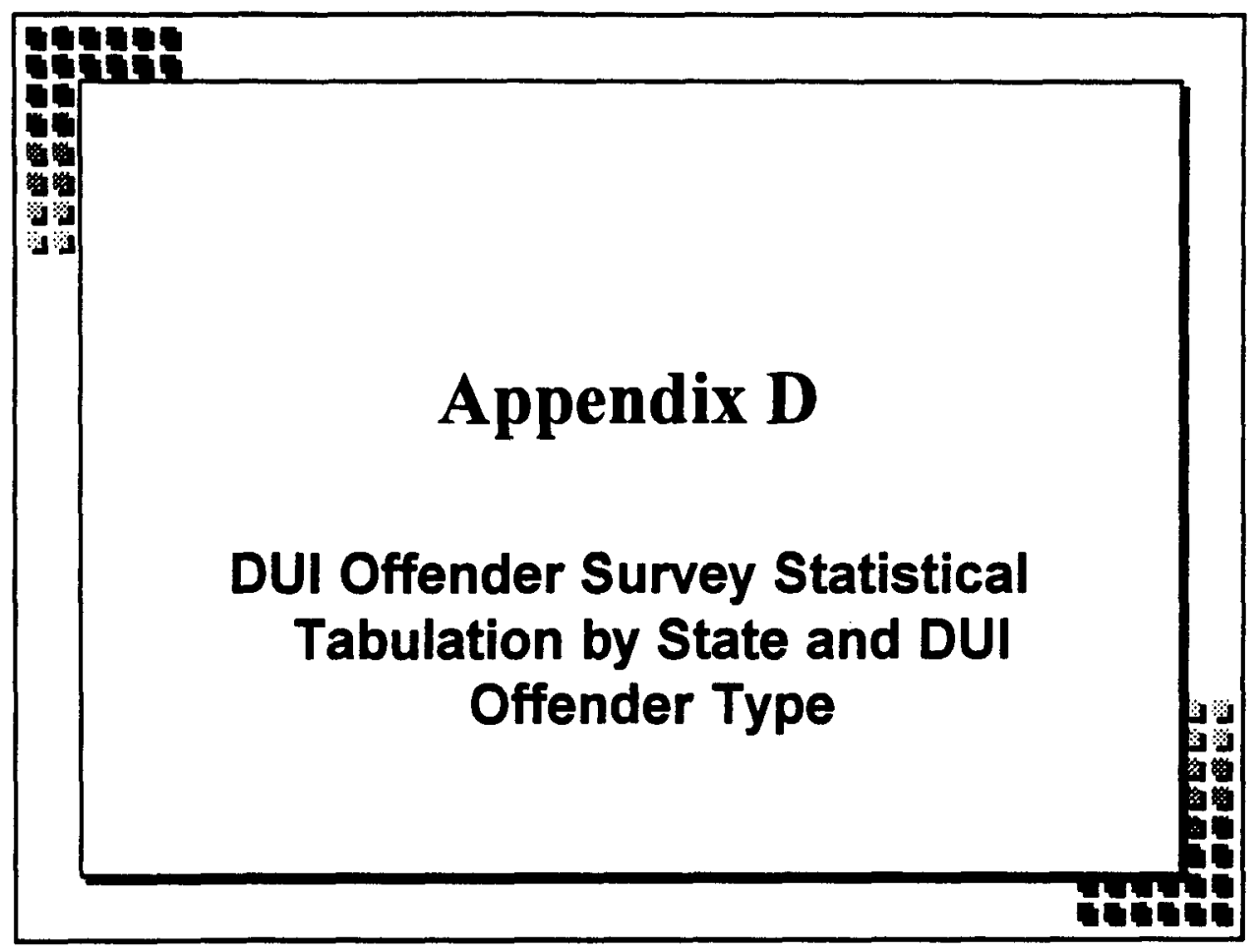


Effects of Administrative License Revocation on Employment

Freguency Tables by State of fender Type and Total
Q4) DID YOU HAVE A LICENSE AT THE IME OF THIS MOST RECENT DUI ARREST?

\begin{tabular}{|c|c|c|c|c|c|c|c|c|c|c|c|c|}
\hline & & \multicolumn{8}{|c|}{ STATE } & \multirow{2}{*}{\multicolumn{2}{|c|}{ Total }} & \multirow[b]{4}{*}{ Total } \\
\hline & & \multicolumn{2}{|c|}{ Pennsylvania } & \multicolumn{2}{|c|}{ Maryland } & \multicolumn{2}{|c|}{ California } & \multicolumn{2}{|c|}{ Delaware } & & & \\
\hline & & \multicolumn{2}{|c|}{ OFFENDER TYPE } & \multicolumn{2}{|c|}{ OFFENDER TYPE } & \multicolumn{2}{|c|}{ OF FENDER TYPE } & \multicolumn{2}{|c|}{ OFFENDER TYPE } & \multicolumn{2}{|c|}{ OFFENDER TYPE } & \\
\hline & & First & Multiple & First & Multiple & First & Multiple & First & Multiple & First & Mult iple & \\
\hline \multicolumn{13}{|c|}{ RESPONSE } \\
\hline \multirow[t]{2}{*}{ Yes } & & 162 & 56 & 93 & 33 & 168 & 61 & 140 & 31 & 563 & 181 & 744 \\
\hline & Columm Percent & 98.2 & 86.2 & 96.9 & 89.2 & 98.8 & 75.3 & 97.9 & 67.4 & 98.1 & 79.0 & 92.7 \\
\hline \multirow[t]{2}{*}{ No } & & 3 & 9 & 3 & 4 & 2 & 20 & 3 & 15 & 11 & 48 & 59 \\
\hline & Col umn Percent & 1.8 & 13.8 & 3.1 & 10.8 & 1.2 & 24.7 & 2.1 & 32.6 & 1.9 & 21.0 & 7.3 \\
\hline \multicolumn{2}{|c|}{ Total } & 165 & 65 & 96 & 37 & 170 & 81 & 143 & 46 & 574 & 229 & 803 \\
\hline
\end{tabular}


Effects of Administrative License Revocation on Employment Freguency Tables by State, offender Type, and Total

\begin{tabular}{|c|c|c|c|c|c|c|c|c|c|c|c|c|}
\hline & & \multicolumn{8}{|c|}{ STATE } & \multirow{2}{*}{\multicolumn{2}{|c|}{ Total }} & \multirow[b]{4}{*}{ Total } \\
\hline & & \multicolumn{2}{|c|}{ Pennsylvania } & \multicolumn{2}{|c|}{ Maryl and } & \multicolumn{2}{|c|}{ California } & \multicolumn{2}{|c|}{ Delaware } & & & \\
\hline & & \multicolumn{2}{|c|}{ OFFENDER TYPE } & \multicolumn{2}{|c|}{ OFFENDER TYPE } & \multicolumn{2}{|c|}{ OFFENDER TYPE } & \multicolumn{2}{|c|}{ OFFENDER TYPE } & \multicolumn{2}{|c|}{ OFFENDER TYPE } & \\
\hline & & First & Mult iple & First & Multiple & First & Multiple & First & Multiple & First & Multiple & \\
\hline \multicolumn{13}{|l|}{ RESPONSE CATEGORY } \\
\hline \multirow[t]{2}{*}{ lave not lost license } & & 38 & 9 & 45 & 13 & 11 & 4 & 12 & -- & 106 & 26 & 132 \\
\hline & Column Percent & 22.8 & 15.3 & 48.4 & 39.4 & 6.5 & 6.2 & 8.5 & $\cdots$ & 18.6 & 13.4 & 17.3 \\
\hline \multirow[t]{2}{*}{ imonths or less } & & 64 & 9 & 11 & 4 & 93 & 12 & 54 & 1 & 222 & 26 & 248 \\
\hline & Column Percent & 38.3 & 15.3 & 11.8 & 12.1 & 54.7 & 18.5 & 38.3 & 2.7 & 38.9 & 13.4 & 32.4 \\
\hline \multirow[t]{2}{*}{ 3etween 4 and 6 months } & & 18 & 10 & 17 & 3 & 41 & 18 & 35 & 5 & 111 & 36 & 147 \\
\hline & Column Percent & 10.8 & 16.9 & 18.3 & 9.1 & 24.1 & 27.7 & 24.8 & 13.5 & 19.4 & 18.6 & 19.2 \\
\hline \multirow[t]{2}{*}{ More than 6 months } & & 47 & 31 & 20 & 13 & 25 & 31 & 40 & 31 & 132 & 106 & 238 \\
\hline & Column Percent & 28.1 & 52.5 & 21.5 & 39.4 & 14.7 & 47.7 & 28.4 & 83.8 & 23.1 & 54.6 & 31.1 \\
\hline \multicolumn{2}{|l|}{ otal } & 167 & 59 & 93 & 33 & 170 & 65 & 141 & 37 & 571 & 194 & 765 \\
\hline
\end{tabular}


Effects of Administrative License Revocation on Employment

Freguency Tables by State of fender Type and Total
06) WAS THIS MOSI RECENT DUI ARREST YOUR FIRST DUI ARRES SINCE YOU STARTED DRIVING?

\begin{tabular}{|c|c|c|c|c|c|c|c|c|c|c|c|c|}
\hline & & \multicolumn{8}{|c|}{ STATE } & \multirow{2}{*}{\multicolumn{2}{|c|}{ Total }} & \multirow[b]{4}{*}{ Total } \\
\hline & & \multirow{2}{*}{\multicolumn{2}{|c|}{$\begin{array}{l}\text { Pennsylvania } \\
\text { OFFENDER TYPE }\end{array}$}} & \multicolumn{2}{|c|}{ Maryland } & \multicolumn{2}{|c|}{ Cal ifornia } & \multicolumn{2}{|c|}{ Delaware } & & & \\
\hline & & & & OFFENDER & TYPE & OF FENDER & TYPE & OFFENDE & TYPE & OFFENDE & TYPE & \\
\hline & & First & Mult iple & First & Multiple & First & Multiple & First & Multiple & First & Mult iple & \\
\hline \multicolumn{13}{|c|}{ RESPONSE } \\
\hline \multirow[t]{2}{*}{ Yes } & & 168 & -- & 96 & -- & 171 & --1 & 144 & -- & 579 & -- & 579 \\
\hline & Column Percent & 100.0 & -- & 100.0 & -- & 100.0 & -- & 100.0 & $\cdots$ & 100.0 & $\cdots$ & 71.9 \\
\hline \multirow[t]{2}{*}{ No } & & -- & 63 & -- & 38 & -1 & 79 & -- & 46 & -- & 226 & 226 \\
\hline & Colum Percent & -- & 100.0 & -- & 100.0 & -- & 100.0 & -- & 100.0 & $\cdots$ & 100.0 & 28.1 \\
\hline Total & & 168 & 63 & 96 & 38 & 171 & 79 & 144 & 46 & 579 & 226 & 805 \\
\hline
\end{tabular}


Frequency Tables by State, Offender Iype and Total ho
Q7) HOW MANY TOTAL DUI ARRESTS (INCLUDING THIS'MOST RECENT GNE) HAVE YOU HAD IN THE LAST YEAR?

\begin{tabular}{|c|c|c|c|c|c|c|c|}
\hline & & & STA & ATE & & & \\
\hline & & $\begin{array}{c}\text { Pennsylva- } \\
\text { nia }\end{array}$ & Maryl and & Cal ifornia & Delaware & Total & \\
\hline & & $\begin{array}{c}\text { OFFENDER } \\
\text { TYPE }\end{array}$ & $\begin{array}{c}\text { OFFENDER } \\
\text { TYPE }\end{array}$ & $\begin{array}{c}\text { OFFENDER } \\
\text { TYPE }\end{array}$ & $\begin{array}{l}\text { OFFENDER } \\
\text { TYPE }\end{array}$ & $\begin{array}{l}\text { OFFENDER } \\
\text { TYPE }\end{array}$ & \\
\hline & & Multiple & Multiple & Multiple & Multiple & Multiple & Total \\
\hline & & & & & & & \\
\hline 1 & & 52 & 28 & 67 & 40 & 187 & 187 \\
\hline & Column Percent & 82.5 & 73.7 & 83.8 & 87.0 & 82.4 & 82.4 \\
\hline 2 & & 11 & 8 & 12 & 6 & 37 & 37 \\
\hline & Column Percent & 17.5 & 21.1 & 15.0 & 13.0 & 16.3 & 16.3 \\
\hline 3 & & -- & 2 & 1 & -- & 3 & 3 \\
\hline & Column Percent & -- & 5.3 & 1.3 & $\cdots$ & 1.3 & 1.3 \\
\hline & & 63 & 38 & 80 & 46 & 227 & 227 \\
\hline
\end{tabular}


Q8) HOW MANY TOTAL DUI ARRESTS (INCLUDING THIS MOST RECENT ONE), HAVE YOU HAD IN THE LAST 5 YEARS?

\begin{tabular}{|c|c|c|c|c|c|c|c|}
\hline & & \multicolumn{4}{|c|}{ STATE } & \multirow[b]{2}{*}{ Total } & \multirow[b]{4}{*}{ Total } \\
\hline & & $\underset{\text { Pennsylva- }}{\text { nia }}$ & Maryl and & Cal ifornia & Delaware & & \\
\hline & & $\begin{array}{c}\text { OFFENDER } \\
\text { TYPE }\end{array}$ & $\begin{array}{c}\text { OF FENDER } \\
\text { TYPE }\end{array}$ & $\begin{array}{c}\text { OF FENDER } \\
\text { TYPE }\end{array}$ & $\begin{array}{c}\text { OFFENDER } \\
\text { TYPE }\end{array}$ & $\begin{array}{c}\text { OFFENDER } \\
\text { TYPE }\end{array}$ & \\
\hline & & Multiple & Multiple & Mut tiple & Mult iple & Multiple & \\
\hline \multicolumn{2}{|c|}{ RESPONSE } & \multirow[b]{2}{*}{12} & \multirow[b]{2}{*}{--} & \multirow[b]{2}{*}{18} & \multirow[b]{2}{*}{15} & \multirow[b]{2}{*}{45} & \multirow[b]{2}{*}{45} \\
\hline \multirow[t]{2}{*}{1} & & & & & & & \\
\hline & Column Percent & 19.4 & $\cdots$ & 22.5 & 32.6 & 19.9 & 19.9 \\
\hline \multirow[t]{2}{*}{2} & & 43 & 27 & 60 & 26 & 156 & 156 \\
\hline & Column Percent & 69.4 & 71.1 & 75.0 & 56.5 & 69.0 & 69.0 \\
\hline \multirow[t]{2}{*}{3} & & 7 & 7 & 2 & 5 & 21 & 21 \\
\hline & Column Percent & 11.3 & 18.4 & 2.5 & 10.9 & 9.3 & 9.3 \\
\hline \multirow[t]{2}{*}{4} & & -- & 3 & -- & $\cdots$ & 3 & 3 \\
\hline & Column Percent & $\cdots$ & 7.9 & -- & -- & 1.3 & 1.3 \\
\hline \multirow[t]{2}{*}{5} & & -- & 1 & -- & -- & 1 & 1 \\
\hline & Column Percent & -- & 2.6 & $\cdots$ & -- & 0.4 & 0.4 \\
\hline \multicolumn{2}{|c|}{ Total } & 62 & 38 & 80 & 46 & 226 & 226 \\
\hline
\end{tabular}


Q11D) WHICH OF THE FOLLOWING BEST DESCRIBES THE TYPPE OF WORK YOU DO AT YOUR CURRENT JOB (OR MOST RECENT JOB IF YOU ARE CURRENTLY NOT EMPLOYED)?

\section{RESPONSE}

01) Professional

02) Technical

03) Managerial

04) Sales: High-Level

05) Sales: Clerical

06) Non-Sales: Clerical

07) Service (e.g., food service) Column Percent Column Percent

08) Craft/skilled worker

09) Machine operator

10) Professional driver

11) Laborer

13) No employment 1992-1994

Column Percent

Col umn Percent

Column Percent

Column Percent

Column Percent

Column Percent

STATE

\begin{tabular}{|c|c|c|c|c|c|c|c|c|c|c|}
\hline \multicolumn{8}{|c|}{ STATE } & \multirow{2}{*}{\multicolumn{2}{|c|}{ Total }} & \multirow[b]{4}{*}{ Total } \\
\hline \multicolumn{2}{|c|}{ Pennsylvania } & \multicolumn{2}{|c|}{ Maryl and } & \multicolumn{2}{|c|}{ Cal ifornia } & \multicolumn{2}{|c|}{ Delaware } & & & \\
\hline \multicolumn{2}{|c|}{ OFFENDER TYPE } & \multicolumn{2}{|c|}{ OFFENDER TYPE } & \multicolumn{2}{|c|}{ OFFENDER TYPE } & \multicolumn{2}{|c|}{ OFFENDER IYPE } & \multicolumn{2}{|c|}{ OFFENDER TYPE } & \\
\hline First & Multiple & First & Multiple & first & Mul tiple & First & Multiple & First & Multiple & \\
\hline 25 & 4 & 14 & 6 & 40 & 13. & 20 & 3 & 99 & 26 & 125 \\
\hline 15.5 & 6.6 & 14.7 & 17.1 & 24.0 & 16.5 & 14.4 & 6.5 & 17.6 & 11.8 & 16.0 \\
\hline 14 & 3 & 8 & -- & 15 & 8 & 12 & 4 & 49 & 15 & 64 \\
\hline 8.7 & 4.9 & 8.4 & $\cdots$ & 9.0 & 10.1 & 8.6 & 8.7 & 8.7 & 6.8 & 8.2 \\
\hline 14 & 6 & 13 & 5 & 21 & 10 & 18 & 1 & 66 & 22 & 88 \\
\hline 8.7 & 9.8 & 13.7 & 14.3 & 12.6 & 12.7 & 12.9 & 2.2 & 11.7 & 10.0 & 11.2 \\
\hline 13 & 4 & 6 & 1 & 21 & 9 & 12 & 1 & 52 & 15 & 67 \\
\hline 8.1 & 6.6 & 6.3 & 2.9 & 12.6 & 11.4 & 8.6 & 2.2 & 9.3 & 6.8 & 8.6 \\
\hline 6 & 2 & 1 & 1 & 5 & $\cdots$ & 4 & -- & 16 & 3 & 19 \\
\hline 3.7 & 3.3 & 1.1 & 2.9 & 3.0 & -- & 2.9 & -- & 2.8 & 1.4 & 2.4 \\
\hline 3 & $\cdots$ & $\cdots$ & $\cdots$ & 1 & 1 & 1 & 1 & 5 & 2 & 7 \\
\hline 1.9 & $\cdots$ & $-\because$ & $\cdots$ & 0.6 & 1.3 & 0.7 & 2.2 & 0.9 & 0.9 & 0.9 \\
\hline 23 & 7 & 10 & 3 & 24 & 7 & 14 & 6 & 71 & 23 & 94 \\
\hline 14.3 & 11.5 & 10.5 & 8.6 & 14.4 & 8.9 & 10.1 & 13.0 & 12.6 & 10.4 & 12.0 \\
\hline 25 & 24 & 23 & 8 & 13 & 14 & 31 & 18 & 92 & 64 & 156 \\
\hline 15.5 & 39.3 & 24.2 & 22.9 & 7.8 & 17.7 & 22.3 & 39.1 & 16.4 & 29.0 & 19.9 \\
\hline 7 & 4 & 3 & 2 & 3 & 1 & 4 & 7 & 17 & 14 & 31 \\
\hline 4.3 & 6.6 & 3.2 & 5.7 & 1.8 & 1.3 & 2.9 & 15.2 & 3.0 & 6.3 & 4.0 \\
\hline 5 & -- & 6 & 1 & 6 & 2 & 4 & -- & 21 & 3 & 24 \\
\hline 3.1 & $\cdots$ & 6.3 & 2.9 & 3.6 & 2.5 & 2.9 & -- & 3.7 & 1.4 & 3.1 \\
\hline 18 & 5 & 7 & 7 & 10 & 3 & 13 & 4 & 48 & 19 & 67 \\
\hline 11.2 & 8.2 & 7.4 & 20.0 & 6.0 & 3.8 & 9.4 & 8.7 & 8.5 & 8.6 & 8.6 \\
\hline 8 & 2 & 4 & 1 & 8 & 11 & 6 & 1 & 26 & 15 & 41 \\
\hline 5.0 & 3.3 & 4.2 & 2.9 & 4.8 & 13.9 & 4.3 & $\begin{array}{l}0.2 \\
\end{array}$ & 4.6 & 6.8 & 5.2 \\
\hline 161 & 61 & 95 & 35 & 167 & 79 & 139 & 46 & 562 & 221 & 783 \\
\hline
\end{tabular}

Total

161

61

139

783 
Q110) WHICH OF THE FOLLOWING BEST DESCRIBES THE TYPE OF WORK YOU DO AT YOUR CURRENT JOB (OR MOST RECENT JOB IF YOU ARE CURRENTLY NOT EMPLOYED)?

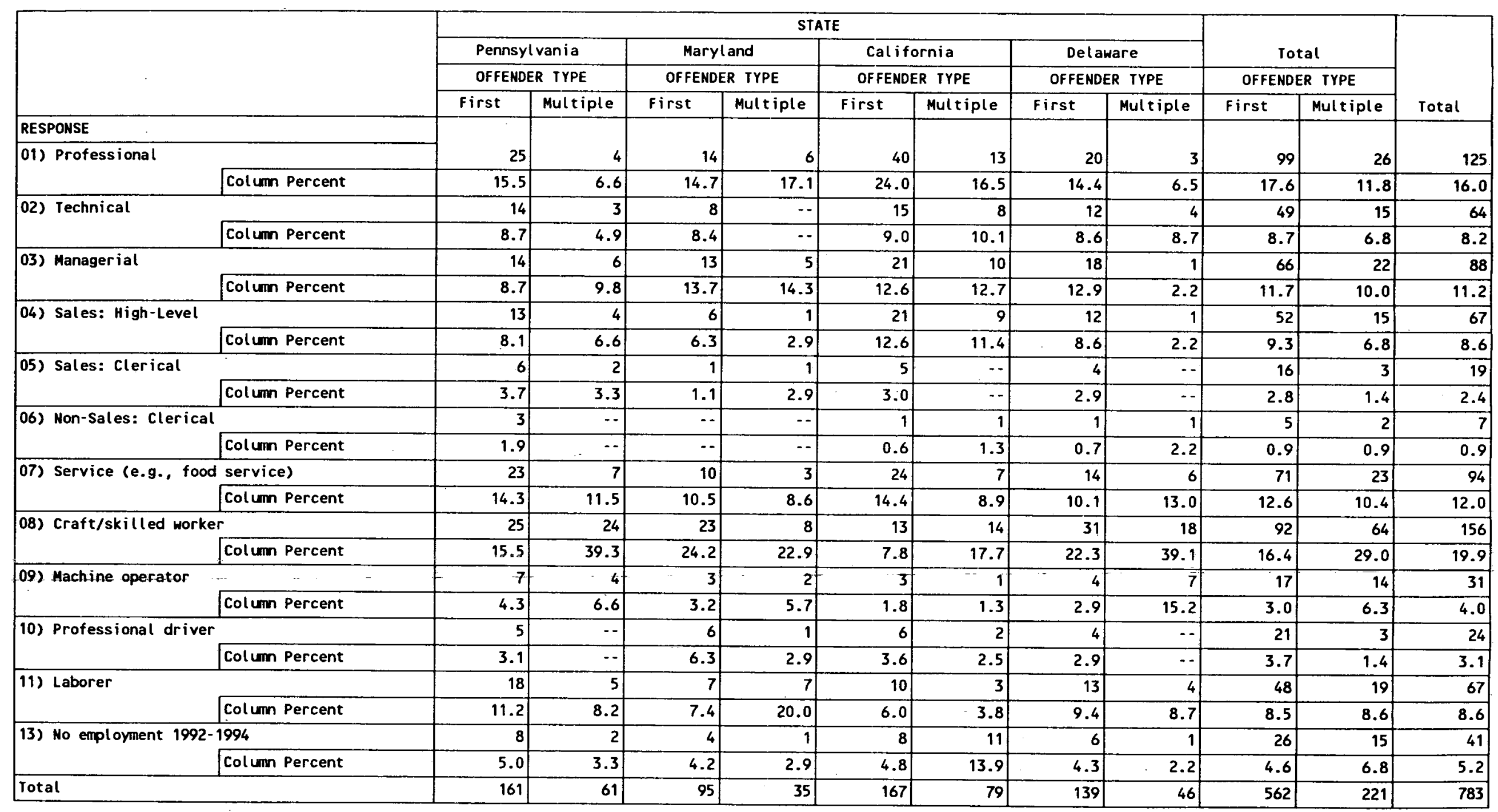


Effects of Administrative License Revocation on Employment

Q11F) HOW WOULD YOU DESCRIBE YOUR NEED TO DRIVE AT YOUR CURRENT JOB (OR MOST RECENT JOB)?

\begin{tabular}{|c|c|c|c|c|c|c|c|c|c|c|c|}
\hline & \multicolumn{8}{|c|}{ STATE } & \multirow{2}{*}{\multicolumn{2}{|c|}{ Total }} & \multirow[b]{4}{*}{ Total } \\
\hline & \multicolumn{2}{|c|}{ Pennsylvania } & \multicolumn{2}{|c|}{ Maryland } & \multicolumn{2}{|c|}{ Cal ifornia } & \multicolumn{2}{|c|}{ Delaware } & & & \\
\hline & \multicolumn{2}{|c|}{ OFFENDER TYPE } & \multicolumn{2}{|c|}{ OFFENDER TYPE } & \multicolumn{2}{|c|}{ OFFENDER TYPE } & \multicolumn{2}{|c|}{ OFFENDER TYPE } & \multicolumn{2}{|c|}{ OFFENDER TYPE } & \\
\hline & First & Multiple & First & Multiple & First & Multiple & First & Multiple & First & Multiple & \\
\hline RESPONSE & \multirow[b]{2}{*}{38} & \multirow[b]{2}{*}{22} & \multirow[b]{2}{*}{18} & \multirow[b]{2}{*}{11} & \multirow[b]{2}{*}{26} & \multirow[b]{2}{*}{18} & \multirow[b]{2}{*}{29} & \multirow[b]{2}{*}{22} & \multirow[b]{2}{*}{111} & \multirow[b]{2}{*}{73} & \multirow[b]{2}{*}{184} \\
\hline 1) I don't require a vehicte to do my job. & & & & & & & & & & & \\
\hline Column Percent & 18.1 & 25.0 & 15.0 & 22.0 & 13.3 & 21.2 & 15.7 & 32.8 & 15.6 & 25.2 & 18.4 \\
\hline \multirow{2}{*}{$\begin{array}{l}\text { 2) I use my own vehicle to commute to work only. } \\
\text { Column Percent }\end{array}$} & 66 & 21 & 34 & 11 & 49 & 20 & 55 & 17 & 204 & 69 & 273 \\
\hline & 31.4 & 23.9 & 28.3 & 22.0 & 25.0 & 23.5 & 29.7 & 25.4 & 28.7 & 23.8 & 27.3 \\
\hline $\begin{array}{l}\text { 3) I drive my own vehicle as part of my job } \\
\text { somet imes. }\end{array}$ & 26 & 12 & 18 & 5 & 34 & 14 & 24 & 8 & 102 & 39 & 141 \\
\hline Colum Percent & 12.4 & 13.6 & 15.0 & 10.0 & 17.3 & 16.5 & 13.0 & 11.9 & 14.3 & 13.4 & 14.1 \\
\hline $\begin{array}{l}\text { 4) I drive my own vehicle as part of my job } \\
\text { every day. }\end{array}$ & 38 & 15 & 22 & 12 & 50 & 19 & 28 & 11 & 138 & 57 & 195 \\
\hline Column Percent & 18.1 & 17.0 & 18.3 & 24.0 & 25.5 & 22.4 & 15.1 & 16.4 & 19.4 & 19.7 & 19.5 \\
\hline $\begin{array}{l}\text { 5) I drive another vehicle as part of my job } \\
\text { somet imes. }\end{array}$ & 22 & 9 & 8 & 6 & 18 & 6 & 20 & 3 & 68 & 24 & 92 \\
\hline Columin Percent & 10.5 & 10.2 & 6.7 & 12.0 & 9.2 & 7.1 & 10.8 & 4.5 & 9.6 & 8.3 & 9.2 \\
\hline $\begin{array}{l}\text { 6) I drive another vehicle as part of my job } \\
\text { every day. }\end{array}$ & 20 & 9 & 20 . & 5 & 19 & 8 & 29 & 6 & 88 & 28 & 116 \\
\hline Col umn Percent & 9.5 & 10.2 & 16.7 & 10.0 & 9.7 & 9.4 & 15.7 & 9.0 & 12.4 & 9.7 & 11.6 \\
\hline Total & 210 & 88 & 120 & 50 & 196 & 85 & 185 & 67 & 711 & 290 & 1001 \\
\hline
\end{tabular}


Effects of Administrative License Revocation on Employment

Frequency Tables by State Of Offender Type, and Total
0111) IF YOU ARE NOT STILC WORKING AT THIS JOB, WHY DID YOU LEAVE?

\begin{tabular}{|c|c|c|c|c|c|c|c|c|c|c|c|c|}
\hline & & \multicolumn{8}{|c|}{ STATE } & \multirow{2}{*}{\multicolumn{2}{|c|}{ Total }} & \multirow[b]{4}{*}{ Total } \\
\hline & & \multicolumn{2}{|c|}{ Pennsylvania } & \multicolumn{2}{|c|}{ Maryl and } & \multicolumn{2}{|c|}{ California } & \multicolumn{2}{|c|}{ Delaware } & & & \\
\hline & & \multicolumn{2}{|c|}{ OFFENDER TYPE } & \multicolumn{2}{|c|}{ OFFENDER TYPE } & \multicolumn{2}{|c|}{ OFFENDER TYPE } & \multicolumn{2}{|c|}{ OFFENDER TYPE } & \multicolumn{2}{|c|}{ OFFENDER TYPE } & \\
\hline - & & First & Multiple & First & Mult iple & First & Multiple & First & Multiple & First & Multiple & \\
\hline \multicolumn{2}{|l|}{ RESPONSE } & & & & & & & & & & & \\
\hline \multirow[t]{2}{*}{ 01) Better opportunity } & & -- & 1 & 1 & -- & 1 & $\cdots$ & $\cdots$ & $\cdots$ & 2 & 1 & 3 \\
\hline & Column Percent & $\cdots$ & 12.5 & 10.0 & -- & 6.3 & -- & $\cdots$ & $\cdots$ & 4.5 & 3.8 & 4.3 \\
\hline \multirow[t]{2}{*}{ 02) Layoff/termination } & & 3 & 1 & 4 & $\cdots$ & 2 & 3 & 2 & 1 & 11 & 5 & 16 \\
\hline & Column Percent & 30.0 & 12.5 & 40.0 & -- & 12.5 & 23.1 & 25.0 & 50.0 & 25.0 & 19.2 & 22.9 \\
\hline \multirow[t]{2}{*}{ 03) Medical/disability } & & 1 & $\cdots$ & 1 & -- & 2 & 2 & 1 & $\cdots$ & 5 & 2 & 7 \\
\hline & Column Percent & 10.0 & $\cdots$ & 10.0 & -- & 12.5 & 15.4 & 12.5 & $\cdots$ & 11.4 & 7.7 & 10.0 \\
\hline \multirow[t]{2}{*}{ 04) DUI/loss of license } & & 2 & 5 & 2 & 3 & 6 & 7 & 4 & 1 & 14 & 16 & 30 \\
\hline & Column Percent & 20.0 & 62.5 & 20.0 & 100.0 & 37.5 & 53.8 & 50.0 & 50.0 & 31.8 & 61.5 & 42.9 \\
\hline \multirow[t]{2}{*}{ 05) Relocation } & & 1 & $\cdots$ & -- & -- & $\cdots$ & $\cdots$ & $\cdots$ & $\cdots$ & 1 & -- & 1 \\
\hline & Column Percent & 10.0 & $\cdots$ & -- & $\cdots$ & $\cdots$ & -- & -- & $\cdots$ & 2.3 & -- & 1.4 \\
\hline \multicolumn{2}{|c|}{ 06) Resignation/unsat isfactory job conditions } & -- & -- & $\cdots$ & $\cdots$ & -- & -- & 1 & $\cdots$ & 1 & -- & 1 \\
\hline & Column Percent & $\cdots$ & -- & $\cdots$ & $\cdots$ & $\cdots$ & $\cdots$ & 12.5 & -- & 2.3 & +- & 1.4 \\
\hline \multirow[t]{2}{*}{ 07) Return to school } & & 1 & $\cdots$ & 1 & $\cdots$ & 1 & 1 & -- & $\cdots$ & 3 & 1 & 4 \\
\hline & Column Percent & 10.0 & $\cdots$ & 10.0 & -- & 6.3 & 7.7 & $\cdots$ & $\cdots$ & 6.8 & 3.8 & 5.7 \\
\hline \multicolumn{2}{|l|}{ 08) End of temporary job } & $\cdots$ & $\cdots$ & $-\cdot$ & $\cdots$ & 3 & $\cdots$ & $\cdots$ & -- & 3 & -- & 3 \\
\hline & Column Percent & -- & -- & $\cdots$ & $\cdots$ & 18.8 & $-\cdot$ & $\cdots$ & $\cdots$ & 6.8 & $\cdots$ & 4.3 \\
\hline \multirow[t]{2}{*}{ 09) Retired } & & 2 & 1 & 1 & $\cdots$ & 1 & $\cdots$ &.- & -- & 4 & 1 & 5 \\
\hline & Column Percent & 20.0 & 12.5 & 10.0 & $\cdots$ & 6.3 & $\cdots$ & -- & $\cdots$ & 9.1 & 3.8 & 7.1 \\
\hline \multicolumn{2}{|l|}{ Total } & 10 & 8 & 10 & 3 & 16 & 13 & 8 & 2 & 44 & 26 & 70 \\
\hline
\end{tabular}


Effects of Adninistrative License Revocation on Employment

Freguency Tables by State Offender Type, and Total
Q12C) WHICH OF THE FOLLOWING BEST DESCRIBES THE INDUSTRY OR TYPE GF EMPLOYER OF YOUR NEXT MOST RECENT JOB?

\begin{tabular}{|c|c|c|c|c|c|c|c|c|c|c|c|c|c|}
\hline & & & \multicolumn{8}{|c|}{ STATE } & \multirow{2}{*}{\multicolumn{2}{|c|}{ Total }} & \multirow[b]{4}{*}{ Total } \\
\hline & & & \multicolumn{2}{|c|}{ Pennsylvania } & \multicolumn{2}{|c|}{ Maryland } & \multicolumn{2}{|c|}{ Cal ifornia } & \multicolumn{2}{|c|}{ Delaware } & & & \\
\hline & & & \multicolumn{2}{|c|}{ OFFENDER IYPE } & \multicolumn{2}{|c|}{ OFFENDER TYPE } & \multicolumn{2}{|c|}{ OFFENDER TYPE } & \multicolumn{2}{|c|}{ OFFENDER TYPE } & \multicolumn{2}{|c|}{ OFFENDER TYPE } & \\
\hline & & & First & Multiple & First & Multiple & First & Mul tiple & First & Multiple & First & Multiple & \\
\hline \multicolumn{14}{|c|}{ RESPONSE } \\
\hline \multirow[t]{2}{*}{ 01) } & Agriculture & & -- & -- & 1 & -- & 1 & -- & $\cdots$ & 1 & 2 & 1 & 3 \\
\hline & & Colum Percent & $\cdots$ & $\cdots$ & 3.2 & -- & 2.0 & -- & -- & 6.7 & 1.1 & 1.4 & 1.2 \\
\hline \multirow[t]{2}{*}{ 03) } & Construction & & 6 & 6 & 3 & 3 & 2 & 4 & 9 & 5 & 20 & 18 & 38 \\
\hline & & Column Percent & 10.5 & 23.1 & 9.7 & 20.0 & 4.0 & 28.6 & 20.9 & 33.3 & 11.0 & 25.7 & 15.1 \\
\hline \multirow[t]{2}{*}{ 04) 1} & Manufacturing & & 2 & 4 & 1 & $\cdots$ & 3 & -- & 3 & 1 & 9 & 5 & 14 \\
\hline & & Colum Percent & 3.5 & 15.4 & 3.2 & -- & 6.0 & $\cdots$ & 7.0 & 6.7 & 5.0 & 7.1 & 5.6 \\
\hline \multirow[t]{2}{*}{ 05) } & Transportation & & -- & 2 & 3 & $\cdots$ & 2 & -- & -- & -- & 5 & 2 & 7 \\
\hline & & Column Percent & -- & 7.7 & 9.7 & -- & 4.0 & $\cdots$ & -- & $\cdots$ & 2.8 & 2.9 & 2.8 \\
\hline \multirow[t]{2}{*}{ 06) } & Utilities & & $\cdots$ & $\cdots$ & 1 & 1 & 2 & 1 & -- & 1 & 3 & 3 & 6 \\
\hline & & Colum Percent & -- & -- & 3.2 & 6.7 & 4.0 & 7.1 & -- & 6.7 & 1.7 & 4.3 & 2.4 \\
\hline \multirow[t]{2}{*}{ 07) } & Wholesale trade & & -- & -- & 2 & 1 & 2 & -- & 1 & -- & 5 & 1 & 6 \\
\hline & & Column Percent & -- & -- & 6.5 & 6.7 & 4.0 & -- & 2.3 & $\cdots$ & 2.8 & 1.4 & 2.4 \\
\hline \multirow[t]{2}{*}{ 08) } & Retail trade & & 7 & 6 & 5 & 4 & 4 & 2 & 6 & 1 & 22 & 13 & 35 \\
\hline & & Column Percent & 12.3 & 23.1 & 16.1 & 26.7 & 8.0 & 14.3 & 14.0 & 6.7 & 12.2 & 18.6 & 13.9 \\
\hline \multirow[t]{2}{*}{ 09) } & Finance/insurance/re & eal estate & 3 & $\cdots$ & 1 & -- & 8 & 3 & 3 & -- & 15 & 3 & 18 \\
\hline & & Column Percent & 5.3 & -- & 3.2 & -- & 16.0 & 21.4 & 7.0 & -- & 8.3 & 4.3 & 7.2 \\
\hline \multirow[t]{2}{*}{ 10) } & Services & & 38 & 7 & 12 & 6 & 25 & 4 & 19 & 6 & 94 & 23 & 117 \\
\hline & & Colum Percent & 66.7 & 26.9 & 38.7 & 40.0 & 50.0 & 28.6 & 44.2 & 40.0 & 51.9 & 32.9 & 46.6 \\
\hline \multirow[t]{2}{*}{ 11) } & Local/state governme & & 1 & $\cdots$ & -- & $\cdots$ & -- & -- & 1 & $\cdots$ & 2 & $\cdots$ & 2 \\
\hline & & Colum Percent & 1.8 & -- & $\cdots$ & -- & -- & -- & 2.3 & -- & 1.1 & $\cdots$ & 0.8 \\
\hline \multirow[t]{2}{*}{ 12) } & Federal government & & -- & $\cdots$ & 1 & -- & $\cdots$ & -- & -- & -- & 1 & $\cdots$ & 1 \\
\hline & & Column Percent & $\cdots$ & -- & 3.2 & $\cdots$ & -- & -- & -- & $\cdots$ & 0.6 & -- & 0.4 \\
\hline \multirow[t]{2}{*}{ 13) } & Military & & -- & $\cdots$ & 1 & -- & 1 & $\cdots$ & 1 & -- & 3 & -- & 3 \\
\hline & & Column Percent & -- & $\cdots$ & 3.2 & $\cdots$ & 2.0 & -- & 2.3 & $\cdots$ & 1.7 & -- & 1.2 \\
\hline \multirow[t]{2}{*}{ 14) } & Other & & $\cdots$ & 1 & -- & -- & -- & -- & -- & -- & $\cdots$ & 1 & 1 \\
\hline & & Colum Percent & -- & 3.8 & $\cdots$ & $\cdots$ & $\cdots$ & -- & -- & $\cdots$ & $\cdots$ & 1.4 & 0.4 \\
\hline Tota & & & 57 & 26 & 31 & 15 & 50 & 14 & 43 & 15 & 181 & 70 & 251 \\
\hline
\end{tabular}

NOTE: This question includes job information for all jobs other than the current job (where more than one job was worked in 1992-1994). 
0120) WHICH OF THE FOLLOWING BEST DESCRIBES THE TYPE Of WORK YY You DID AT YOUR NEXT MOST RECENT JOB?

\begin{tabular}{|c|c|c|c|c|c|c|c|c|c|c|c|c|}
\hline & & \multicolumn{8}{|c|}{ STATE } & \multirow{2}{*}{\multicolumn{2}{|c|}{ Total }} & \multirow[b]{4}{*}{ Total } \\
\hline & & \multicolumn{2}{|c|}{ Pennsylvania } & \multicolumn{2}{|c|}{ Maryland } & \multicolumn{2}{|c|}{ California } & \multicolumn{2}{|c|}{ Delaware } & & & \\
\hline & & OFFEMDE & R TYPE & OFFENDE & TYPE & OFFENDEI & R TYPE & OFFENDE & $R$ TYPE & OFFENDE & R TYPE & \\
\hline & & First & Multiple & First & Multiple & First & Multiple & First & Multiple & First & Multiple & \\
\hline \multicolumn{2}{|c|}{ RESPONSE } & & & & & & & & & & & \\
\hline \multirow[t]{2}{*}{ 01) 7} & Professional & 9 & $\cdots$ & 3 & 2 & 13 & 2 & 7 & 2 & 32 & 6 & 38 \\
\hline & Column Percent & 16.1 & -- & 9.7 & 13.3 & 26.0 & 14.3 & 16.3 & 13.3 & 17.8 & 8.6 & 15.2 \\
\hline \multirow[t]{2}{*}{ 02) } & Technical & 2 & 3 & 3 & --1 & 6) & 1 & 1 & 3 & 12 & 7 & 19 \\
\hline & Colum Percent & 3.6 & 11.5 & 9.7 & -- & 12.0 & 7.1 & 2.3 & 20.0 & 6.7 & 10.0 & 7.6 \\
\hline \multirow[t]{2}{*}{ 03) } & Managerial & 4 & 1 & 4 & 2 & 6 & $\cdots$ & 11 & -- & 25 & 3 & 28 \\
\hline & Column Percent & 7.1 & 3.8 & 12.9 & 13.3 & 12.0 & -- & 25.6 & -- & 13.9 & 4.3 & 11.2 \\
\hline \multirow[t]{2}{*}{ 04) } & Sales: High-Level & 2 & 2 & 3 & -- & 5 & 3 & 1 & -- & 11 & 5 & 16 \\
\hline & Column Percent & 3.6 & 7.7 & 9.7 & $\cdots$ & 10.0 & 21.4 & 2.3 & -- & 6.1 & 7.1 & 6.4 \\
\hline \multirow[t]{2}{*}{ 05) } & Sales: Clerical & 4 & 2 & 1 & 1 & 1 & -1 & 3 & $\cdots$ & 9 & 3 & 12 \\
\hline & Column Percent & 7.1 & 7.7 & 3.2 & 6.7 & 2.0 & -- & 7.0 & $-\cdot$ & 5.0 & 4.3 & 4.8 \\
\hline \multirow[t]{2}{*}{ 06) } & Non-Sales: Clerical & 2 & -- & -- & 1 & 2 & -- & 2 & $\cdots$ & 6 & 1 & 7 \\
\hline & Column Percent & 3.6 & -- & -- & 6.7 & 4.0 & -- & 4.7 & $-\cdot$ & 3.3 & 1.4 & 2.8 \\
\hline \multirow[t]{2}{*}{ 07) } & Service (e.9., food service) & 14 & 3 & 5 & 2 & 12 & 3 & 7 & 3 & 38 & 11 & 49 \\
\hline & Column Percent & 25.0 & 11.5 & 16.1 & 13.3 & 24.0 & 21.4 & 16.3 & 20.0 & 21.1 & 15.7 & 19.6 \\
\hline \multirow[t]{2}{*}{ 08) } & Craft/skilled worker & 9 & 6 & 5 & 4 & 2 & 4 & 7 & 4 & 23 & 18 & 41 \\
\hline & Col umn Percent & 16.1 & 23.1 & 16.1 & 26.7 & 4.0 & 28.6 & 16.3 & 26.7 & 12.8 & 25.7 & 16.4 \\
\hline \multirow[t]{2}{*}{ 09) } & Machine operator & 1 & 1 & - & -- & 1 & $-\cdots$ & - & 1 & 2 & 2 & 4 \\
\hline & Col umn Percent & 1.8 & 3.8 & $\cdots$ & -- & 2.0 & -- & $\cdots$ & 6.7 & 1.1 & 2.9 & 1.6 \\
\hline \multirow[t]{2}{*}{ 10) } & Professional driver & 1 & 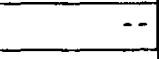 & 3 & 1 & $-\cdots$ & -- & $\therefore$ & -- & 4 & 1 & 5 \\
\hline & Column Percent & 1.8 & - & 9.7 & 6.7 & -- & -- & $\because$ & $\cdots$ & 2.2 & 1.4 & 2.0 \\
\hline \multirow[t]{2}{*}{ 11) } & Laborer & 8 & 8 & 4 & 2 & 2 & -1 & 4 & 2 & 18 & 13 & 31 \\
\hline & Col umn Percent & 14.3 & 30.8 & 12.9 & 13.3 & 4.0 & 7.1 & 9.3 & 13.3 & 10.0 & 18.6 & 12.4 \\
\hline Tota & & 56 & 26 & 31 & 15 & 50 & 14 & 431 & 15 & 180 & 70 & 250 \\
\hline
\end{tabular}


Effects of Administrative License Revocation on Employment

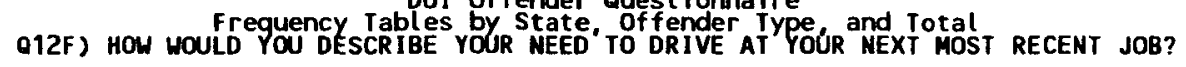

\begin{tabular}{|c|c|c|c|c|c|c|c|c|c|c|c|}
\hline & \multicolumn{8}{|c|}{ STATE } & \multirow{2}{*}{\multicolumn{2}{|c|}{ Total }} & \multirow[b]{4}{*}{ Total } \\
\hline & \multicolumn{2}{|c|}{ Pennsylvania } & \multicolumn{2}{|c|}{ Maryland } & \multicolumn{2}{|c|}{ California } & \multicolumn{2}{|c|}{ Delaware } & & & \\
\hline & \multicolumn{2}{|c|}{ OFFENDER TYPE } & \multicolumn{2}{|c|}{ OFFENDER TYPE } & \multicolumn{2}{|c|}{ OFFENDER TYPE } & \multicolumn{2}{|c|}{ OFFENDER TYPE } & \multicolumn{2}{|c|}{ OFFENDER TYPE } & \\
\hline & First & Multiple & First & Multiple & First & Multiple & First & Mul tiple & First & Multiple & \\
\hline RESPONSE & \multirow[b]{2}{*}{11} & \multirow[b]{2}{*}{8} & \multirow[b]{2}{*}{7} & \multirow[b]{2}{*}{5} & \multirow[b]{2}{*}{13} & \multirow[b]{2}{*}{1} & \multirow[b]{2}{*}{6} & \multirow[b]{2}{*}{5} & \multirow[b]{2}{*}{37} & \multirow[b]{2}{*}{19} & \multirow[b]{2}{*}{56} \\
\hline 1) I don't require a vehicle to do my job. & & & & & & & & & & & \\
\hline Column Percent & 17.2 & 22.9 & 21.9 & 25.0 & 22.0 & 5.3 & 10.3 & 27.8 & 17.4 & 20.7 & 18.4 \\
\hline 2) I use my own vehicle to commute to work only. & 27 & 12 & 14 & 7 & 22 & 8 & 23 & 5 & 86 & 32 & 118 \\
\hline Column Percent & 42.2 & 34.3 & 43.8 & 35.0 & 37.3 & 42.1 & 39.7 & 27.8 & 40.4 & 34.8 & 38.7 \\
\hline $\begin{array}{l}\text { 3) } 1 \text { drive my own vehicle as part of my job } \\
\text { somet imes. }\end{array}$ & 9 & 3 & 2 & 4 & 9) & 3 & 6 & 1 & 26 & 11 & 37 \\
\hline Column Percent & 14.1 & 8.6 & 6.3 & 20.0 & 15.3 & 15.8 & 10.3 & 5.6 & 12.2 & 12.0 & 12.1 \\
\hline $\begin{array}{l}\text { 4) I drive my own vehicle as part of my job } \\
\text { every day. }\end{array}$ & 7 & 4 & 4 & 2 & 11 & 4 & 10 & 3 & 32 & 13 & 45 \\
\hline Column Percent & 10.9 & 11.4 & 12.5 & 10.0 & 18.6 & 21.1 & 17.2 & 16.7 & 15.0 & 14.1 & 14.8 \\
\hline $\begin{array}{l}\text { 5) I drive another vehicle as part of my job } \\
\text { somet imes. }\end{array}$ & 6 & 3 & 1 & 2 & 2 & 1 & 7 & 3 & 16 & 9 & 25 \\
\hline Column Percent & 9.4 & 8.6 & 3.1 & 10.0 & 3.4 & 5.3 & 12.1 & 16.7 & 7.5 & 9.8 & 8.2 \\
\hline $\begin{array}{l}\text { 6) I drive another vehicle as part of my job } \\
\text { every day. }\end{array}$ & 4 & 5 & 4 & $\cdots$ & 2 & 2 & 6 & 1 & 16 & 8 & 24 \\
\hline Column Percent & 6.3 & 14.3 & 12.5 & $\cdots$ & 3.4 & 10.5 & 10.3 & 5.6 & 7.5 & 8.7 & 7.9 \\
\hline Total & 64 & 35 & 32 & 20 & 59 & 19 & 58 & 18 & 213 & 92 & 305 \\
\hline
\end{tabular}


Effects of Administrative License Revocation on Employment Freguency Tables by State of fender Yype, and Total
Q121 ) IF YOU ARE NOT STILL WORKING AT THIS JOB, WHY DID YOU LEAVE?

\begin{tabular}{|c|c|c|c|c|c|c|c|c|c|c|c|c|}
\hline & & \multicolumn{8}{|c|}{ STATE } & \multirow{2}{*}{\multicolumn{2}{|c|}{ Total }} & \multirow[b]{4}{*}{ Total } \\
\hline & & \multicolumn{2}{|c|}{ Pennsylvania } & \multicolumn{2}{|c|}{ Maryland } & \multicolumn{2}{|c|}{ California } & \multicolumn{2}{|c|}{ Del aware } & & & \\
\hline & & \multicolumn{2}{|c|}{ OFFENDER TYPE } & \multicolumn{2}{|c|}{ OFFENDER TYPE } & \multicolumn{2}{|c|}{ OFFENDER TYPE } & \multicolumn{2}{|c|}{ OFFENDER TYPE } & \multicolumn{2}{|c|}{ OFFENDER TYPE } & \\
\hline & & First & Multiple & First & Multiple & First & Multiple & First & Multiple & First & Multiple & \\
\hline \multicolumn{2}{|l|}{ RESPONSE } & & & & & & & & & & & \\
\hline \multirow[t]{2}{*}{ 01) Better opportunity } & & 19 & 2 & 10 & 5 & 23 & 5 & 7 & 6 & 59 & 18 & 77 \\
\hline & Column Percent & 42.2 & 9.1 & 43.5 & 38.5 & 51.1 & 41.7 & 22.6 & 46.2 & 41.0 & 30.0 & 37.7 \\
\hline \multirow[t]{2}{*}{ 02) Layoff/termination } & & 6 & 5 & 5 & 3 & 7 & -- & 8 & 2 & 26 & 10 & 36 \\
\hline & Col umn Percent & 13.3 & 22.7 & 21.7 & 23.1 & 15.6 & $\cdots$ & 25.8 & 15.4 & 18.1 & 16.7 & 17.6 \\
\hline \multirow[t]{2}{*}{ 03) Medical/disability } & & -- & -- & $\cdots$ & 1 & $\cdots$ & $\cdots$ & 3 & $\cdots$ & 3 & 1 & 4 \\
\hline & Column Percent & $\cdots$ & -- & -- & 7.7 & $\cdots$ & -- & 9.7 & $\cdots$ & 2.1 & 1.7 & 2.0 \\
\hline \multicolumn{2}{|l|}{ 04) DUI/loss of license } & 3 & 6 & 1 & 2 & 3 & 4 & 2 & 3 & 9 & 15 & 24 \\
\hline & Colum Percent & 6.7 & 27.3 & 4.3 & 15.4 & 6.7 & 33.3 & 6.5 & 23.1 & 6.3 & 25.0 & 11.8 \\
\hline \multirow[t]{2}{*}{ 05) Relocation } & & 2 & 2 & 1 & -- & 6 & 2 & 1 & $\cdots$ & 10 & 4 & 14 \\
\hline & Column Percent & 4.4 & 9.1 & 4.3 & $\cdots$ & 13.3 & 16.7 & 3.2 & -- & 6.9 & 6.7 & 6.9 \\
\hline \multicolumn{2}{|c|}{ 06) Resignation/unsatisfactory job conditions } & 5 & 3 & 1 & -- & 5 & 1 & 3 & 2 & 14 & 6 & 20 \\
\hline & Column Percent & 11.1 & 13.6 & 4.3 & -- & 11.1 & 8.3 & 9.7 & 15.4 & 9.7 & 10.0 & 9.8 \\
\hline \multirow[t]{2}{*}{ 07) Return to school } & & 6 & 1 & 2 & 1 & $\therefore$ & -- & 3 & -- & 11 & 2 & 13 \\
\hline & Column Percent & 13.3 & 4.5 & 8.7 & 7.7 & $\cdots$ & -- & 9.7 & -- & 7.6 & 3.3 & 6.4 \\
\hline \multicolumn{2}{|c|}{ 08) End of temporary job } & 3 & 3 & 3 & 1 & 1 & -- & 1. & -- & 8 & 4 & 12 \\
\hline & Column Percent & 6.7 & 13.6 & 13.0 & 7.7 & 2.2 & $\cdots$ & 3.2 & $\because$ & 5.6 & 6.7 & 5.9 \\
\hline \multirow[t]{2}{*}{ 09) Retired } & & $\cdots$ & $\cdots$ & -- & $\cdots$ & $\cdots$ & -- & 1 & $\cdots$ & 1 & $\cdots$ & 1 \\
\hline & Column Percent & -- & -- & -- & -- & $\cdots$ & $\cdots$ & 3.2 & -- & 0.7 & $\cdots$ & 0.5 \\
\hline \multirow[t]{2}{*}{ 10) Bankrupcy } & & 1 & $\cdots$ & $\cdots$ & $\cdots$ & -- & $\cdots$ & 1 & -- & 2 & $\cdots$ & 2 \\
\hline & Column Percent & 2.2 & -- & $\cdots$ & $-\infty$ & -- & $\cdots$ & 3.2 & $\cdots$ & 1.4 & $\cdots$ & 1.0 \\
\hline \multirow[t]{2}{*}{ 11) Military service } & & $\cdots$ & $\cdots$ & $\therefore$ & $\cdots$ & -- & $\cdots$ & 1 & $\cdots$ & 1 & $\cdots$ & 1 \\
\hline & Column Percent & $\cdots$ & $\cdots$ & $\cdots$ & $\cdots$ & -- & -- & 3.2 & $\cdots$ & 0.7 & -- & 0.5 \\
\hline \multicolumn{2}{|l|}{ Total } & 45 & 22 & 23 & 13 & 45 & 12 & 31 & 13 & 144 & 60 & 204 \\
\hline
\end{tabular}


Freguency Tables by State Offender TYRe, and Total
Q13) WERE YOU EMPLOYED AT YHE YIME OF YOUR MOST RECENT DUI ARREST?

\begin{tabular}{|c|c|c|c|c|c|c|c|c|c|c|c|c|}
\hline & & \multicolumn{8}{|c|}{ STATE } & \multirow{2}{*}{\multicolumn{2}{|c|}{ Total }} & \multirow[b]{4}{*}{ Totạl } \\
\hline & & \multirow{2}{*}{\multicolumn{2}{|c|}{$\begin{array}{l}\text { Pennsylvania } \\
\text { OFFENDER TYPE }\end{array}$}} & \multirow{2}{*}{\multicolumn{2}{|c|}{$\frac{\text { Maryland }}{\text { OFFENDER TYPE }}$}} & \multirow{2}{*}{\multicolumn{2}{|c|}{$\begin{array}{l}\text { California } \\
\text { OFFENDER TYPE }\end{array}$}} & \multicolumn{2}{|c|}{ Delaware } & & & \\
\hline & & & & & & & & OFFENDE & R TYPE & OFFENDE & R TYPE & \\
\hline & & First & Multiple & First & Mult iple & First & Multiple & First & Multiple & First & Mul tiple & \\
\hline \multicolumn{2}{|c|}{ RESPONSE } & \multirow[b]{2}{*}{145} & \multirow[b]{2}{*}{55} & \multirow[b]{2}{*}{85} & \multirow[b]{2}{*}{32} & \multirow[b]{2}{*}{153} & \multirow[b]{2}{*}{70} & \multirow[b]{2}{*}{125} & \multirow[b]{2}{*}{43.} & \multirow[b]{2}{*}{508} & \multirow[b]{2}{*}{200} & \multirow[b]{2}{*}{708} \\
\hline les & & & & & & & & & & & & \\
\hline & Column Percent & 89.5 & 90.2 & 92.4 & 88.9 & 93.9 & 90.9 & 93.3 & 93.5 & 92.2 & 90.9 & 91.8 \\
\hline \multirow[t]{2}{*}{ to } & & 17 & 6 & 7 & 4 & 10 & 7 & 9 & 3 & 43 & 20 & 63 \\
\hline & Colum Percent & 10.5 & 9.8 & 7.6 & 11.1 & 6.1 & 9.1 & 6.7 & 6.5 & 7.8 & 9.1 & 8.2 \\
\hline \multicolumn{2}{|c|}{ Total } & 162 & 61 & 92 & 36 & 163 & 77 & 134 & 46 & 551 & 220 & 771 \\
\hline
\end{tabular}


Effects of Administrative License Revocation on Employment

Q14) HOW WOULD YOU RATE YOUR OVERALL SATSFACTION GITH THE JOB YOU HELb AT THE TIME OF YOUR MOST RECENT DUI ARREST?

\begin{tabular}{|c|c|c|c|c|c|c|c|c|c|c|c|c|}
\hline & & \multicolumn{8}{|c|}{ STATE } & \multirow{2}{*}{\multicolumn{2}{|c|}{ Total }} & \multirow[b]{4}{*}{ Total } \\
\hline & & \multicolumn{2}{|c|}{ Pennsylvania } & \multicolumn{2}{|c|}{ Maryland } & \multicolumn{2}{|c|}{ Cal ifornia } & \multicolumn{2}{|c|}{ Delaware } & & & \\
\hline & & \multicolumn{2}{|c|}{ OFFENDER TYPE } & \multicolumn{2}{|c|}{ OFFENDER TYPE } & \multicolumn{2}{|c|}{ OF FENDER TYPE } & \multicolumn{2}{|c|}{ OFFENDER TYPE } & \multicolumn{2}{|c|}{ OFFENDER TYPE } & \\
\hline & & First & Multiple & First & Muttiple & First & Multiple & First & Multiple & First & Multiple & \\
\hline \multicolumn{2}{|c|}{ RESPONSE CATEGORY } & \multirow[b]{2}{*}{8} & \multirow[b]{2}{*}{7} & \multirow[b]{2}{*}{13} & \multirow[b]{2}{*}{3} & \multirow[b]{2}{*}{15} & \multirow[b]{2}{*}{6} & \multirow[b]{2}{*}{11} & \multirow[b]{2}{*}{6} & \multirow[b]{2}{*}{47} & \multirow[b]{2}{*}{22} & \multirow[b]{2}{*}{69} \\
\hline Dissat isfied & & & & & & & & & & & & \\
\hline & Colum Percent & 6.3 & 15.2 & 16.0 & 10.0 & 10.6 & 9.8 & 9.6 & 15.0 & 10.1 & 12.4 & 10.7 \\
\hline \multirow[t]{2}{*}{ Neutral } & & 15 & 12 & 10 & 9 & 18 & 11 & 15 & 4 & 58 & 36 & 94 \\
\hline & Column Percent & 11.7 & 26.1 & 12.3 & 30.0 & 12.8 & 18.0 & 13.0 & 10.0 & 12.5 & 20.3 & 14.6 \\
\hline \multirow[t]{2}{*}{ Sat isfied } & & 105 & 27 & 58 & 18 & 108 & 44 & 89 & 30 & 360 & 119 & 479 \\
\hline & Column Percent & 82.0 & 58.7 & 71.6 & 60.0 & 76.6 & 72.1 & 77.4 & 75.0 & 77.4 & 67.2 & 74.6 \\
\hline \multicolumn{2}{|l|}{ Total } & 128 & 46 & 81 & 30 & 141 & 61 & 115 & 40 & 465 & 177 & 642 \\
\hline
\end{tabular}


Effects of Administrative License Revocation on Employment

Freguency Jables by State Questionnaire and Total

Q15) Frequency Tables by State Of Yender Type and Total

\begin{tabular}{|c|c|c|c|c|c|c|c|c|c|c|c|c|}
\hline & & \multicolumn{8}{|c|}{ STATE } & \multirow{2}{*}{\multicolumn{2}{|c|}{ Total }} & \multirow[b]{4}{*}{ Total } \\
\hline & & \multicolumn{2}{|c|}{ Pennsylvania } & \multicolumn{2}{|c|}{ Maryl and } & \multicolumn{2}{|c|}{ Cal ifornia } & \multicolumn{2}{|c|}{ Delaware } & & & \\
\hline & & \multicolumn{2}{|c|}{ OFFENDER TYPE } & \multicolumn{2}{|c|}{ OFFENDER TYPE } & \multicolumn{2}{|c|}{ OFFENDER TYPE } & \multicolumn{2}{|c|}{ OFFENDER TYPE } & \multicolumn{2}{|c|}{ OFFENDER TYPE } & \\
\hline & & First & Multiple & First & Multiple & First & Multiple & First & Multiple & First & Mult iple & \\
\hline \multicolumn{13}{|c|}{ RESPONSE } \\
\hline \multirow[t]{2}{*}{ Yes } & & 20 & 14 & 13 & 13 & 34 & 23 & 10 & 6 & 77 & 56 & 133 \\
\hline & Column Percent & 14.7 & 28.0 & 15.7 & 39.4 & 24.1 & 35.4 & 8.7 & 15.0 & 16.2 & 29.8 & 20.1 \\
\hline \multirow[t]{2}{*}{ गo } & & 116 & 36 & 70 & 20 & 107 & 42 & 105 & 34 & 398 & 132 & 530 \\
\hline & Column Percent & 85.3 & 72.0 & 84.3 & 60.6 & 75.9 & 64.6 & 91.3 & 85.0 & 83.8 & 70.2 & 79.9 \\
\hline \multicolumn{2}{|c|}{ Total } & 136 & 50 & 83 & 33 & 141 & 65 & 115 & 40 & 475 & 188 & 663 \\
\hline
\end{tabular}


Effects of Administrative License Revocation on Employment Frequency Tabl es by State, of fender TYpe and Total
Q16) DOES/6ID YOUR EMPLOYER'KNOW ABOUT YOUK DUI ARREST?

\begin{tabular}{|c|c|c|c|c|c|c|c|c|c|c|c|c|}
\hline & & \multicolumn{8}{|c|}{ STATE } & \multirow{2}{*}{\multicolumn{2}{|c|}{ Total }} & \multirow[b]{4}{*}{ Total } \\
\hline & & \multicolumn{2}{|c|}{ Pennsylvania } & \multicolumn{2}{|c|}{ Maryland } & \multicolumn{2}{|c|}{ Cal ifornia } & \multicolumn{2}{|c|}{ Delaware } & & & \\
\hline & & \multicolumn{2}{|c|}{ OFFENDER TYPE } & \multicolumn{2}{|c|}{ OFFENDER TYPE } & \multicolumn{2}{|c|}{ OFFENDER TYPE } & \multicolumn{2}{|c|}{ OFFENDER TYPE } & \multicolumn{2}{|c|}{ OFFENDER TYPE } & \\
\hline & & First & Mul tiple & First & Mult iple & First & Multiple & First & Multiple & First & Multiple & \\
\hline \multicolumn{2}{|c|}{ ،ESPONSE } & \multirow[b]{2}{*}{87} & \multirow[b]{2}{*}{32} & \multirow[b]{2}{*}{46} & \multirow[b]{2}{*}{17} & \multirow[b]{2}{*}{62} & \multirow[b]{2}{*}{28} & \multirow[b]{2}{*}{74} & \multirow[b]{2}{*}{26} & \multirow[b]{2}{*}{269} & \multirow[b]{2}{*}{103} & \multirow[b]{2}{*}{372} \\
\hline 'es & & & & & & & & & & & & \\
\hline & Column Percent & 74.4 & 84.2 & 65.7 & 85.0 & 55.9 & 62.2 & 71.2 & 76.5 & 66.9 & 75.2 & 69.0 \\
\hline \multirow[t]{2}{*}{ do } & & 30 & 6 & 24 & 3 & 49 & 17 & 30 & 8 & 133 & 34 & 167 \\
\hline & Column Percent & 25.6 & 15.8 & 34.3 & 15.0 & 44.1 & 37.8 & 28.8 & 23.5 & 33.1 & 24.8 & 31.0 \\
\hline \multicolumn{2}{|c|}{ jotal } & 117 & 38 & 70 & 20 & 111 & 45 & 104 & 34 & 402 & 137 & 539 \\
\hline
\end{tabular}


Effects of Administrative License Revocation on Employment

Freguency Tables by State Offender Type and Total
Q17) HOW DID YOUR EMPLOYER FIND OUT ABOUT YOUR DUI ARREST?

\begin{tabular}{|c|c|c|c|c|c|c|c|c|c|c|c|}
\hline \multirow[t]{4}{*}{. } & \multicolumn{8}{|c|}{ STATE } & \multirow{2}{*}{\multicolumn{2}{|c|}{ Total }} & \multirow[b]{4}{*}{ Total } \\
\hline & \multicolumn{2}{|c|}{ Pennsylvania } & \multicolumn{2}{|c|}{ Maryland } & \multicolumn{2}{|c|}{ Cal ifornia } & \multicolumn{2}{|c|}{ Delaware } & & & \\
\hline & \multicolumn{2}{|c|}{ OFFENDER TYPE } & \multicolumn{2}{|c|}{ OFFENDER TYPE } & \multicolumn{2}{|c|}{ OFFENDER TYPE } & \multicolumn{2}{|c|}{ OFFENDER TYPE } & \multicolumn{2}{|c|}{ OFFENDER TYPE } & \\
\hline & First & Multiple & First & Mutt iple & First & Multiple & first & Mult tiple & First & Multiple & \\
\hline 'ESPONSE & \multirow[b]{2}{*}{78} & \multirow[b]{2}{*}{26} & \multirow[b]{2}{*}{37} & \multirow[b]{2}{*}{15} & \multirow[b]{2}{*}{58} & \multirow[b]{2}{*}{26} & \multirow[b]{2}{*}{70} & \multirow[b]{2}{*}{25} & \multirow[b]{2}{*}{243} & \multirow[b]{2}{*}{92} & \multirow[b]{2}{*}{335} \\
\hline ) I told my employer. & & & & & & & & & & & \\
\hline Column Percent & 88.6 & 81.3 & 78.7 & 83.3 & 93.5 & 92.9 & 93.3 & 96.2 & 89.3 & 88.5 & 89.1 \\
\hline \multirow[t]{2}{*}{ ) A co-worker told my } & 3 & 2 & -- & $-\cdot$ & 2 & 1 & 4 & $\cdots$ & 9 & 3 & 12 \\
\hline & 3.4 & 6.3 & $\cdots$ & $\cdots$ & 3.2 & 3.6 & 5.3 & $\cdots$ & 3.3 & 2.9 & 3.2 \\
\hline i) My employer read about it in the newspaper. & 6 & 2 & 3 & 1 & $\cdots$ & 1 & $\cdots$ & $\cdots$ & 9 & 4 & 13 \\
\hline Column Percent & 6.8 & 6.3 & 6.4 & 5.6 & $\cdots$ & 3.6 & $\cdots$ & $\because$ & 3.3 & 3.8 & 3.5 \\
\hline $\begin{array}{l}\text { i) The Department of Motor Vehicles not ified my } \\
\text { amployer. }\end{array}$ & $\cdots$ & 1 & 4 & 2 & 1 & $\cdots$ & -- & -- & 5 & 3 & 8 \\
\hline Column Percent & -- & 3.1 & 8.5 & 11.1 & 1.6 & $\cdots$ & $\cdots$ & -- & 1.8 & 2.9 & 2.1 \\
\hline \multirow[t]{2}{*}{$\Rightarrow$ other } & 1 & 1 & 3 & -- & 1 & $\cdots$ & 1 & 1 & 6 & 2 & 8 \\
\hline & 1.1 & 3.1 & 6.4 & $\cdots$ & 1.6 & $\cdots$ & 1.3 & 3.8 & 2.2 & 1.9 & 2.1 \\
\hline .otal & 88 & 32 & 47 & 18 & 62 & 28 & 75 & 26 & 272 & 104 & 376 \\
\hline
\end{tabular}


Freguency Tables by State of fender Type and Total
Q18) DOES/DID YOUR EMPLOYER (AT THE TIME OF YOUR DUI ARRES KNOW THAT YOU LOST YOUR LICENSE?

\begin{tabular}{|c|c|c|c|c|c|c|c|c|c|c|c|}
\hline & \multicolumn{8}{|c|}{ STATE } & \multirow{2}{*}{\multicolumn{2}{|c|}{ Total }} & \multirow[b]{4}{*}{ Total } \\
\hline \multirow{3}{*}{$\cdot$} & \multicolumn{2}{|c|}{ Pennsylvania } & \multicolumn{2}{|c|}{ Maryland } & \multicolumn{2}{|c|}{ Cal ifornia } & \multicolumn{2}{|c|}{ Delaware } & & & \\
\hline & \multicolumn{2}{|c|}{ OFFENDER TYPE } & \multicolumn{2}{|c|}{ OFFENDER TYPE } & \multicolumn{2}{|c|}{ OF FENDER TYPE } & \multicolumn{2}{|c|}{ OFFENDER TYPE } & \multicolumn{2}{|c|}{ OFFENDER TYPE } & \\
\hline & First & Multiple & First & Multiple & First & Multiple & First & Multiple & first & Multiple & \\
\hline \multicolumn{12}{|l|}{ RESPONSE } \\
\hline \multirow[t]{2}{*}{ 1) Yes } & 76 & 24 & 22 & 12 & 55 & 26 & 63 & 26 & 216 & 88 & 304 \\
\hline & 65.5 & 61.5 & 31.4 & 60.0 & 50.9 & 57.8 & 60.0 & 76.5 & 54.1 & 63.8 & 56.6 \\
\hline \multirow[t]{2}{*}{ 2) $\mathrm{No}$} & 29 & 9 & 14 & 4 & 49 & 17 & 33 & 8 & 125 & 38 & 163 \\
\hline & 25.0 & 23.1 & 20.0 & 20.0 & 45.4 & 37.8 & 31.4 & 23.5 & 31.3 & 27.5 & 30.4 \\
\hline 3) I have not yet lost my l icense. & 11 & 6 & 34 & 4 & 4 & 2 & 9 & $\cdots$ & 58 & 12 & 70 \\
\hline Column Percent & 9.5 & 15.4 & 48.6 & 20.0 & 3.7 & 4.4 & 8.6 & $\cdots$ & 14.5 & 8.7 & 13.0 \\
\hline Total & 116 & 39 & 70 & 20 & 108 & 45 & 105 & 34 & 399 & 138 & 537 \\
\hline
\end{tabular}


Effects of Administrative License Revocat ion on Employment

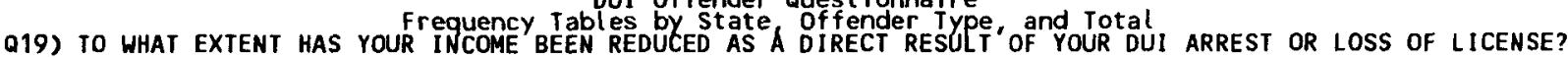

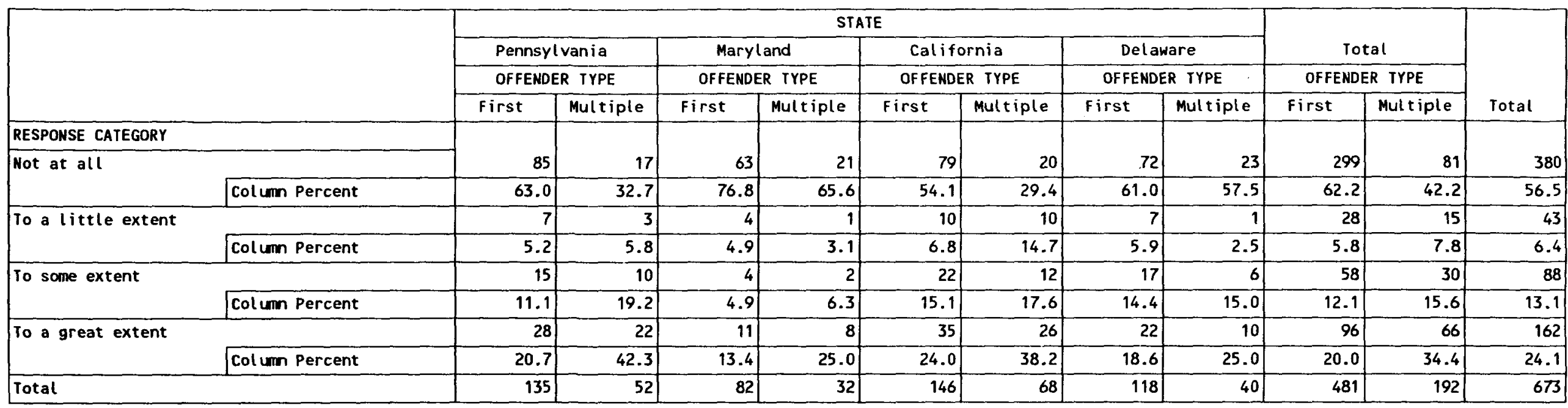


Effects of Administrative License Revocation on Employment

Q22) IN WHOSE NAME WAS THE VEHICLE YOU WERE DRIVING AT THE TIME GF YouR MOST RECENT DUI ARREST REGISTERED?

\begin{tabular}{|c|c|c|c|c|c|c|c|c|c|c|c|}
\hline & \multicolumn{8}{|c|}{ STATE } & \multirow{2}{*}{\multicolumn{2}{|c|}{ Total }} & \multirow[b]{4}{*}{ Total } \\
\hline & \multicolumn{2}{|c|}{ Pennsylvania } & \multicolumn{2}{|c|}{ Maryl and } & \multicolumn{2}{|c|}{ California } & \multicolumn{2}{|c|}{ Delaware } & & & \\
\hline & \multicolumn{2}{|c|}{ OFFENDER TYPE } & \multicolumn{2}{|c|}{ OFFENDER TYPE } & \multicolumn{2}{|c|}{ OFFENDER TYPE } & \multicolumn{2}{|c|}{ OFFENDER TYPE } & \multicolumn{2}{|c|}{ OFFENDER TYPE } & \\
\hline & First & Multiple & first & Multiple & First & Multiple & First & Mult iple & First & Mult iple & \\
\hline RESPONSE & \multirow[b]{2}{*}{121} & \multirow[b]{2}{*}{40} & \multirow[b]{2}{*}{70} & \multirow[b]{2}{*}{29} & \multirow[b]{2}{*}{137} & \multirow[b]{2}{*}{69} & \multirow[b]{2}{*}{98} & \multirow[b]{2}{*}{34} & \multirow[b]{2}{*}{426} & \multirow[b]{2}{*}{172} & \multirow[b]{2}{*}{598} \\
\hline 1) My own name & & & & & & & & & & & \\
\hline Column Percent & 72.0 & 61.5 & 72.9 & 80.6 & 81.1 & 84.1 & 68.5 & 72.3 & 74.0 & 74.8 & 74.2 \\
\hline 2) Spouse & 8 & 5 & 3 & 1 & 8 & 3 & 6 & 2 & 25 & 11 & 36 \\
\hline Column Percent & 4.8 & 7.7 & 3.1 & 2.8 & 4.7 & 3.7 & 4.2 & 4.3 & 4.3 & 4.8 & 4.5 \\
\hline 3) Relative (other than spouse) & 28 & 7 & 10 & 3 & 9 & -- & 18 & 6 & 65 & 16 & 81 \\
\hline Colum Percent & 16.7 & 10.8 & 10.4 & 8.3 & 5.3 & $\cdots$ & 12.6 & 12.8 & 11.3 & 7.0 & 10.0 \\
\hline 4) Friend (living in same household) & 2 & 5 & 3 & $\cdots$ & 2 & 2 & 4 & 2 & 11 & 9 & 20 \\
\hline Colum Percent & 1.2 & 7.7 & 3.1 & -- & 1.2 & 2.4 & 2.8 & 4.3 & 1.9 & 3.9 & 2.5 \\
\hline 5) Friend (not living in same household) & 5 & 2 & 5 & 3 & 4 & 4 & 8 & 3 & 22 & 12 & 34 \\
\hline Column Percent & 3.0 & 3.1 & 5.2 & 8.3 & 2.4 & 4.9 & 5.6 & 6.4 & 3.8 & 5.2 & 4.2 \\
\hline 6) Prior owner & -- & 1 & -- & -- & 3 & 1 & 4 & -- & 7 & 2 & 9 \\
\hline Column Percent & $\cdots$ & 1.5 & $-\cdot$ & $\cdots$ & 1.8 & 1.2 & 2.8 & -- & 1.2 & 0.9 & 1.1 \\
\hline 7) Employer & 4 & 4 & 1. & -- & 2 & 2 & 3 & $\cdots$ & 10 & 6 & 16 \\
\hline Column Percent & 2.4 & 6.2 & 1.0 & -- & 1.2 & 2.4 & 2.1 & $-\cdot$ & 1.7 & 2.6 & 2.0 \\
\hline 8) Rental car & $\cdots$ & $\cdots$ & 3 & $\cdots$ & 4 & 1 & 1 & -- & 8 & 1 & 9 \\
\hline Col umn Percent & $\cdots$ & -- & 3.1 & -- & 2.4 & 1.2 & 0.7 & -- & 1.4 & 0.4 & $1: 1$ \\
\hline 9) Other & $\cdots$ & 1 & 1 & -- & -- & $\cdots$ & 1 & $\cdots$ & 2 & 1 & 3 \\
\hline Column Percent & $\cdots$ & 1.5 & 1.0 & $\cdots$ & $\cdots$ & -- & 0.7 & -- & 0.3 & 0.4 & 0.4 \\
\hline Total & 168 & 65 & 96 & 36 & 169 & 82 & 143 & 47 & 576 & 230 & 806 \\
\hline
\end{tabular}


Freguency Tables by State Offender TYYe, and Total
Q23) WERE YOU WEARING YOUR SEAT BELT AT THE YYME' OF YOUR DUI ARREST?

\begin{tabular}{|c|c|c|c|c|c|c|c|c|c|c|c|c|}
\hline & & \multicolumn{8}{|c|}{ STATE } & \multirow{2}{*}{\multicolumn{2}{|c|}{ Total }} & \multirow[b]{4}{*}{ Total } \\
\hline & & \multicolumn{2}{|c|}{ Pennsylvania } & \multicolumn{2}{|c|}{ Maryl and } & \multicolumn{2}{|c|}{ California } & \multicolumn{2}{|c|}{ Delaware } & & & \\
\hline & & \multicolumn{2}{|c|}{ OFFENDER TYPE } & \multicolumn{2}{|c|}{ OFFENDER TYPE } & \multicolumn{2}{|c|}{ OF FENDER TYPE } & \multicolumn{2}{|c|}{ OFFENDER TYPE } & \multicolumn{2}{|c|}{ OFFENDER TYPE } & \\
\hline & & First & Multiple & First & Multiple & First & Multiple & First & Multiple & First & Multiple & \\
\hline \multicolumn{13}{|c|}{ RESPONSE } \\
\hline \multirow[t]{2}{*}{;es } & & 98 & 24 & 64 & 21 & 149 & 69 & 89 & 22 & 400 & 136 & 536 \\
\hline & Column Percent & 59.8 & 38.1 & 66.7 & 56.8 & 88.7 & 85.2 & 62.7 & 46.8 & 70.2 & 59.6 & 67.2 \\
\hline \multirow[t]{2}{*}{ vo } & & 66 & 39 & 32 & 16 & 19 & 12 & 53 & 25 & 170 & 92 & 262 \\
\hline & Columin Percent & 40.2 & 61.9 & 33.3 & 43.2 & 11.3 & 14.8 & 37.3 & 53.2 & 29.8 & 40.4 & 32.8 \\
\hline \multicolumn{2}{|l|}{ otal } & 164 & 63 & 96 & 37 & 168 & 81 & 142 & 47 & 570 & 228 & 798 \\
\hline
\end{tabular}


Effects of Administrative License Revocation on Employment

Freguency Tables by State Offender TYPe and Total
Q24) WHAT DID THE POLICE SAP WAS THE REASON FOR STOPPING YOUR VEHICLE WHEN THE DUI ARREST WAS MADE?

\begin{tabular}{|c|c|c|c|c|c|c|c|c|c|c|c|}
\hline & \multicolumn{8}{|c|}{ STATE } & \multirow{2}{*}{\multicolumn{2}{|c|}{ Total }} & \multirow[b]{4}{*}{ Total } \\
\hline & \multicolumn{2}{|c|}{ Pennsylvania } & \multicolumn{2}{|c|}{ Maryl and } & \multicolumn{2}{|c|}{ Cal ifornia } & \multicolumn{2}{|c|}{ Delaware } & & & \\
\hline \multirow[t]{2}{*}{. } & \multicolumn{2}{|c|}{ OFFENDER TYPE } & \multicolumn{2}{|c|}{ OFFENDER TYPE } & \multicolumn{2}{|c|}{ OFFENDER TYPE } & \multicolumn{2}{|c|}{ OFFENDER TYPE } & \multicolumn{2}{|c|}{ OFFENDER TYPE } & \\
\hline & First & Multiple & First & Mult iple & First & Multiple & First & Mul tiple & First & Multiple & \\
\hline RESPONSE & & & & & & & & & & & \\
\hline \multirow[t]{2}{*}{ Acc ident } & 44 & 14 & 13 & 6 & 18 & 9 & 27 & 9 & 102 & 38 & 140 \\
\hline & 26.2 & 21.9 & 13.5 & 16.2 & 10.7 & 11.0 & 19.1 & 19.1 & 17.8 & 16.5 & 17.4 \\
\hline Moving violation & 108 & 41 & 72 & 29 & 116 & 52 & 84 & 30 & 380 & 152 & 532 \\
\hline Column Percent & 64.3 & 64.1 & 75.0 & 78.4 & 68.6 & 63.4 & 59.6 & 63.8 & 66.2 & 66.1 & 66.2 \\
\hline $\begin{array}{l}\text { Vehicle violation (e.g.: expired inspection } \\
\text { sticker, tail light out, no headl ights) }\end{array}$ & 11 & 3 & 5 & 2 & 19 & 8 & 11 & 5 & 46 & 18 & 64 \\
\hline Column Percent & 6.5 & 4.7 & 5.2 & 5.4 & 11.2 & 9.8 & 7.8 & 10.6 & 8.0 & 7.8 & 8.0 \\
\hline Roadblock or sobriety checkpoint & 2 & 3 & 1 & -- & 7 & 4 & 8 & -- & 18 & 7 & 25 \\
\hline Column Percent & 1.2 & 4.7 & 1.0 & $\cdots$ & 4.1 & 4.9 & 5.7 & -- & 3.1 & 3.0 & 3.1 \\
\hline \multirow[t]{2}{*}{ other } & 3 & 3 & 5 & -- & 9 & 9 & 11 & 3 & 28 & 15 & 43 \\
\hline & 1.8 & 4.7 & 5.2 & -- & 5.3 & 11.0 & 7.8 & 6.4 & 4.9 & 6.5 & 5.3 \\
\hline Total & 168 & 64 & 96 & 37 & 169 & 82 & 141 & 47 & 574 & 230 & 804 \\
\hline
\end{tabular}


Effects of Administrative License Revocation on Employment

Q25) HOW FREQUENTLY IN THE YEAR BEFORE YOUR MOST RECENT DU ARR ARRS DYD YOU tONSUME $1-2$ 'YRERS/MIXED DRINKS/GLASSES WINE LESS THAN 1 HOUR BEFORE DRIVING?

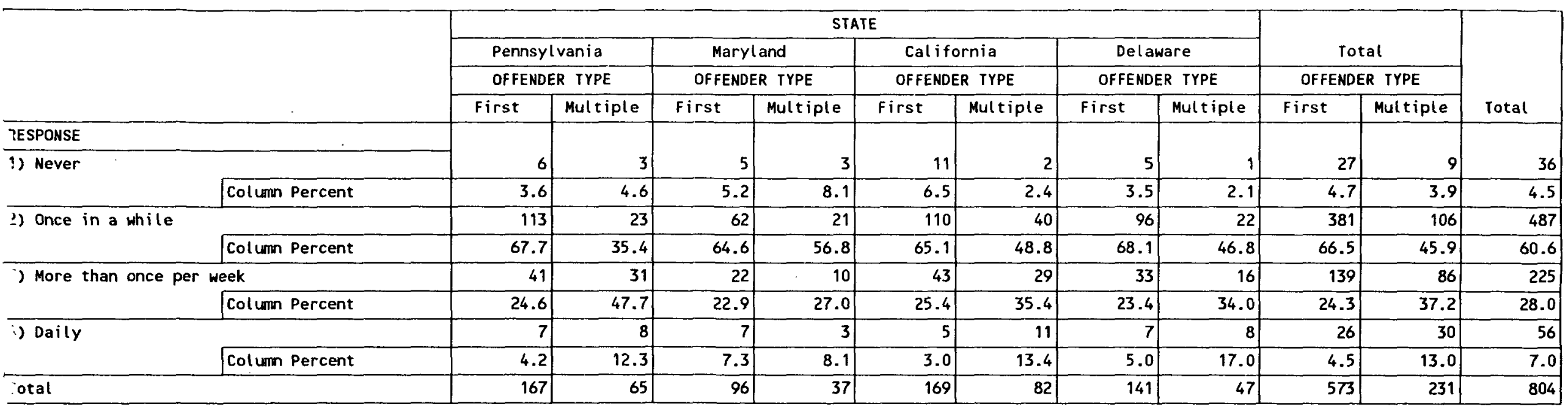


Effects of Administrative License Revocation on Employment

Q27) DID YOU TARE A BREATH TESY AT THE TIME OF YOUR hOST RECENT DUI ARREST?

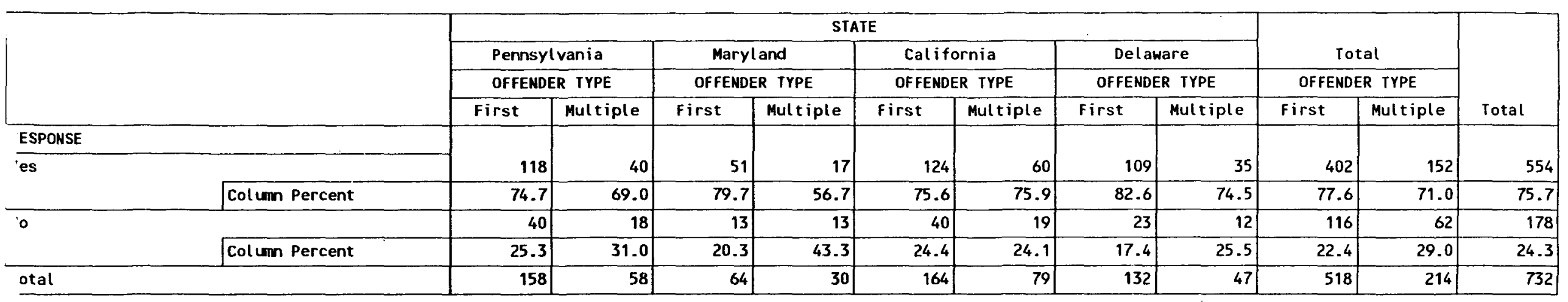

NOTE: This question was not asked of DUI offenders who had not lost their license. 
Effects of Administrative License Revocation on Empl oyment Freguency Tables by State offender TYpe and Total
Q28) WEKE YOU CHARGED WITH REFUSING AREATH TEST?

\begin{tabular}{|c|c|c|c|c|c|c|c|c|c|c|c|c|}
\hline & & \multicolumn{8}{|c|}{ STATE } & \multirow{2}{*}{\multicolumn{2}{|c|}{ Total }} & \multirow[b]{4}{*}{ Total } \\
\hline & & \multicolumn{2}{|c|}{ Pennsylvania } & \multicolumn{2}{|c|}{ Maryl and } & \multicolumn{2}{|c|}{ Cal i fornia } & \multicolumn{2}{|c|}{ Delaware } & & & \\
\hline & & \multicolumn{2}{|c|}{ OFFENDER TYPE } & \multicolumn{2}{|c|}{ OFFENDER TYPE } & \multicolumn{2}{|c|}{ OF FENDER TYPE } & \multicolumn{2}{|c|}{ OFFENDER TYPE } & \multicolumn{2}{|c|}{ OFFENDER TYPE } & \\
\hline & & First & Multiple & First & Mult iple & First & Mul tiple & First & Mul tiple & First & Multiple & \\
\hline \multicolumn{2}{|c|}{ RESPONSE } & \multirow[b]{2}{*}{3} & \multirow[b]{2}{*}{3} & \multirow[b]{2}{*}{11} & \multirow[b]{2}{*}{11} & \multirow[b]{2}{*}{5} & \multirow[b]{2}{*}{6} & \multirow[b]{2}{*}{2} & \multirow[b]{2}{*}{3} & \multirow[b]{2}{*}{21} & \multirow[b]{2}{*}{23} & \multirow[b]{2}{*}{44} \\
\hline Yes & & & & & & & & & & & & \\
\hline & Col umn Percent & 7.5 & 15.8 & 84.6 & 91.7 & 12.2 & 35.3 & 8.7 & 25.0 & 17.9 & 38.3 & 24.9 \\
\hline \multirow[t]{2}{*}{ No } & & 37 & 16 & 2 & 1 & 36 & 11 & 21 & 9 & 96 & 37 & 133 \\
\hline & Column Percent & 92.5 & 84.2 & 15.4 & 8.3 & 87.8 & 64.7 & 91.3 & 75.0 & 82.1 & 61.7 & 75.1 \\
\hline \multicolumn{2}{|c|}{ Total } & 40 & 19 & 13 & 12 & 41 & 17 & 23 & 12 & 117 & 60 & 177 \\
\hline
\end{tabular}


Effects of Administrative License Revocation on Employment

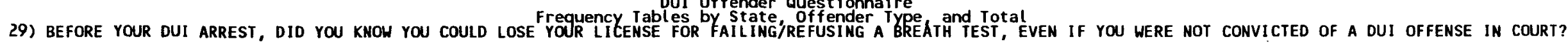

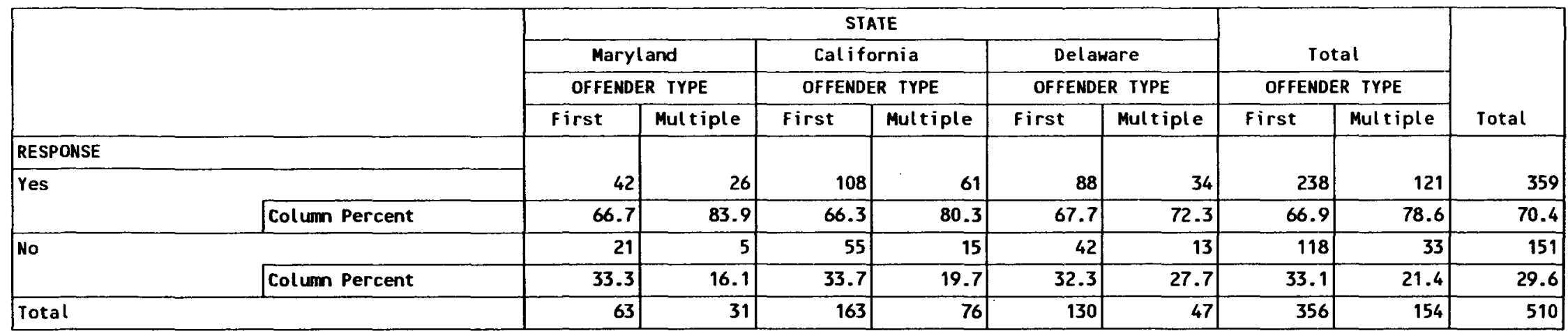


Q30) DID YOU REQUEST AN ADMINISTRATIVE HEARING WITH THE DEPARTMENT Of MOTOR VEHIYPeS WHEN YOU LOST YOUR LICENSE TO GET YOUR LICENSE BACK?

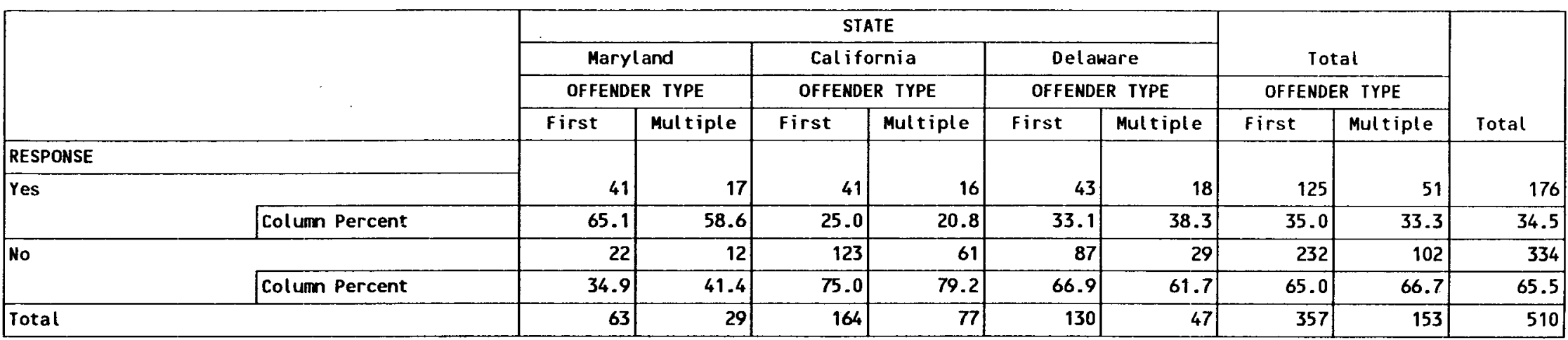


Freguency Tables by State, of fender TYYe, and Total

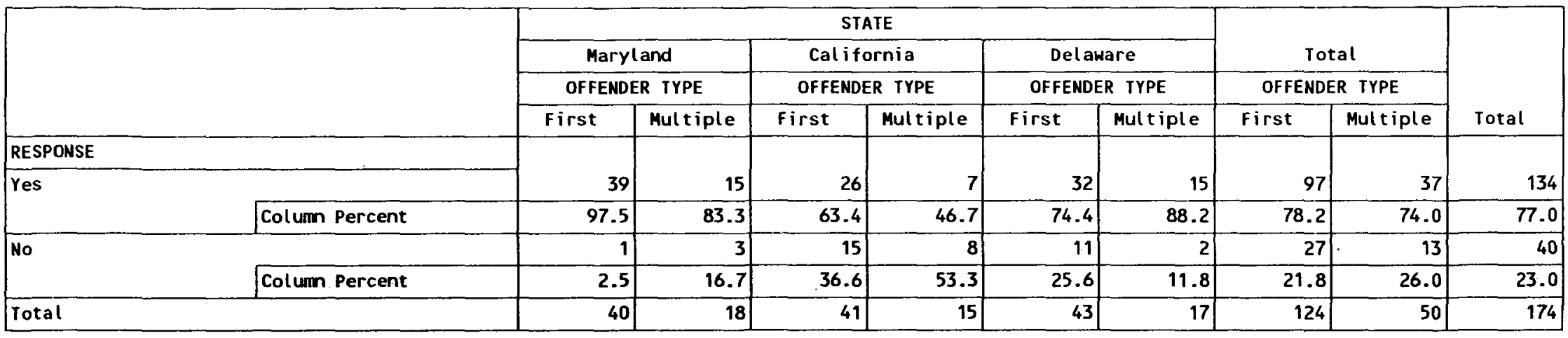

NOTE: This question was not asked of DUI of fenders who had not lost their license.

NOTE: This question was not asked in Pennsylvania since this state does not have Administrative License Revocation. 
Effects of Administrative License Revocation on Employment

Freguency Iables by State of fender Type and Total
Q32) DID THE ARRESTING POLICE ATTEND THE ADAINISTRATIVE HEARING?

\begin{tabular}{|c|c|c|c|c|c|c|c|c|c|c|}
\hline & & \multicolumn{6}{|c|}{ STATE } & \multirow{2}{*}{\multicolumn{2}{|c|}{ Total }} & \multirow[b]{4}{*}{ Total } \\
\hline & & \multicolumn{2}{|c|}{ Maryl and } & \multicolumn{2}{|c|}{ California } & \multicolumn{2}{|c|}{ Delaware } & & & \\
\hline & & \multicolumn{2}{|c|}{ OFFENDER TYPE } & \multicolumn{2}{|c|}{ OFFENDER TYPE } & \multicolumn{2}{|c|}{ OFFENDER TYPE } & \multicolumn{2}{|c|}{ OFFENDER TYPE } & \\
\hline & & First & Mul tiple & First & Multiple & First & Mult iple & First & Multiple & \\
\hline \multicolumn{2}{|c|}{ RESPONSE } & \multirow[b]{2}{*}{4} & \multirow[b]{2}{*}{8} & \multirow[b]{2}{*}{3} & \multirow[b]{2}{*}{2} & \multirow[b]{2}{*}{23} & \multirow[b]{2}{*}{12} & \multirow[b]{2}{*}{30} & \multirow[b]{2}{*}{22} & \multirow[b]{2}{*}{52} \\
\hline Yes & & & & & & & & & & \\
\hline & Column Percent & 9.8 & 47.1 & 7.3 & 15.4 & 54.8 & 70.6 & 24.2 & 46.8 & 30.4 \\
\hline \multirow[t]{2}{*}{ No } & & 37 & 9 & 38 & 11 & 19 & 5 & 94 & 25 & 119 \\
\hline & Column Percent & 90.2 & 52.9 & 92.7 & 84.6 & 45.2 & 29.4 & 75.8 & 53.2 & 69.6 \\
\hline \multicolumn{2}{|c|}{ Total } & 41 & 17 & 41 & 13 & 42 & 17 & 124 & 47 & 171 \\
\hline
\end{tabular}

NOTE: This question was not asked of DUI offenders who had not lost their license.

NOTE: This question was not asked in Pennsylvania since this state does not have Administrative License Revocation. 
Freguency Tables by State, Of fender Type, and Total
Q33) WHAT WAS THE RESULT OF' THE ADMINISTRATIVE HEARING?

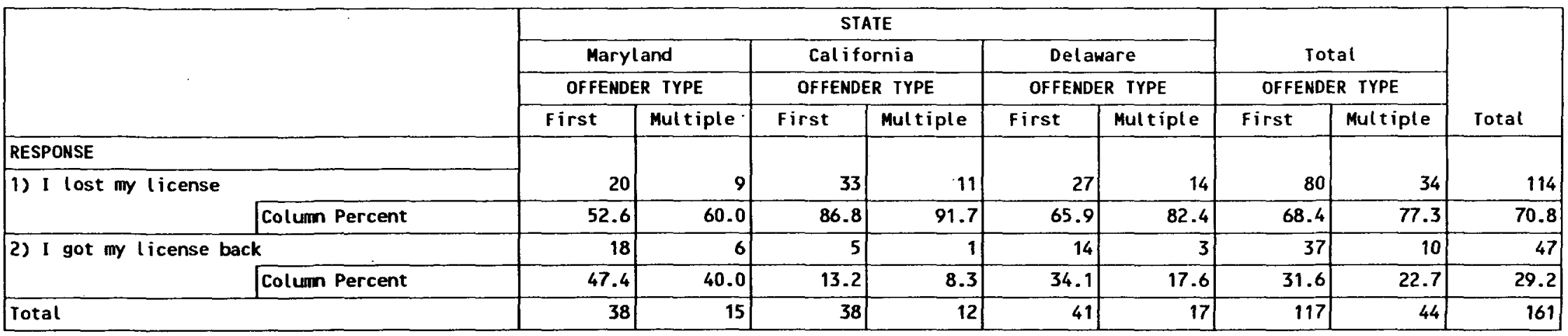

NOTE: This question was not asked of DUI of fenders who had not lost their license.

NOTE: This question was not asked in Pennsylvania since this state does not have Administrative License Revocation. 
Effects of Administrative License Revocation on Employment

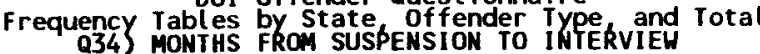

\begin{tabular}{|c|c|c|c|c|c|c|c|c|c|c|c|c|}
\hline & & \multicolumn{8}{|c|}{ STATE } & \multirow{2}{*}{\multicolumn{2}{|c|}{ Total }} & \multirow[b]{4}{*}{ Total } \\
\hline & & \multicolumn{2}{|c|}{ Pennsylvania } & \multicolumn{2}{|c|}{ Maryl and } & \multicolumn{2}{|c|}{ Cal ifornia } & \multicolumn{2}{|c|}{ Delaware } & & & \\
\hline & & \multicolumn{2}{|c|}{ OFFENDER TYPE } & \multicolumn{2}{|c|}{ OFFENDER TYPE } & \multicolumn{2}{|c|}{ OF FENDER TYPE } & \multicolumn{2}{|c|}{ OFFENDER TYPE } & \multicolumn{2}{|c|}{ OFFENDER TYPE } & \\
\hline & & First & Multiple & First & Mult iple & First & Multiple & First & Mult iple & First & Multiple & \\
\hline RESPONSE CATEGORY & & \multirow[b]{2}{*}{27} & \multirow[b]{2}{*}{5} & \multirow[b]{2}{*}{4} & \multirow[b]{2}{*}{2} & \multirow[b]{2}{*}{7} & \multirow[b]{2}{*}{--} & \multirow[b]{2}{*}{1} & \multirow[b]{2}{*}{$\cdots$} & \multirow[b]{2}{*}{39} & \multirow[b]{2}{*}{7} & \multirow[b]{2}{*}{46} \\
\hline Have not lost license & & & & & & & & & & & & \\
\hline & Column Percent & 17.5 & 8.8 & 9.1 & 8.0 & 4.4 & -- & 0.8 & -- & 8.1 & 3.5 & 6.8 \\
\hline \multirow[t]{2}{*}{3 months or less } & & 67 & 9 & 11 & 10 & 92 & 18 & 57 & 1 & 227 & 38 & 265 \\
\hline & Column Percent & 43.5 & 15.8 & 25.0 & 40.0 & 57.9 & 24.7 & 46.7 & 2.3 & 47.4 & 19.2 & 39.1 \\
\hline \multirow[t]{2}{*}{ Between 4 and 6 months } & & 16 & 13 & 12 & 3 & 35 & 19 & 27 & 5 & 90 & 40 & 130 \\
\hline & Column Percent & 10.4 & 22.8 & 27.3 & 12.0 & 22.0 & 26.0 & 22.1 & 11.6 & 18.8 & 20.2 & 19.2 \\
\hline \multirow[t]{2}{*}{ More than 6 months } & & 44 & 30 & 17 & 10 & 25 & 36 & 37 & 37. & 123 & 113 & 236 \\
\hline & Column Percent & 28.6 & 52.6 & 38.6 & 40.0 & 15.7 & 49.3 & 30.3 & 86.0 & 25.7 & 57.1 & 34.9 \\
\hline Total & & 154 & 57 & 44 & 25 & 159 & 73 & 122 & 43 & 479 & 198 & 677 \\
\hline
\end{tabular}


Effects of Administrative License Revocation on Employment

Frequency Tables by State, offender Type and Total
Q35) HOW LONG WILL (OR DID) THIS MOST RECENT DUI LICENSE SUSENSION/REVOCATION LAST? (IN DAYS)

\begin{tabular}{|c|c|c|c|c|c|c|c|c|c|c|c|c|}
\hline & & \multicolumn{8}{|c|}{ STATE } & \multirow{2}{*}{\multicolumn{2}{|c|}{ Total }} & \multirow[b]{4}{*}{ Total } \\
\hline & & \multicolumn{2}{|c|}{ Pennsylvania } & \multicolumn{2}{|c|}{ Maryl and } & \multicolumn{2}{|c|}{ California } & \multicolumn{2}{|c|}{ Delaware } & & & \\
\hline & & \multicolumn{2}{|c|}{ OFFENDER TYPE } & \multicolumn{2}{|c|}{ OFFENDER TYPE } & \multicolumn{2}{|c|}{ OFFENDER TYPE } & \multicolumn{2}{|c|}{ OFFENDER TYPE } & \multicolumn{2}{|c|}{ OFFENDER TYPE } & \\
\hline & & First & Multiple & First & Mult tiple & First & Multiple & First & Multiple & First & Mul tiple & \\
\hline \multicolumn{13}{|l|}{ RESPONSE CATEGORY } \\
\hline \multirow[t]{2}{*}{.ess than 1 month } & & -- & $\cdots$ & 4 & 1 & -- & -- & -- & -- & 4. & 1 & 5 \\
\hline & Column Percent & $\cdots$ & $\cdots$ & 9.1 & 4.5 & -- & $\cdots$ & -- & $\cdots$ & 0.9 & 0.5 & 0.8 \\
\hline \multirow[t]{2}{*}{ 3etween 1 and 3 months } & & 61 & $\cdots$ & 18 & 2 & 7 & $\cdots$ & 2 & -- & 88 & 2 & 90 \\
\hline & Column Percent & 39.6 & -- & 40.9 & 9.1 & 4.5 & -- & 1.7 & -- & 18.8 & 1.0 & 13.5 \\
\hline \multirow[t]{2}{*}{ 3etween 3 and 12 months } & & 84 & 44 & 20 & 16 & 140 & 33 & 88 & 26 & 332 & 119 & 451 \\
\hline & Column Percent & 54.5 & $74: 6$ & 45.5 & 72.7 & 90.9 & .44 .6 & 75.9 & 61.9 & 70.9 & 60.4 & 67.8 \\
\hline \multirow[t]{2}{*}{ More than 1 year } & & 9 & 15 & 2 & 3 & 7 & 41 & 26 & 16 & 44 & 75 & 119 \\
\hline & Column Percent & 5.8 & 25.4 & 4.5 & 13.6 & 4.5 & 55.4 & 22.4 & 38.1 & 9.4 & 38.1 & 17.9 \\
\hline Total & & 154 & 59 & 44 & 22 & 154 & 74 & 116 & 42 & 468 & 197 & 665 \\
\hline
\end{tabular}




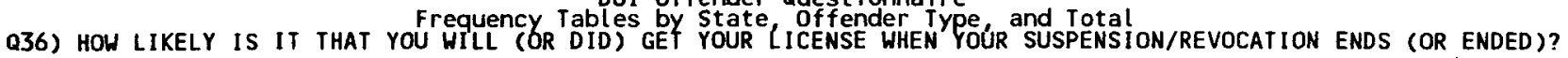

\begin{tabular}{|c|c|c|c|c|c|c|c|c|c|c|c|c|}
\hline & & \multicolumn{8}{|c|}{ STATE } & \multirow{2}{*}{\multicolumn{2}{|c|}{ Total }} & \multirow[b]{4}{*}{ Total } \\
\hline & & \multicolumn{2}{|c|}{ Pennsylvania } & \multicolumn{2}{|c|}{ Maryl and } & \multicolumn{2}{|c|}{ California } & \multicolumn{2}{|c|}{ Delaware } & & & \\
\hline & & \multicolumn{2}{|c|}{ OFFENDER TYPE } & \multicolumn{2}{|c|}{ OFFENDER TYPE } & \multicolumn{2}{|c|}{ OF FENDER TYPE } & \multicolumn{2}{|c|}{ OFFENDER TYPE } & \multicolumn{2}{|c|}{ OFFENDER TYPE } & \\
\hline & & First & Multiple & First & Multiple & First & Multiple & First & Multiple & First & Multiple & \\
\hline \multicolumn{2}{|l|}{ RESPONSE CATEGORY } & \multirow[b]{2}{*}{10} & \multirow[b]{2}{*}{6} & \multirow[b]{2}{*}{$\cdots$} & \multirow[b]{2}{*}{3} & \multirow[b]{2}{*}{10} & \multirow[b]{2}{*}{8} & \multirow[b]{2}{*}{10} & \multirow[b]{2}{*}{2} & \multirow[b]{2}{*}{30} & \multirow[b]{2}{*}{19} & \multirow[b]{2}{*}{49} \\
\hline Yot at All Likely & & & & & & & & & & & & \\
\hline & Col umn Percent & 6.6 & 10.9 & $\cdots$ & 12.5 & 6.5 & 10.7 & 8.1 & 4.5 & 6.4 & 9.6 & 7.3 \\
\hline \multirow[t]{2}{*}{ Inlikely } & & 5 & 1 & 1 & 1 & $\cdots$ & 3 & $-\cdot$ & 1 & 6 & 6 & 12 \\
\hline & Column Percent & 3.3 & 1.8 & 2.4 & 4.2 & $\cdots$ & 4.0 & -- & 2.3 & 1.3 & 3.0 & 1.8 \\
\hline \multirow[t]{2}{*}{ Somewhat likely } & & 7 & 4 & 3 & 9 & 7 & 7 & 5 & 6 & 22 & 26 & 48 \\
\hline & Column Percent & 4.6 & 7.3 & 7.3 & 37.5 & 4.5 & 9.3 & 4.1 & 13.6 & 4.7 & 13.1 & 7.2 \\
\hline \multirow[t]{2}{*}{ Jery likely } & & 129 & 44 & 37 & 11 & 138 & 57 & 108 & 35 & 412 & 147 & 559 \\
\hline & Colum Percent & 85.4 & 80.0 & 90.2 & 45.8 & 89.0 & 76.0 & 87.8 & 79.5 & 87.7 & 74.2 & 83.7 \\
\hline \multicolumn{2}{|l|}{ otal } & 151 & 55 & 41 & 24 & 155 & 75 & 123 & 44 & 470 & 198 & 668 \\
\hline
\end{tabular}


Freguency Tables by State of fender TyPe, and Total
037) HOW LIKELY IS IT THAT YOU WILL ORIVE WHILE YOU DON'T HAVE A LICENSE?

\begin{tabular}{|c|c|c|c|c|c|c|c|c|c|c|c|c|}
\hline & & \multicolumn{8}{|c|}{ STATE } & \multirow{2}{*}{\multicolumn{2}{|c|}{ Total }} & \multirow[b]{4}{*}{ Total } \\
\hline & & \multicolumn{2}{|c|}{ Pennsylvania } & \multicolumn{2}{|c|}{ Maryland } & \multicolumn{2}{|c|}{ California } & \multicolumn{2}{|c|}{ Del aware } & & & \\
\hline & & \multicolumn{2}{|c|}{ OFFENDER TYPE } & \multicolumn{2}{|c|}{ OFFENDER TYPE } & \multicolumn{2}{|c|}{ OFFENDER TYPE } & \multicolumn{2}{|c|}{ OFFENDER TYPE } & \multicolumn{2}{|c|}{ OFFENDER TYPE } & \\
\hline & & First & Multiple & first & Mult iple & First & Mul tiple & First & Multiple & First & Multiple & \\
\hline \multicolumn{13}{|l|}{ RESPONSE CATEGORY } \\
\hline \multirow[t]{2}{*}{ Not at All Likely } & & 115 & 32 & 26 & 16 & 55 & 14 & 70 & 27 & 266 & 89 & 355 \\
\hline & Col umn Percent & 73.2 & 55.2 & 59.1 & 57.1 & 35.7 & 18.7 & 56.9 & 60.0 & 55.6 & 43.2 & 51.9 \\
\hline \multirow[t]{2}{*}{ Unl ikely } & & 10 & 7 & 3 & 1 & 17 & 8 & 11 & 6 & 41 & 22 & 63 \\
\hline & Col umn Percent & 6.4 & 12.1 & 6.8 & 3.6 & 11.0 & 10.7 & 8.9 & 13.3 & 8.6 & 10.7 & 9.2 \\
\hline \multirow[t]{2}{*}{ Somewhat likely } & & 6 & 5 & 2 & 2 & 15 & 5 & 7 & 2 & 30 & 14 & 44 \\
\hline & Column Percent & 3.8 & 8.6 & 4.5 & 7.1 & 9.7 & 6.7 & 5.7 & 4.4 & 6.3 & 6.8 & 6.4 \\
\hline \multirow[t]{2}{*}{ Very likely } & & 26 & 14 & 13 & 9 & 67 & 48 & 35 & 10 & 141 & 81 & 222 \\
\hline & Column Percent & 16.6 & 24.1 & 29.5 & 32.1 & 43.5 & 64.0 & 28.5 & 22.2 & 29.5 & 39.3 & 32.5 \\
\hline \multicolumn{2}{|l|}{ Total } & 157 & 58 & 44 & 28 & 154 & 75 & 123 & 45 & 478 & 206 & 684 \\
\hline
\end{tabular}


Effects of Administrative License Revocation on Employment

Q38) CONSIDERING HOW YOU DRIVE WHEN Yreguency Tables by State, Offender Type and Total

\begin{tabular}{|c|c|c|c|c|c|c|c|c|c|c|c|c|}
\hline & & \multicolumn{8}{|c|}{ STATE } & \multirow{2}{*}{\multicolumn{2}{|c|}{ Total }} & \multirow[b]{4}{*}{ Total } \\
\hline & & \multirow{2}{*}{\multicolumn{2}{|c|}{$\begin{array}{l}\text { Pennsylvania } \\
\text { OFFENDER TYPE }\end{array}$}} & \multicolumn{2}{|c|}{ Maryl and } & \multicolumn{2}{|c|}{ Cal ifornia } & \multicolumn{2}{|c|}{ Del aware } & & & \\
\hline & & & & \multicolumn{2}{|c|}{ OFFENDER TYPE } & \multicolumn{2}{|c|}{ OFFENDER TYPE } & \multicolumn{2}{|c|}{ OFFENDER TYPE } & \multicolumn{2}{|c|}{ OFFENDER TYPE } & \\
\hline & & First & Multiple & First & Mult iple & First & Multiple & First & Mul tiple & First & Mul tiple & \\
\hline \multicolumn{2}{|l|}{ RESPONSE CATEGORY } & \multirow[b]{2}{*}{24} & \multirow[b]{2}{*}{18} & \multirow[b]{2}{*}{11} & \multirow[b]{2}{*}{4} & \multirow[b]{2}{*}{48} & \multirow[b]{2}{*}{29} & \multirow[b]{2}{*}{22} & \multirow[b]{2}{*}{8} & \multirow[b]{2}{*}{105} & \multirow[b]{2}{*}{59} & \multirow[b]{2}{*}{164} \\
\hline \multirow[t]{2}{*}{ Not at All Likely } & & & & & & & & & & & & \\
\hline & Column Percent & 57.1 & 78.3 & 73.3 & 57.1 & 53.3 & 50.9 & 44.0 & 47.1 & 53.3 & 56.7 & 54.5 \\
\hline \multirow[t]{2}{*}{$\overline{\text { Unl ikely }}$} & & 4 & 3 & 1 & 1 & 26 & 15 & 13 & 1 & 44 & 20 & 64 \\
\hline & Column Percent & 9.5 & 13.0 & 6.7 & 14.3 & 28.9 & 26.3 & 26.0 & 5.9 & 22.3 & 19.2 & 21.3 \\
\hline \multirow[t]{2}{*}{ Somewhat likely } & & 9 & 1 & 3 & $\cdots$ & 14 & 11 & 8 & 6 & 34 & 18 & 52 \\
\hline & Column Percent & 21.4 & 4.3 & 20.0 & -- & 15.6 & 19.3 & 16.0 & 35.3 & 17.3 & 17.3 & 17.3 \\
\hline \multirow[t]{2}{*}{ fery likely } & & 5 & 1 & $\cdots$ & 2 & 2 & 2 & 7 & 2 & 14 & 7 & 21 \\
\hline & Column Percent & 11.9 & 4.3 & -- & 28.6 & 2.2 & 3.5 & 14.0 & 11.8 & 7.1 & 6.7 & 7.0 \\
\hline \multicolumn{2}{|l|}{ otal } & 42 & 23 & 15 & 7 & 90 & 57 & 50 & 17 & 197 & 104 & 301 \\
\hline
\end{tabular}


Effects of Administrative License Revocation on Employment

Q39B) TO WHAT EXIENT Hrequency Tables by State Offender Tyese, and Total

\begin{tabular}{|c|c|c|c|c|c|c|c|c|c|c|c|c|}
\hline & & \multicolumn{8}{|c|}{ STATE } & \multirow{2}{*}{\multicolumn{2}{|c|}{ Total }} & \multirow[b]{4}{*}{ Total } \\
\hline & & \multicolumn{2}{|c|}{ Pennsylvania } & \multicolumn{2}{|c|}{ Maryland } & \multicolumn{2}{|c|}{ California } & \multicolumn{2}{|c|}{ Del aware } & & & \\
\hline & & \multicolumn{2}{|c|}{ OFFENDER TYPE } & \multicolumn{2}{|c|}{ OFFENDER TYPE } & \multicolumn{2}{|c|}{ OFFENDER TYPE } & \multicolumn{2}{|c|}{ OFFENDER TYPE } & \multicolumn{2}{|c|}{ OFFENDER TYPE } & \\
\hline & & First & Multiple & first & Mult iple & first & Mult iple & First & Mul tiple & First & Multiple & \\
\hline \multicolumn{2}{|l|}{ RESPONSE CATEGORY } & \multirow[b]{2}{*}{1} & \multirow[b]{2}{*}{--} & \multirow[b]{2}{*}{1} & \multirow[b]{2}{*}{--} & \multirow[b]{2}{*}{4} & \multirow[b]{2}{*}{1} & \multirow[b]{2}{*}{2} & \multirow[b]{2}{*}{--} & \multirow[b]{2}{*}{8} & \multirow[b]{2}{*}{1} & \multirow[b]{2}{*}{9} \\
\hline Not appl icable & & & & & & & & & & & & \\
\hline & Colum Percent & 0.9 & -- & 2.9 & -- & 2.7 & 1.4 & 1.9 & -- & 2.0 & 0.6 & 1.5 \\
\hline \multirow[t]{2}{*}{ Not at all } & & 16 & 5 & 5 & 4 & 19 & 9 & 9 & 8 & 49 & 26 & 75 \\
\hline & Column Percent & 13.7 & 10.9 & 14.7 & 22.2 & 12.9 & 12.5 & 8.3 & 18.2 & 12.1 & 14.4 & 12.8 \\
\hline \multirow[t]{2}{*}{ To a little exter } & & 8 & 2 & 2 & -- & 9 & 5 & 7 & 3 & 26 & 10 & 36 \\
\hline & Column Percent & 6.8 & 4.3 & 5.9 & -- & 6.1 & 6.9 & 6.5 & 6.8 & 6.4 & 5.6 & 6.1 \\
\hline \multirow[t]{2}{*}{ To some extent } & & 29 & 11 & 8 & 6 & 27 & 15 & 19 & 9 & 83 & 41 & 124 \\
\hline & Column Percent & 24.8 & 23.9 & 23.5 & 33.3 & 18.4 & 20.8 & 17.6 & 20.5 & 20.4 & 22.8 & 21.2 \\
\hline \multirow[t]{2}{*}{ To a great exten } & & 63 & 28 & 18 & 8 & 88 & 42 & 71 & 24 & 240 & 102 & 342 \\
\hline & Column Percent & 53.8 & 60.9 & 52.9 & 44.4 & 59.9 & 58.3 & 65.7 & 54.5 & 59.1 & 56.7 & 58.4 \\
\hline \multicolumn{2}{|l|}{ Total } & 117 & 46 & 34 & 18 & 147 & 72 & 108 & 44 & 406 & 180 & 586 \\
\hline
\end{tabular}


Effects of Administrative License Revocation on Employment Frequency Tables by State Offender Iype and Total
Q39C) TO WHAT EXTENT HAS YOUR LOSS OF LICENSE IHTERERED WITH SHOPPING?

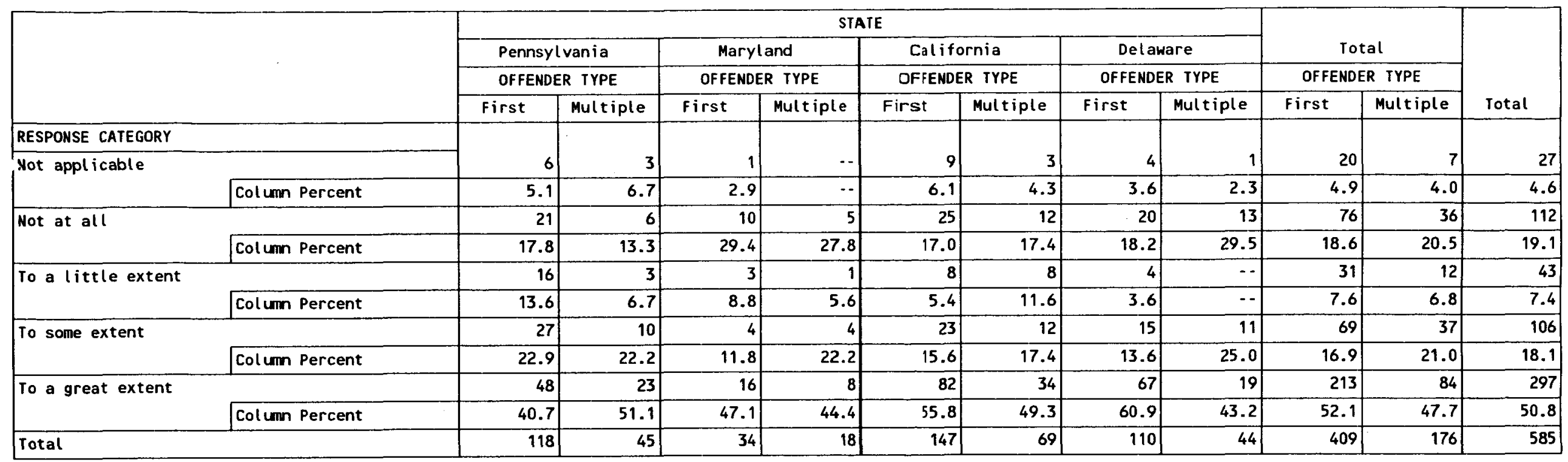


Effects of Administrative License Revocation on Employment

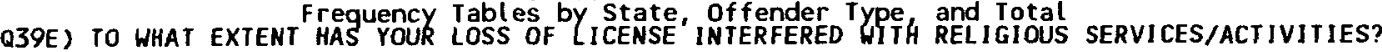

\begin{tabular}{|c|c|c|c|c|c|c|c|c|c|c|c|c|}
\hline & & \multicolumn{8}{|c|}{ STATE } & \multirow{2}{*}{\multicolumn{2}{|c|}{ Total }} & \multirow[b]{4}{*}{ Total } \\
\hline & & \multicolumn{2}{|c|}{ Pennsylvania } & \multicolumn{2}{|c|}{ Maryl and } & \multicolumn{2}{|c|}{ California } & \multicolumn{2}{|c|}{ Delaware } & & & \\
\hline & & \multicolumn{2}{|c|}{ OFFENDER TYPE } & \multicolumn{2}{|c|}{ OFFENDER TYPE } & \multicolumn{2}{|c|}{ OFFENDER TYPE } & \multicolumn{2}{|c|}{ OFFENDER TYPE } & \multicolumn{2}{|c|}{ OFFENDER TYPE } & \\
\hline & & First & Multiple & First & Multiple & First & Multiple & First & Multiple & First & Mult iple & \\
\hline \multicolumn{2}{|c|}{ ZESPONSE CATEGORY } & \multirow[b]{2}{*}{34} & \multirow[b]{2}{*}{13} & \multirow[b]{2}{*}{10} & \multirow[b]{2}{*}{6} & \multirow[b]{2}{*}{47} & \multirow[b]{2}{*}{23} & \multirow[b]{2}{*}{25} & \multirow[b]{2}{*}{9} & \multirow[b]{2}{*}{116} & \multirow[b]{2}{*}{51} & \multirow[b]{2}{*}{167} \\
\hline ot applicable & & & & & & & & & & & & \\
\hline & Column Percent & 29.1 & 28.9 & 30.3 & 33.3 & 33.1 & 34.8 & 23.1 & 20.5 & 29.0 & 29.5 & 29.1 \\
\hline \multirow[t]{2}{*}{ Oot at all } & & 33 & 11 & 10 & 3 & 38 & 13 & 28 & 14 & 109 & 41 & 150 \\
\hline & Column Percent & 28.2 & 24.4 & 30.3 & 16.7 & 26.8 & 19.7 & 25.9 & 31.8 & 27.3 & 23.7 & 26.2 \\
\hline \multirow[t]{2}{*}{.o a little exter } & & 11 & -- & $\cdots$ & 1 & 5 & 2 & 2 & 3 & 18 & 6 & 24 \\
\hline & Col umn Percent & 9.4 & $\cdots$ & $\cdots$ & 5.6 & 3.5 & 3.0 & 1.9 & 6.8 & 4.5 & 3.5 & 4.2 \\
\hline \multirow[t]{2}{*}{ - some extent } & & 17 & 7 & 4 & 1 & 17 & 5 & 15 & 5 & 53 & 18 & 71 \\
\hline & Column Percent & 14.5 & 15.6 & 12.1 & 5.6 & 12.0 & 7.6 & 13.9 & 11.4 & 13.3 & 10.4 & 12.4 \\
\hline \multirow[t]{2}{*}{ o a great exter } & & 22 & 14 & 9 & 7 & 35 & 23 & 38 & 13 & 104 & 57 & 161 \\
\hline & Col umn Percent & 18.8 & 31.1 & 27.3 & 38.9 & 24.6 & 34.8 & 35.2 & 29.5 & 26.0 & 32.9 & 28.1 \\
\hline \multicolumn{2}{|l|}{ iotal } & 117 & 45 & 33 & 18 & 142 & 66 & 108 & 44 & 400 & 173 & 573 \\
\hline
\end{tabular}


Effects of Administrative License Revocation on Employment

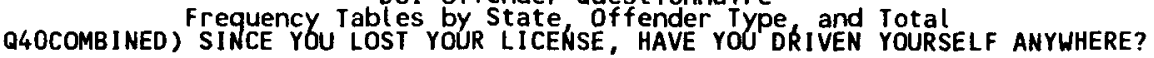

\begin{tabular}{|c|c|c|c|c|c|c|c|c|c|c|c|c|}
\hline & & \multicolumn{8}{|c|}{ STATE } & \multirow{2}{*}{\multicolumn{2}{|c|}{ Total }} & \multirow[b]{4}{*}{ Total } \\
\hline & & \multicolumn{2}{|c|}{ Pennsylvania } & \multicolumn{2}{|c|}{ Maryl and } & \multicolumn{2}{|c|}{ Cal ifornia } & \multicolumn{2}{|c|}{ Delaware } & & & \\
\hline & & \multicolumn{2}{|c|}{ OFFENDER TYPE } & \multicolumn{2}{|c|}{ OFFENDER TYPE } & \multicolumn{2}{|c|}{ OF FENDER TYPE } & \multicolumn{2}{|c|}{ OFFENDER TYPE } & \multicolumn{2}{|c|}{ OFFENDER TYPE } & \\
\hline & & First & Mult iple & first & Multiple & First & Multiple & First & Multiple & First & Multiple & \\
\hline \multicolumn{2}{|c|}{ RESPONSE } & \multirow[b]{2}{*}{51} & \multirow[b]{2}{*}{15} & \multirow[b]{2}{*}{21} & \multirow[b]{2}{*}{6} & \multirow[b]{2}{*}{101} & \multirow[b]{2}{*}{51} & \multirow[b]{2}{*}{39} & \multirow[b]{2}{*}{9} & \multirow[b]{2}{*}{212} & \multirow[b]{2}{*}{81} & \multirow[b]{2}{*}{293} \\
\hline Yes & & & & & & & & & & & & \\
\hline & Column Percent & 39.5 & 29.4 & 55.3 & 26.1 & 64.7 & 65.4 & 33.3 & 20.5 & 48.2 & 41.3 & 46.1 \\
\hline \multirow[t]{2}{*}{ No } & & 78 & 36 & 17 & 17 & 55 & 27 & 78 & 35 & 228 & 115 & 343 \\
\hline & Col umn Percent & 60.5 & 70.6 & 44.7 & 73.9 & 35.3 & 34.6 & 66.7 & 79.5 & 51.8 & 58.7 & 53.9 \\
\hline \multicolumn{2}{|c|}{ Total } & 129 & 51 & 38 & 23 & 156 & 78 & 117 & 44 & 440 & 196 & 636 \\
\hline
\end{tabular}




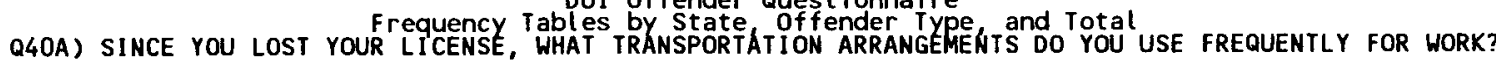

\begin{tabular}{|c|c|c|c|c|c|c|c|c|c|c|c|}
\hline & \multicolumn{8}{|c|}{ STATE } & \multirow{2}{*}{\multicolumn{2}{|c|}{ Total }} & \multirow[b]{4}{*}{ Total } \\
\hline & \multicolumn{2}{|c|}{ Pennsylvania } & \multicolumn{2}{|c|}{ Maryland } & \multicolumn{2}{|c|}{ California } & \multicolumn{2}{|c|}{ Delaware } & & & \\
\hline & \multicolumn{2}{|c|}{ OFFENDER TYPE } & \multicolumn{2}{|c|}{ OFFENDER TYPE } & \multicolumn{2}{|c|}{ OFFENDER TYPE } & \multicolumn{2}{|c|}{ OFFENDER TYPE } & \multicolumn{2}{|c|}{ OFFENDER TYPE } & \\
\hline & First & Multiple & First & Multiple & First & Multiple & First & Mul tiple & First & Multiple & \\
\hline \multicolumn{12}{|l|}{.ESPONSE } \\
\hline \multirow[t]{2}{*}{ ) Drive myself } & 17 & 8 & 8 & 4 & 57 & 33 & 28 & 7 & 110 & 52 & 162 \\
\hline & 11.9 & 12.9 & 21.1 & 18.2 & 29.2 & 33.3 & 20.6 & 14.0 & 21.5 & 22.3 & 21.7 \\
\hline Someone else drives me & 84 & 31 & 22 & 15 & 51 & 21 & 69 & 28 & 226 & 95 & 321 \\
\hline Column Percent & 58.7 & 50.0 & 57.9 & 68.2 & 26.2 & 21.2 & 50.7 & 56.0 & 44.1 & 40.8 & 43.1 \\
\hline ) Taxi or publ ic transportation & 12 & 9 & 2 & 1 & 48 & 23 & 16 & 3 & 78 & 36 & 114 \\
\hline Column Percent & 8.4 & 14.5 & 5.3 & 4.5 & 24.6 & 23.2 & 11.8 & 6.0 & 15.2 & 15.5 & 15.3 \\
\hline i) Halk or bicycle & 21 & 10 & 2 & 2 & 27 & 12 & 19 & 10 & 69 & 34 & 103 \\
\hline Column Percent & 14.7 & 16.1 & 5.3 & 9.1 & 13.8 & 12.1 & 14.0 & 20.0 & 13.5 & 14.6 & 13.8 \\
\hline ) other / not applicable & 9 & 4 & 4 & -- & 12 & 10 & 4 & 2 & 29 & 16 & 45 \\
\hline Column Percent & 6.3 & 6.5 & 10.5 & $\cdots$ & 6.2 & 10.1 & 2.9 & 4.0 & 5.7 & 6.9 & 6.0 \\
\hline otal & 143 & 62 & 38 & 22 & 195 & 99 & 136 & 50 & 512 & 233 & 745 \\
\hline
\end{tabular}


Q40B) SINCE YOU LOST YOUR LICENSE, WHAT Treguency Tables by State Of fender TYPe and Total a

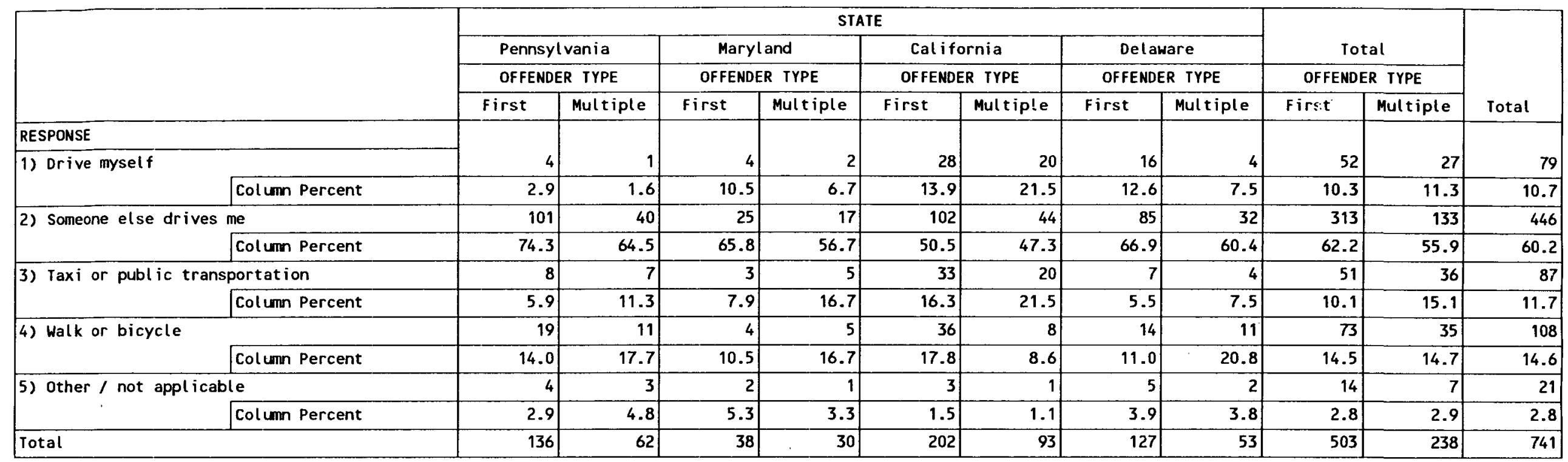


Q40C) SINCE YOU LOST YOUR IICGNSE, WHAT TRANSPORTATION ARRANGEMENTS DO YOU USE FREQUENTLY FOR SHOPPING?

\begin{tabular}{|c|c|c|c|c|c|c|c|c|c|c|c|}
\hline & \multicolumn{8}{|c|}{ STATE } & \multirow{2}{*}{\multicolumn{2}{|c|}{ Total }} & \multirow{4}{*}{ Total } \\
\hline & \multicolumn{2}{|c|}{ Pennsylvania } & \multicolumn{2}{|c|}{ Maryland } & \multicolumn{2}{|c|}{ Cal ifornia } & \multicolumn{2}{|c|}{ Delaware } & & & \\
\hline & \multicolumn{2}{|c|}{ OFFENDER TYPE } & \multicolumn{2}{|c|}{ OFFENDER TYPE } & \multicolumn{2}{|c|}{ OFFENDER TYPE } & \multicolumn{2}{|c|}{ OFFENDER TYPE } & \multicolumn{2}{|c|}{ OFFENDER TYPE } & \\
\hline & First & Multiple & First & Mult iple & First & Mult iple & First & Mult iple & first & Multiple & \\
\hline \multicolumn{12}{|l|}{ RESPONSE } \\
\hline 1) Drive myself & 8 & 5 & 4 & 3 & 37 & 27 & 25 & 4 & 74 & 39 & 113 \\
\hline Column Percent & 6.3 & 9.1 & 11.4 & 13.6 & 21.0 & 35.1 & 19.8 & 7.7 & 15.9 & 18.9 & 16.8 \\
\hline 2) Someone else drives me & 86 & 35 & 24 & 11 & 74 & 28 & 80 & 32 & 264 & 106 & 370 \\
\hline Column Percent & 67.2 & 63.6 & 68.6 & 50.0 & 42.0 & 36.4 & 63.5 & 61.5 & 56.8 & 51.5 & 55.1 \\
\hline 3) Taxi or public transportation & 9 & 5 & -- & 4 & 23 & 13 & 4 & 5 & 36 & 27 & 63 \\
\hline Column Percent & 7.0 & 9.1 & -- & 18.2 & 13.1 & 16.9 & 3.2 & 9.6 & 7.7 & 13.1 & 9.4 \\
\hline 4) Walk or bicycle & 19 & 8 & 3 & 3 & 37 & 7 & 13 & 9 & 72 & 27 & 99 \\
\hline Column Percent & 14.8 & 14.5 & 8.6 & 13.6 & 21.0 & 9.1 & 10.3 & 17.3 & 15.5 & 13.1 & 14.8 \\
\hline 5) Other / not applicable & 6 & 2 & 4 & 1 & 5 & 2 & 4 & 2 & 19 & 7 & 26 \\
\hline Column Percent & 4.7 & 3.6 & 11.4 & 4.5 & 2.8 & 2.6 & 3.2 & 3.8 & 4.1 & 3.4 & 3.9 \\
\hline Total & 128 & 55 & 35 & 22 & 176 & 77 & 126 & 52 & 465 & 206 & 671 \\
\hline
\end{tabular}


Effects of Administrative License Revocation on Employment

Freguency Tables by State off fender Type and Total
Q40D) SINCE YOU LOST YOUR LICENSE, WHAT FRANSPORTATION ARRANGEMENTS DO YoU USE FREQUENILY FOR MEDICAL APPOINTMENTS?

\begin{tabular}{|c|c|c|c|c|c|c|c|c|c|c|c|c|}
\hline & & \multicolumn{8}{|c|}{ STATE } & \multirow{2}{*}{\multicolumn{2}{|c|}{ Total }} & \multirow[b]{4}{*}{ Total } \\
\hline & & \multicolumn{2}{|c|}{ Pennsylvania } & \multicolumn{2}{|c|}{ Maryland } & \multicolumn{2}{|c|}{ California } & \multicolumn{2}{|c|}{ Delaware } & & & \\
\hline & & \multicolumn{2}{|c|}{ OFFENDER TYPE } & \multicolumn{2}{|c|}{ OFFENDER TYPE } & \multicolumn{2}{|c|}{ OFFENDER TYPE } & \multicolumn{2}{|c|}{ OFFENDER TYPE } & \multicolumn{2}{|c|}{ OFFENDER TYPE } & \\
\hline & & First & Mul tiple & First & Multiple & First & Multiple & First & Multiple & First & Mult iple & \\
\hline \multicolumn{2}{|l|}{ RESPONSE } & \multirow[b]{2}{*}{9} & \multirow[b]{2}{*}{7} & \multirow[b]{2}{*}{6} & \multirow[b]{2}{*}{4} & \multirow[b]{2}{*}{44} & \multirow[b]{2}{*}{30} & \multirow[b]{2}{*}{22} & \multirow[b]{2}{*}{6} & \multirow[b]{2}{*}{81} & \multirow[b]{2}{*}{47} & \multirow[b]{2}{*}{128} \\
\hline 1) Drive myself & & & & & & & & & & & & \\
\hline & Column Percent & 7.0 & 12.5 & 16.2 & 15.4 & 25.9 & 35.7 & 18.8 & 11.8 & 17.9 & 21.7 & 19.1 \\
\hline \multicolumn{2}{|l|}{ 2) Someone else drives me } & 82 & 37 & 22 & 11 & 67 & 31 & 70 & 29 & 241 & 108 & 349 \\
\hline & Col umn Percent & 64.1 & 66.1 & 59.5 & 42.3 & 39.4 & 36.9 & 59.8 & 56.9 & 53.3 & 49.8 & 52.2 \\
\hline \multicolumn{2}{|c|}{ 3) Taxi or public transportation } & 7 & 6 & 2 & 4 & 23 & 16 & $6)$ & 6 & 38 & 32 & 70 \\
\hline & Column Percent & 5.5 & 10.7 & 5.4 & 15.4 & 13.5 & 19.0 & 5.1 & 11.8 & 8.4 & 14.7 & 10.5 \\
\hline \multirow[t]{2}{*}{ 4) Walk or bicycle } & & 5 & 5 & 1 & 3 & 17 & 3 & 6 & 8 & 29 & 19 & 48 \\
\hline & Colum Percent & 3.9 & 8.9 & 2.7 & 11.5 & 10.0 & 3.6 & 5.1 & 15.7 & 6.4 & 8.8 & 7.2 \\
\hline \multicolumn{2}{|l|}{ 5) Other / not appl icable } & 25 & 1 & 6 & 4 & 19 & 4 & 13 & 2 & 63 & 11 & 74 \\
\hline & Column Percent & 19.5 & 1.8 & 16.2 & 15.4 & 11.2 & 4.8 & 11.1 & 3.9 & 13.9 & 5.1 & 11.1 \\
\hline \multicolumn{2}{|l|}{ Total } & 128 & 56 & 37 & 26 & 170 & 84 & 117 & 51 & 452 & 217 & 669 \\
\hline
\end{tabular}

NOIE: This question was not asked of DUI offenders who had not lost their license.
NOTE: Respondents could provide more than one answer for this question (circle all that apply). 
Frequency Tables by State offender Yype and Total
WHAT TRANSPORTATION ARRANGEMENTS DO YOU USE FREQUENILY FOR RELIGIOUS SERVICES/ACTIVITIES?

\begin{tabular}{|c|c|c|c|c|c|c|c|c|c|c|c|c|}
\hline & & \multicolumn{8}{|c|}{ STATE } & \multirow{2}{*}{\multicolumn{2}{|c|}{ Total }} & \multirow[b]{4}{*}{ Total } \\
\hline & & \multicolumn{2}{|c|}{ Pennsylvania } & \multicolumn{2}{|c|}{ Maryl and } & \multicolumn{2}{|c|}{ California } & \multicolumn{2}{|c|}{ Delaware } & & & \\
\hline & & \multicolumn{2}{|c|}{ OFFENDER TYPE } & \multicolumn{2}{|c|}{ OFFENDER TYPE } & \multicolumn{2}{|c|}{ OF FENDER TYPE } & \multicolumn{2}{|c|}{ OFFENDER TYPE } & \multicolumn{2}{|c|}{ OFFENDER TYPE } & \\
\hline & & First & Multiple & First & Multiple & First & Multiple & First & Multiple & First & Multiple & \\
\hline \multicolumn{2}{|l|}{.ESPONSE } & \multirow[b]{2}{*}{5} & \multirow[b]{2}{*}{1} & \multirow[b]{2}{*}{4} & \multirow[b]{2}{*}{1} & \multirow[b]{2}{*}{24} & \multirow[b]{2}{*}{16} & \multirow[b]{2}{*}{15} & \multirow[b]{2}{*}{4} & \multirow[b]{2}{*}{48} & \multirow[b]{2}{*}{22} & \multirow[b]{2}{*}{70} \\
\hline ) Drive myself & & & & & & & & & & & & \\
\hline & Column Percent & 4.0 & 2.0 & 11.4 & 3.8 & 16.4 & 21.1 & 14.0 & 8.7 & 11.6 & 11.1 & 11.5 \\
\hline \multicolumn{2}{|l|}{ S Someone else drives me } & 61 & 30 & 17 & 10 & 44 & 23 & 57 & 23 & 179 & 86 & 265 \\
\hline & Column Percent & 48.8 & 60.0 & 48.6 & 38.5 & 30.1 & 30.3 & 53.3 & 50.0 & 43.3 & 43.4 & 43.4 \\
\hline \multicolumn{2}{|c|}{ 3) Taxi or public transportation } & 5 & 3 & 3 & 3 & 11 & 10 & 2 & 4 & 21 & 20 & 41 \\
\hline & Col umn Percent & 4.0 & 6.0 & 8.6 & 11.5 & 7.5 & 13.2 & 1.9 & 8.7 & 5.1 & 10.1 & 6.7 \\
\hline \multirow[t]{2}{*}{ ) Halk or bicycle } & & 13 & 4 & 2 & 3 & 12 & 2 & 7 & 5 & 34 & 14 & 48 \\
\hline & Column Percent & 10.4 & 8.0 & 5.7 & 11.5 & 8.2 & 2.6 & 6.5 & 10.9 & 8.2 & 7.1 & 7.9 \\
\hline \multicolumn{2}{|l|}{ i) other / not applicable } & 41 & 12 & 9 & 9 & 55 & 25 & 26 & 10 & 131 & 56 & 187 \\
\hline & Column Percent & 32.8 & 24.0 & 25.7 & 34.6 & 37.7 & 32.9 & 24.3 & 21.7 & 31.7 & 28.3 & 30.6 \\
\hline \multicolumn{2}{|l|}{ otal } & 125 & 50 & 35 & 26 & 146 & 76 & 107 & 46 & 413 & 198 & 611 \\
\hline
\end{tabular}


Effects of Administrative License Revocation on Employment

Freguency Tables by state Of fender Type and Total
Q40G) HOW DID YOU GET IO WORK ON THE LAST DAY YOU WORKED?

\begin{tabular}{|c|c|c|c|c|c|c|c|c|c|c|c|}
\hline & \multicolumn{8}{|c|}{ STATE } & \multirow{2}{*}{\multicolumn{2}{|c|}{ Total }} & \multirow[b]{4}{*}{ Total } \\
\hline & \multirow{2}{*}{\multicolumn{2}{|c|}{$\begin{array}{l}\text { Pennsylvania } \\
\text { OFFENDER TYPE }\end{array}$}} & \multirow{2}{*}{\multicolumn{2}{|c|}{$\frac{\text { Maryland }}{\text { OFFENDER TYPE }}$}} & \multirow{2}{*}{\multicolumn{2}{|c|}{$\begin{array}{l}\text { Cali ifornia } \\
\text { OFFENDER TYPE }\end{array}$}} & \multicolumn{2}{|c|}{ Delaware } & & & \\
\hline & & & & & & & OFFENDE & R TYPE & OFFENDE & R TYPE & \\
\hline & First & Multiple & First & Multiple & First & Multiple & First & Mult iple & First & Multiple & \\
\hline \multicolumn{12}{|l|}{ RESPONSE } \\
\hline \multirow[t]{2}{*}{.) Drive myself } & 41 & 12 & 19 & 5 & 71 & 41 & 31 & 8 & 162 & 66 & 228 \\
\hline & 34.5 & 24.0 & 55.9 & 26.3 & 46.1 & 58.6 & 28.2 & 18.2 & 38.8 & 36.1 & 38.0 \\
\hline \multirow[t]{2}{*}{ D) Someone else drives } & 55 & 25 & 12 & 10 & 37 & 10 & 58 & 25 & 162 & 70 & 232 \\
\hline & 46.2 & 50.0 & 35.3 & 52.6 & 24.0 & 14.3 & 52.7 & 56.8 & 38.8 & 38.3 & 38.7 \\
\hline 3) Taxi or public transportation & 3 & 3 & 1 & 1 & 22 & 11 & 10 & 1 & 36 & 16 & 52 \\
\hline Column Percent & 2.5 & 6.0 & 2.9 & 5.3 & 14.3 & 15.7 & 9.1 & 2.3 & 8.6 & 8.7 & 8.7 \\
\hline \multirow[t]{2}{*}{ 4) Walk or bicycle } & 13 & 7 & -- & 2 & 17 & 3 & 8 & 8 & 38 & 20 & 58 \\
\hline & 10.9 & 14.0 & -- & 10.5 & 11.0 & 4.3 & 7.3 & 18.2 & 9.1 & 10.9 & 9.7 \\
\hline 5) Other / not applicable & 7 & 3 & 2 & 1 & 7 & 5 & 3 & 2 & 19 & 11 & 30 \\
\hline Column Percent & 5.9 & 6.0 & 5.9 & 5.3 & 4.5 & 7.1 & 2.7 & 4.5 & 4.6 & 6.0 & 5.0 \\
\hline Total & 119 & 50 & 34 & 19 & 154 & 70 & 110 & 44 & 417 & 183 & 600 \\
\hline
\end{tabular}


Effects of Administrative License Revocation on Employment

Q43) IN WHICH OF THE FOLLOWING ETHNIt GROUPS WOULb fou CLASSIFY YOURSELF?

\begin{tabular}{|c|c|c|c|c|c|c|c|c|c|c|c|c|}
\hline & & \multicolumn{8}{|c|}{ STATE } & \multirow{2}{*}{\multicolumn{2}{|c|}{ Total }} & \multirow[b]{4}{*}{ Total } \\
\hline & & \multicolumn{2}{|c|}{ Pennsylvania } & \multicolumn{2}{|c|}{ Maryland } & \multicolumn{2}{|c|}{ California } & \multicolumn{2}{|c|}{ Delaware } & & & \\
\hline & & \multicolumn{2}{|c|}{ OFFENDER TYPE } & \multicolumn{2}{|c|}{ OFFENDER TYPE } & \multicolumn{2}{|c|}{ OFFENDER TYPE } & \multicolumn{2}{|c|}{ OFFENDER TYPE } & \multicolumn{2}{|c|}{ OFFENDER TYPE } & \\
\hline & & First & Multiple & First & Multiple & First & Mul tiple & First & Multiple & First & Multiple & \\
\hline \multicolumn{2}{|l|}{ RESPONSE CATEGORY } & \multirow[b]{2}{*}{151} & \multirow[b]{2}{*}{55} & \multirow[b]{2}{*}{83} & \multirow[b]{2}{*}{28} & \multirow[b]{2}{*}{152} & \multirow[b]{2}{*}{70} & \multirow[b]{2}{*}{124} & \multirow[b]{2}{*}{41} & \multirow[b]{2}{*}{510} & \multirow[b]{2}{*}{194} & \multirow[b]{2}{*}{704} \\
\hline White, not of Hispanic on & rign & & & & & & & & & & & \\
\hline & Col umn Percent & 93.2 & 90.2 & 87.4 & 77.8 & 91.6 & 89.7 & 87.9 & 87.2 & 90.4 & 87.4 & 89.6 \\
\hline \multirow[t]{2}{*}{ other } & & 11 & 6 & 12 & 8 & 14 & 8 & 17 & 6 & 54 & 28 & 82 \\
\hline & Column Percent & 6.8 & 9.8 & 12.6 & 22.2 & 8.4 & 10.3 & 12.1 & 12.8 & 9.6 & 12.6 & 10.4 \\
\hline \multicolumn{2}{|l|}{ Total } & 162 & 61 & 95 & 36 & 166 & 78 & 141 & 47 & 564 & 222 & 786 \\
\hline
\end{tabular}


Effects of Administrative License Revocation on Employment

Frequency Tables by State Offender Type and Total
Q45) HHAT IS YOUR HIGHEST LEVEL Of EDUCATION?

\begin{tabular}{|c|c|c|c|c|c|c|c|c|c|c|c|}
\hline & \multicolumn{8}{|c|}{ STATE } & \multirow{2}{*}{\multicolumn{2}{|c|}{ Total }} & \multirow[b]{4}{*}{ Total } \\
\hline & \multicolumn{2}{|c|}{ Pennsylvania } & \multicolumn{2}{|c|}{ Maryl and } & \multicolumn{2}{|c|}{ Cal ifornia } & \multicolumn{2}{|c|}{ Delaware } & & & \\
\hline & \multicolumn{2}{|c|}{ OFFENDER TYPE } & \multicolumn{2}{|c|}{ OFFENDER TYPE } & \multicolumn{2}{|c|}{ OF FENDER TYPE } & \multicolumn{2}{|c|}{ OFFENDER TYPE } & \multicolumn{2}{|c|}{ OFFENDER TYPE } & \\
\hline & First & Multiple & First & Multiple & First & Multiple & First & Multiple & First & Multiple & \\
\hline RESPONSE & \multirow[b]{2}{*}{4} & \multirow[b]{2}{*}{--} & \multirow[b]{2}{*}{3} & \multirow[b]{2}{*}{1} & \multirow[b]{2}{*}{$\cdots$} & \multirow[b]{2}{*}{--} & \multirow[b]{2}{*}{ 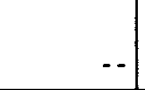 } & \multirow[b]{2}{*}{--} & \multirow[b]{2}{*}{7} & \multirow[b]{2}{*}{1} & \multirow[b]{2}{*}{8} \\
\hline 1) Junior high school (or less) & & & & & & & & & & & \\
\hline Col umn Percent & 2.4 & $\cdots$ & 3.2 & 2.7 & -- & $\cdots$ & -- & -- & 1.2 & 0.4 & 1.0 \\
\hline 2) Some high school & 10 & 4 & 6 & 2 & 2 & 3 & 10 & 8 & 28 & 17 & 45 \\
\hline Column Percent & 6.1 & 6.3 & 6.3 & 5.4 & 1.2 & 3.8 & 7.0 & 17.0 & 4.9 & 7.5 & 5.7 \\
\hline 3) High school graduate & 44 & 25 & 32 & 14 & 27 & 12 & 42 & 16 & 145 & 67 & 212 \\
\hline Column Percent & 26.8 & 39.1 & 33.7 & 37.8 & 16.2 & 15.2 & 29.6 & 34.0 & 25.5 & 29.5 & 26.7 \\
\hline 4) Trade school certificate & 8 & 10 & 3 & 3 & 4 & 6 & 16 & 8 & 31 & 27 & 58 \\
\hline Column Percent & 4.9 & 15.6 & 3.2 & 8.1 & 2.4 & 7.6 & 11.3 & 17.0 & 5.5 & 11.9 & 7.3 \\
\hline 5) Some college, but no degree & 45 & 14 & 14 & 10 & 53 & 29 & 38 & 8 & 150 & 61 & 211 \\
\hline Column Percent & 27.4 & 21.9 & 14.7 & 27.0 & 31.7 & 36.7 & 26.8 & 17.0 & 26.4 & 26.9 & 26.5 \\
\hline 6) Associates or 2-year college degree & 10 & $\cdots$ & 9 & 3 & 19 & 4 & 9 & -- & 47 & 7 & 54 \\
\hline Col umn Percent & 6.1 & $\cdots$ & 9.5 & 8.1 & 11.4 & 5.1 & 6.3 & -- & 8.3 & 3.1 & 6.8 \\
\hline 7) Bachelors or 4-year college degree & 30 & 9 & 22 & 2 & 39 & 18 & 21 & 7 & 112 & 36 & 148 \\
\hline Column Percent & 18.3 & 14.1 & 23.2 & 5.4 & 23.4 & 22.8 & 14.8 & 14.9 & 19.7 & 15.9 & 18.6 \\
\hline 8) Masters or doctorate degree & 13 & 2 & 6 & 2 & 23 & 7 & 6 & $\cdots$ & 48 & 11 & 59 \\
\hline Column Percent & 7.9 & 3.1 & 6.3 & 5.4 & 13.8 & 8.9 & 4.2 & -- & 8.5 & 4.8 & 7.4 \\
\hline Total & 164 & 64 & 95 & 37 & 167 & 79 & 142 & 47 & 568 & 227 & 795 \\
\hline
\end{tabular}


Frequency Tables by State, offender Iype, and Total

\begin{tabular}{|c|c|c|c|c|c|c|c|c|c|c|c|c|}
\hline & & \multicolumn{8}{|c|}{ STATE } & \multirow{2}{*}{\multicolumn{2}{|c|}{ Total }} & \multirow[b]{4}{*}{ Total } \\
\hline & & \multicolumn{2}{|c|}{ Pennsylvania } & \multicolumn{2}{|c|}{ Maryland } & \multicolumn{2}{|c|}{ California } & \multicolumn{2}{|c|}{ Del aware } & & & \\
\hline & & \multicolumn{2}{|c|}{ OFFENDER TYPE } & \multicolumn{2}{|c|}{ OFFENDER TYPE } & \multicolumn{2}{|c|}{ OF FENDER TYPE } & \multicolumn{2}{|c|}{ OFFENDER TYPE } & \multicolumn{2}{|c|}{ OFFENDER TYPE } & \\
\hline & & First & Multiple & First & Multiple & First & Multiple & First & Mult tiple & First & Multiple & \\
\hline \multicolumn{13}{|c|}{ RESPONSE } \\
\hline \multirow[t]{2}{*}{ Male } & & 124 & 58 & 82 & 32 & 118 & 64 & 121 & 42 & 445 & 196 & 641 \\
\hline & Column Percent & 76.1 & 90.6 & 86.3 & 86.5 & 70.7 & 81.0 & 85.2 & 89.4 & 78.5 & 86.3 & 80.7 \\
\hline \multirow[t]{2}{*}{ Female } & & 39 & 6 & 13 & 5 & 49 & 15 & 21 & 5 & 122 & 31 & 153 \\
\hline & Column Percent & 23.9 & 9.4 & 13.7 & 13.5 & 29.3 & 19.0 & 14.8 & 10.6 & 21.5 & 13.7 & 19.3 \\
\hline \multicolumn{2}{|l|}{ Total } & 163 & 64 & 95 & 37 & 167 & 79 & 142 & 47 & 567 & 227 & 794 \\
\hline
\end{tabular}


Effects of Administrative License Revocation on Empl oyment

Frequency Tables by State of of ender Iype and Total
047) WHAT IS YOUR CURRENT MARITAL StaTUS?

\begin{tabular}{|c|c|c|c|c|c|c|c|c|c|c|c|c|}
\hline & & \multicolumn{8}{|c|}{ STATE } & \multirow{2}{*}{\multicolumn{2}{|c|}{ Total }} & \multirow[b]{4}{*}{ Total } \\
\hline & & \multicolumn{2}{|c|}{ Pennsylvania } & \multicolumn{2}{|c|}{ Maryl and } & \multicolumn{2}{|c|}{ Cal ifornia } & \multicolumn{2}{|c|}{ Delaware } & & & \\
\hline & & \multicolumn{2}{|c|}{ OFFENDER TYPE } & \multicolumn{2}{|c|}{ OFFENDER TYPE } & \multicolumn{2}{|c|}{ OFFENDER TYPE } & \multicolumn{2}{|c|}{ OFFENDER TYPE } & \multicolumn{2}{|c|}{ OFFENDER TYPE } & \\
\hline & & First & Multiple & First & Mult iple & First & Multiple & First & Multiple & First & Multiple & \\
\hline \multicolumn{13}{|c|}{ RESPONSE CATEGORY } \\
\hline \multirow[t]{2}{*}{ Single } & & 89 & 24 & 43 & 20 & 86 & 47 & 80 & 20 & 298 & 111 & 409 \\
\hline & Column Percent & 54.3 & 37.5 & 45.3 & 54.1 & 51.2 & 59.5 & 56.3 & 42.6 & 52.4 & 48.9 & 51.4 \\
\hline \multirow[t]{2}{*}{ Tarried } & & 54 & 23 & 22 & 6 & 41 & 10 & 39 & 17 & 156 & 56 & 212 \\
\hline & Column Percent & 32.9 & 35.9 & 23.2 & 16.2 & 24.4 & 12.7 & 27.5 & 36.2 & 27.4 & 24.7 & 26.6 \\
\hline \multicolumn{2}{|c|}{ Dreviously Married } & 21 & 17 & 30 & 11 & 41 & 22 & 23 & 10 & 115 & 60 & 175 \\
\hline & Column Percent & 12.8 & 26.6 & 31.6 & 29.7 & 24.4 & 27.8 & 16.2 & 21.3 & 20.2 & 26.4 & 22.0 \\
\hline \multicolumn{2}{|l|}{ Total } & 164 & 64 & 95 & 37 & 168 & 79 & 142 & 47 & 569 & 227 & 796 \\
\hline
\end{tabular}


Effects of Adninistrative License Revocation on Employment

Q48) OTHER THAN YOURSELF, HOW MANY PEOPLE LIVE IN YOUR' HOUSEHOLD WHO CURRENTLY HAVE A VALID DRIVER'S LICENSE?

\begin{tabular}{|c|c|c|c|c|c|c|c|c|c|c|c|c|c|}
\hline & & & \multicolumn{8}{|c|}{ STATE } & \multirow{2}{*}{\multicolumn{2}{|c|}{ Total }} & \multirow[b]{4}{*}{ Total } \\
\hline & & & \multicolumn{2}{|c|}{ Pennsylvania } & \multicolumn{2}{|c|}{ Maryland } & \multicolumn{2}{|c|}{ Cal ifornia } & \multicolumn{2}{|c|}{ Delaware } & & & \\
\hline & & & \multicolumn{2}{|c|}{ OFFENDER TYPE } & \multicolumn{2}{|c|}{ OFFENDER TYPE } & \multicolumn{2}{|c|}{ OFFENDER TYPE } & \multicolumn{2}{|c|}{ OFFENDER TYPE } & \multicolumn{2}{|c|}{ OFFENDER IYPE } & \\
\hline & & & First & Multiple & First & Multiple & First & Mult tiple & First & Multiple & First & Multiple & \\
\hline \multicolumn{3}{|c|}{ RESPONSE CATEGORY } & \multirow[b]{2}{*}{36} & \multirow[b]{2}{*}{12} & \multirow[b]{2}{*}{24} & \multirow[b]{2}{*}{8} & \multirow[b]{2}{*}{49} & \multirow[b]{2}{*}{30} & \multirow[b]{2}{*}{39} & \multirow[b]{2}{*}{8} & \multirow[b]{2}{*}{148} & \multirow[b]{2}{*}{58} & \multirow[b]{2}{*}{206} \\
\hline None & & & & & & & & & & & & & \\
\hline & Column Percent & & 22.4 & 18.8 & 26.1 & 22.2 & 29.5 & 38.5 & 27.9 & 17.0 & 26.5 & 25.8 & 26.3 \\
\hline \multirow[t]{2}{*}{ One } & & & 69 & 32 & 43 & 12 & 78 & 34 & 51 & 23 & 241 & 101 & 342 \\
\hline & Column Percent & $\cdot$ & 42.9 & 50.0 & 46.7 & 33.3 & 47.0 & 43.6 & 36.4 & 48.9 & 43.1 & 44.9 & 43.6 \\
\hline \multirow[t]{2}{*}{ Two or more } & & & 56 & 20 & 25 & 16 & 39 & 14 & 50 & 16 & 170 & 66 & 236 \\
\hline & Column Percent & & 34.8 & 31.3 & 27.2 & 44.4 & 23.5 & 17.9 & 35.7 & 34.0 & 30.4 & 29.3 & 30.1 \\
\hline \multicolumn{3}{|l|}{ Total } & 161 & 64 & 92 & 36 & 166 & 78 & 140 & 47 & 559 & 225 & 784 \\
\hline
\end{tabular}




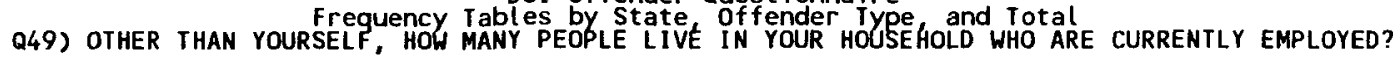

\begin{tabular}{|c|c|c|c|c|c|c|c|c|c|c|c|c|}
\hline & & \multicolumn{8}{|c|}{ STATE } & \multirow{2}{*}{\multicolumn{2}{|c|}{ Total }} & \multirow[b]{4}{*}{ Total } \\
\hline & & \multicolumn{2}{|c|}{ Pennsylvania } & \multicolumn{2}{|c|}{ Maryland } & \multicolumn{2}{|c|}{ Cal ifornia } & \multicolumn{2}{|c|}{ Delaware } & & & \\
\hline & & \multicolumn{2}{|c|}{ OFFENDER TYPE } & \multicolumn{2}{|c|}{ OFFENDER TYPE } & \multicolumn{2}{|c|}{ OFFENDER TYPE } & \multicolumn{2}{|c|}{ OFFENDER TYPE } & \multicolumn{2}{|c|}{ OFFENDER TYPE } & \\
\hline & & First & Multiple & First & Mult iple & first & Multiple & First & Multiple & First & Multiple & \\
\hline \multicolumn{13}{|c|}{ RESPONSE CATEGORY } \\
\hline \multirow[t]{2}{*}{ Jone } & & 46 & 19 & 30 & 12 & 55 & 31 & 50 & 10 & 181 & 72 & 253 \\
\hline & Column Percent & 28.9 & 30.2 & 32.6 & 34.3 & 33.3 & 40.3 & 36.0 & 21.3 & 32.6 & 32.4 & 32.6 \\
\hline \multirow[t]{2}{*}{ ne } & & 58 & 28 & 37 & 8 & 73 & 32 & 43 & 23 & 211 & 91 & 302 \\
\hline & Column Percent & 36.5 & 44.4 & 40.2 & 22.9 & 44.2 & 41.6 & 30.9 & 48.9 & 38.0 & 41.0 & 38.9 \\
\hline \multicolumn{2}{|c|}{ wo or more } & 55 & 16 & 25 & 15 & 37 & 14 & 46 & 14 & 163 & 59 & 222 \\
\hline & Colum Percent & 34.6 & 25.4 & 27.2 & 42.9 & 22.4 & 18.2 & 33.1 & 29.8 & 29.4 & 26.6 & 28.6 \\
\hline \multicolumn{2}{|l|}{. otal } & 159 & 63 & 92 & 35 & 165 & 77 & 139 & 47 & 555 & 222 & 777 \\
\hline
\end{tabular}


Effects of Administrative License Revocation on Employment Tabulation by State of fender Iype and Total

Average Value and Frequency Count for Cont inuous Variables

\begin{tabular}{|c|c|c|c|c|c|c|c|c|c|c|c|c|}
\hline & & \multicolumn{8}{|c|}{ STATE } & \multirow{2}{*}{\multicolumn{2}{|c|}{ Total }} & \multirow[b]{4}{*}{ Total } \\
\hline & & \multicolumn{2}{|c|}{ Pennsylvania } & \multicolumn{2}{|c|}{ Maryland } & \multicolumn{2}{|c|}{ California } & \multicolumn{2}{|c|}{ Delaware } & & & \\
\hline & & \multicolumn{2}{|c|}{ OF FENDER TYPE } & \multicolumn{2}{|c|}{ OFFENDER TYPE } & \multicolumn{2}{|c|}{ OFFENDER TYPE } & \multicolumn{2}{|c|}{ OFFENDER TYPE } & \multicolumn{2}{|c|}{ OFFENDER TYPE } & \\
\hline & & First & Multiple & First & Multiple & First & Multiple & First & Multiple & First & Multiple & \\
\hline \multirow{2}{*}{$\begin{array}{l}\text { Months from DUI } \\
\text { arrest to interview }\end{array}$} & Average Value & 8.39 & 14.57 & 7.98 & 7.24 & 4.96 & 9.53 & 8.75 & 15.06 & 7.40 & 11.68 & 8.63 \\
\hline & Frequency Count & 168 & 65 & 96 & 38 & 171 & 83 & 144 & 47 & 579 & 233 & 812 \\
\hline \multirow{2}{*}{$\begin{array}{l}\text { Q9) Number of months } \\
\text { answrd in cal endar }\end{array}$} & Average Value & 29.76 & 30.85 & 30.19 & 30.11 & 31.43 & 30.76 & 30.65 & 31.36 & 30.54 & 30.80 & 30.62 \\
\hline & Frequency Count & 168 & 65 & 96 & 38 & 171 & 83 & 144 & 47 & 579 & 233 & 812 \\
\hline \multirow{2}{*}{$\begin{array}{l}\text { 09) Number of months } \\
\text { wi th ento oyment }\end{array}$} & Average Value & 28.32 & 29.89 & 28.92 & 29.32 & 29.92 & 26.71 & 29.38 & 30.68 & 29.16 & 28.82 & 29.06 \\
\hline & Frequency Count & 168 & 65 & 96 & 38 & 171 & 83 & 144 & 47 & 579 & 233 & 812 \\
\hline \multirow{2}{*}{$\begin{array}{l}\text { Q9) Number of months } \\
\text { at tending school }\end{array}$} & Average Value & 7.51 & 1.85 & 5.69 & 4.00 & 3.89 & 4.81 & 7.46 & 2.66 & 6.13 & 3.42 & 5.35 \\
\hline & Frequency Count & 168 & 65 & 96 & 38 & 171 & 83 & 144 & 47 & 579 & 233 & 812 \\
\hline \multirow{2}{*}{$\begin{array}{l}\text { Q9) Months } \\
\text { unemply/search ing } \\
\text { for work }\end{array}$} & Average Value & 5.17 & 8.58 & 5.65 & 6.32 & 6.81 & 7.41 & 4.27 & 9.96 & 5.51 & 8.07 & 6.25 \\
\hline & Frequency Count & 168 & 65 & 96 & 38 & 171 & 83 & 144 & 47 & 579 & 233 & 812 \\
\hline \multirow{2}{*}{$\begin{array}{l}\text { 09) Months } \\
\text { unempl } y / \text { not } \\
\text { searchng for work }\end{array}$} & Average Value & 2.85 & 2.38 & 1.25 & 0.00 & 3.89 & 2.96 & 1.92 & 2.64 & 2.66 & 2.25 & 2.54 \\
\hline & Frequency Count & 168 & 65 & 96 & 38 & 171 & 83 & 144 & 47 & 579 & 233 & 812 \\
\hline \multirow{2}{*}{$\begin{array}{l}\text { Q9) Number of months } \\
\text { disability }\end{array}$} & Average Value & 1.23 & 3.34 & 0.31 & 1.58 & 0.75 & 2.57 & 1.08 & 0.68 & 0.90 & 2.24 & 1.28 \\
\hline & Frequency Count & 168 & 65 & 96 & 38 & 171 & 83 & 144 & 47 & 579 & 233 & 812 \\
\hline \multirow{2}{*}{$\begin{array}{l}\text { Q9) Number of months } \\
\text { retirement }\end{array}$} & Average Value & 0.17 & 1.43 & 1.56 & 1.58 & 0.37 & 0.72 & 1.06 & 1.30 & 0.68 & 1.18 & 0.82 \\
\hline & Frequency Count & 168 & 65 & 96 & 38 & 17.1 & 83 & 144 & 47 & 579 & 233 & 812 \\
\hline \multirow{2}{*}{$\begin{array}{l}\text { Q9) Number of months } \\
\text { in jail }\end{array}$} & Average Value & 0.17 & 7.63 & 0.94 & 4.00 & 1.11 & 4.52 & 1.04 & 6.64 & 0.79 & 5.73 & 2.21 \\
\hline & Frequency Count & 168 & 65 & 96 & 38 & 171 & 83 & 144 & 47 & 579 & 233 & 812 \\
\hline \multirow{2}{*}{$\begin{array}{l}\text { Tenure in months at } \\
\text { current job }\end{array}$} & Average Value & 61.04 & 65.51 & 74.30 & 51.61 & 58.75 & 57.61 & 68.60 & 71.28 & 64.49 & 61.81 & 63.72 \\
\hline & Frequency Count & 158 & 63 & 92 & 36 & 160 & 72 & 136 & 46 & 546 & 217 & 763 \\
\hline \multirow{2}{*}{$\begin{array}{l}\text { Q11e)1-way commute } \\
\text { (miles)/current job }\end{array}$} & Average Value & 15.57 & 15.33 & 19.46 & 22.00 & 18.22 & 17.43 & 15.24 & 10.96 & 16.92 & 16.19 & 16.71 \\
\hline & Frequency Count & 155 & 62 & 92 & 36 & 154 & 68 & 133 & 46 & 534 & 212 & 746 \\
\hline \multirow{2}{*}{$\begin{array}{l}\text { 011g)Weekly hours } \\
\text { worked/current job }\end{array}$} & Average Value & 43.77 & 43.69 & 45.91 & 46.44 & 44.81 & 44.13 & 44.27 & 44.22 & 44.56 & 44.41 & 44.52 \\
\hline & Frequency Count & 157 & 62 & 92 & 36 & 159 & 72 & 136 & 46 & 544 & 216 & 760 \\
\hline \multirow{2}{*}{$\begin{array}{l}\text { Q11h)Weekly gross } \\
\text { earnings/current } \\
\text { job }\end{array}$} & Average Value & 636.36 & 566.60 & 720.74 & 603.09 & 974.95 & 894.85 & 586.70 & 542.96 & 734.11 & 675.08 & 717.40 \\
\hline & Frequency Count & 150 & 57 & 90 & 33 & 143 & 66 & 126 & 45 & 509 & 201 & 710 \\
\hline
\end{tabular}


Effects of Administrative License Revocation on Employment

Tabulation by State, offender Type, and Total

Average Value and Frequency Count for Cońtinuous Variables

\begin{tabular}{|c|c|c|c|c|c|c|c|c|c|c|c|c|}
\hline & & \multicolumn{8}{|c|}{ STATE } & \multirow{2}{*}{\multicolumn{2}{|c|}{ Total }} & \multirow[b]{4}{*}{ Total } \\
\hline & & \multicolumn{2}{|c|}{ Pennsylvania } & \multicolumn{2}{|c|}{ Maryl and } & \multicolumn{2}{|c|}{ California } & \multicolumn{2}{|c|}{ Delaware } & & & \\
\hline & & \multicolumn{2}{|c|}{ OFFENDER TYPE } & \multicolumn{2}{|c|}{ OFFENDER TYPE } & \multicolumn{2}{|c|}{ OFFENDER TYPE } & \multicolumn{2}{|c|}{ OFFENDER TYPE } & \multicolumn{2}{|c|}{ OFFENDER TYPE } & \\
\hline & & First & Mult iple & First & Mult iple & First & Mult iple & First & Multiple & First & Multiple & \\
\hline \multirow{2}{*}{$\begin{array}{l}\text { Tenure in months } \\
\text { (next most recent } \\
\text { job) }\end{array}$} & Average Value & 23.05 & 23.77 & 23.81 & 13.73 & 40.24 & 30.86 & 30.70 & 42.67 & 29.75 & 27.09 & 29.00 \\
\hline & Frequency Count & 57 & 26 & 31 & 15 & 50 & 14 & 43 & 15 & 181 & 70 & 251 \\
\hline \multirow{2}{*}{$\begin{array}{l}\text { Q12e)1-way commute } \\
\text { (miles)/next job }\end{array}$} & Average Value & 14.40 & 10.26 & 15.32 & 17.86 & 12.01 & 15.81 & 12.30 & 8.86 & 13.40 & 12.63 & 13.19 \\
\hline & Frequency Count & 57 & 26 & 30 & 14 & 50 & 13 & 41 & 14 & 178 & 67 & 245 \\
\hline \multirow{2}{*}{$\begin{array}{l}\text { Q12g) Heekly hours } \\
\text { worked/next job }\end{array}$} & Average Value & 35.42 & 40.31 & 37.71 & 40.87 & 39.38 & 39.71 & 38.02 & 42.73 & 37.52 & 40.83 & 38.45 \\
\hline & Frequency Count & 57 & 26 & 31 & 15 & 50 & 14 & 42 & 15 & 180 & 70 & 250 \\
\hline \multirow{2}{*}{$\begin{array}{l}\text { Q12h) Weekly gross } \\
\text { earnings/next job }\end{array}$} & Average Value & 392.15 & 408.08 & 377.19 & 354.64 & 662.91 & 597.31 & 403.00 & 417.33 & 464.81 & 435.70 & 456.62 \\
\hline & Frequency Count & 54 & 25 & 31 & 14 & 46 & 13 & 40 & 15 & 171 & 67 & 238 \\
\hline
\end{tabular}


Effects of Administrative License Revocation on Employment

Iabulation by State, Offender Type, and Total
Average Value and Frequency Count for Cont inuous Variables

\begin{tabular}{|c|c|c|c|c|c|c|c|c|c|c|c|c|}
\hline \multirow{6}{*}{ | } & & \multicolumn{8}{|c|}{ STATE } & \multirow{2}{*}{\multicolumn{2}{|c|}{ Total }} & \multirow[b]{4}{*}{ Total } \\
\hline & & \multicolumn{2}{|c|}{ Pennsylvania } & \multicolumn{2}{|c|}{ Maryland } & \multicolumn{2}{|c|}{ Cal ifornia } & \multicolumn{2}{|c|}{ Delaware } & & & \\
\hline & & \multicolumn{2}{|c|}{ OFFENDER TYPE } & \multicolumn{2}{|c|}{ OFFENDER TYPE } & \multicolumn{2}{|c|}{ OFFENDER TYPE } & \multicolumn{2}{|c|}{ OFFENDER TYPE } & \multicolumn{2}{|c|}{ OFFENDER TYPE } & \\
\hline & & first & Multiple & First & Mult iple & First & Mult iple & First & Multiple & First & Multiple & \\
\hline & Average Value & 4.19 & 3.63 & 3.94 & 3.87 & 4.07 & 3.90 & 4.05 & 4.08 & 4.08 & 3.86 & 4.02 \\
\hline & Frequency Count & 128 & 46 & 81 & 30 & 141 & 61 & 115 & 40 & 465 & 177 & 642 \\
\hline \multirow{2}{*}{$\begin{array}{l}\text { 019)Extent income } \\
\text { redcd ( } 1=\text { not at } \\
\text { all })\end{array}$} & Average Value & 2.04 & 3.04 & 1.65 & 2.09 & 2.24 & 2.94 & 1.99 & 2.28 & 2.02 & 2.69 & 2.21 \\
\hline & Frequency Count & 135 & 52 & 82 & 32 & 146 & 68 & 118 & 40 & 481 & 192 & 673 \\
\hline \multirow{2}{*}{$\begin{array}{l}\text { Q20)\$/week income } \\
\text { reduced }\end{array}$} & Average Value & 69.57 & 65.63 & 46.83 & 79.03 & 155.80 & 223.84 & 36.77 & 77.07 & 83.23 & 125.71 & 94.88 \\
\hline & Frequency Count & 163 & 54 & 94 & 36 & 163 & 73 & 133 & 46 & 553 & 209 & 762 \\
\hline \multirow{2}{*}{$\begin{array}{l}\text { Age of car (in } \\
\text { years) }\end{array}$} & Average Value & 7.26 & 11.05 & 6.32 & 8.25 & 8.81 & 9.31 & 7.56 & 8.33 & $7.6: 3$ & 9.41 & 8.14 \\
\hline & Frequency Count & 166 & 61 & 93 & 36 & 166 & 80 & 141 & 46 & 566 & 223 & 789 \\
\hline \multirow{2}{*}{$\begin{array}{l}\text { Months from } \\
\text { suspension to } \\
\text { interview }\end{array}$} & Average Value & 4.22 & 7.81 & 5.70 & 6.96 & 4.16 & 8.15 & 6.99 & 15.40 & 5.04 & 9.47 & 6.34 \\
\hline & Frequency Count & 154 & 57 & 44 & 25 & 159 & 73 & 122 & 43 & 479 & 198 & 677 \\
\hline \multirow{2}{*}{$\begin{array}{l}\text { Q35)Days l icense } \\
\text { suspension will } \\
\text { last }\end{array}$} & Average Value & 149.77 & 492.27 & 114.39 & 272.73 & 163.01 & 570.14 & 294.87 & 515.43 & 186.76 & 501.94 & 280.13 \\
\hline & Frequency Count & 154 & 59 & 44 & 22 & 154 & 74 & 116 & 42 & 468 & 197 & 665 \\
\hline \multirow{2}{*}{$\begin{array}{l}\text { 036) Likely get lic } \\
\text { back (1=not at all) }\end{array}$} & Average Value & 4.48 & 4.33 & 4.73 & 3.58 & 4.59 & 4.15 & 4.54 & 4.36 & 4.56 & 4.18 & 4.44 \\
\hline & Frequency Count & 151 & 55 & 41 & 24 & 155 & 75 & 123 & 44 & 470 & 198 & 668 \\
\hline \multirow{2}{*}{$\begin{array}{l}\text { 037) Likely drive } \\
\text { w/o lic ( } 1=\text { not at } \\
\text { ali) }\end{array}$} & Average Value & 1.78 & 2.26 & 2.27 & 2.43 & 3.01 & 3.73 & 2.28 & 2.09 & 2.35 & 2.78 & 2.48 \\
\hline & Frequency Count & 157 & 58 & 44 & 28 & 154 & 75 & 123 & 45 & 478 & 206 & 684 \\
\hline \multirow{2}{*}{$\begin{array}{l}\text { 038) Likely caught } \\
\text { driving w/o lic }\end{array}$} & Average Value & 1.90 & 1.35 & 1.47 & 2.29 & 1.69 & 1.77 & 2.08 & 2.18 & 1.82 & 1.78 & 1.80 \\
\hline & Frequency Count & 42 & 23 & 15 & 7 & 90 & 57 & 50 & 17 & 197 & 104 & 301 \\
\hline \multirow{2}{*}{$\begin{array}{l}\text { Q39a) Interfrnc w/ } \\
\text { work (I=none) }\end{array}$} & Average value & 2.75 & 3.19 & 2.13 & 2.82 & 3.02 & 3.18 & 3.03 & 2.86 & 2.87 & 3.07 & 2.93 \\
\hline & Frequency Count & 119 & 48 & 32 & 17 & 145 & 72 & 107 & 44 & 403 & 181 & 584 \\
\hline \multirow{2}{*}{$\begin{array}{l}\text { Q39b) Interfrnc } w / \\
\text { social act ( } 1=\text { none) }\end{array}$} & Average Value & 3.56 & 3.85 & 3.53 & 3.22 & 3.61 & 3.69 & 3.89 & 3.55 & 3.66 & 3.65 & 3.66 \\
\hline & Frequency Count & 117 & 46 & 34 & 18 & 147 & 72 & 108 & 44 & 406 & 180 & 586 \\
\hline \multirow{2}{*}{$\begin{array}{l}\text { 039c) Interfrnc w/ } \\
\text { shopping ( }(=\text { =none) }\end{array}$} & Average Value & 3.08 & 3.42 & 3.03 & 3.17 & 3.33 & 3.29 & 3.50 & 3.09 & 3.28 & 3.26 & 3.27 \\
\hline & Frequency Count & 118 & 45 & 34 & 18 & 147 & 69 & 110 & 44 & 409 & 176 & 585 \\
\hline \multirow{2}{*}{$\begin{array}{l}\text { Q39d) Interfrnc w/ } \\
\text { medical app } \\
\text { (1=none) }\end{array}$} & Average Value & 2.35 & 3.22 & 2.50 & 2.72 & 2.63 & 3.12 & 2.90 & 2.73 & 2.61 & 3.01 & 2.73 \\
\hline & Frequency Count & 116 & 46 & 34 & 18 & 145 & 69 & 108 & 44 & 403 & 177 & 580 \\
\hline 039e)Interfrnc w/ & Average Value & 1.81 & 2.22 & 1.97 & 2.28 & 1.91 & 2.14 & 2.36 & 2.23 & 2.01 & 2.20 & 2.06 \\
\hline & Frequency Count & 117 & 45 & 33 & 18 & 142 & 66 & 108 & 44 & 400 & 173 & 573 \\
\hline Q41)Miles driven & Average Value & 17649.44 & 17122.95 & 25316.09 & 20808.82 & 17116.56 & 16212.86 & 21771.09 & 13142.86 & 19842.56 & 16613.04 & 18907.58 \\
\hline & Frequency Count & 142 & 61 & 87 & 34 & 151 & 70 & 128 & 42 & 508 & 207 & 715 \\
\hline Q42)Miles driven & Average Value & 188.63 & 108.58 & 500.02 & 235.71 & 202.81 & 155.83 & 125.78 & 98.37 & 228.91 & 143.18 & 203.81 \\
\hline & Frequency Count & 143 & 60 & 86 & 35 & 151 & 71 & 132 & 46 & 512 & 212 & 724 \\
\hline
\end{tabular}

(CONT I NUED) 
Tabulation by State, Offender Type, and Total

Average value and Frequency Count for Cont inuous Variables

\begin{tabular}{|c|c|c|c|c|c|c|c|c|c|c|c|c|}
\hline & & \multicolumn{8}{|c|}{ STATE } & \multirow{2}{*}{\multicolumn{2}{|c|}{ Total }} & \multirow[b]{4}{*}{ Total } \\
\hline & & \multicolumn{2}{|c|}{ Pennsylvania } & \multicolumn{2}{|c|}{ Maryland } & \multicolumn{2}{|c|}{ Cal ifornia } & \multicolumn{2}{|c|}{ Delaware } & & & \\
\hline & & \multicolumn{2}{|c|}{ OFFENDER TYPE } & \multicolumn{2}{|c|}{ OFFENDER TYPE } & \multicolumn{2}{|c|}{ OFFENDER TYPE } & \multicolumn{2}{|c|}{ OFFENDER TYPE } & \multicolumn{2}{|c|}{ OFFENDER TYPE } & \\
\hline & & First & Multiple & First & Mult iple & First & Mul tiple & First & Multiple & First & Multiple & \\
\hline \multirow[t]{2}{*}{ Age at interview } & Average value & 33.25 & 37.97 & 36.81 & 35.22 & 37.10 & 37.53 & 34.89 & 37.35 & 35.38 & 37.23 & 35.90 \\
\hline & Frequency Count & 159 & 57 & 94 & 35 & 157 & 77 & 137 & 44 & 547 & 213 & 760 \\
\hline
\end{tabular}


Effects of Administrative License Revocation on Employment Tabulation by State of questionnaire

on by State, Offender Type, and Total

\begin{tabular}{|c|c|c|c|c|c|c|c|c|c|c|c|c|}
\hline & & \multicolumn{8}{|c|}{ SIATE } & \multirow{2}{*}{\multicolumn{2}{|c|}{ Total }} & \multirow[b]{4}{*}{ Total } \\
\hline & & \multicolumn{2}{|c|}{ Pennsylvania } & \multicolumn{2}{|c|}{ Maryland } & \multicolumn{2}{|c|}{ California } & \multicolumn{2}{|c|}{ Delaware } & & & \\
\hline & & \multicolumn{2}{|c|}{ OFFENDER TYPE } & \multicolumn{2}{|c|}{ OFFENDER TYPE } & \multicolumn{2}{|c|}{ OFFENDER TYPE } & \multicolumn{2}{|c|}{ OFFENDER TYPE } & \multicolumn{2}{|c|}{ OFFENDER TYPE } & \\
\hline & & First & Multiple & First & Multiple & First & Multiple & First & Multiple & First & Multiple & \\
\hline \multirow[t]{2}{*}{ Age at DUI arrest } & Average Value & 32.55 & 36.75 & 36.16 & 34.61 & 36.69 & 36.73 & 34.14 & 36.13 & 34.76 & 36.26 & 35.18 \\
\hline & Frequency Count & 159 & 57 & 94 & 35 & 157 & 77 & 137 & 44 & 547 & 213 & 760 \\
\hline \multirow{2}{*}{$\begin{array}{l}\text { Q50)Comb. wkly } \\
\text { income of members } \\
\text { in home }\end{array}$} & Average Value & 1060.43 & 875.87 & 1041.91 & 1188.00 & 1260.16 & 1080.36 & 1112.88 & 617.08 & 1125.83 & 903.51 & 1064.15 \\
\hline & Frequency Count & 70 & 23 & 34 & 10 & 61 & 28 & 59 & 25 & 224 & 86 & 310 \\
\hline \multirow{2}{*}{$\begin{array}{l}\text { Q50)Comb. wkly inc } \\
\text { of household } \\
\text { (ave/HH) }\end{array}$} & Average Value & 743.43 & 647.61 & 831.99 & 585.50 & 880.10 & 909.82 & 682.46 & 478.81 & 778.03 & 676.69 & 749.92 \\
\hline & Frequency Count & 70 & 23 & 34 & 10 & 61 & 28 & 59 & 25 & 224 & 86 & 310 \\
\hline
\end{tabular}


Effects of Administrative License Revocation on Employment

Frequency Counts of Open-Ended Responses by state and Total

\begin{tabular}{|c|c|c|c|c|c|}
\hline \multirow{3}{*}{ Q2) COUNTY AND STATE OF RESIDENCE } & \multicolumn{4}{|c|}{ STATE } & \multirow[b]{2}{*}{ Total } \\
\hline & Pennsylvania & Maryl and & California & Delaware & \\
\hline & \multirow[b]{2}{*}{--} & \multirow[b]{2}{*}{--} & \multirow[b]{2}{*}{3} & \multirow[b]{2}{*}{$\cdots$} & \multirow[b]{2}{*}{3} \\
\hline CA & & & & & \\
\hline DE & -- & -- & -- & 2 & 2 \\
\hline $\mathrm{mo}$ & -- & 1 & -- & $\cdots$ & 1 \\
\hline PA & 4 & -- & -- & $\cdots$ & 4 \\
\hline Anne Arundel $\mathrm{MD}$ & $\because$ & 120 & -- & $\cdots$ & 120 \\
\hline Baltimore City MD & $\cdots$ & 2 & -- & $\cdots$ & 2 \\
\hline Baltimore MD & 1 & 2 & -- & 1 & 4 \\
\hline Bergen NJ & $\cdots$ & $\cdots$ & -- & 1 & 1 \\
\hline Berks PA & 3 & $\cdots$ & -- & - & 3 \\
\hline Cecil MD & -- & $\cdots$ & $\cdots$ & 6 & 6 \\
\hline Chester PA & 196 & $\cdots$ & -- & 4 & 200 \\
\hline Claymont DE & -- & $\cdots$ & $\cdots$ & 1 & 1 \\
\hline Contra Costa CA & $\cdots$ & $\cdots$ & 2 & $\cdots$ & 2 \\
\hline Delaware PA & 14 & -- & $\cdots$ & 7 & 21 \\
\hline Downingtown PA & 1 & $\cdots$ & -- & $\cdots$ & 1 \\
\hline Edge Water $m$ & $\cdots$ & 1 & $\cdots$ & - & 1 \\
\hline Essex MJ & $\cdots$ & -- & $\cdots$ & 1 & 1 \\
\hline Fairfax VA & -- & 1 & $\cdots$ & $\cdots$ & 1 \\
\hline Glenburnie MD & -- & 1 & $\cdots$ & $\cdots$ & 1 \\
\hline Kent DE & -- & $\cdots$ & $\cdots$ & 2 & 2 \\
\hline Lancaster PA & 2 & -- & $\cdots$ & $\cdots$ & 2 \\
\hline Marin CA & -- & $\cdots$ & 237 & $\cdots$ & 237 \\
\hline Mendoano CA & -- & $\cdots$ & 1 & -- & 1 \\
\hline Montgonery PA & 13 & $\cdots$ & $\cdots$ & -- & 13 \\
\hline New Castle DE & 2 & $\cdots$ & -- & 162 & 164 \\
\hline Newark DE & $\cdots$ & $\cdots$ & $\cdots$ & 3 & 3 \\
\hline Neuport & $\cdots$ & $\cdots$ & $\cdots$ & 1 & 1 \\
\hline Novato CA & $\cdots$ & $\cdots$ & 2 & -- & 2 \\
\hline Odessa DE & 1 & $\cdots$ & -- & $\cdots$ & 1 \\
\hline Pasail NJ & $\cdots$ & $\cdots$ & $\cdots$ & 1 & 1 \\
\hline Philadelphia PA & 1 & -- & $\cdots$ & 2 & 3 \\
\hline Phoenixville PA & 1 & $\cdots$ & $\cdots$ & -- & 1 \\
\hline Prince George's HD & $\cdots$ & 4 & $\cdots$ & $\cdots$ & 4 \\
\hline
\end{tabular}

(CONT INUED) 
Effects of Adninistrative License Revocation on Employment

Frequency Counts of Open-Ended Responses by state and Total

\begin{tabular}{|c|c|c|c|c|c|}
\hline & \multicolumn{4}{|c|}{ STATE } & \multirow[b]{2}{*}{ Total } \\
\hline & Pennsylvania & Maryl and & California & Delaware & \\
\hline \multicolumn{6}{|c|}{ QR) COUNTY AND STATE OF RESIOENCE } \\
\hline Queen Anne's mo & -- & 3 & -- & -- & 3 \\
\hline Salen MJ & 1 & -- & -- & -- & 1 \\
\hline San Francisco ca & $\cdots$ & -- & 3 & $\cdots$ & 3 \\
\hline Solano CA & $\cdots$ & $\cdots$ & 1 & $\cdots$ & 1 \\
\hline Sonoma ca & $\cdots$ & -- & 5 & $\ldots$ & 5 \\
\hline Sussex DE & -- & -- & -- & 2 & 2 \\
\hline Total & 240 & 135 & 254 & 196 & 825 \\
\hline
\end{tabular}


Effects of Adninistrative License Revocation on Employment

Frequency Counts of open-Ended Responses by state and Total

\begin{tabular}{|c|c|c|c|c|c|}
\hline & \multicolumn{4}{|c|}{ STATE } & \multirow[b]{2}{*}{ Total } \\
\hline & Pennsylvania & Maryland & California & Delaware & \\
\hline \multicolumn{6}{|l|}{ a3b)LOCATION OF MOST RECENT DUI ARREST } \\
\hline Annapol is, $\mathrm{ND}$ & -- & 30 & -- & $\cdots$ & 30 \\
\hline Anne Arundel County, m & -- & 14 & $\cdots$ & -- & 14 \\
\hline Arnold, mo & -- & 3 & $\cdots$ & -- & 3 \\
\hline Atglen, PA & 1 & -- & -- & -- & 1 \\
\hline Atlant ic County, NJ & 1 & -- & $\cdots$ & -- & 1 \\
\hline Avon Grove, PA & 1 & -- & $\cdots$ & -- & 1 \\
\hline Avondale, PA & 2 & $\cdots$ & $\cdots$ & -- & 2 \\
\hline Baltimore City, RD & -- & 1 & $\cdots$ & -- & 1 \\
\hline Baltimore, in & -- & 5 & $\cdots$ & $\cdots$ & 5 \\
\hline Bear, DE & $\cdots$ & $\cdots$ & -- & 6 & 6 \\
\hline Berwy, Easttown Tunshp., PA & 5 & -- & -- & $\cdots$ & 5 \\
\hline Beverly Beach(Anne Arundel) in & -- & 1 & $\cdots$ & $\cdots$ & 1 \\
\hline Birmingham Tornship, PA & 1 & $\cdots$ & $\cdots$ & -- & 1 \\
\hline Bol inas, Ca & $\cdots$ & $\cdots$ & 1 & -- & 1 \\
\hline Bowie, m & -- & 1 & $\cdots$ & -- & 1 \\
\hline Brandon, Tampa, FL & -- & -- & -- & 1 & 1 \\
\hline Brookhaven, PA & 1 & -- & -- & $\cdots$ & 1 \\
\hline Brooklyn Park, 10 & $\cdots$ & 2 & $\cdots$ & $\cdots$ & 2 \\
\hline ca & -- & $\cdots$ & 2 & -- & 2 \\
\hline Cal istoga, CA & -- & -- & 1 & $\cdots$ & 1 \\
\hline Caln Tounship, PA & 5 & -- & $\cdots$ & -- & 5 \\
\hline Canbridge, ID & $\cdots$ & 1 & -- & -- & 1 \\
\hline Cape Charles, va & -- & $\cdots$ & $\cdots$ & 1 & 1 \\
\hline Cape St. Clare & -- & 1 & $\cdots$ & -- & 1 \\
\hline Centerville, m & $\cdots$ & 1 & -- & -- & 1 \\
\hline Chester County, PA & 6 & $\cdots$ & -- & 2 & 8 \\
\hline Chester, PA & 2 & $\cdots$ & $\cdots$ & -- & 2 \\
\hline Chico, ca & -- & $\cdots$ & 1 & $\cdots$ & 1 \\
\hline Claymont, DE & -- & $\cdots$ & $\cdots$ & 12 & 12 \\
\hline Coatesville, PA & 8 & $\cdots$ & $\cdots$ & $\cdots$ & 8 \\
\hline Cochranville - Londonderry, PA & 1 & $\cdots$ & $\cdots$ & -- & 1 \\
\hline Colusa, CA & -- & $\cdots$ & 1 & $\cdots$ & 1 \\
\hline Concord Tunsp, DE County, PA & 1) & -- & -- & -- & 1 \\
\hline
\end{tabular}

(CONTIMUED) 
Effects of Administrative License Revocation on Employment

Frequency Counts of Open-Ended Responses by state and Total

\begin{tabular}{|c|c|c|c|c|c|}
\hline \multirow{3}{*}{ a3b)LOCATION OF MOST RECENT DUI ARREST } & \multicolumn{4}{|c|}{ STATE } & \multirow[b]{2}{*}{ Total } \\
\hline & Pennsylvania & Maryland & Cal ifornia & Delaware & \\
\hline & \multirow[b]{2}{*}{1} & \multirow[b]{2}{*}{.- } & \multirow[b]{2}{*}{$\cdots$} & \multirow[b]{2}{*}{--} & \multirow[b]{2}{*}{1} \\
\hline Concordvilte, DE County, PA & & & & & \\
\hline Corte Madera, CA & -- & -- & 15 & $\cdots$ & 15 \\
\hline Coventry, PA & 1 & -- & $\cdots$ & -- & 1 \\
\hline Crofton, MD' & $\cdots$ & 2 & $\cdots$ & -- & 2 \\
\hline Cumber land County, PA & 1 & -- & $\cdots$ & -- & 1 \\
\hline $\mathrm{DE}$ & $\cdots$ & -- & $\cdots$ & 1 & 1 \\
\hline Deale, Mo & -- & 3 & -- & $\cdots$ & 3 \\
\hline Delaware City, DE & -- & $\cdots$ & $\cdots$ & 1 & 1 \\
\hline Delaware County, PA & -- & -- & -- & 2 & 2 \\
\hline Devon, PA & 3 & -- & -- & -- & 3 \\
\hline District of Columbia & -- & 1 & -- & $\cdots$ & 1 \\
\hline Dorchester County, ND & $\cdots$ & 1 & $\cdots$ & -- & 1 \\
\hline Dover, DE & -- & $\cdots$ & -- & 1 & 1 \\
\hline Downingtown, PA & 10 & -- & -- & -- & 10 \\
\hline Durham, NC & --1 & 1 & $\cdots$ & $\cdots$ & 1 \\
\hline E. Coventry TS (Pottstown), PA & 1 & $\cdots$ & $\cdots$ & -- & 1 \\
\hline E. Pikel and Twp, (Spring Cty)PA & 1 & $\cdots$ & -- & -- & 1 \\
\hline Eagle, PA & 1 & $\cdots$ & -- & -- & 1 \\
\hline East Bradford Township, PA & $\cdots 1$ & -- & -- & -- & 1 \\
\hline East Fallowfield Township, PA & 4 & $\cdots$ & $\cdots$ & $\cdots$ & 4 \\
\hline East Goshen Townsh ip, PA & 5 & $-\cdot$ & -- & $\cdots$ & 5 \\
\hline East Whiteland Township, PA & 9 & $\cdots$ & -- & $\cdots$ & 9 \\
\hline Easton, $\mathrm{MD}$ & -- & 1 & $\cdots$ & $-\cdot$ & 1 \\
\hline Edgewater, MD & -- & 6 & -- & -- & 6 \\
\hline Elkton, MD & 1 & $\cdots$ & $-\infty$ & 1 & 2 \\
\hline Elsmere, DE & $\cdots$ & -- & - & 5 & 5 \\
\hline Elverson, PA & 1 & $\cdots$ & $\cdots$ & -- & 1 \\
\hline Exton, $P A$ & 1 & $\cdots$ & $-\infty$ & $\cdots$ & 1 \\
\hline Fairfax, CA &.- & -- & 16 & -- & 16 \\
\hline Frankl in Township, MJ & 1 & $\cdots$ & -- & $\cdots$ & 1 \\
\hline Galena, MD & -- & -- & -- & 1 & 1 \\
\hline Gambrills, MD & -- & 1 & $\ldots$ & $\cdots$ & 1 \\
\hline Gettysburg, PA & 1 & - & $\cdots$ & -- & 1 \\
\hline
\end{tabular}

(CONT IMUED) 
Effects of Administrative License Revocation on Employment

Frequency Counts of Open-Ended Responses by state and Total

\begin{tabular}{|c|c|c|c|c|c|}
\hline & \multicolumn{4}{|c|}{ STATE } & \multirow[b]{2}{*}{ Total } \\
\hline & Pennsylvania & Maryland & Cal ifornia & Delaware & \\
\hline \multicolumn{6}{|l|}{ Q3b)LOCATION OF MOST RECENT DUI ARREST } \\
\hline Glen Burnie, MD & $\cdots$ & 20 & -- & -- & 20 \\
\hline Glen Moore, PA & 1 & -- & $\cdots$ & -- & 1 \\
\hline Gloucester County, MJ & -- & $\because$ & $\cdots$ & 1 & 1 \\
\hline Greenbrae, CA & -- & $\cdots$ & 4 & -- & 4 \\
\hline Harrington, DE & -- & -- & $\cdots$ & 1 () & 1 \\
\hline Harrisburg, PA & -- & 1 & $\cdots$ & -- & 1 \\
\hline Harrison Tounship, MJ & -- & -- & $\cdots$ & 1 & 1 \\
\hline Harwood, MD & $\cdots$ & 1 & -- & $\cdots$ & 1 \\
\hline Hawa i i & -- & -- & 1. & $\cdots$ & 1 \\
\hline Hayward, Alameda County, CA & -- & -- & 1 & $\cdots$ & 1 \\
\hline Highland Township, PA & 1 & -- & -- & $\cdots$ & 1 \\
\hline Honeybrook Township, PA & 3 & -- & $\cdots$ & $\cdots$ & 3 \\
\hline Howard County, nd & $\cdots$ & 1 & $\cdots$ & -- & 1 \\
\hline Islamorada, Florida & -- & 1 & $\cdots$ & $\cdots$ & 1 \\
\hline Jackson Township, PA & 1 & -- & $\cdots$ & -- & 1 \\
\hline Kaol in, PA & 2 & -- & $\cdots$ & --1 & 2 \\
\hline Kennet t Square, PA & 1 & -- & $\cdots$ & -- & 1 \\
\hline Kent County, PA & 1 & -- & -- & -- & 1 \\
\hline Kentfield, CA & $\cdots$ & $\cdots$ & 1 & $\cdots$ & 1 \\
\hline Lake Tahoe, CA & $\cdots$ & $\because-$ & 1 & $\cdots$ & 1 \\
\hline Lancaster County, PA & 2 & $\cdots$ & -- & -- & 2 \\
\hline Landsdale, PA & 1 & $\cdots$ & -- & $\cdots$ & 1 \\
\hline Larkspur, CA & -- & -- & 17 & - & 17 \\
\hline Laurel，MD & -- & 2 & -- & $\cdots$ & 2 \\
\hline Lewes, DE & -- & $\cdots$ & -- & 1 & 1 \\
\hline Linthicum, MD & -- & 3 & $\cdots$ & -- & 3 \\
\hline Lothian, MD & -- & 1 & $\cdots$ & -- & 1 \\
\hline Lower Oxford, PA & 1 & $\cdots$ & -- & $-\cdot$ & 1 \\
\hline Lower Paxton Township, PA & 1. & -- & -- & $\because$ & 1 \\
\hline Lower Pottsgrove Township, PA & 1 & $\cdots$ & -- & $\cdots$ & 1 \\
\hline MD & -- & 1 & $\cdots$ & -- & 1 \\
\hline Malvern, PA & 11 & $\cdots$ & - & -- & 11 \\
\hline Margate, MJ & --1 & $\cdots$ & -- & 1 & 1 \\
\hline
\end{tabular}

(CONT INUED) 
Effects of Administrative License Revocation on Employment Frequency Counts of Open-Ended Responses by state and Total

\begin{tabular}{|c|c|c|c|c|c|}
\hline \multirow{3}{*}{ Q3b)LOCATION OF MOST RECENT DUI ARREST } & \multicolumn{4}{|c|}{ STATE } & \multirow[b]{2}{*}{ Total } \\
\hline & Pennsylvania & Maryland & California & Delaware & \\
\hline & \multirow[b]{2}{*}{--} & \multirow[b]{2}{*}{--} & \multirow[b]{2}{*}{8} & \multirow[b]{2}{*}{--} & \multirow[b]{2}{*}{8} \\
\hline Marin, CA & & & & & \\
\hline Mayo, MD & -- & 2 & $\cdots$ & -- & 2 \\
\hline Media, PA & 1 & -- & $\cdots$ & $\cdots$ & 1 \\
\hline Middletown, DE & -- & $\cdots$ & $\cdots$ & 5 & 5 \\
\hline Mill Valley, CA & $\cdots$ & $\cdots$ & 32 & -- & 32 \\
\hline Montchamin, DE & -- & -- & $\cdots$ & 1 & 1 \\
\hline Monterey, CA & $\cdots$ & -- & 1 & -- & 1 \\
\hline Montgomery County, PA & 1 & $\cdots$ & -- & -- & 1 \\
\hline Moraga, CA & $\cdots$ & -- & 1 & -- & 1 \\
\hline Napa, CA & $\cdots$ & -- & 2 & $\cdots$ & 2 \\
\hline Hew Castle County, DE & $\cdots$ & -- & $\cdots$ & 11 & 11 \\
\hline Hew Castle, DE & -- & -- & $\cdots$ & 29 & 29 \\
\hline Mew Jersey & $\cdots$ & $\cdots$ & $\cdots$ & 1 & 1 \\
\hline Mewark, DE & $\cdots$ & $\cdots$ & $\cdots$ & 29 & 29 \\
\hline Newport, DE & -- & -- & -- & 5 & 5 \\
\hline Norristown, PA & 1 & -- & -- & -- & 1 \\
\hline North Coventry Township, PA & 6 & -- & -- & $\cdots$ & 6 \\
\hline Novato, CA & $\cdots$ & $\cdots$ & 35 & $\cdots$ & 35 \\
\hline Ocean City, MD & $\therefore$ & 1 & $\cdots$ & 1 & 2 \\
\hline Odenton, MD & $\cdots$ & 2 & $\cdots$ & $\cdots$ & 2 \\
\hline Odessa, DE & 1 & -- & $\cdots$ & 1 & 2 \\
\hline Old New Castle, DE & -- & -- & -- & 2 & 2 \\
\hline Oxford Borough, PA & 3 & $\cdots$ & $\cdots$ & -- & $\overline{3}$ \\
\hline Paoli, PA & 4 & $\cdots$ & -- & $-\cdot$ & 4 \\
\hline Parkesburg, PA & 1 & -- & $\cdots$ & -- & 1 \\
\hline Pasadena, MD & $\cdots$ & 9 & -- & -- & 9 \\
\hline Pennel os County, FL & -- & $\cdots$ & -- & 1 & 1 \\
\hline Pennsbury Township, PA & 1 & $\cdots$ & -- & $\cdots$ & 1 \\
\hline Petaluma, CA & $\cdots$ & -- & 2 & -- & 2 \\
\hline Phoenixville, PA & 7 & $\cdots$ & -- & $\cdots$ & 7 \\
\hline Point Reyes Station, CA & -- & $\cdots$ & 1 & $\cdots$ & 1 \\
\hline Pottstown, PA & 2 & $\cdots$ & -- & $\cdots$ & 2 \\
\hline Prince Frederick, MD & $\cdots$ & 1 & $\cdots$ & $\cdots$ & 1 \\
\hline
\end{tabular}

(CONT IHUED) 
Effects of Administrative License Revocation on Employment

Frequency Counts of Open-Ended Responses by state and Total

\begin{tabular}{|c|c|c|c|c|c|}
\hline & \multicolumn{4}{|c|}{ STATE } & \multirow[b]{2}{*}{ Total } \\
\hline & Pennsylvania & Maryland & California & Delaware & \\
\hline \multicolumn{6}{|c|}{ (Q3b)LOCATION OF MOST RECENT DUI ARREST } \\
\hline Prince George's County, MD & $\cdots$ & 1 & $\cdots$ & -- & 1 \\
\hline Pt. Pleasant, PA & - & 1 & $\cdots$ & -- & 1 \\
\hline Radnor Tounship, PA & 1 & $\cdots$ & $\cdots$ & $\cdots$ & 1 \\
\hline Redwood City, ca & $\cdots$ & $-\cdot$ & 1 & -- & 1 \\
\hline Richmond, CA & -- & $\cdots$ & 1 & -- & 1 \\
\hline Riva, Mo & $\cdots$ & 1 & $\cdots$ & -- & 1 \\
\hline Romanville/Strausburg, PA & 1 & $\cdots$ & $\cdots$ & -- & 1 \\
\hline Ross, CA & $\cdots$ & $\because$ & 1 & -- & 1 \\
\hline Sadsburg, PA & 1 & $\cdots$ & -- & -- & 1 \\
\hline Salen, MA & -- & -- & 1 & $\cdots$ & 1 \\
\hline San Anselmo, CA & $\cdots$ & $\cdots$ & 9 & -- & 9 \\
\hline San Francisco, CA & -- & $\because$ & 12 & $\cdots$ & 12 \\
\hline San Mateo, Ca & -- & -- & 1. & -- & 1 \\
\hline San Rafael, CA & -- & $\cdots$ & 42 & -- & 42 \\
\hline Santa Barbara, CA & $\because$ & -- & 1 & $-\cdot$ & 1 \\
\hline Santa Rosa, CA & $\cdots$ & $\cdots$ & 1. & $\cdots$ & 1 \\
\hline Sausal ito, ca & $\cdots$ & $\cdots$ & 23 & -- & 23 \\
\hline Senner, CA & $\cdots$ & $\because$ & 1 & -- & 1 \\
\hline Severna Park, mD & $\cdots$ & 2 & $\cdots$ & -- & 2 \\
\hline Solomons Island, MD & $\cdots$ & 1 & $\cdots$ & -- & 1 \\
\hline Sonoma, CA & $\because$ & -- & 3 & -- & 3 \\
\hline Spring City, PA & 5 & $\cdots$ & $\cdots$ & $\cdots$ & 5 \\
\hline Stanton, DE & $\cdots$ & $\cdots$ & -- & 1 & 1 \\
\hline Stevensville, mo & $\cdots$ & 1 & $\cdots$ & $\cdots$ & 1 \\
\hline Stockton, CA & $\cdots$ & $\cdots$ & 1 & -- & 1 \\
\hline Strat ford, PA & 1 & $\cdots$ & $\cdots$ & $\because$ & 1 \\
\hline Summit Bridge, DE & - & -- & - & 1 & 1 \\
\hline Surf City, MJ & 1 & $\cdots$ & -- & -- & 1 \\
\hline Sussex County, DE & $\cdots$ & $\cdots$ & -- & 1 & 1 \\
\hline Tahoe City, CA & $\cdots$ & $\cdots$ & 1. & $\cdots$ & 1 \\
\hline Terra Linda, CA & $\cdots$ & $\cdots$ & 1 & $-\cdot$ & 1 \\
\hline Tiburon, CA & $\cdots$ & -- & 4 & -- & 4 \\
\hline Tredyffrin Township. PA & 21 & --1 & $\cdots$ & $\cdots$ & 21 \\
\hline
\end{tabular}


Effects of Administrative License Revocation on Employment

Frequency Counts of Open-Ended Responses by state and Total

\begin{tabular}{|c|c|c|c|c|c|}
\hline & \multicolumn{4}{|c|}{ STATE } & \multirow[b]{2}{*}{ Totel } \\
\hline & Pennsylvania & Maryland & California & Delaware & \\
\hline \multicolumn{6}{|l|}{ O3b)LOCATION OF MOST RECENT DUI ARREST } \\
\hline Trooper, PA & 1 & -- & -- & -- & 1 \\
\hline Twin Cities, CA & -- & $\cdots$ & 2 & $\cdots$ & 2 \\
\hline Ukiah, CA & -- & $\cdots$ & 1 & - & 1 \\
\hline Upper Merion Township, PA & 1 & $\cdots$ & $\cdots$ & $\cdots$ & 1 \\
\hline Upper Providence, DE Co.. Pa & 1 & $\cdots$ & $\cdots$ & $\cdots$ & 1 \\
\hline Upper Providence, Mont. Co, PA & 1 & -- & -- & -- & 1 \\
\hline Uwchlan Township, PA & 1 & $\cdots$ & $\cdots$ & $\cdots$ & 1 \\
\hline Valley Forge, PA & 2 & -- & $\cdots$ & $\cdots$ & 2 \\
\hline Ventura (Los Angeles), CA & 1 & -- & $\cdots$ & -- & 1 \\
\hline UI lmington, DE & -- & $\cdots$ & -- & 1 & 1 \\
\hline Mashington Township, MJ & -- & $\cdots$ & $\cdots$ & 1 & 1 \\
\hline Mashington, DC & $\cdots$ & 1 & -- & -- & 1 \\
\hline Mayne, PA & 2 & $\cdots$ & -- & -- & 2 \\
\hline West Bradford Township, PA & 1 & $\cdots$ & $\cdots$ & $\cdots$ & 1 \\
\hline West Brandywine, PA & 1 & -- & -- & -- & 1 \\
\hline West Caln, PA & 1 & $\cdots$ & $\cdots$ & $\cdots$ & 1 \\
\hline West Chester, PA & 27 & -- & $\cdots$ & -- & 27 \\
\hline Uest Goshen Townsh ip, PA & 9 & $\cdots$ & $\cdots$ & -- & 9 \\
\hline West Grove, PA & 4 & -- & $\cdots$ & -- & 4 \\
\hline West Pikeland Tounship, PA & 1 & $\cdots$ & $-\cdot$ & $\cdots$ & 1 \\
\hline West Whiteland Tounship, PA & 3 & -- & $\cdots$ & $\cdots$ & 3 \\
\hline Westtown Township, PA & 7 & -- & $\cdots$ & $\cdots$ & 7 \\
\hline Willistown Tounship, PA & 4 & -- & $\cdots$ & -- & 4 \\
\hline Hilmington, DE & $\cdots$ & -- & $\cdots$ & 61 & 61 \\
\hline Total & 232 & 130 & 251 & 191 & 804 \\
\hline
\end{tabular}


Effects of Administrative License Revocation on Employment

Frequency Counts of Open-Ended Responses by state and Tota

\begin{tabular}{|c|c|c|c|c|c|}
\hline & & STA & & & \\
\hline & Pennsylvania & Maryland & California & Delamare & Total \\
\hline Q21b)VEHICLE DRIVING AT DUI ARREST & & & & & \\
\hline AMC Concord & -- & -- & $-\cdot$ & 1 & 1 \\
\hline AMC Hornet & -- & -- & $\cdots$ & 1 & 1 \\
\hline Acura & 3 & -- & $\cdots$ & -- & 3 \\
\hline Acura Integra & 2 & -- & $\cdots$ & 1 & 3 \\
\hline Acura Legend & -- & -- & 1 & 1 & 2 \\
\hline Al tima & -- & -- & 1 & $\cdots$ & 1 \\
\hline Audi & -- & -- & 3 & $\cdots$ & 3 \\
\hline Audi 100S & 1 & $\cdots$ & $\cdots$ & $\cdots$ & 1 \\
\hline BMH & $\cdots$ & $\cdots$ & 9 & $\cdots$ & 9 \\
\hline BMH 325 & $\cdots$ & -- & 1 & $\cdots$ & 1 \\
\hline BAH 735i & 1 & $\cdots$ & 1 & $\cdots$ & 2 \\
\hline Blazer & -- & 1 & $\cdots$ & 1 & 2 \\
\hline Buick & 9 & 1 & 1 & 5 & 16 \\
\hline Buick Electra 225 & 1 & $\cdots$ & -- & $\cdots$ & 1 \\
\hline Buick Regal & 1 & -- & $\cdots$ & 4 & 5 \\
\hline Buick Rivera & -- & $\cdots$ & -- & 1 & 1 \\
\hline Buick Skylark & 1 & 1 & -- & -- & 2 \\
\hline Buick Somerset & $\cdots$ & -- & $\cdots$ & 1 & 1 \\
\hline Buick Station Wagon & $\cdots$ & $\cdots$ & -- & 1 & 1 \\
\hline C30 & $\cdots$ & -- & $\cdots$ & 1 & 1 \\
\hline Cadillac & 5 & 2 & 2 & 1 & 10 \\
\hline Cadillac Deville & -- & $\cdots$ & 1 & 2 & 3 \\
\hline Cadil lac Eldorado & -- & $\cdots$ & $\cdots$ & 1 & 1 \\
\hline Cadillac Seville & -- & -- & 1 & -- & 1 \\
\hline Chevy & 9 & 5 & 12 & 13 & 39 \\
\hline Chevy $4 \times 4$ & 1 & $\cdots$ & -- & $\cdots$ & 1 \\
\hline Chevy Astro Minivan & 1 & $\cdots$ & 1 & $\cdots$ & 2 \\
\hline Chevy Berreta GT & 1 & $\cdots$ & $\cdots$ & -- & 1 \\
\hline Chevy Blazer & 4 & $\cdots$ & 3 & $\cdots$ & 7 \\
\hline Chevy Blazer S-10 & 2 & 1 & 2 & 1 & 6 \\
\hline chevy c-10 & -- & $\cdots$ & $\cdots$ & 1 & 1 \\
\hline Chevy Camaro & 5 & 1 & 3 & 2 & 11 \\
\hline Chevy Camaro Coupe & 1 & $\cdots$ & -- & -- & 1 \\
\hline
\end{tabular}

(CONTINUED) 
Effects of Administrative License Revocation on Employment

Frequency counts of Open-Ended Responses by state and Total

\begin{tabular}{|c|c|c|c|c|c|}
\hline & \multicolumn{4}{|c|}{ STATE } & \multirow[b]{2}{*}{ Total } \\
\hline & Pennsylvania & Maryland & California & Delaware & \\
\hline \multicolumn{6}{|l|}{ Q21b)VEHICLE DRIVING AT DUI ARREST } \\
\hline Chevy Camaro z-28 & -- & 1 & -- & $\cdots$ & 1 \\
\hline Chevy Caprice & $-\cdot$ & -- & 1 & -- & 1 \\
\hline Chevy Cavalier & 2 & $\cdots$ & -- & $\cdots$ & 2 \\
\hline Chery Celebrity & 1 & -- & -- & -- & 1 \\
\hline Chevy chevette & 1 & $\cdots$ & -- & 1 & $\overline{2}$ \\
\hline Chevy Corsica & $-\cdot$ & -- & -- & 1 & 1 \\
\hline Chevy Corvette & $\cdots$ & 2 & 3 & 1 & 6 \\
\hline Chevy El Camino & 1 & -- & -- & $\cdots$ & 1 \\
\hline CheVy GEO & 1 & $\cdots$ & -- & 1 & 2 \\
\hline Chevy GEO Metro & -- & - & 1 & $\ldots$ & 1 \\
\hline Chery GEO Prizm & 1 &.- & -- & --1 & 1 \\
\hline Chery GEO Storm & 3 & 1 & 1 & -- & 5 \\
\hline Chery GEO Tracker & -- & -- &.- & 1 & 1 \\
\hline Chevy Impala & 1 & $\cdots$ &.- &.- & 1 \\
\hline Chevy Lumina & 1 & 1 & -4 & $-\infty$ & 2 \\
\hline Chevy Mal ibu Classic & -- & $\cdots$ & $\cdots$ & 1 & 1 \\
\hline Chevy Monte Carlo & 1 & 2 & $\cdots$ & 1 & 4 \\
\hline Chew Nova & -- & 1 & -- & $\cdots$ & 1 \\
\hline Chery Pick-up & 2 & 1 & $\therefore$ & 4 & 7 \\
\hline Chevy Sedan & 1 & -1 & -- & $\ldots$ & 1 \\
\hline Chevy Station Magon & 1 & $\ldots$ & $\cdots$ & 1 & 2 \\
\hline Chevy Truck & 3 & 2 & 2 & 2 & 9 \\
\hline Chevy Truck s-110 & $\cdots$ & 1 & $\cdots$ & $\cdots$ & 1 \\
\hline Chevy U.S. Gov.Truck & 1 & $\ldots$ & $\cdots$ & -- & 1 \\
\hline Chevy 234 & 1 &.- & $\ldots$ & $\cdots$ & 1 \\
\hline Chrysler & 1 & 1 & 1 & 2 & 5 \\
\hline Chrysler LHS & 1 & $\cdots$ & -- & -- & 1 \\
\hline Chrysler Laser & 1 & -- & -- & $\cdots$ & 1 \\
\hline Chrysler Lebaron & 2 & 1 & 1 & -- & 4 \\
\hline Datsun & 3 & $\cdots$ & 2 & 1 & 6 \\
\hline Datsun $2802 x$ & -- & -- & -- & it & 1 \\
\hline Datsun Station Magon & 1 & $-\cdot$ & -- & $\cdots$ & 1 \\
\hline Dodge & 9 & 4 & 4 & 4 & 21 \\
\hline
\end{tabular}

(CONT INUED) 
Effects of Administrative License Revocation on Employment

Frequency Counts of Open-Ended Responses by state and Total

\begin{tabular}{|c|c|c|c|c|c|}
\hline & \multicolumn{4}{|c|}{ STATE } & \multirow[b]{2}{*}{ Total } \\
\hline & Pennsylvania & Maryl and & Cal ifornia & Delaware & \\
\hline \multicolumn{6}{|c|}{ Q21b)VEHICLE DRIVING AT DUI ARREST } \\
\hline Dodge Aires & 1 & -- & -- & $\cdots$ & 1 \\
\hline Dodge Colt & 1 & 2 & 2 & $\cdots$ & 5 \\
\hline Dodge Dakota Pick-up & -- & 1 & -- & 1 & 2 \\
\hline Dodge Daytona & -- & 2 & 1 & $\cdots$ & 3 \\
\hline Dodge Dust. Sundance & 1 & $\cdots$ & -- & $\cdots$ & 1 \\
\hline Dodge Lancer ES & 1 & $\cdots$ & -- & $\cdots$ & 1 \\
\hline Dodge Omni & 1 & $\cdots$ & -- & 1 & 2 \\
\hline Dodge Pick-up Truck & 1 & $\cdots$ & 1 & $\cdots$ & 2 \\
\hline Dodge Ram 50 & $\cdots$ & $\cdots$ & -- & 1 & 1 \\
\hline Dodge Shadou & 1 & -- & 1 & $-\cdot$ & 2 \\
\hline Dodge Spirit & $\cdots$ & $\cdots$ & $\cdots$ & 1 & 1 \\
\hline Dodge Steal th & 2 & -- & $\cdots$ & -- & 2 \\
\hline Dodge Van & -- & -- & 1 & 2 & 3 \\
\hline Eagle Premiere & 1 & $-\cdot$ & $\cdots$ & -- & 1 \\
\hline Eagle Talon & $\cdots$ & 1 & $\cdots$ & 1 & 2 \\
\hline Eagle Uagon & $\cdots$ & -- & 1 & $\cdots$ & 1 \\
\hline Ferrari & -- & -- & 1 & $\cdots$ & 1 \\
\hline Ferro & $\cdots$ & 1 & $\cdots$ & $\cdots$ & 1 \\
\hline Fiat Spyder & $\cdots$ & -- & 1 & $\cdots$ & 1 \\
\hline Ford & 16 & 11 & 11 & 14 & 52 \\
\hline Ford Bronco & 2 & -- & 2 & 7 & 11 \\
\hline Ford Bronco II & $\cdots$ & 1 & 3 & 1 & 5 \\
\hline Ford Escort & 2 & 2 & 1 & 2 & 7 \\
\hline Ford Escort GT & 1 & $\cdots$ & $\cdots$ & $\cdots$ & 1 \\
\hline Ford F-150 Pick-up & -- & 2 & $\cdots$ & 2 & 4 \\
\hline Ford F-250 Pick-up & 2 & 1 & 2 & 1 & 6 \\
\hline ford fairmont & 2 & $\cdots$ & $\cdots$ & -- & 2 \\
\hline Ford Falcon & $\cdots$ & $\cdots$ & $\cdots$ & 1 & 1 \\
\hline Ford Granada & 1 & $\cdots$ & $\cdots$ & $\cdots$ & 1 \\
\hline Ford Grand Marquis & $\cdots$ & 1 & $\cdots$ & $\cdots$ & 1 \\
\hline Ford Mustang & 2 & 2 & 3 & 1 & 8 \\
\hline Ford Mustang GT & 2 & 1 & $\cdots$ & 2 & 5 \\
\hline Ford Mustang LX & 1 & -- & -- & $\cdots$ & 1 \\
\hline
\end{tabular}

(CONT INUED) 
Effects of Administrative License Revocation on Employment Frequency Counts of Open-Ended Responses by state and Total

\begin{tabular}{|c|c|c|c|c|c|}
\hline & \multicolumn{4}{|c|}{ STATE } & \multirow[b]{2}{*}{ Total } \\
\hline & Pennsyl vania & Maryland & Cal ifornia & Delaware & \\
\hline \multicolumn{6}{|l|}{ Q21b)VEHICLE DRIVING AT DUI ARREST } \\
\hline Ford Pick-up Truck & 1 & 1 & 2 & 8 & 12 \\
\hline Ford Pinto & $\cdots$ & -- & $\cdots$ & 1 & 1 \\
\hline Ford Probe & $\cdots$ & 1 & -- & -- & 1 \\
\hline Ford Probe GT & $\cdots$ & -- & -- & 1 & 1 \\
\hline Ford Ranger & 1 & -- & 3 & 2 & 6 \\
\hline Ford Station Wagon & -- & 1 & $\cdots$ & $\cdots$ & 1 \\
\hline Ford T-Bird & -- & $\cdots$ & 1 & $\cdots$ & 1 \\
\hline Ford Taurus & -- & - & 2 & $\cdots$ & 2 \\
\hline Ford Tempo & 2 & 2 & $\cdots$ & 1 & 5 \\
\hline Ford Thunderbird & 1 & 1 & 4 & $\cdots$ & 6 \\
\hline Ford Truck & 3 & 2 & 3 & 1 & 9 \\
\hline Ford Van & 3 & 3 & $\cdots$ & 4 & 10 \\
\hline GMC & $\cdots$ & 1 & 1 & 1 & 3 \\
\hline GMC $4 \times 4$ & $\cdots$ & $\cdots$ & 1 & $\cdots$ & 1 \\
\hline GMC Jimmy S-15 & 1 & $\cdots$ & -- & -- & 1 \\
\hline Gic Pick-up & 1. & $\cdots$ & $\cdots$ & $\cdots$ & 1 \\
\hline GMC Suburban & 1 & 1 & $\cdots$ & $\cdots$ & 2 \\
\hline GMC Truck & $\cdots$ & 1 & $\cdots$ & 1 & 2 \\
\hline GMC Van & 1 & $\therefore$ & $\therefore$ & $\therefore$ & 1 \\
\hline Grand Cherokee & 1 & $\cdots$ & -- & $\cdots$ & 1 \\
\hline Harley D. XLS Rdster & 1 & $\cdots$ & $\cdots$ & $\cdots$ & 1 \\
\hline Honda & 3 & 1 & 12 & 3 & 19 \\
\hline Honda Accord & $\cdots$ & 1 & $\cdots$ & 2 & 3 \\
\hline Honda Accord DX & 1 & $-\cdot$ & $\cdots$ & $\cdots$ & 1 \\
\hline Honda CRX & 3 & $\cdots$ & $\cdots$ & -- & 3 \\
\hline Honda Civic & 2 & $\cdots$ & 1 & 1 & 4 \\
\hline Honda Civic CX & $\cdots$ & $\cdots$ & 1 & -- & $\overline{1}$ \\
\hline Honda Motorcycle & 1 & -- & $\cdots$ & 1 & 2 \\
\hline Honda Prelude & 2 & -- & 2 & -- & 4 \\
\hline Hyunda $i$ & 2 & 2 & 1 & $\cdots$ & 5 \\
\hline Hyunda i Excel & 1 & -- & -- & -- & 1 \\
\hline I-Mark & -- & 1 & $\cdots$ & -- & 1 \\
\hline Isuzu & 2 & -- & 1 & 2 & 5 \\
\hline
\end{tabular}

(CONTINUED) 
Effects of Administrative License Revocation on Employment

Frequency Counts of Open-Ended Responses by state and rotal

\begin{tabular}{|c|c|c|c|c|c|}
\hline & & STA & & & \\
\hline & Pennsylvania & Maryland & California & Delaware & Total \\
\hline Q21b)VEHICLE DRIVING AT DUI ARREST & & & & & \\
\hline Isuzu Trooper & 1 & $\cdots$ & -- & $\cdots$ & 1 \\
\hline Jaguar & $\cdots$ & $\cdots$ & 3 & -- & 3 \\
\hline Jeep & 2 & 1 & 6 & 4 & 13 \\
\hline Jeep CJ7 & $\cdots$ & $\cdots$ & 1 & 2 & 3 \\
\hline Jeep Cherokee & 2 & 1 & 2 & 1 & 6 \\
\hline Jeep Wrangler & 1 & 1 & 2 & 1 & 5 \\
\hline Lincoln & 1 & 1 & -- & 1 & 3 \\
\hline Lincoln Cont inental & 1 & -- & -- & $\cdots$ & 1 \\
\hline Lincoln Mark VIII & $\cdots$ & -- & 1 & -- & 1 \\
\hline Lincoln Mark VIII LS & $\cdots$ & -- & 1 & -- & 1 \\
\hline Lincoln Town Car & 1 & 1 & -- & -- & 2 \\
\hline MGB & 1 & -- & -- & -- & 1 \\
\hline Mazda & $\cdots$ & $\cdots$ & 6 & 4 & 10 \\
\hline Mazda 323 & $\cdots$ & 1 & $\cdots$ & -- & 1 \\
\hline Mazda 626 & 1 & -- & $\cdots$ & -- & 1 \\
\hline Mazda Pick-up & $\cdots$ & $\cdots$ & 1 & 1 & 2 \\
\hline Mazda RX7 & 2 & 1 & 2 & $\cdots$ & 5 \\
\hline Mercedes 3000 & $\cdots$ & -- & 1. & $\cdots$ & 1 \\
\hline Mercedes $560 \mathrm{SL}$ & $\cdots$ & -- & 1 & $\cdots$ & 1 \\
\hline Mercedes Benz & -- & 1 & 5 & $\cdots$ & 6 \\
\hline Mercury & $\cdots$ & 3 & 3 & 2 & 8 \\
\hline Mercury Cougar & -- & -- & $\cdots$ & 1 & 1 \\
\hline Mercury Cougar XR7 & $\cdots$ & $\cdots$ & $\cdots$ & 2 & 2 \\
\hline Mercury Lynx & $\cdots$ & 1 & 1 & -- & 2 \\
\hline Mercury Marquix & $\cdots$ & $\cdots$ & $\cdots$ & 1 & 1 \\
\hline Mercury Sable & $\cdots$ & -- & 1 & 1 & 2 \\
\hline Mercury Topaz & 1 & 1 & $\cdots$ & -- & 2 \\
\hline Mercury Tracer & 1 & $\cdots$ & $\cdots$ & $\cdots$ & 1 \\
\hline Mitsubishi & -- & -- & $\cdots$ & 2 & 2 \\
\hline Mitsubishi Diamante & $-\cdot$ & -- & 1 & -- & 1 \\
\hline Mitsubishi Eclipse & 1 & -- & -- & $\cdots$ & 1 \\
\hline Mitsubishi Mirage & $\cdots$ & 1 & -- & $\cdots$ & 1 \\
\hline Motorcycle & $\cdots$ & -- & -- & 1 & 1 \\
\hline
\end{tabular}

(CONTINUED) 
Effects of Adninistrative License Revocation on Employment

Frequency Counts of Open-Ended Responses by state and Total

\begin{tabular}{|c|c|c|c|c|c|c|}
\hline & \multicolumn{4}{|c|}{ STATE } & \multirow{2}{*}{\multicolumn{2}{|c|}{ Total }} \\
\hline & Pennsylvania & Maryland & Cal ifornia & Delamare & & \\
\hline (021b)VEHICLE DRIVING & \multirow[b]{2}{*}{5} & \multirow[b]{2}{*}{4} & \multirow[b]{2}{*}{10} & \multirow[b]{2}{*}{1} & \multirow{2}{*}{\multicolumn{2}{|c|}{20}} \\
\hline Nissan & & & & & & \\
\hline Nissan 2005x & $\cdots$ & $\cdots$ & -- & 1 & & 1 \\
\hline Nissan $4 \times 4$ & $\cdots$ & $\cdots$ & 1 & $\cdots$ & & 1 \\
\hline Nissan King Cab & 1 & $\cdots$ & -- & -- & & 1 \\
\hline Nissan Maxima & 1 & 1 & -- & $\cdots$ & & 2 \\
\hline Nissan Pathfinder & -- & $\cdots$ & $\cdots$ & 1 & & 1 \\
\hline Nissan Sentra & 1 & 1 & $\cdots$ & 2 & & 4 \\
\hline Nissan Stanza & -- & $\ldots$ & 1 & $\cdots$ & & 1 \\
\hline Nissan Truck & 1 & $\cdots$ & 1 & $\cdots$ & & 2 \\
\hline olds & 6 & 3 & 4 & 5 & 1 & 18 \\
\hline Olds Cutlass & -- & $\cdots$ & $\cdots$ & 1 & & 1 \\
\hline Olds Cut lass supreme & -- & -- & 1 & 1 & & 2 \\
\hline Olds Tornado & 1 & $\cdots$ & -- & $\cdots$ & & 1 \\
\hline Pick-up Truck & 1 & 4 & 1 & 2 & & 8 \\
\hline Plymouth & -- & $\cdots$ & -- & 1 & & 1 \\
\hline Plymouth Rel iant & 1 & 1 & $\cdots$ & $\cdots$ & & 2 \\
\hline Plymouth Sundance & 1 & 1 & $\cdots$ & $\cdots$ & & 2 \\
\hline Plymouth Voyager & 1 & -- & $\cdots$ & $\cdots$ & . & 1 \\
\hline Pontiac & 1 & 2 & 4 & 5 & 1 & 12 \\
\hline Pontiac Fiero & $\cdots$ & $\cdots$ & 1 & $\cdots$ & & 1 \\
\hline Pontiac Firebird & 1 & 1 & 1 & 3 & & 6 \\
\hline Pontiac Grand AM & 2 & 1 & -- & -- & & 3 \\
\hline Pontiac Grand Prix & 2 & 1 & $\cdots$ & $\cdots$ & & 3 \\
\hline Pontiac LaMans & 1 & -- & -- & 2 & & 3 \\
\hline Pontiac Monte Carlo & $\cdots$ & $\cdots$ & -- & 1 & & 1 \\
\hline Pontiac sunbird & -- & 1 & $\cdots$ & 2 & & 3 \\
\hline Porsche & 1 & $\cdots$ & 1 & $\cdots$ & & 2 \\
\hline Probe & -- & $\cdots$ & $\cdots$ & 1 & & 1 \\
\hline Q-45 Infinity & $\cdots$ & $\cdots$ & 1 & $\cdots$ & & 1 \\
\hline Renaul $t$ & 1 & $\cdots$ & 1 & 1 & & 3 \\
\hline Saab & -- & $\cdots$ & 1 & $\cdots$ & & 1 \\
\hline Saturn & 2 & 1 & 2 & $\cdots$ & & 5 \\
\hline Spectrum & -- & 1 & $\cdots$ & -- & & 1 \\
\hline
\end{tabular}

(CONT I HUED) 
Effects of Administrative License Revocation on Employment

Frequency Counts of Open-Ended Responses by State and Total

\begin{tabular}{|c|c|c|c|c|c|}
\hline & \multicolumn{4}{|c|}{ STATE } & \multirow[b]{2}{*}{ Total } \\
\hline & Pennsylvania & Maryland & Cal ifornia & Delaware & \\
\hline \multicolumn{6}{|c|}{ Q21b)VEHICLE DRIVING AT DUI ARREST } \\
\hline Subaru & -- & -- & 6 & 1 & 7 \\
\hline Subaru Brat Truck & 1 & $\cdots$ & $\cdots$ & -- & 1 \\
\hline Subaru Station Wagon & 1 & $\cdots$ & $\cdots$ & 1 & 2 \\
\hline Suzuki Samari & 1 & $\cdots$ & $\cdots$ & -- & 1 \\
\hline Thunderbird & 1 & $\cdots$ & $\cdots$ & -- & 1 \\
\hline Toyota & 6 & 2 & 21 & 6 & 35 \\
\hline Toyota $4 \times 4$ & -- & $\cdots$ & 1 & 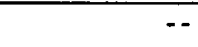 & 1 \\
\hline Toyota Canry & 1 & 1 & 2 & -- & 4 \\
\hline Toyota Celica & 1 & $\cdots$ & 1 & -- & 2 \\
\hline Toyota Corolla & $=-$ & 1 & 2 & $\cdots$ & 3 \\
\hline Toyote Cressida & -- & -- & 1 & $\cdots$ & $\overline{1}$ \\
\hline Toyota Pick-up & 2 & 2 & 6 & $\cdots$ & 10 \\
\hline Toyota Supra & $\cdots$ & 1 & -- & -- & $\overline{1}$ \\
\hline Toyota Tercel & 2 & 1 & -- & $\cdots$ & 3 \\
\hline Toyota Truck & 1 & 2 & $\cdots$ & $\cdots$ & 3 \\
\hline Truck & 1 & 2 & 1 & $\cdots$ & 4 \\
\hline vis & 4 & 1 & 5 & 1 & 11 \\
\hline W Beetle & 1 & $\cdots$ & $\cdots$ & $\cdots$ & $\overline{1}$ \\
\hline vw fox & $\cdots$ & $\cdots$ & $\cdots$ & 1 & 1 \\
\hline Wu Golf & $\cdots$ & 1 & $\cdots$ & $\cdots$ & $\overline{1}$ \\
\hline W Jetta & $\cdots$ & $\cdots$ & 2 & $\cdots$ & 2 \\
\hline Wu Rabbit & $\cdots$ & -- & 1 & -- & 1 \\
\hline VW Van & $\cdots$ & $\cdots$ & 2 & $\cdots$ & 2 \\
\hline Van & $\cdots$ & 1 & $\cdots$ & -- & 1 \\
\hline Volvo & $\cdots$ & 1 & 1 & 1 & 3 \\
\hline Volvo $740 \mathrm{DL}$ & 1 & $\cdots$ & $\cdots$ & $=$ & 1 \\
\hline Volvo Station Wagon & 1 & $\cdots$ & $\cdots$ & $\cdots$ & 1 \\
\hline Yanaha Cycle & 1 & $\cdots$ & $\cdots$ & -- & . \\
\hline Yugo & $\cdots$ & $\cdots$ & 2 & $\cdots$ & 2 \\
\hline Total & 236 & 130 & 247 & 193 & 806 \\
\hline
\end{tabular}


Effects of Administrative License Revocation on Employment

Frequency Counts of Changes in Employment and Income by State, Offender Type, and Total

\begin{tabular}{|c|c|c|c|c|c|c|c|c|c|c|c|}
\hline & \multicolumn{8}{|c|}{ STATE } & \multirow{2}{*}{\multicolumn{2}{|c|}{ Total }} & \multirow[b]{4}{*}{ Total } \\
\hline & \multicolumn{2}{|c|}{ Pennsylvania } & \multicolumn{2}{|c|}{ Maryland } & \multicolumn{2}{|c|}{ California } & \multicolumn{2}{|c|}{ Del aware } & & & \\
\hline & \multicolumn{2}{|c|}{ OFFENDER TYPE } & \multicolumn{2}{|c|}{ OFFENDER TYPE } & \multicolumn{2}{|c|}{ OFFENDER TYPE } & \multicolumn{2}{|c|}{ OFFENDER TYPE } & \multicolumn{2}{|c|}{ OFFENDER TYPE } & \\
\hline & First & Multiple & First & Multiple & First & Mul tiple & First & Multiple & First & Multiple & \\
\hline \multicolumn{12}{|l|}{ Q10)CHANGES IN EMPLOYMENT AND INCOME } \\
\hline \multirow[t]{2}{*}{ Answer left blank } & 25 & 14 & 13 & 4 & 24 & 15 & 22 & 5 & 84 & 38 & 122 \\
\hline & 12.8 & 18.4 & 12.6 & 10.0 & 12.5 & 14.2 & 13.3 & 9.6 & 12.8 & 13.9 & 13.1 \\
\hline N/A or none & 71 & 13 & 47 & 19 & 44 & 9 & 39 & 10 & 201 & 51 & 252 \\
\hline Column Percent & 36.2 & 17.1 & 45.6 & 47.5 & 22.9 & 8.5 & 23.5 & 19.2 & 30.6 & 18.6 & 27.1 \\
\hline None; cont inues to drive & 1 & 1 & $\cdots$ & 1 & 11 & 5 & 2 & -- & 14 & 7 & 21 \\
\hline Column Percent & 0.5 & 1.3 & $\cdots$ & 2.5 & 5.7 & 4.7 & 1.2 & $\cdots$ & 2.1 & 2.6 & 2.3 \\
\hline No change; recvd work restricted license & $\cdots$ & $\cdots$ & 6 & 1 & 3 & 1 & 2 & $\cdots$ & 11 & 2 & 13 \\
\hline Colum Percent & $\cdots$ & $-\cdot$ & 5.8 & 2.5 & 1.6 & 0.9 & 1.2 & -- & 1.7 & 0.7 & 1.4 \\
\hline Employer does not know & $\cdots$ & $\cdots$ & 1 & -- & 4 & 2 & 3 & $\cdots$ & 8 & 2 & 10 \\
\hline Column Percent & $\cdots$ & $\cdots$ & 1.0 & $\cdots$ & 2.1 & 1.9 & 1.8 & $\cdots$ & 1.2 & 0.7 & 1.1 \\
\hline Employment remained the same & 1 & -- & -- & 1 & 7 & 1 & 5 & -- & 13 & 2 & 15 \\
\hline Column Percent & 0.5 & $\cdots$ & $\cdots$ & 2.5 & 3.6 & 0.9 & 3.0 & $\cdots$ & 2.0 & 0.7 & 1.6 \\
\hline No change; transportation difficult & 16 & 4 & 7 & 1 & 11 & 8 & 26 & 9 & 60 & 22 & 82 \\
\hline Colum Percent & 8.2 & 5.3 & 6.8 & 2.5 & 5.7 & 7.5 & 15.7 & 17.3 & 9.1 & 8.0 & 8.8 \\
\hline More hours & 1 & $\cdots$ & 1 & -- & $\cdots$ & -- & 1 & -- & 3 & $\cdots$ & 3 \\
\hline Column Percent & 0.5 & -- & 1.0 & $\cdots$ & $\cdots$ & -- & 0.6 & $\cdots$ & 0.5 & $\cdots$ & 0.3 \\
\hline Self-improvement; time to attend $A A /$ rehab & $\cdots$ & 1 & $\because$ & $\cdots$ & -- & -- & $\because$ & $\therefore$ & $\cdots$ & 1 & 1 \\
\hline Colum Percent & $\cdots$ & 1.3 & -- & -- & $\cdots$ & -- & $\cdots$ & $\cdots$ & $\cdots$ & 0.4 & 0.1 \\
\hline Job change & 4 & 2 & 1 & 1 & $\cdots$ & $\cdots$ & $\cdots$ & 1 & 5 & 4 & 9 \\
\hline Column Percent & 2.0 & 2.6 & 1.0 & 2.5 & $\cdots$ & $\cdots$ & $\cdots$ & 1.9 & 0.8 & 1.5 & 1.0 \\
\hline Lost job & 7 & 8 & 4 & 2 & 13 & 9 & 3 & 7 & 27 & 26 & 53 \\
\hline Column Percent & 3.6 & 10.5 & 3.9 & 5.0 & 6.8 & 8.5 & 1.8 & 13.5 & 4.1 & 9.5 & 5.7 \\
\hline Lost job; license required & 1 & 2 & $\cdots$ & -- & $\cdots$ & $\cdots$ & 3 & 1 & 4 & 3 & 7 \\
\hline Column Percent & 0.5 & 2.6 & $\cdots$ & $\cdots$ & $\cdots$ & $\cdots$ & 1.8 & 1.9 & 0.6 & 1.1 & 0.8 \\
\hline Lost second job & 2 & $\cdots$ & $\cdots$ & -- & 1 & $\cdots$ & $\cdots$ & $\cdots$ & 3 & -- & 3 \\
\hline Colum Percent & 1.0 & +- & $\cdots$ & $\cdots$ & 0.5 & -- & $\cdots$ & $\cdots$ & 0.5 & $\cdots$ & 0.3 \\
\hline Quit; lack of transportation & $\cdots$ & 1 & $\cdots$ & $\cdots$ & -- & 2 & -- & 1 & $\cdots$ & 4 & 4 \\
\hline Column Percent & $\cdots$ & 1.3 & $\cdots$ & $\cdots$ & -- & 1.9 & $\cdots$ & 1.9 & $\cdots$ & 1.5 & 0.4 \\
\hline Changed jobs; loss of time due to court & $\cdots$ & 1 & -- & -- & $\cdots$ & $-\cdot$ & -- & -- & -- & 1 & 1 \\
\hline Column Percent & -- & 1.3 & $\cdots$ & -- & $\cdots$ & $\cdots$ & $\cdots$ & -- & $\cdots$ & 0.4 & 0.1 \\
\hline Changed jobs; lack of transportation & $\cdots$ & -- & -- & 2 & -- & $\cdots$ & $\cdots$ & -- & -- & 2 & 2 \\
\hline
\end{tabular}

(CONT INUED) 
Effects of Administrative License Revocat ion on Employment

Frequency Counts of Changes in Employment and Income by State, Offender Type, and Total

\begin{tabular}{|c|c|c|c|c|c|c|c|c|c|c|c|c|}
\hline & & \multicolumn{8}{|c|}{ STATE } & \multirow{2}{*}{\multicolumn{2}{|c|}{ Total }} & \multirow[b]{4}{*}{ Total } \\
\hline & & \multicolumn{2}{|c|}{ Pennsylvania } & \multicolumn{2}{|c|}{ Maryl and } & \multicolumn{2}{|c|}{ Cal ifornia } & \multicolumn{2}{|c|}{ Delaware } & & & \\
\hline & & \multicolumn{2}{|c|}{ OFFENDER TYPE } & \multicolumn{2}{|c|}{ OFFENDER TYPE } & \multicolumn{2}{|c|}{ OFFENDER TYPE } & \multicolumn{2}{|c|}{ OFFENDER TYPE } & \multicolumn{2}{|c|}{ OFFEMDER TYPE } & \\
\hline & & First & Multiple & First & Multiple & first & Multiple & First & Multiple & First & Multiple & \\
\hline \multicolumn{13}{|l|}{$\begin{array}{l}\text { Q10)CHAMGES IN } \\
\text { EMPLOYMENT AND INCONE }\end{array}$} \\
\hline $\begin{array}{l}\text { Changed jobs; lack of } \\
\text { transportat ion }\end{array}$ & Colum Percent & $\cdots$ & -- & - & 5.0 & -- & -- & -- & $\cdots$ & -- & 0.7 & 0.2 \\
\hline \multirow[t]{2}{*}{ Leave of absence } & & $\cdots$ & -- & $\cdots$ & $\cdots$ & 2 & -- & -- & $\cdots$ & 2 & $\cdots$ & 2 \\
\hline & Column Percent & $\cdots$ & -- & $\cdots$ & -- & 1.0 & -- & -- & -- & 0.3 & $\cdots$ & 0.2 \\
\hline \multicolumn{2}{|c|}{ Lost opportunities; lack of transportation } & 5 & 5 & 1 & 1 & 8 & 5 & 9 & 2 & 23 & 13 & 36 \\
\hline & Column Percent & 2.6 & 6.6 & 1.0 & 2.5 & 4.2 & 4.7 & 5.4 & 3.8 & 3.5 & 4.7 & 3.9 \\
\hline \multirow[t]{2}{*}{ Lost time/hours } & & 6 & 1 & 1 & 1 & -- & 1 & 5 & $\cdots$ & 12 & 3 & 15 \\
\hline & Column Percent & 3.1 & 1.3 & 1.0 & 2.5 & -- & 0.9 & 3.0 & -- & 1.8 & 1.1 & 1.6 \\
\hline \multicolumn{2}{|c|}{ Lost time due to court/treatment program } & $\cdots$ & -- & 4 & $\cdots$ & 1 & 3 & 1 & -- & 6 & 3 & 9 \\
\hline & Column Percent & -- & -- & 3.9 & $\cdots$ & 0.5 & 2.8 & 0.6 & $\cdots$ & 0.9 & 1.1 & 1.0 \\
\hline \multirow[t]{2}{*}{ Lost time due to class } & & 1 & 1 & 1 & $\cdots$ & 4 & 3 & 4 & $\cdots$ & 10 & 4 & 14 \\
\hline & Column Percent & 0.5 & 1.3 & 1.0 & $\cdots$ & 2.1 & 2.8 & 2.4 & $\cdots$ & 1.5 & 1.5 & 1.5 \\
\hline \multirow[t]{2}{*}{ Lost time due to jail } & & $\cdots$ & 1 & 1 & -- & $\cdots$ & 2 & 1 & 3 & 2 & 6 & 8 \\
\hline & Column Percent & -- & 1.3 & 1.0 & $\cdots$ & $\cdots$ & 1.9 & 0.6 & 5.8 & 0.3 & 2.2 & 0.9 \\
\hline \multicolumn{2}{|c|}{ Lost time due to lack of transportation } & 5 & 2 & 2 & 1 & 2 & 3 & 8 & 2 & 17 & 8 & 25 \\
\hline & Column Percent & 2.6 & 2.6 & 1.9 & 2.5 & 1.0 & 2.8 & 4.8 & 3.8 & 2.6 & 2.9 & 2.7 \\
\hline \multirow[t]{2}{*}{ Worked nore from home } & & $\cdots$ & -- & -- & $\cdots$ & 1 & 1 & -- & -- & 1 & 1 & 2 \\
\hline & Column Percent & $\cdots$ & -- & $\cdots$ & -- & 0.5 & 0.9 & $\cdots$ & $\cdots$ & 0.2 & 0.4 & 0.2 \\
\hline \multirow[t]{2}{*}{ Lost income } & & 10 & 6 & 2 & 2 & 9 & 11 & 3 & 4 & 24 & 23 & 47 \\
\hline & Column Percent & 5.1 & 7.9 & 1.9 & 5.0 & 4.7 & 10.4 & 1.8 & 7.7 & 3.7 & 8.4 & 5.0 \\
\hline \multicolumn{2}{|c|}{ Hours cut/shift change/lack of overt ime } & 3 & 2 & 1 & -- & 5 & 2 & 6 & 1 & 15 & 5 & 20 \\
\hline & Column Percent & 1.5 & 2.6 & 1.0 & -- & 2.6 & 1.9 & 3.6 & 1.9 & 2.3 & 1.8 & 2.1 \\
\hline \multirow[t]{2}{*}{ Suspension from job } & & 2 & $\cdots$ & 1 & $\cdots$ & $\cdots$ & 1 & 1 & $\cdots$ & 4 & 1 & 5 \\
\hline & Column Percent & 1.0 & -- & 1.0 & $\cdots$ & $\cdots$ & 0.9 & 0.6 & $\cdots$ & 0.6 & 0.4 & 0.5 \\
\hline \multicolumn{2}{|c|}{ Demotion and/or job change within company } & 8 & 3 & 1 & 1 & 1. & 1 & 3 & 3 & 13 & 8 & 21 \\
\hline & Column Percent & 4.1 & 3.9 & 1.0 & 2.5 & 0.5 & 0.9 & 1.8 & 5.8 & 2.0 & 2.9 & 2.3 \\
\hline Loss of promotion & & $\cdots$ & 1 & 1 & $\cdots$ & 2 & 2 & 2 & $\cdots$ & 5 & 3 & 8 \\
\hline & Colum Percent & $\cdots$ & 1.3 & 1.0 & $\cdots$ & 1.0 & 1.9 & 1.2 & -- & 0.8 & 1.1 & 0.9 \\
\hline Loss of out-of-town & $k_{;}$lost opportunity & 7 & 1 & 1 & 1 & 14 & 4 & 4 & $\cdots$ & 26 & 6 & 32 \\
\hline & Column Percent & 3.6 & 1.3 & 1.0 & 2.5 & 7.3 & 3.8 & 2.4 & $\cdots$ & 4.0 & 2.2 & 3.4 \\
\hline Pay cut & & 3 & 2 & $\cdots$ & -- & -- & --1 & 3 & $\cdots$ & 6 & 2 & 8 \\
\hline
\end{tabular}

\section{(CONT INUED )}


Effects of Adninistrative License Revocation on Empl oyment

Frequency Counts of Changes in Employment and Income by State, Offender Type, and Total

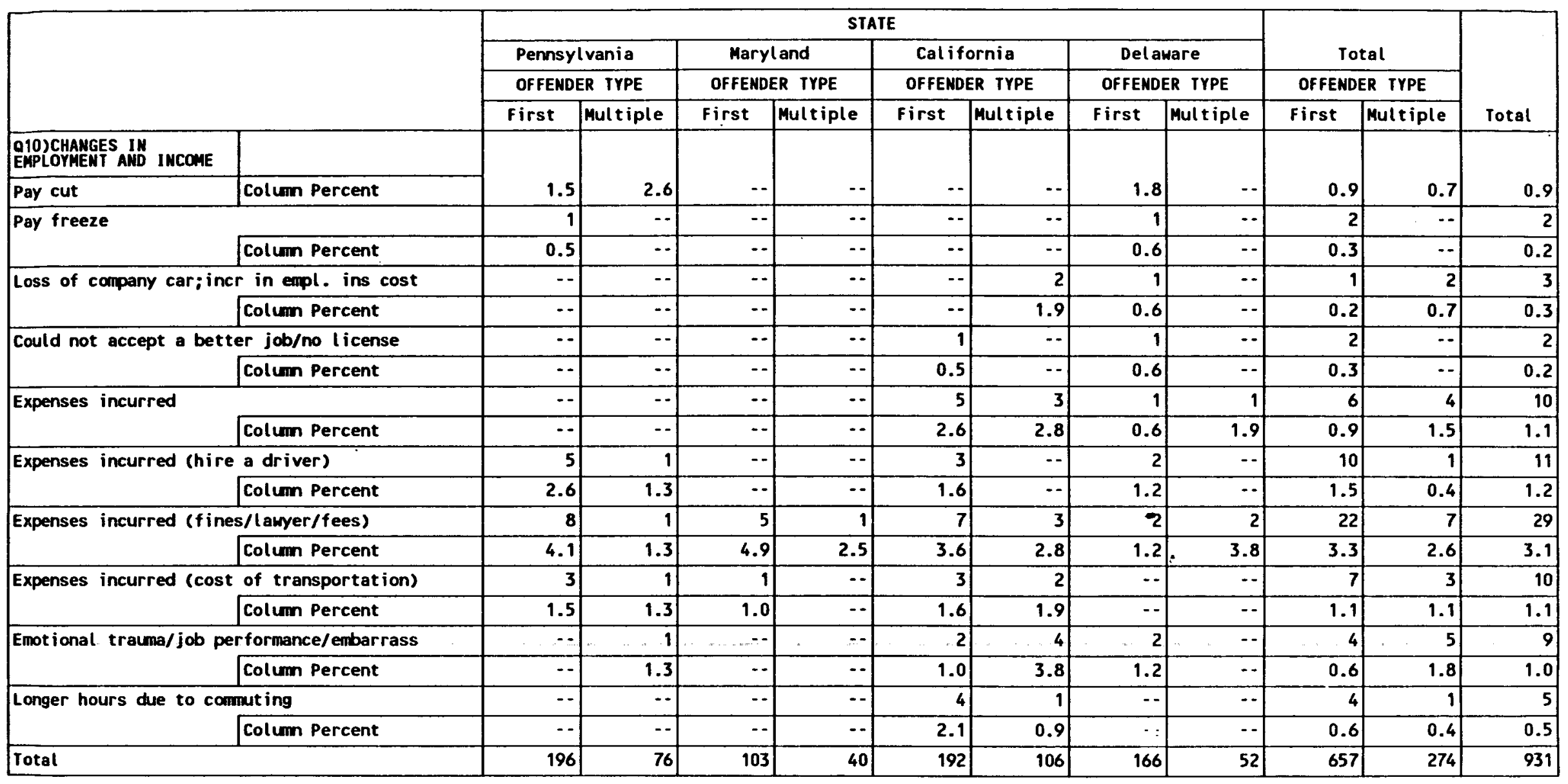




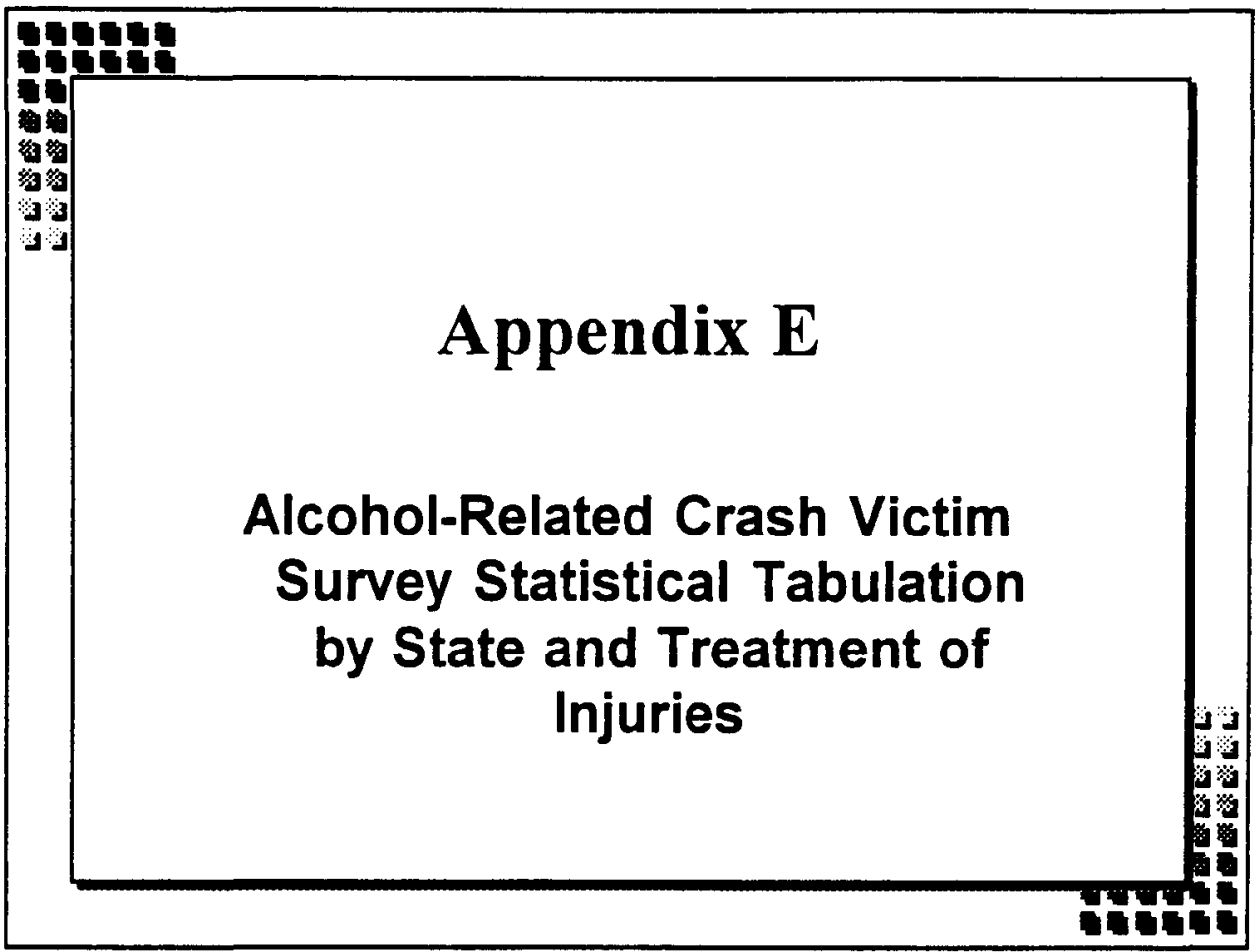




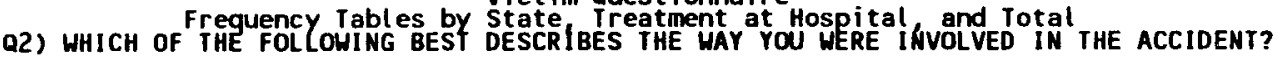

\begin{tabular}{|c|c|c|c|c|c|c|}
\hline & \multicolumn{3}{|c|}{ State of Accident } & \multicolumn{2}{|c|}{ Treatment of Injuries } & \multirow[b]{2}{*}{ Total } \\
\hline & \begin{tabular}{|r|} 
Pennsylvania \\
\end{tabular} & California & Delaware & $\begin{array}{l}\text { Not treated } \\
\text { at hospital }\end{array}$ & $\begin{array}{l}\text { Treated at } \\
\text { hospital }\end{array}$ & \\
\hline \multicolumn{7}{|l|}{ RESPONSE CATEGORY } \\
\hline $\begin{array}{l}\text { 2) I was a passenger in the vehicle of } \\
\text { a driver who was charged with DUl. }\end{array}$ & 2 & 4 & 2 & 3 & 5 & $\varepsilon$ \\
\hline Column Percent & 3.8 & 11.8 & 3.4 & 4.6 & 6.3 & 5.5 \\
\hline $\begin{array}{l}\text { 3) I was the driver of another vehicle } \\
\text { involved in the accident, and I was } \\
\text { not charged with Dul. }\end{array}$ & 43 & 21 & 46 & 57 & 53 & 110 \\
\hline Column Percent & 81.1 & 61.8 & 79.3 & 87.7 & 66.3 & 75.9 \\
\hline $\begin{array}{l}\text { 4) I was a passenger in a vehicle } \\
\text { invol ved in the accident, whose driver } \\
\text { was not charged with DUI. }\end{array}$ & 6 & 9 & 9 & 2 & 22 & 24 \\
\hline Column Percent & 11.3 & 26.5 & 15.5 & 3.1 & 27.5 & 16.6 \\
\hline 5) I was a pedestrian. & 2 & -- & 1 & 3 & $\cdots$ & 3 \\
\hline Column Percent & 3.8 & -- & 1.7 & 4.6 & $\cdots$ & 2.1 \\
\hline Total & 53 & 34 & 58 & 65 & 80 & 145 \\
\hline
\end{tabular}


Q3) WHICH OF THE FOLlOWING BESY DESCRIBES THE INJURIES You RECEIVED IN THE ACCIDENT?

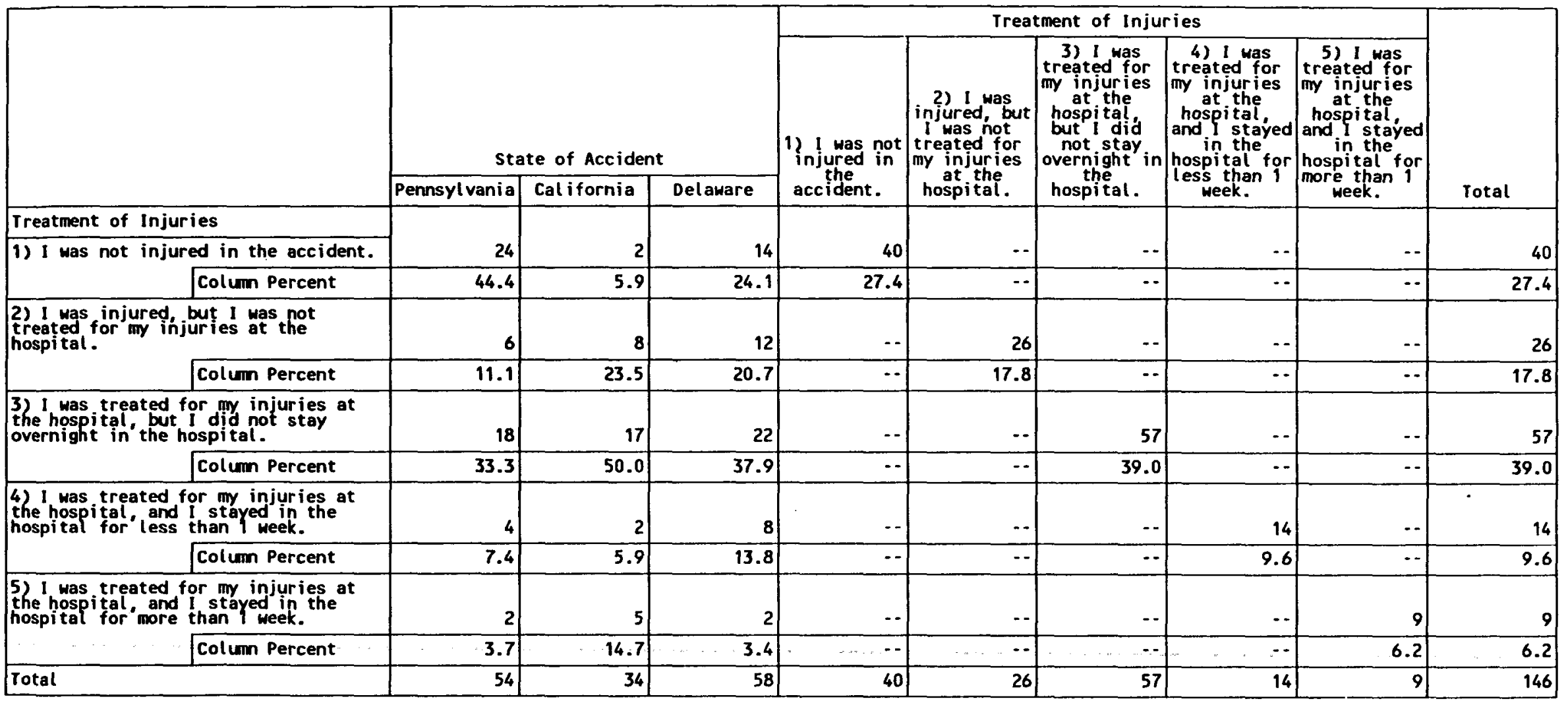


Effects of Administrative License Reyocation on Employment

Q4) UHICH OF THE FOLLOWING BEST DESCRIBES THE DAMAGE TO THE VEHICLE YbU RECULARLY DRIVE BECAUSE OF THE ACCIDENT?

\begin{tabular}{|c|c|c|c|c|c|c|}
\hline & \multicolumn{3}{|c|}{ State of Accident } & \multicolumn{2}{|c|}{ Treatment of Injuries } & \multirow[b]{2}{*}{ Total } \\
\hline & Pennsylvania & California & Delaware & $\begin{array}{l}\text { Not treated } \\
\text { at hospital }\end{array}$ & $\begin{array}{c}\text { Treated at } \\
\text { hospital }\end{array}$ & \\
\hline RESPONSE CATEGORY & & & & & & \\
\hline \multirow[t]{2}{*}{$\begin{array}{l}\text { 1) I do not drive } \\
\text { regular basis. }\end{array}$} & 1 & 4 & 1 & $-\cdot$ & 6 & 6 \\
\hline & 1.9 & 11.8 & 1.8 & $\cdots$ & 7.6 & 4.2 \\
\hline $\begin{array}{l}\text { 2) I had no loss of use of the vehicle } \\
\text { regularily drive because of the } \\
\text { accident. }\end{array}$ & 13 & 1 & 10 & 13 & 11 & 24 \\
\hline Column Percent & 24.5 & 2.9 & 17.5 & 20.0 & 13.9 & 16.7 \\
\hline $\begin{array}{l}\text { 3) The vehicle I regularly drive was } \\
\text { damaged in the accident. but i was } \\
\text { stitl able to drive the vehicle. }\end{array}$ & 14 & 6 & 11 & 25 & 6 & 31 \\
\hline Column Percent & 26.4 & 17.6 & 19.3 & 38.5 & 7.6 & 21.5 \\
\hline $\begin{array}{l}\text { 4) Wy vehicle was damaged in the } \\
\text { accident such that I could not drive } \\
\text { it away from the accident scene, but } \\
\text { it has been repaired. }\end{array}$ & 5 & 5 & 13 & 11 & 12 & 23 \\
\hline Column Percent & 9.4 & 14.7 & 22.8 & 16.9 & 15.2 & 16.0 \\
\hline $\begin{array}{l}\text { 5) My vehicle was damaged in the } \\
\text { accident such that i could not drive } \\
\text { it away from the accident scene, and } \\
\text { it has not been repaired. }\end{array}$ & 20 & 18 & 22 & 16 & 44 & 60 \\
\hline Column Percent & 37.7 & 52.9 & 38.6 & 24.6 & 55.7 & 41.7 \\
\hline Total & 53 & 34 & 57 & 65 & 79 & 144 \\
\hline
\end{tabular}


07C) WHICH OF THE FOLLGUING BEST DESCRIBES THE TYPE OF WORK YOU DO AT YOUR CURRENT JOB?

\begin{tabular}{|c|c|c|c|c|c|c|c|}
\hline & & \multicolumn{3}{|c|}{ State of Accident } & \multicolumn{2}{|c|}{ Treatment of Injuries } & \multirow[b]{2}{*}{ Total } \\
\hline & & Pennsylvania & Cal ifornia & Delaware & $\begin{array}{l}\text { Not treated } \\
\text { at hospital }\end{array}$ & $\begin{array}{c}\text { Treated at } \\
\text { hospital }\end{array}$ & \\
\hline \multicolumn{2}{|l|}{ RESPONSE } & & & & & & \\
\hline \multirow[t]{2}{*}{ 1) Professional } & & 19 & 6 & 13 & 20 & 18 & 38 \\
\hline & Column Percent & 36.5 & 20.0 & 22.4 & 30.8 & 24.0 & 27.1 \\
\hline \multirow[t]{2}{*}{ 2) Technical } & & 4 & 1 & 5 & 6 & 4 & 10 \\
\hline & Col umn Percent & 7.7 & 3.3 & 8.6 & 9.2 & 5.3 & 7.1 \\
\hline \multirow[t]{2}{*}{ 3) Managerial } & & 8 & 3 & 4 & 10 & 5 & 15 \\
\hline & Column Percent & 15.4 & 10.0 & 6.9 & 15.4 & 6.7 & 10.7 \\
\hline \multicolumn{2}{|c|}{ 4) Sales: High-Level } & 3 & 3 & 5 & 1 & 10 & 11 \\
\hline & Column Percent & 5.8 & 10.0 & 8.6 & 1.5 & 13.3 & 7.9 \\
\hline \multicolumn{2}{|l|}{ 5) Sales: Clerical } & 1 & -- & 3 & 1 & 3 & 4 \\
\hline & Column Percent & 1.9 & -- & 5.2 & 1.5 & 4.0 & 2.9 \\
\hline \multicolumn{2}{|c|}{ 6) Mon-Sales: Clerical } & 1 & 1 & 4 & 2 & 4 & 6 \\
\hline & Column Percent & 1.9 & 3.3 & 6.9 & 3.1 & 5.3 & 4.3 \\
\hline \multicolumn{2}{|c|}{ 7) Service (e.g., food service) } & 4 & 7 & 5 & 5 & 11 & 16 \\
\hline & Column Percent & 7.7 & 23.3 & 8.6 & 7.7 & 14.7 & 11.4 \\
\hline \multicolumn{2}{|c|}{ 8) Craft/skilled worker } & 3 & $3]$ & 4 & 3 & 7 & 10 \\
\hline & Column Percent & 5.8 & 10.0 & 6.9 & 4.6 & 9.3 & 7.1 \\
\hline \multicolumn{2}{|l|}{ 9) Machine operator } & $\cdots$ & 1 & $\cdots$ & 1 & $\cdots$ & 1 \\
\hline & Column Percent & $\cdots$ & 3.3 & -- & 1.5 & $\cdots$ & 0.7 \\
\hline \multicolumn{2}{|c|}{ 10) Professional driver } & 2 & -- & 1 & 3 & -- & 3 \\
\hline & Column Percent & 3.8 & --1 & 1.7 & 4.6 & -- & 2.1 \\
\hline \multirow[t]{2}{*}{ 11) Laborer } & & 2 & 1 & -- & 1 & 2 & 3 \\
\hline & Column Percent & 3.8 & 3.3 & -- & 1.5 & 2.7 & 2.1 \\
\hline \multirow[t]{2}{*}{ 13) No Employment } & $1993 / 1994 / 1995$ & 5 & 4 & 14 & 12 & 11 & 23 \\
\hline & Column Percent & 9.6 & 13.3 & 24.1 & 18.5 & 14.7 & 16.4 \\
\hline \multicolumn{2}{|l|}{ Total } & 52 & 30 & 58 & 65 & 75 & 140 \\
\hline
\end{tabular}


Effects of Adninistrative License Revocation on Employment O7F) IF IF YOU ARE NOT STILL WOKKING AT THIS JOB, HAY DID YOU LEAVE?

\begin{tabular}{|c|c|c|c|c|c|c|c|}
\hline & & \multicolumn{3}{|c|}{ State of Accident } & \multicolumn{2}{|c|}{ Treatment of Injuries } & \multirow{2}{*}{ Total } \\
\hline & & Pennsylvania & California & Delaware & $\begin{array}{l}\text { Not treated } \\
\text { et hospital }\end{array}$ & $\begin{array}{l}\text { Treated at } \\
\text { hospital }\end{array}$ & \\
\hline \multicolumn{2}{|l|}{ RESPONSE } & & & & & & \\
\hline \multicolumn{2}{|l|}{ 1) Better opportunity } & $\cdots$ & 1 & $\cdots$ & $\cdots$ & 1 & 1 \\
\hline & Column Percent & $\cdots$ & 20.0 & -- & $\cdots$ & 7.1 & 5.9 \\
\hline \multicolumn{2}{|l|}{ 2) Layoff/termination } & $\cdots$ & 2 & 1 & 1 & 2 & 3 \\
\hline & Column Percent & $\cdots$ & 40.0 & 14.3 & 33.3 & 14.3 & 17.6 \\
\hline \multicolumn{2}{|l|}{ 3) Medical/disability } & 2 & 2 & 2 & $\cdots$ & 6 & 6 \\
\hline & Col umn Percent & 40.0 & 40.0 & 28.6 & -- & 42.9 & 35.3 \\
\hline \multicolumn{2}{|c|}{$\begin{array}{l}\text { 5) Resignation/unsat is factory job } \\
\text { conditions }\end{array}$} & 2 & -- & $\cdots$ & 1 & $1)$ & 2 \\
\hline & Column Percent & 40.0 & $\cdots$ & -- & 33.3 & 7.1 & 11.8 \\
\hline \multicolumn{2}{|l|}{ 6) Return to school } & 1 & $\cdots$ & 4 & 1 & 4 & 5 \\
\hline & Column Percent & 20.0 & -- & 57.1 & 33.3 & 28.6 & 29.4 \\
\hline \multicolumn{2}{|l|}{ Total } & 5 & 5 & 7 & 3 & 14 & 17 \\
\hline
\end{tabular}


Q8C) WHICH OF THE Frequency Tables by State Treatment at Hospital, and Total

\begin{tabular}{|c|c|c|c|c|c|c|c|}
\hline & & \multicolumn{3}{|c|}{ State of Accident } & \multicolumn{2}{|c|}{ Treatment of Injuries } & \multirow[b]{2}{*}{ Total } \\
\hline & & \begin{tabular}{|l|} 
Pennsylvania \\
\end{tabular} & California & Delaware & $\begin{array}{l}\text { Not treated } \\
\text { at hospital }\end{array}$ & $\begin{array}{c}\text { Treated at } \\
\text { hospital }\end{array}$ & \\
\hline \multicolumn{2}{|l|}{ RESPONSE } & & & & & & \\
\hline \multirow[t]{2}{*}{ 1) Professional } & & 1 & $\cdots$ & 2 & 1 & 2 & 3 \\
\hline & Column Percent & 12.5 & -- & 12.5 & 11.1 & 11.8 & 11.5 \\
\hline \multirow[t]{2}{*}{ 3) Managerial } & & 2 & $\cdots$ & 2 & -- & 4 & 4 \\
\hline & Column Percent & 25.0 & $\cdots$ & 12.5 & -- & 23.5 & 15.4 \\
\hline \multicolumn{2}{|l|}{ 4) Sales: High-Level } & 1 & $\cdots$ & 4 & 1 & 4 & 5 \\
\hline & Column Percent & 12.5 & $\cdots$ & 25.0 & 11.1 & 23.5 & 19.2 \\
\hline \multicolumn{2}{|l|}{ 5) Sales: Clerical } & $\cdots$ & $\cdots$ & 1 & $\cdots$ & 1 & 1 \\
\hline & Column Percent & $\cdots$ & $\cdots$ & 6.3 & $\cdots$ & 5.9 & 3.8 \\
\hline \multirow[t]{2}{*}{ 7) Service (e.g., } & food service) & 2 & 2 & 3 & 4 & 3 & 7 \\
\hline & Column Percent & 25.0 & 100.0 & 18.8 & 44.4 & 17.6 & 26.9 \\
\hline \multicolumn{2}{|c|}{ 8) Craft/skilled worker } & $\cdots$ & $\cdots$ & 1 & $\cdots$ & 1 & 1 \\
\hline & Column Percent & -- & $\cdots$ & 6.3 & $\cdots$ & 5.9 & 3.8 \\
\hline \multicolumn{2}{|c|}{ 10) Professional driver } & 2 & $\cdots$ & 2 & 3 & 1 & 4 \\
\hline & Column Percent & 25.0 & $\cdots$ & 12.5 & 33.3 & 5.9 & 15.4 \\
\hline \multirow[t]{2}{*}{ 11) Laborer } & & $\cdots$ & $\cdots$ & 1 & $\cdots$ & 1 & 1 \\
\hline & Column Percent & -- & $\cdots$ & 6.3 & $\cdots$ & 5.9 & 3.8 \\
\hline \multicolumn{2}{|l|}{ Total } & 8 & 2 & 16 & 9 & 17 & 26 \\
\hline
\end{tabular}


Effects of Administrative License Reyocation on Employment

Q8F) If YOU YOU ARE NOT SYILL WORKING AT THIS JOB, WHY BID YOU LEAVE?

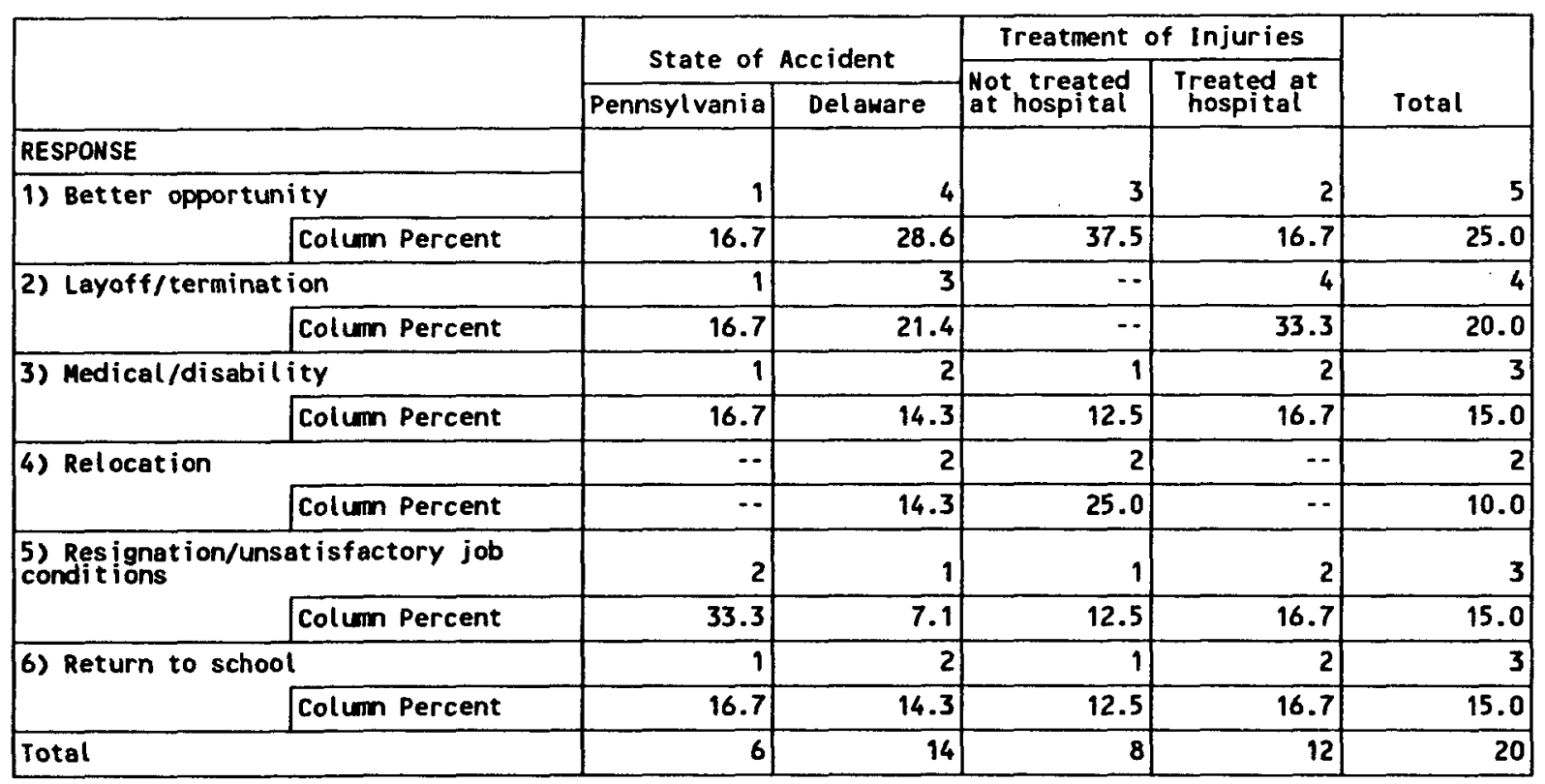


Effects of Administrative License Revocation on Employment

Ereguency Tables by State Treeatment at Hospital and Total
Q9) WERE YOU EMPLOYED XT THE TIME OF. YOUR ALCOHbL-RELATED ACCIDENT?

\begin{tabular}{|c|c|c|c|c|c|c|c|}
\hline & & \multicolumn{3}{|c|}{ State of Accident } & \multicolumn{2}{|c|}{ Treatment of Injuries } & \multirow[b]{2}{*}{ Total } \\
\hline & & \begin{tabular}{|l|} 
Pennsylvania \\
\end{tabular} & California & Delaware & $\begin{array}{l}\text { Not treated } \\
\text { at hospital }\end{array}$ & $\begin{array}{c}\text { Treated at } \\
\text { hospital }\end{array}$ & \\
\hline \multicolumn{2}{|c|}{ RESPONSE } & \multirow[b]{2}{*}{49} & \multirow[b]{2}{*}{26} & \multirow[b]{2}{*}{43} & \multirow[b]{2}{*}{54} & \multirow[b]{2}{*}{64} & \multirow[b]{2}{*}{118} \\
\hline Yes & & & & & & & \\
\hline & Column Percent & 90.7 & 76.5 & 74.1 & 81.8 & 80.0 & 80.8 \\
\hline \multirow[t]{2}{*}{ No } & & 5 & 8 & 15 & 12 & 16 & 28 \\
\hline & Column Percent & 9.3 & 23.5 & 25.9 & 18.2 & 20.0 & 19.2 \\
\hline \multicolumn{2}{|c|}{ Total } & 54 & 34 & 58 & 66 & 80 & 146 \\
\hline
\end{tabular}

The Difference Between this The Total Sample Size for these Reports is 146 Victims (54 in PA; 34 in CA; and 58 in $D E$ ). 
Q11) IN HHICH OF THE FOLLOWING EFHNIC GROUPS HOULD YOU CLASSIFY YOURSELF?

\begin{tabular}{|c|c|c|c|c|c|c|}
\hline & \multicolumn{3}{|c|}{ State of Accident } & \multicolumn{2}{|c|}{ Treatment of Injuries } & \multirow[b]{2}{*}{ Total } \\
\hline & \begin{tabular}{|l|} 
Pennsylvania \\
\end{tabular} & California & Delanare & $\begin{array}{l}\text { Not treated } \\
\text { at hospital }\end{array}$ & $\begin{array}{l}\text { Treated at } \\
\text { hospital }\end{array}$ & \\
\hline RESPONSE & \multirow[b]{2}{*}{46} & \multirow[b]{2}{*}{27} & \multirow[b]{2}{*}{47} & \multirow[b]{2}{*}{53} & \multirow[b]{2}{*}{67} & \multirow[b]{2}{*}{120} \\
\hline White, not of Hispanic origin & & & & & & \\
\hline Column Percent & 90.2 & 79.4 & 82.5 & 82.8 & 85.9 & 84.5 \\
\hline other & 5 & 7 & 10 & 11 & 11 & 22 \\
\hline Column Percent & 9.8 & 20.6 & 17.5 & 17.2 & 14.1 & 15.5 \\
\hline Total & 51 & 34 & 57 & 64 & 78 & 142 \\
\hline
\end{tabular}


Effects of Administrative License Revocation on Employment

Frequency Tables by State Treatment at Hospital, and Total

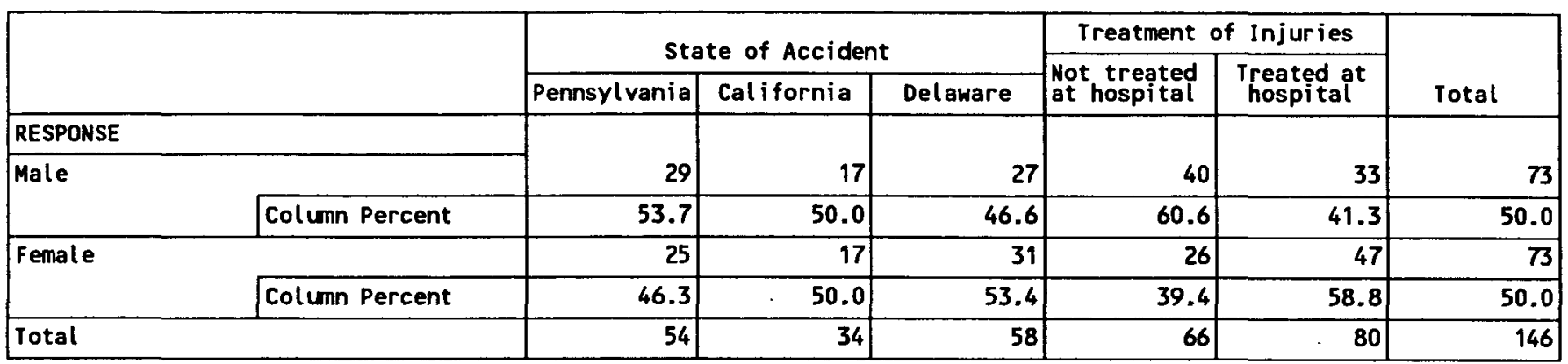


Q14) WHAT WAS YOUR HIGHEST LEVEL OF EDUCA ION AT THE TIME OF YOUR ALCOHOL-RELATED ACCIDENT?

\begin{tabular}{|c|c|c|c|c|c|c|}
\hline & \multicolumn{3}{|c|}{ State of Accident } & \multicolumn{2}{|c|}{ Treatment of Injuries } & \multirow[b]{2}{*}{ Total } \\
\hline & Pennsylvania & Cal ifornia & Del aware & $\begin{array}{l}\text { Not treated } \\
\text { at hospital }\end{array}$ & $\begin{array}{l}\text { Treated at } \\
\text { hospital }\end{array}$ & \\
\hline RESPONSE & & & & & & \\
\hline 1) Junior high school (or less) & 1 & 2 & $\cdots$ & -- & 3 & 3 \\
\hline Column Percent & 1.9 & 6.1 & -- & -- & 3.8 & 2.1 \\
\hline 2) Some high school & 5 & 4 & 5 & 6 & 8 & 14 \\
\hline Column Percent & 9.6 & 12.1 & 8.6 & 9.4 & 10.1 & 9.8 \\
\hline 3) High school graduate & 11 & 2 & 13 & 9 & 17 & 26 \\
\hline Column Percent & 21.2 & 6.1 & 22.4 & 14.1 & 21.5 & 18.2 \\
\hline 4) Trade school certificate & 3 & 3 & 6 & 4 & 8 & 12 \\
\hline Column Percent & 5.8 & 9.1 & 10.3 & 6.3 & 10.1 & 8.4 \\
\hline 5) Some coll ege, but no degree & 7 & 8 & 14 & 12 & 17 & 29 \\
\hline Column Percent & 13.5 & 24.2 & 24.1 & 18.8 & 21.5 & 20.3 \\
\hline 6) Associates or 2-year college degree & 3 & 6 & 5 & 10 & 4 & 14 \\
\hline Column Percent & 5.8 & 18.2 & 8.6 & 15.6 & 5.1 & 9.8 \\
\hline 7) Bachelors or 4 -year college degree & 14 & 5 & 11 & 13 & 17 & 30 \\
\hline Column Percent & 26.9 & 15.2 & 19.0 & 20.3 & 21.5 & 21.0 \\
\hline 8) Masters or doctorate degree & 8 & 3 & 4 & 10 & 5 & 15 \\
\hline Column Percent & 15.4 & 9.1 & 6.9 & 15.6 & 6.3 & 10.5 \\
\hline Total & 52 & 33 & 58 & 64 & 79 & 143 \\
\hline
\end{tabular}


Effects of Administrative License Revocation on Employment

Q15) WHAT WAS YOUR MARITAL SYATUS AT THE TIME OF YOUR ALCOHOL-RELATED ACCIDENT?

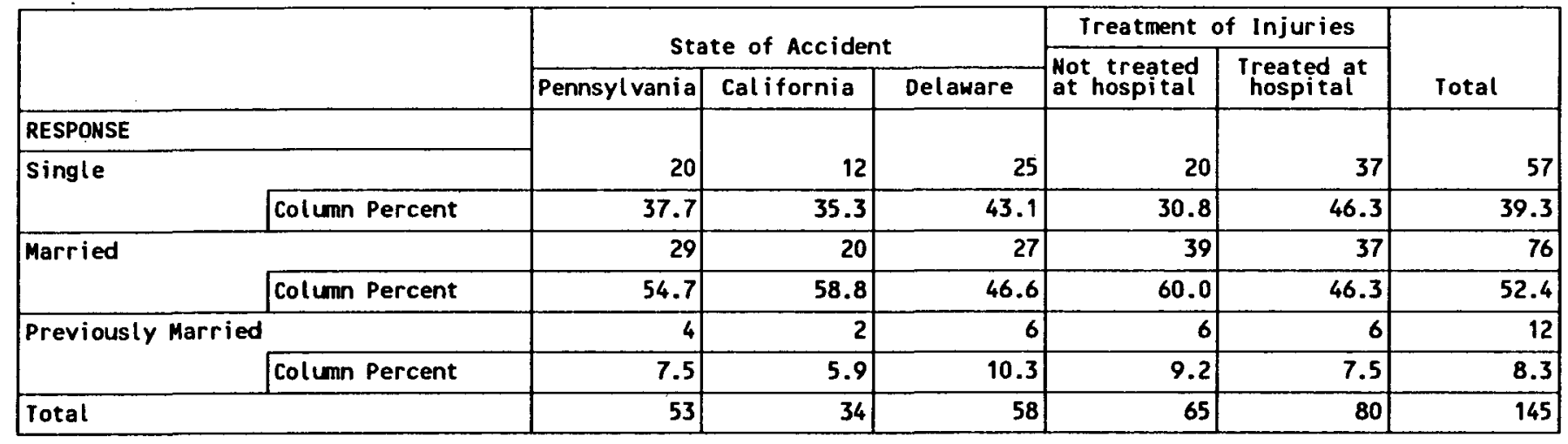


Effects of Administrative License Revocation on Employment

Tabul ation by State, Ireatment at Hospital and Total
Average Value and Frequency Count for Cont inuous Variables

\begin{tabular}{|c|c|c|c|c|c|c|c|}
\hline & & \multicolumn{3}{|c|}{ State of Accident } & \multicolumn{2}{|c|}{ Ireatment of Injuries } & \multirow[b]{2}{*}{ Total } \\
\hline & & \begin{tabular}{|l} 
Pennsylvania \\
\end{tabular} & Cal ifornia & Delaware & $\begin{array}{l}\text { Not treated } \\
\text { at hospital }\end{array}$ & $\begin{array}{c}\text { Treated at } \\
\text { hospital }\end{array}$ & \\
\hline \multirow{2}{*}{$\begin{array}{l}\text { Months from DUI } \\
\text { acc ident to } \\
\text { interview }\end{array}$} & Average Value & 17.91 & 15.21 & 15.34 & 15.64 & 16.78 & 16.26 \\
\hline & Frequency Count & 54 & 34 & 58 & 66 & 80 & 146 \\
\hline \multirow{2}{*}{$\begin{array}{l}\text { 06) Number of } \\
\text { months ansurd in } \\
\text { calendar }\end{array}$} & Average value & 26.50 & 23.65 & 23.55 & 24.61 & 24.71 & 24.66 \\
\hline & Frequency Count & 54 & 34 & 58 & 66 & 80 & 146 \\
\hline \multirow{2}{*}{$\begin{array}{l}\text { Q6) Number of } \\
\text { months wi th } \\
\text { empl oyment }\end{array}$} & Average Value & 21.56 & 17.03 & 15.24 & 19.53 & 16.73 & 17.99 \\
\hline & Frequency Count & 54 & 34 & 58 & 66 & 80 & 146 \\
\hline \multirow{2}{*}{$\begin{array}{l}\text { 06) Number of } \\
\text { months at tending } \\
\text { school }\end{array}$} & Average Value & 2.54 & 1.94 & 4.47 & 2.15 & 4.00 & 3.16 \\
\hline & Frequency Count & 54 & 34 & 58 & 66 & 80 & 146 \\
\hline \multirow{2}{*}{$\begin{array}{l}\text { Q6) Months } \\
\text { unemply/search ing } \\
\text { for work }\end{array}$} & Average Value & 0.50 & 0.68 & 0.16 & 0.30 & 0.49 & 0.40 \\
\hline & Frequency Count & 54 & 34 & 58 & 66 & 80 & 146 \\
\hline \multirow{2}{*}{$\begin{array}{l}\text { Q6) Months } \\
\text { unemply/not } \\
\text { searchng for work }\end{array}$} & Average Value & 1.41 & 1.00 & 1.53 & 1.62 & 1.15 & 1.36 \\
\hline & Frequency Count & 54 & 34 & 58 & 66 & 80 & 146 \\
\hline \multirow{2}{*}{$\begin{array}{l}\text { 06) Number of } \\
\text { months di sabil ity }\end{array}$} & Average Value & 1.26 & 2.50 & 2.21 & 0.77 & 2.88 & 1.92 \\
\hline & Frequency Count & 54 & 34 & 58 & 66 & 80 & 146 \\
\hline \multirow{2}{*}{$\begin{array}{l}\text { 06) Humber of } \\
\text { months ret irement }\end{array}$} & Average Value & 0.52 & 1.41 & 2.10 & 1.89 & 0.91 & 1.36 \\
\hline & Frequency Count & 54 & 34 & 58 & 66 & 80 & 146 \\
\hline \multirow{2}{*}{$\begin{array}{l}\text { Tenure in months } \\
\text { at current job }\end{array}$} & Average Value & 83.67 & 66.28 & 64.13 & 81.54 & 65.01 & 72.33 \\
\hline & Frequency Count & 48 & 29 & 45 & 54 & 68 & 122 \\
\hline \multirow{2}{*}{$\begin{array}{l}\text { a7d)Weekly hours } \\
\text { worked/current job }\end{array}$} & Average Value & 39.07 & 36.19 & 38.60 & 42.12 & 35.09 & 38.24 \\
\hline & Frequency count & 45 & 26 & 45 & 52 & 64 & 116 \\
\hline \multirow{2}{*}{$\begin{array}{l}\text { a7e) Weekly gross } \\
\text { earnings/current } \\
\text { job }\end{array}$} & Average Value & 737.43 & 676.00 & 608.84 & 836.30 & 539.46 & 669.50 \\
\hline & Frequency Count & 37 & 24 & 44 & 46 & 59 & 105 \\
\hline \multirow{2}{*}{$\begin{array}{l}\text { Tenure in months } \\
\text { (next most recent } \\
\text { job) }\end{array}$} & Average Value & 15.63 & 37.00 & 52.00 & 45.67 & 36.47 & 39.65 \\
\hline & Frequency Count & 8 & 2 & 16 & 9 & 17 & 26 \\
\hline \multirow{2}{*}{$\begin{array}{l}\text { 08d)Weekly hours } \\
\text { worked/next job }\end{array}$} & Average Value & 32.13 & 14.50 & 34.06 & 32.78 & 31.53 & 31.96 \\
\hline & Frequency Count & 8 & 2 & 16 & 9 & 17 & 26 \\
\hline \multirow{2}{*}{$\begin{array}{l}\text { abe)Weekly grosss } \\
\text { earnings/next job }\end{array}$} & Average Value & 285.50 & 125.00 & 322.88 & 317.22 & 285.00 & 296.15 \\
\hline & Frequency Count & 8 & 2 & 16 & 9 & 17 & 26 \\
\hline
\end{tabular}

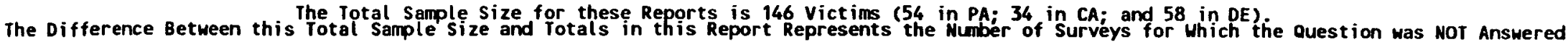


Effects of Administrative License Revocation on Employment

Victim Quest $i$ onnaire

Tabulation by State, Ireatment at Hospital, and Total
Average Value and Frequency Count for Cont inuous Variables

\begin{tabular}{|c|c|c|c|c|c|c|c|}
\hline & & \multicolumn{3}{|c|}{ State of Accident } & \multicolumn{2}{|c|}{ Treatment of Injuries } & \multirow[b]{2}{*}{ Total } \\
\hline & & Pennsylvania & California & Delaware & $\begin{array}{l}\text { Not treated } \\
\text { at hospital }\end{array}$ & $\begin{array}{c}\text { Treated at } \\
\text { hospital }\end{array}$ & \\
\hline \multirow{2}{*}{$\begin{array}{l}\text { Q10a)Total } \\
\text { uncompensated lost } \\
\text { work time }\end{array}$} & Average Value & 576.36 & 1367.86 & 488.50 & 295.41 & 1088.26 & 681.93 \\
\hline & Frequency Count & 36 & 14 & 30 & 41 & 39 & 80 \\
\hline \multirow{2}{*}{$\begin{array}{l}\text { a10b)o iff btw reg } \\
\text { pay and disab pay }\end{array}$} & Average Value & 236.58 & 37.50 & 92.48 & 0.85 & 285.17 & 150.49 \\
\hline & Frequency Count & 26 & 8 & 23 & 27 & 30 & 57 \\
\hline \multirow{2}{*}{$\begin{array}{l}\text { 010c)Amount/uk in } \\
\text { reduced income }\end{array}$} & Average Value & 61.24 & 168.33 & 107.23 & 60.00 & 130.00 & 98.89 \\
\hline & Frequency Count & 29 & 12 & 31 & 32 & 40 & 72 \\
\hline \multirow[t]{2}{*}{ Age at interview } & Average Value & 37.06 & 37.15 & 38.05 & 39.98 & 35.46 & 37.47 \\
\hline & Frequency Count & 53 & 34 & 57 & 64 & 80 & 144 \\
\hline \multirow{2}{*}{$\begin{array}{l}\text { Age at alcohol- } \\
\text { related accident }\end{array}$} & Average Value & 35.68 & 35.82 & 36.81 & 38.77 & 34.08 & 36.16 \\
\hline & Frequency Count & 53 & 34 & 57 & 64 & 80 & 144 \\
\hline
\end{tabular}




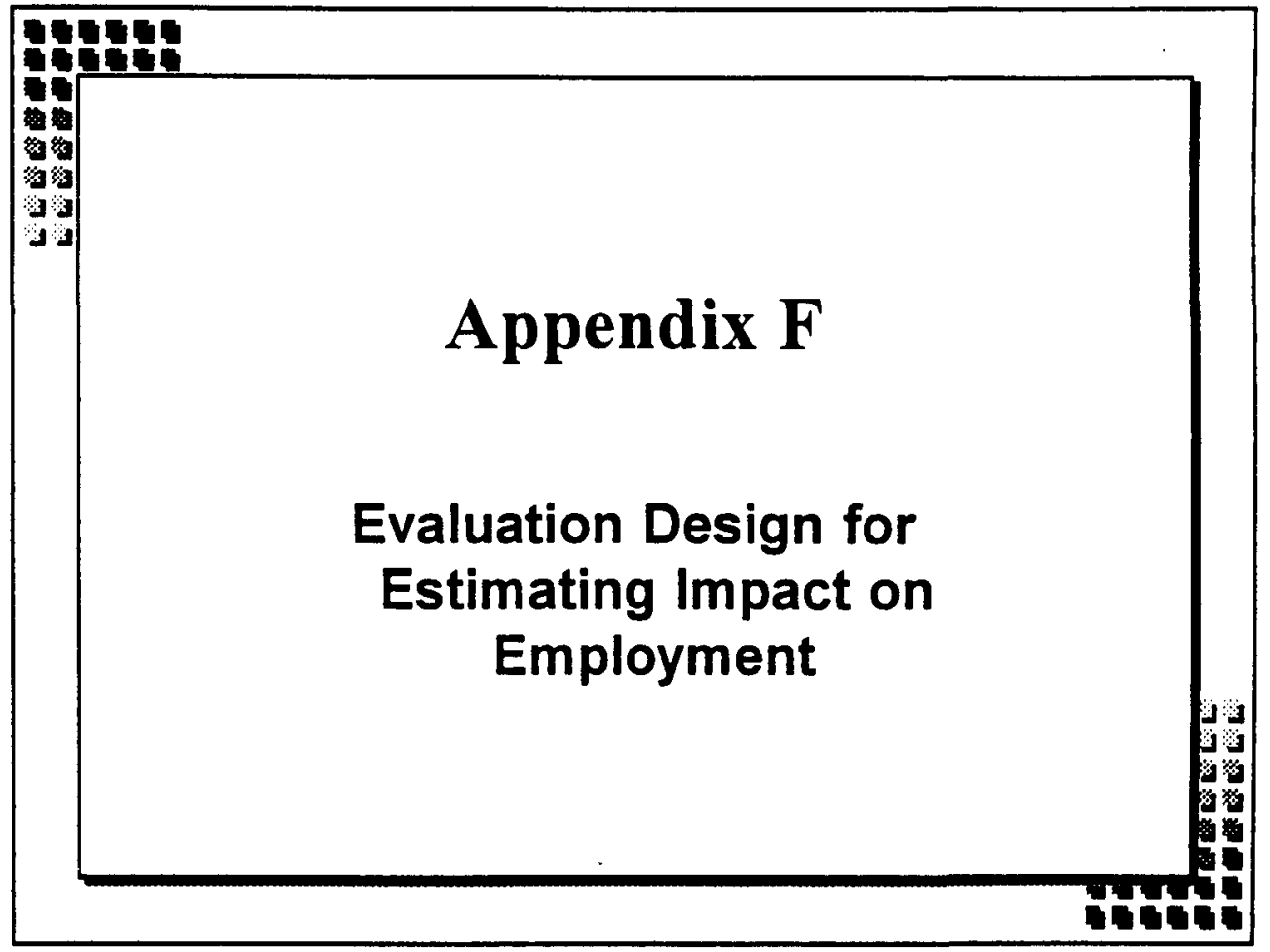




\section{Appendix $F$ \\ Evaluation Design for Estimating Impact on Employment}

The classic pretest, posttest, control group quasi-experimental design was employed for estimating the impact on employment of the ALR sanction. This design is initially set up with two equivalent groups which are as alike as possible before the intervention (ALR sanction). Such equivalence is best obtained by random assignment to experimental and control groups. However, random assignment is not a practical approach for the evaluation of the ALR sanction process. These broad-based programs do not target specific individuals and, hence, waivers to the law in order to run an experiment would be required.

Where random assignment is not administratively feasible, selective matching must be used. The process may involve matched comparison sites or matched comparison groups of specific individuals. A "before" measure is made to determine the baseline from which change is to be evaluated, and for providing a check on the equivalence of the two groups. One of the groups (the treatment group) is exposed to the intervention being evaluated while the other (the control group) is not. At the conclusion of the intervention (or at appropriate time intervals), an "after" measure is made which may be compared with the "before" measure for both treatment and control groups to indicate the changes produced by the intervention.

In place of the random assignment feature, another jurisdiction (Pennsylvania, a non-ALR state) was selected to be used as a comparison against which the effects of the ALR sanction process were measured. An illustration of how the intervention effect is measured with this design is given as:

Treatment Area

Matched Comparison Area

\begin{tabular}{|c|c|}
\multicolumn{1}{c}{ Before } & After \\
\hline$T_{1}$ & $T_{2}$ \\
\hline$C_{1}$ & $C_{2}$ \\
\hline
\end{tabular}

$d_{T}=T_{2}-T_{1}$

$d_{c}=C_{2}-C_{1}$

The test of ALR sanction effect is based on the difference between $d_{T}$ and $d_{c}$. Under ideal conditions, there is no element of fallibility in this design. Whatever differences are observed between the treatment and matched comparison groups must be attributable to the intervention being evaluated.

One extension of this design (pretest, posttest, experimental and control group) would help to determine the extent to which the effectiveness of an intervention was related to specific components of that intervention rather than to the existence of the intervention per se. This would involve the addition of alternative interventions varying combinations of specific components for comparative evaluation. Using the variation of the pretest, posttest, control group design as described above, this design is illustrated as follows: 


\begin{tabular}{ll|}
\hline Intervention Level 1: & $0_{1} X_{1} O_{2}$ \\
Intervention Level 2: & $O_{3} X_{2} O_{4}$ \\
Intervention Level 3: & $O_{5} X_{3} O_{6}$ \\
Control: & $0_{7} O_{8}$ \\
\hline
\end{tabular}

where 0 represents periods of observation and $X$ represents periods of intervention.

This design is especially effective for evaluating ALR sanction levels when intervention variations $X_{1}, X_{2}$, and $X_{3}$ consist of successively higher levels of ALR sanction. This is the design that was implemented in this evaluation. Each state represented a different level of ALR sanction. Maryland, California, and Delaware represented progressively higher levels of ALR sanction and Pennsylvania, with no ALR sanction, provided DUI offenders who were used as the control group.

Even with an attempt to develop matched project sites and matched samples of DUI offenders, it cannot be certain that all groups are equivalent with respect to all important factors. Therefore, multivariate models were specified to provide estimates of ALR sanction impact over time.

The following discusses the estimation procedures that were used in the analysis of the effect of ALR sanctions on the employment patterns of DUI offenders and victims. However, before discussing the methodology, a brief overview of the situation is presented. Observations were made of DUI offender employment patterns from four states in three time periods: (1) before the key DUI arrest event (pre-period); (2) immediately after the key DUI event (ALR sanction period or intervention period); and (3) after the ALR sanction period was complete (post-period). ${ }^{1}$ Three states provided observations of DUI offenders exposed to progressively higher levels of ALR sanction. One state (Pennsylvania) provided observations of DUI offenders who were not exposed to ALR sanctions and who did not have their license suspended immediately after the DUI arrest event. The hypothesis is that exposure to the ALR sanction has no significant effect on the employment patterns for DUI offenders (hours worked or eamings). A simplified representation of this situation, displaying only one treatment group and the control group, is depicted in Figure F-1.

1 From some DUI offenders, there may not have been an observation in the third time period. That is, at the time of the interview, some DUI offenders were still under license suspension/revocation when they attended the DUI school (i.e., time of interview). Since the multivariate analysis estimates ALR sanction impact by month, this was not a problem. 


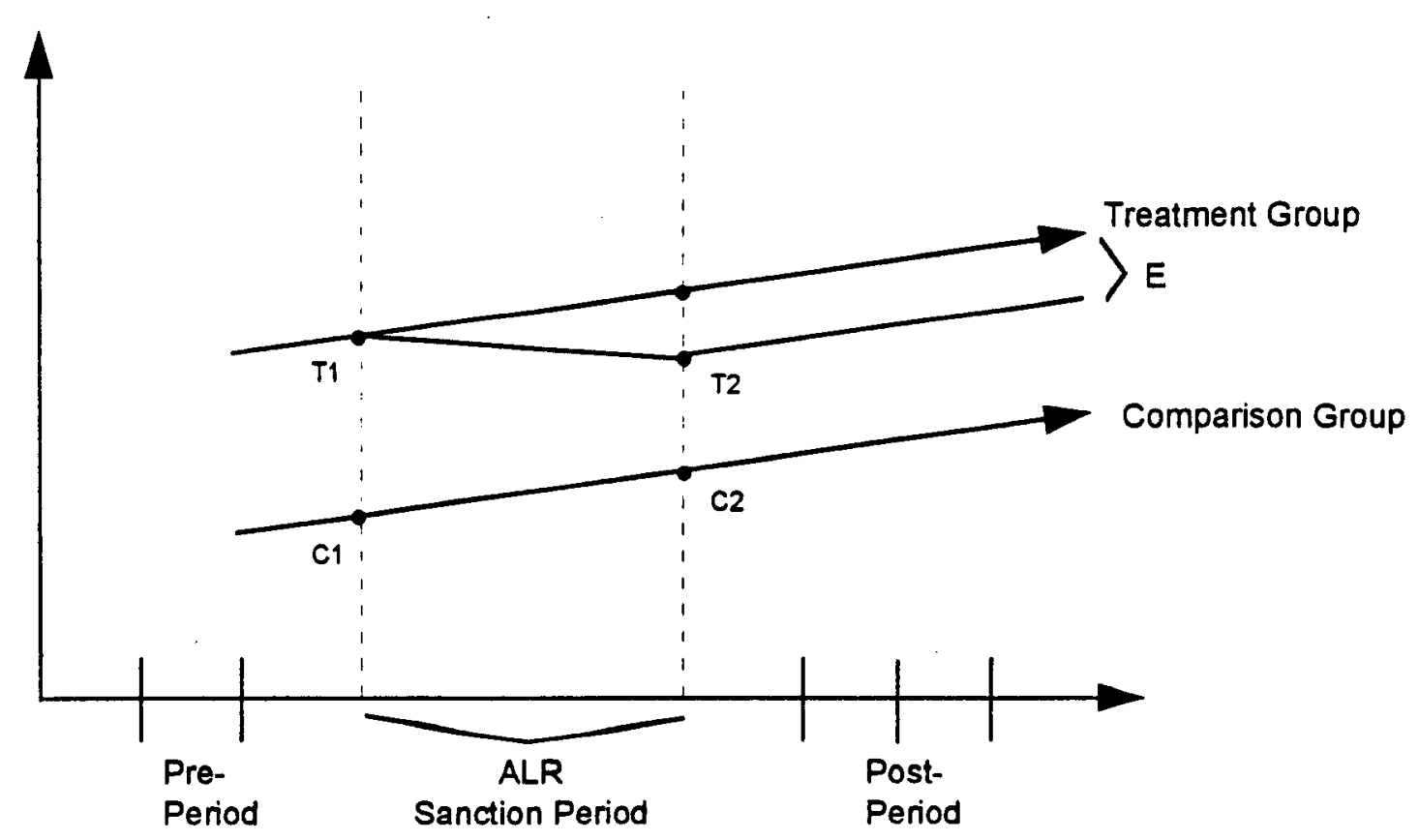

Figure F-1. Representation of ALR Sanction Effects

The figure depicts an increase in earnings without exposure to the ALR sanction process (indicated by the upward sloping lines), a difference in the "normal" eamings between the treatment group and comparison group (indicated by the separate line segments for each group in the pre-period), and a decrease in earnings due to exposure to the ALR sanction process (represented by E). Moreover, the figure depicts a situation in which earnings are permanently changed by exposure to the intervention and neither decay nor build up after exposure.

The estimate of effect in this simple example is $E=\left(T_{2}-T_{1}\right)-\left(C_{2}-C_{1}\right)$. If the earnings for the treatment and comparison groups are similar (something expected from matched samples), then $T_{1}=C_{1}$ and, hence, $E=T_{2}-C_{2}$. The methodology controls for the difference between treatment and comparison groups (both differences in demographics and behavior in the pre-period) and estimates an unbiased effect of intervention activity on earnings. The null hypothesis for DUl offenders is that $E=0$ against the alternative that $E$ $<0$.

To discuss the logic of the empirical approach that was used to estimate the effect of the ALR sanctions, an equation can be written for offenders using analysis of variance notation and terminology. Letting the index $i$ denote an individual driver in the sample and the index $j$ denote the period of observation, the equation is:

$$
Y_{i j}=\mu+\alpha_{i}+\beta_{j}+\gamma_{i j}+\varepsilon_{i j} \quad(i=1, \ldots, i ; j=1, \ldots, J) \text {, where: }
$$


$Y_{i j}=$ earnings of the ith individual in period $j$ (where $j$ is a month)

$\mu=$ the grand mean

$\alpha_{i}=$ the effect due to the ith category or level of the time-invariant factor (e.g., the effect of the driver's sex)

$\beta_{j}=$ the effect due to the jth category or level of the time-varying factor (e.g., driver age in period $\mathrm{j}$ )

$\gamma_{i j}=$ the ALR sanction effect for driver $i$ in period $j$ (assumed to be zero in all periods for comparison group drivers)

$\varepsilon_{i j}=$ the (assumed) stochastic effect of omitted variables and measurement error

In parameterizing this model, the impact effects $\left(\gamma_{i j}\right)$ are represented by a series of binary variables that distinguish drivers in the treatment group in each post-period, that is, a set of binary variables that represents the interaction of treatment/comparison status with each period. The treatment event for DUI offenders was the DUI arrest event.

Multivariate statistical techniques were used to examine the relationships between two dependent variables (earnings and hours worked) and a set of explanatory variables (e.g., age, gender, alcohol abuse, and level of ALR sanction). The model estimated the effect or relationship of level of ALR sanction on several dependent variables, while controlling for other explanatory variables.

Multivariate statistical techniques offer a way to control for differences between treatment and comparison groups that could bias the estimate of impact. Multivariate estimation methods have a number of advantages over univariate methods. Systematic differences between samples can be controlled for by explicitly including the variables in the model. Also, by controlling for other factors, multivariate models explain more of the variation in the outcome variable and detect significant differences that cannot be detected in a univariate model. Multivariate estimation methods require specification of a functional form of the model. For the ALR sample of DUI offenders, a simple impact model can be written as:

$$
Y_{n t}=a+\sum_{j=1}^{J} b_{j} X_{n j}+\sum_{k=1}^{K} c_{k} Z_{n k}+\sum_{l=1}^{L} d_{l} I_{n t l} \quad \mathrm{t}=1,2 ; \text { and } \mathrm{n}=1,2, \ldots, \mathrm{N}
$$

where $t$ is a subscript for time ( 1 is pre-ALR sanction and 2 is post-ALR sanction), $n$ is a subscript for DUI offenders, $Y_{\text {nt }}$ is the outcome variable being modeled (earnings and hours worked), $X_{n+1}$ are time-varying DUl-offender characteristics, $Z_{n k}$ are time-invariant DUIoffender characteristics, and $I_{\mathrm{nt}}$ are the impact variables (equal to 1 for DUI offenders under 
ALR sanction in the post-DUI arrest period and 0 otherwise). Impact variables were defined as follows:

$I_{\text {nt }}=1$ if the DUI ALR sanction is in Maryland and $t$ represents the post-ALR sanction period; 0 otherwise.

$I_{\text {nt }}=1$ if the DUI ALR sanction is in California and $t$ represents the post-ALR sanction period; 0 otherwise.

$I_{\mathrm{n} i \mathrm{~s}}=1$ if the DUI ALR sanction is in Delaware and $t$ represents the post-ALR sanction period; 0 othenwise.

Thus, if $I_{n t 1}=I_{n t 2}=I_{n+3}=0$, the respondent was from Pennsylvania or $t$ represented the preALR sanction period. The model parameters, $a, b_{j}, c_{k}$, and $d_{1}$, were estimated using Ordinary Least Squares (OLS) regression. 
DOT HS 808462

May 1996

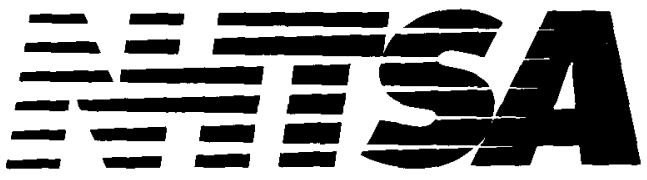

People Saving People

httb://www.nhtsa.dot.gov 